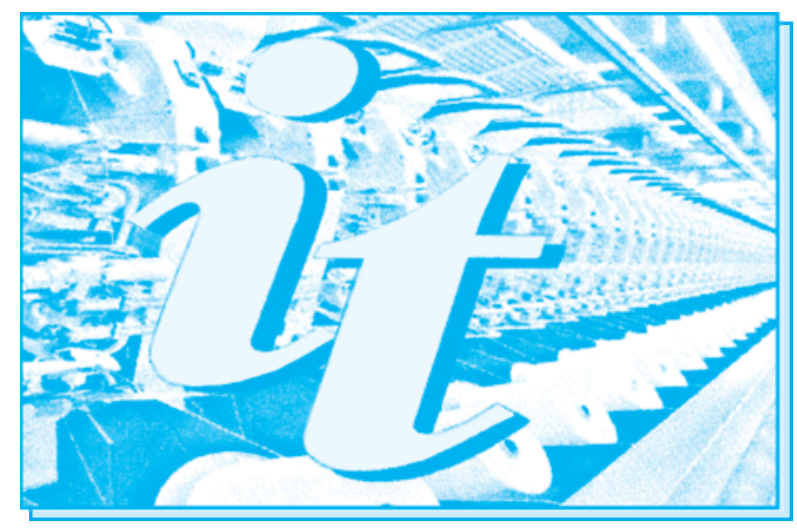

Revistă cotată ISI si inclusă în Master Journal List a Institutului pentru Știința Informării din Philadelphia - S.U.A., începând cu vol. 58, nr. 1/2007/

ISI rated magazine, included in the ISI Master Journal List of the Institute of Science Information, Philadelphia, USA, starting with vol. 58, no. 1/2007

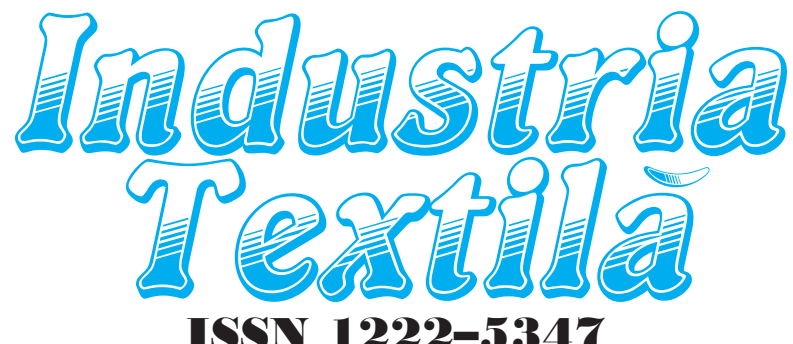

ISSN 1222-5347

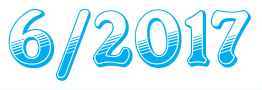

Editată în 6 nr./an, indexată si recenzată în:

Edited in 6 issues per year, indexed and abstracted in:

Science Citation Index Expanded (SciSearch ${ }^{\circledR}$ ), Materials Science Citation Index ${ }^{\circledR}$, Journal Citation Reports/Science Edition, World Textile

Abstracts, Chemical Abstracts, VINITI, Scopus, Toga FIZ technik ProQuest Central

Editată cu sprijinul Ministerului Cercetării și Inovării

\section{COLEGIUL DE REDACTIE:}

Dr. ing. CARMEN GHITULEASA CS I - DIRECTOR GENERAL Institutul Naţional de Cercetare-Dezvoltare pentru Textile şi Pielărie - Bucureşti

Dr. ing. EMILIA VISILEANU CS I- EDITOR ŞEF

Institutul Naţional de Cercetare-Dezvoltare pentru Textile şi Pielărie - Bucureşti

Conf. univ. dr. ing. MARIANA URSACHE DECAN

Facultatea de Textile-Pielărie şi Management Industrial, Universitatea Tehnică „Ghe. Asachi“ - laşi

Prof. dr. GELU ONOSE CSI

Universitatea de Medicină şi Farmacie "Carol Davila" - Bucureşti

Prof. dr. ing. ERHAN ÖNER Marmara University - Turcia

Prof. dr. S. MUGE YUKSELOGLU Marmara University - Turcia

Prof. univ. dr. DOINA I. POPESCU Academia de Studii Economice - Bucureşti

Prof. univ. dr. ing. CARMEN LOGHIN Facultatea de Textile-Pielărie şi Management Industrial, Universitatea Tehnică „Ghe. Asachi“ - laşi

Prof. univ. dr. MARGARETA STELEA FLORESCU Academia de Studii Economice - Bucureşti

Prof. ing. ARISTIDE DODU

Membru de onoare al Academiei de Ştiinţe Tehnice din România

Prof. dr. ing. LUIS ALMEIDA

University of Minho - Portugal

Prof. dr. LUCIAN CONSTANTIN HANGANU Universitatea Tehnică „Ghe. Asachi“ - laşi

\section{Dr. AMINODDIN HAJI}

PhD, MSc, BSc, Textile Chemistry and Fiber Science Assistant Professor

Textile and Art Department Islamic Azad University, Birjand Branch Birjand, Iran

\section{GÜNAYDIN KARAKAN GIZEM, CEVEN ERHAN KENAN}

Studiu privind proprietățile de rezistență la întindere și proprietățile de abraziune ale țesăturilor din fire de poliester de tip convențional și ignifuge

407-414

\section{SI CHEN, XIAO-QING WANG}

Caracterizarea proprietăților de impact și postimpact (CAI) ale compozitelor cu structură $3 \mathrm{D}$

\section{POLONA DOBNIK DUBROVSKI, ABHIJIT MAJUMDAR}

Efectele porozitătii deschise si ale parametrilor de constructie asupra factorului de protectie la ultraviolete al tesăturilor

DENIZ OZDEN, GULDEMET BASAL

Filtru HEPA acoperit cu nanofibră de poliamidă 6/chitosan pentru controlul bioaerosolului

ABDUL WAQAR RAJPUT, USMAN ALI, AMIR ABBAS, RANA AMJAD, SIDRA SALEEMI

Efectul densității lineare a semitortului asupra parametrilor de calitate ai firelor de bumbac $16 \mathrm{Nec}$

IULIANA IASSNICU (STAMATE), GHEORGHITA TOMESCU, OVIDIU VASILE, VIVIANA FILIP, SIMONA MIHAI

Analiza influenței utilizării materialelor textile recuperate asupra proprietăților acustice ale materialelor compozite

NESMA SAOUSSEN ACHOUR, MOHAMED HAMDAOUI,

\section{SASSI BEN NASRALLAH}

Efectul parametrilor de evaporare şi tricotare asupra comportamentului de permeabilitate: abordări experimentale și analitice

MARIJA SAVIC, DUSAN TRAJKOVIC, JOVAN STEPANOVIC,

PETAR STOJANOVIC, MIRJANA KOSTIC, DIVNA MAJSTOROVIC Influenta temperaturii si vitezei de texturare asupra caracteristicilor fizico-mecanice ale firelor de poliamidă texturate prin procedeul de falsă torsiune

AKCAGUN ENGIN, ÖZ CEVIZ NURAY, YILMAZ ABDURRAHIM, MAZARI ADNAN

Investıgarea proprietăţılor de confort termıc ale jachetelor bărbăteştı dın materıale mono- şı multıstrat

LAURENTIU-CHRISTIAN DINCĂ, HORTENSIA-CLARA RĂDULESCU, DIONEZIE BOJIN, EMILIA VISILEANU, ALINA POPESCU, CARMEN-PYERINA GHITULEASA

Analize statistice dimensionale comparative, prin SEM, între nanotratamentele de CuO nemetalizate şi metalizate cu aur, de pe substraturi textile

ADRIAN SALISTEAN, DANIELA FARIMA, MIHAI CIOCOIU, CONSTANTIN NITE

Optimizări ale proiectării parașutei de tip ram-air

HUA YUAN, JUNJIE ZHANG, YUN ZHANG, YAN HONG,

HONGZHONG ZHAO

Efectele externalităților de aglomerare asupra productivității totale: exemple din industria textilă din China

Recunoscută în România, în domeniul Științelor inginerești, de către Consiliul Național al Cercetării Științifice din Învățământul Superior (C.N.C.S.I.S.), în grupa A /

Aknowledged in Romania, in the engineering sciences domain, by the National Council of the Scientific Research from the Higher Education (CNCSIS), in group $A$ 


\section{Contents}

GÜNAYDIN KARAKAN GIZEM, ÇEVEN ERHAN KENAN

SI CHEN, XIAO-QING WANG

POLONA DOBNIK DUBROVSKI, ABHIJIT MAJUMDAR

DENIZ OZDEN, GULDEMET BASAL

ABDUL WAQAR RAJPUT, USMAN ALI, AMIR ABBAS, RANA AMJAD, SIDRA SALEEMI

IULIANA IASNICU (STAMATE), GHEORGHITSA TOMESCU,

OVIDIU VASILE, VIVIANA FILIP, SIMONA MIHAI

NESMA SAOUSSEN ACHOUR, MOHAMED HAMDAOUI, SASSI BEN NASRALLAH

MARIJA SAVIC, DUSAN TRAJKOVIC JOVAN STEPANOVIC

PETAR STOJANOVIC, MIRJANA KOSTIC, DIVNA MAJSTOROVIC

\section{AKCAGUN ENGIN, ÖZCEVIZ NURAY,} YILMAZ ABDURRAHIM, MAZARI ADNAN

LAURENTIU-CHRISTIAN DINCĂ, HORTENSIA-CLARA RĂDULESCU, DIONEZIE BOJIN, EMILIA VISILEANU, ALINA POPESCU,

CARMEN-PYERINA GHIȚULEASA

ADRIAN SALISTEAN, DANIELA FARIMA, MIHAI CIOCOIU, CONSTANTIN NITE

HUA YUAN, JUNJIE ZHANG, YUN ZHANG, YAN HONG, HONGZHONG ZHAO
A research on tensile and abrasion properties of fabrics produced from conventional and fire resistant type polyester yarns

Characterization of the impact and post impact (CAI) properties of 3D-structure composites

The effects of open porosity and constructional parameters on cotton woven fabric's ultraviolet protection factor

Polyamide 6/chitosan nanofiber coated HEPA filter for bioaerosol control

Effect of roving linear density on the quality parameters of $16 \mathrm{Nec} 100 \%$ cotton yarn

Analysis on the influence of the use of recovered textiles on the acoustic properties of composite materials

Effect of the evaporation and knitting parameters on wicking behaviours

Experimental and analytical approaches

Influence of heater temperature and texturing speed on the physical-mechanical propertiesof polyamide textured yarns in false-twist texturing process

Investigating the thermal comfort properties of men's jacket as single and multiple layered material

Comparative dimensional statistical analyses by SEM, between unmetallized and gold-metallized CuO-nanotreatments from textile substrates

Effects of agglomeration externalities on total factor productivity: evidence from China's Textile Industry

\section{Scientific reviewers for the papers published in this number:}

Prof. dr. Elsayed Ahmed Einashar, Kafrelsheikh University, Faculty of Specific Education, Egypt

Asist. dr. Silvestru Bogdănel Muntean, Faculty of Physics, "Al. I. Cuza" University, lasi, Romania

Prof. dr. Adrian Buhu, "Gh. Asachi” Technical University, lasi, Romania

Prof. dr. Goran Demboski, University “Ss. Cyril and Methodius”, Faculty of Technology and Metallurgy, Department of Textile Engineering, Skopje, Macedonia

Prof. dr. Doina Popescu, Academy of Economic Studies, Bucharest, Romania

Prof. dr. Margareta Florescu, Academy of Economic Studies, Bucharest, Romania

\section{EDITORIAL STAFF}

Editor-in-chief: Dr. eng. Emilia Visileanu

Graphic designer: Florin Prisecaru

e-mail: industriatextila@ certex.ro

Journal edited in colaboration with Editura AGIR, 118 Calea Victoriei, sector 1, Bucharest, tel./fax: 021-316.89.92; 021-316.89.93; e-mail: editura@agir.ro,www.edituraagir.ro 


\title{
A research on tensile and abrasion properties of fabrics produced from conventional and fire resistant type polyester yarns
}

\author{
DOI: $10.35530 / I T .068 .06 .1484$
}

\section{REZUMAT - ABSTRACT}

Studiu privind proprietățile de rezistență la întindere și proprietățile de abraziune ale țesăturilor din fire de poliester de tip convențional și ignifuge

Acest sudiu are ca obiectiv investigarea proprietăților de abraziune și de rezistență la tracțiune ale țesăturilor din fire de poliester convenționale și ignifuge. În studiul experimental au fost selectate douăsprezece tipuri diferite de țesături compuse din patru fire diferite de bătătură cu trei niveluri de densitate a firelor de bătătură, pentru a determina influența densității firelor de bătătură și parametrii structurali ai firelor (texturarea și adaosul de material ignifug) asupra tenacității și rezistenței la abraziune. Firele de bătătură utilizate au fost: fire de poliester texturate convenționale (CTP), fire de poliester texturate cu jet de aer (ATP), fire de poliester ignifuge texturate convenționale (CTPFR), fire de poliester ignifuge texturate cu jet de aer (ATPFR). Polisterul neted trilobal lucios a fost utilizat ca fir de urzeală pentru toate tipurile de țesături. După țeserea materialelor pentru draperie de tip satinat, testele de abraziune ale țesăturilor au fost efectuate cu echipamentul de testare Martindale, în timp ce testele de tenacitate au fost efectuate cu dispozitivul de testare Instron. Conform rezultatelor analizelor statistice efectuate utilizând valorile experimentale obținute din teste, s-a ajuns la concluzia că proprietățile de rezistență la abraziune și proprietățile de rezistență la tracțiune în direcția urzelii și bătăturii au fost afectate de parametrii structurali ai firelor (cum ar fi: texturarea și adaosul de material ignifug) și de densitatea firelor de bătătură.

Cuvinte-cheie: fir de poliester, ignifug, rezistența la întindere, rezistența la abraziune

\section{A research on tensile and abrasion properties of fabrics produced from conventional and fire resistant type polyester yarns}

This paper is focused on investigating the abrasion and tensile properties of fabrics from conventional and fire resistant type polyester yarns. In the experimental study, twelve different types of fabrics composed of four different weft yarns with three levels of weft density were selected in order to determine the influence of weft density and yarn structural parameters (texturing and addition of flame retardant material) on tenacity and abrasion resistance. The weft yarns were conventional textured polyester yarn (CTP), air-jet textured polyester yarn (ATP), conventional textured flame retardant polyester yarn (CTPFR), air-jet textured flame retardant polyester yarn (ATPFR). Trilobal bright flat polyester was used as the warp yarn for all the fabrics. After the satin type drapery fabrics were woven, the abrasion tests of the fabrics were performed with Martindale test equipment while the tenacity tests were carried out by using Instron test device. According to the results of the statistical analyses performed using the experimental values obtained from the tests, we determined that, the abrasion resistance and the tensile properties in warp and weft directions were affected by the yarn structural parameters ( such as texturing and the addition of flame retardant material) and weft density.

Keywords: polyester yarn, fire resistance, tensile strength, abrasion resistance

\section{INTRODUCTION}

The textile flammability is generally defined with some of the processes such as burning rates, flame spread rates, characteristics for ignition (e.g., delay time, ignition temperature, critical heat flux for ignition).

Flammability property for textile materials may be influenced by many factors including polymer itself, weaving or knitting type, yarn construction, additives in the fiber, chemical treatment type as well as the test conditions [1]. Flame retardant textiles may be applied in different fields such as military, automotive, aerospace applications and safety protective garments. There are four methods for reducing the flammability of textiles. First is using inherently flame retardant textiles including the high performance fibers (e.g., polyoxazoles, polyether etherketone, polymides, carbon, asbestos, glass, polibenzimidazol, kyrol, polifenilensulfur and aramides). The second method is changing the structures of fibers by copolymerization (chlorine content) and chemical modification where the flame retardant monomer is observed in chain structures of fibers (FR polyester, FR polyamide, FR wool) [2-4]. Since the demand for flame retardant polyester (FR) has been recently increasing for the fire protective textiles, some solutions were developed for improving the flame retardant property of polyester. The most widespread and efficient method of FR protection for synthetic fibers such as polyester is adding flame retardants during polymer processing. This method doesn't require new equipment which makes it economically efficient. Trevira CS is an example of FR Polyester production by incorporating a comonomeric phosphinic acid unit into the PET polymeric chain. Halogen containing organic compounds and organophosphorous compounds has also been used as flame retardant 
additives for polyester (PET) fibers. However these groups have been restricted in Europe because of their toxicity and corrosion effect leading to environmental problems. Therefore there is an increasing trend for the development of new environmentally friendly phosphorus containing flame retardants for PET. Additionally some flame additives may be incorporated during polyester extrusion such as (bisphenol-S-oligomer derivatives from Toyobo, cylic phosphonates (Antiblaze CU and 1010 from Rhodia or phosphinate salts from Clariant. The best advantage of these methods is; flame retardant property is not lost through use, washing or ageing since flameresistant properties are permanently built into molecular chain of the fibers. One of other methods usually preferred is the surface treatment of polyester fabric with fire retardant chemicals. This technique is especially appropriate for upholstery fabrics [5-7].

As the literature was reviewed, it can be seen that there are several studies related to FR (flame retardant) polyester textile materials. Yang and Kim investigated the fiber properties, dyeing properties, and flame retardancy according to the phosphorous FR type. Main chain type FR and the pendant (side chain) type FR were compared for the study. They concluded that the physical properties of both fibers were similar and suitable for textile application. But dye adsorption rate was much faster in the case of main chain type [8]. Yu et al. (2015) made an investigation about flame retardant and conductive properties of polyester fabrics coated with polyaniline. Polyester fabrics were coated by polyaniline synthesized via in-situ chemical polymerization and doped with $\mathrm{HCl}$ and $\mathrm{H} 3 \mathrm{PO} 4$. Performance of flame retardancy and conductivity of polyester fabrics were studied via limiting oxygen index (LOI) and cyclic voltammetry measurements. Experimental results indicated that modified polyester fabrics had both excellent flame retardancy and high conductivity [9]. In Ertekin and Kırtay's study para-aramid, metaaramid and flame retardant polyester (FR PES) staple fibres were spun on the ring frame to produce woven fabrics with three different yarn counts ( $\mathrm{Ne} \mathrm{10,}$ $\mathrm{Ne} 20, \mathrm{Ne} 30$ ) of para-aramid, meta-aramid and FR PES yarns as weft yarns. And 2-ply spun para-aramid yarns $(30 / 2 \mathrm{Ne})$ were used as warp yarns. The effect of yarn count and fiber type on mechanical and flammability properties of the woven fabrics were investigated and evaluated statistically. Additionally they compared the carbonized areas on flame spread test [10]. Carosio et al. applied a novel method to improve flame retardant properties of textile fabric using multilayered thin films. PET fabrics were coated with silica nanoparticles using layer-by-layer assembly. Five bilayers of positively and negatively charged colloidal silica ( $<10 \mathrm{~nm}$ average thickness) increased time to ignition and decreased heat release rate peak of PET fabric by $45 \%$ and $20 \%$, respectively [11]. Chen and Wang made an investigation about the developments in flame retardants for different polymeric materials in China, primarily based on the publications that have appeared in the last 15 years. It focuses on the following aspects: halogen-containing flame retardants, inorganic flame retardants (e.g. metal oxides and hydroxides, siliconcontaining materials, ammonium polyphosphate, red phosphorus, and expandable graphite), and organic flame retardants (e.g. aliphatic and aromatic phosphonates, nitrogen-containing organics, and multielement organics) [12]. Kotresh et al. made an investigation about the burning behavior of commercial flame retardant (FR) polyester curtain fabric samples with varying weights in the range of $300-550 \mathrm{~g} / \mathrm{m}^{2}$ by using cone calorimetry. The weight of the fabric per unit area is found to influence the peak heat release rate, rate of heat release (RHR), smoke release and other parameters [13]. Lin et al. investigated the properties of fire-retardant and thermal insulation nonwoven fabrics with FR-polyester hollow fibers. In the study; loose nonwoven fabric (LNF), thermal pressed nonwoven fabric (PNF), needle-punched and thermal pressed nonwoven fabric (NPNF), needle-punched and through-air thermal bonded nonwoven fabrics (NTNF) produced with flame-retardant polyester (PET) hollow fibers (FR-PET fibers) and low- melting-temperature PET fibers (low-Tm fibers) were compared in terms of thermal conductivity [14]. However there is limited research related to comparison of tensile and abrasion properties among the fabrics produced from conventional textured polyester yarns and fire resistant type polyester yarns. As we know texturing is a vital process for the synthetic yarns in order to combine the superior properties of synthetics, like high strength, uniformity and stretch with the features that are unique to natural fibers. The general method for texturing process among the thermoplastic filaments such as polyester is false twist texturing [15]. This study aims to contribute to literature by investigating of the interrelationships and specific influences of woven fabric production parameters like weft yarn type (intersection of texturing type and polyester type ) and weft density on abrasion and tenacity properties of polyester fabrics. Abrasion resistance and tensile properties are important features revealing information about fabric quality and product performance. Additionally we especially emphasize that; modified yarn characteristics lead to new investigations related to flame retardant properties since conventional textured polyester yarn and air-jet textured polyester yarns have also been used as weft yarns separately. The expected target from this study is to observe flame retardant material additive and texturing type influence to the woven fabrics in terms of mechanical properties such as tenacity and abrasion results.

\section{MATERIALS AND METHODS}

\section{Material}

12 different types of fabrics composed of 4 different weft yarns with 3 levels of weft density were selected in order to determine the influence of weft density and yarn structural parameters (such as texturing 
type, the addition of flame retardant material) on tenacity and abrasion resistance.

Masterbatch preparation: Flame retardant material additive used in the study was a commercially available product called Exolit@ OP 950, diethyl aluminium phosphinate (EOP), supplied by Clariant. Exolit OP 950 is a white granular powder based on an organic phosphinate. The pellets of PET/EOP with $80 / 20$ (w/w) composition was used in combination with pure PET pellets to obtain a composite formulation of minimum $4 \mathrm{wt} \%$ flame retardant additive and 96 wt \% PET. The pure PET and PET/additive composite filaments were produced with melt spinning process.

The 50 denier/24 fil, 700 tpm ( $Z$ direction) Fdy Trilobal Bright Flat polyester was used as warp yarn for all fabrics. The conventional disk, air jet textured pure polyester and FR polyester yarns were produced and selected as weft yarns. Weft yarn count was selected as 300 denier/96 fil. The 10/1 weft satin $\mathrm{Z}(3)$ drapery fabrics having warp density of 80 warp/ $\mathrm{cm}$ and weft densities of 36-38-40 weft/cm were weaved on Dornier Staubli Jacquard Machine.

These fabrics will be coded as $\mathbf{A B}$, where:

$A$ is intersection of texturing type and polyester type and $B$ is weft density.

for A: CTP stands for conventional textured polyester weft yarn

ATP stands for air textured polyester weft yarn CTPFR stands for conventional textured FR polyester weft yarn

ATPFR stands for air textured FR polyester weft yarn

for B: 36 stands for 36 weft $/ \mathrm{cm}$

38 stands for 38 weft $/ \mathrm{cm}$

40 stands for 40 weft $/ \mathrm{cm}$

For example CTPFR40 coded fabric indicates the fabric with $40 \mathrm{weft} / \mathrm{cm}$ weft density where conventional textured FR polyester yarn was used as the weft yarn.

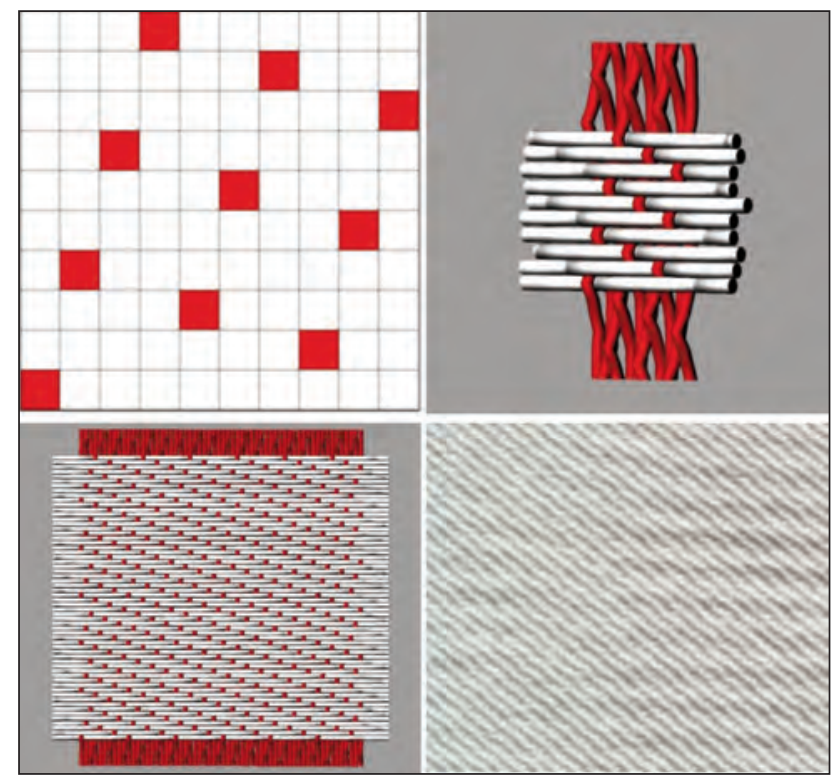

Fig. 1. Photographs of satin weave and KTPFR40 coded fabric

\section{Methods}

Bresser Touch digital microscope was used for microscopic images of polyester weft yarns. Magnification of 40x optical was applied with LED illumination of $490 \mathrm{~nm}$ during the collection of yarn images. The fibers' surface morphology was also observed via SEM (Scanning Electron Microscope) technique. For this process, the fiber samples were coated with gold by using the plasma spray equipment. Observations were obtained at Physics department of Uludag University by using the CARL ZEISS EVO 40 (ZEISS Co., Oberkochen, Germany) Electron microscope with the resolution of $3.0 \mathrm{~nm} 30 \mathrm{kV}$ (SE) at the voltage of $0,230 \mathrm{kv}$. The magnifying degree was selected as; 2500x and 5000x .

Prior to abrasion and tenacity tests, all yarn and fabric samples were conditioned for 24 hours in standard atmospheric conditions (at the temperature of $20 \pm 2{ }^{\circ} \mathrm{C}$ and relative humidity of $65 \pm 2 \%$ ). The polyester weft yarns of the fabrics were subjected to tensile test with Instron 401 test equipment according to ISO 2062 standard [16]. The test parameters were adjusted as; $500 \mathrm{~mm}$ gauge length, $10 \mathrm{cN}$ pretension, $5 \mathrm{~kg}$ load cell and $500 \mathrm{~mm} / \mathrm{min}$ test speed for the yarn samples. Ten tests were performed for each yarn type. And the mean values were recorded.

In order to examine the potential changes in the mechanical properties due to the incorporation of additive, the fabric samples were subjected to abrasion test, to fabric tenacity tests in warp and weft directions [17, 18]. The abrasion resistances of the fabrics were tested with Martindale Abrasion Tester according to ISO 12947-3 standard determined by the mass loss as the difference between the masses before and after abrasion cycles of 30,000 with the nominal pressure of $12 \mathrm{kPa}$. The tensile properties of 12 different fabric samples were measured with the 4301 Instron testing device according to ISO 13934-1 standard for the weft and warp fabric wise. Test parameters for the fabric samples were $50 \mathrm{~mm}$ fabric width, $200 \mathrm{~mm}$ gauge length between the clamps and $100 \mathrm{~mm} / \mathrm{min}$ speed of extension. Ten tests were performed for each fabric type. Breaking strength (kN) and breaking elongation (\%) of the fabrics in weft and warp wise were measured.

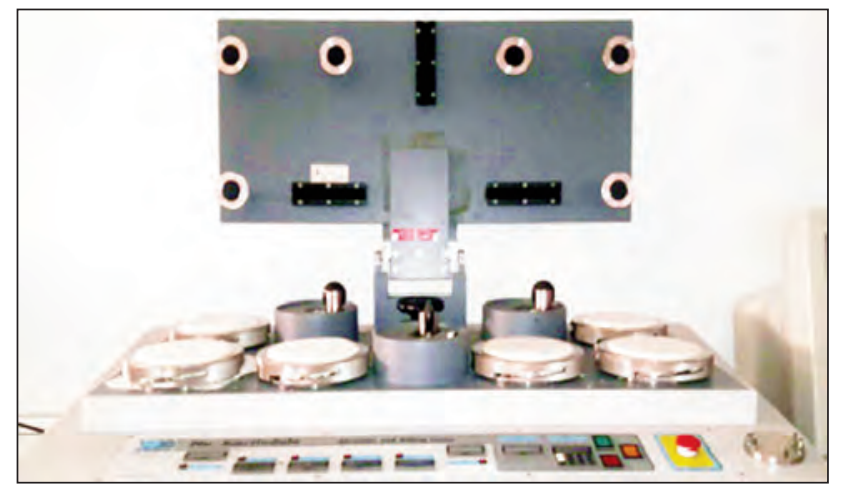

Fig. 2. Martindale Test Device (Uludag University, Textile Engineering Laboratory) 


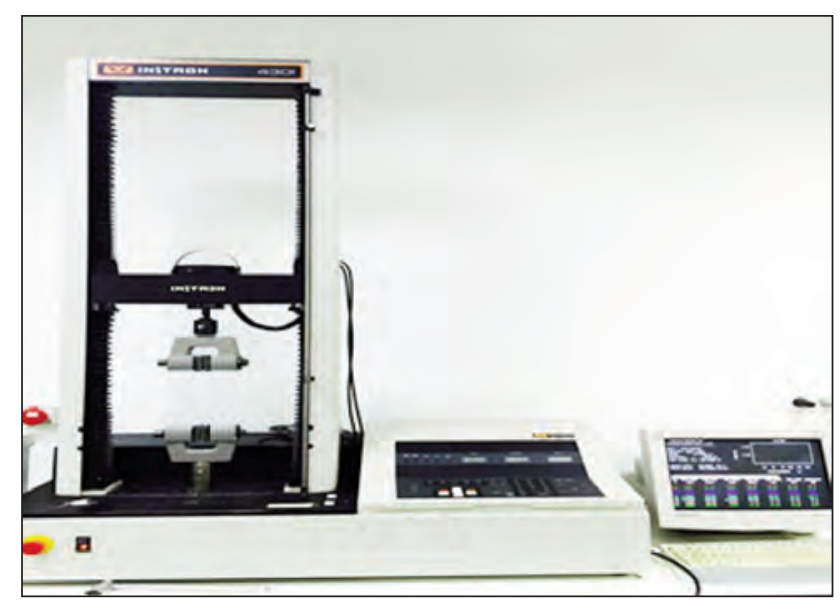

Fig. 3. Photo of the Instron Device (Uludağ University, Textile Engineering Department, Physical Testing and Analysis Laboratory)
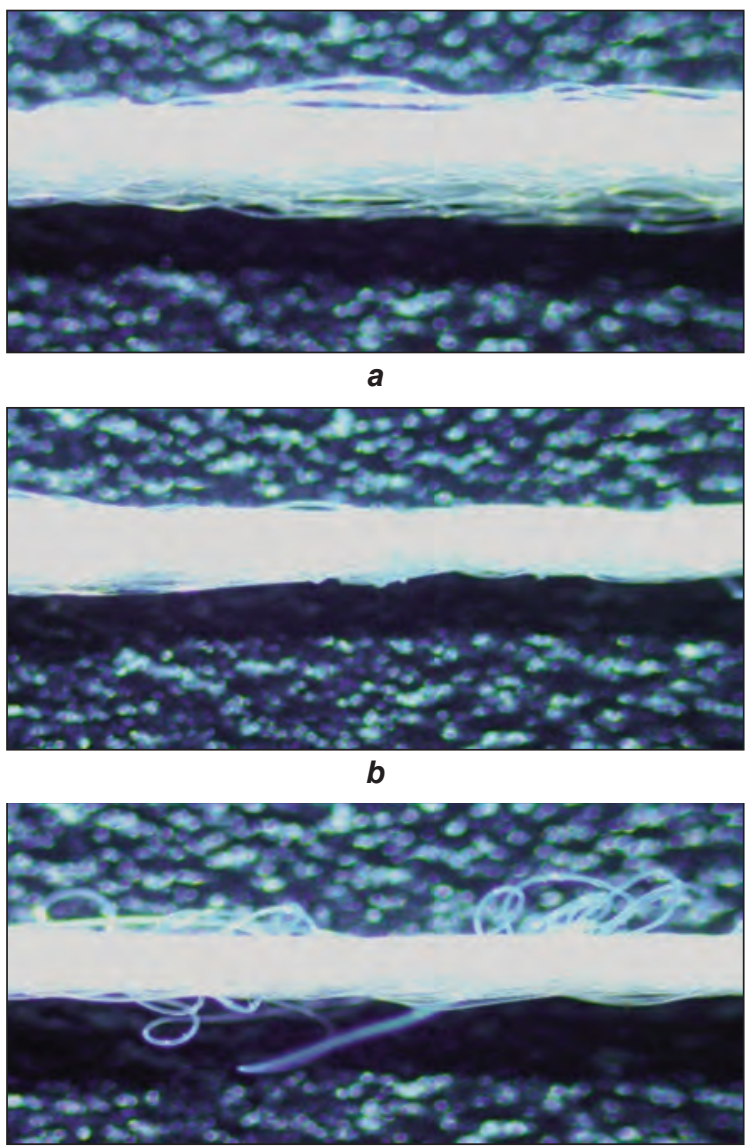

c

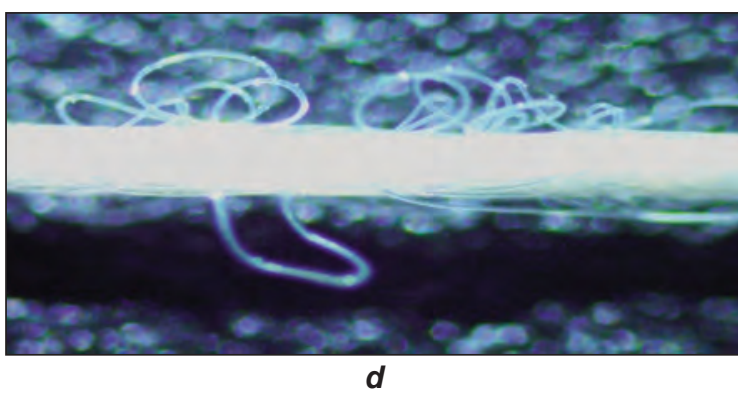

Fig. 4. Microscopic images of weft yarns: a - Conventional Textured Polyester (CTP); $b$ - Conventional Textured Polyester-FR (CTPFR); $c$ - Air Textured Polyester (ATP); $d$ - Air Textured Polyester-FR (ATPFR)

industuia textilă

\section{Statistical evaluation}

All statistical procedures were conducted using the SPSS 23.0 Statistical software package. In the study completely randomized two-factor analysis of variance (ANOVA) was used for the determination of the statistical significance of the yarn structural parameters as yarn type and fabric density. The means were compared by Student-Newman-Keuls (SNK) tests. The value of significance level $(\alpha)$ selected for all statistical tests in the study is 0.05 . The treatment levels were marked in accordance with the mean values, and any levels marked by different letter (a, b, c) showed that they were significantly different.

\section{RESULTS AND DISCUSSION}

Optical microscopy and SEM results of the weft yarns

Optical microscope views of 12 different weft yarns were revealed in figure 4 and cross sectional-SEM images of PET yarns are revealed in figure 4 . It is

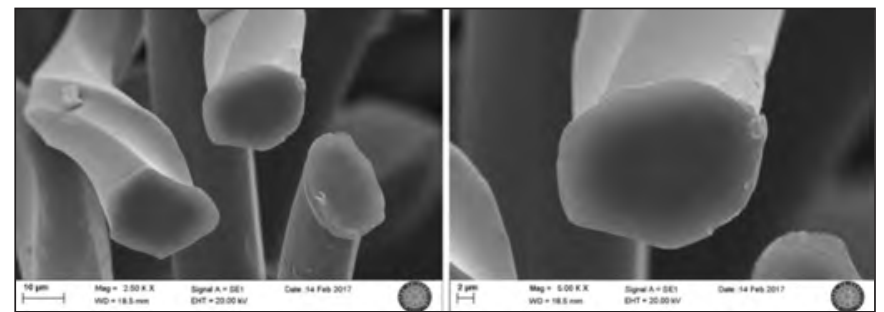

a: Conventional Textured Polyester (CTP),

(2,5 $\mathrm{K}$ and $5 \mathrm{~K}$ magnification)

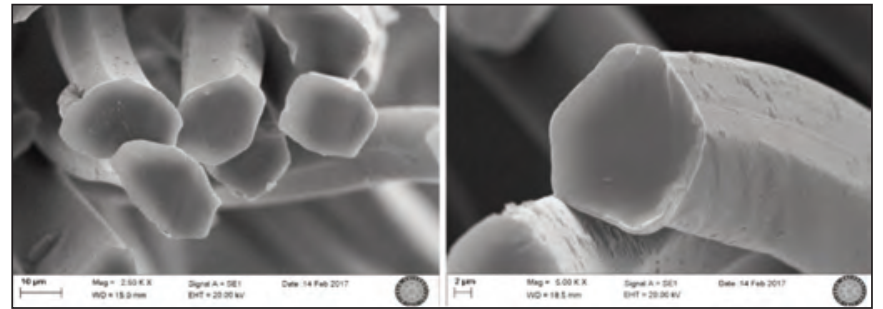

b: Conventional Textured Polyester-FR (CTPFR) (2,5 $\mathrm{K}$ and $5 \mathrm{~K}$ magnification)

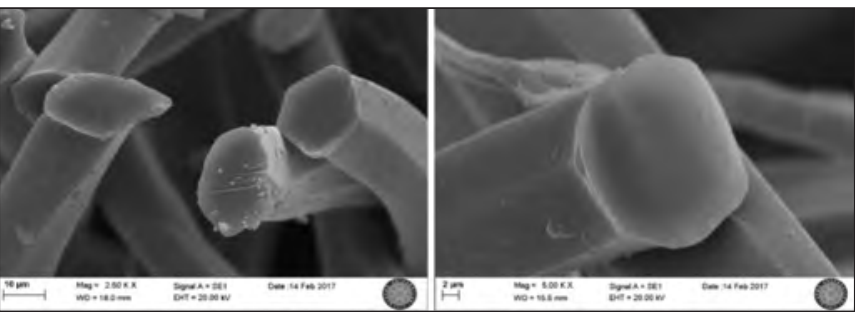

c: Air Textured Polyester (ATP) (2,5 K and $5 \mathrm{~K}$ magnification)

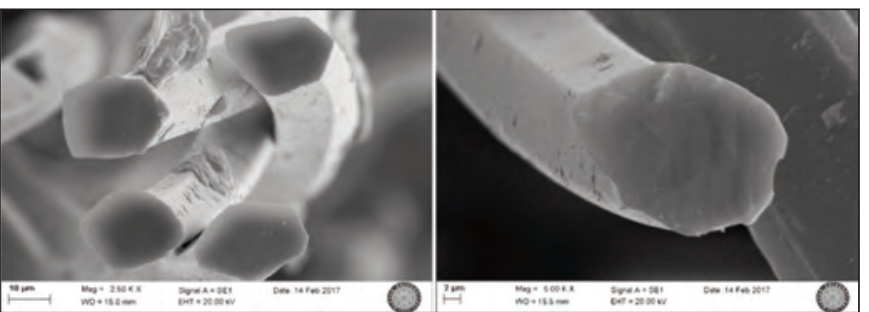

d: Air Textured Polyester-FR ( ATPFR ) (2,5 K and $5 \mathrm{~K}$ magnification)

Fig. 5. SEM images of weft yarns 2017, vol. G8, nr. 6 


\begin{tabular}{|l|c|c|c|c|c|}
\hline \multicolumn{5}{|c|}{ MECHANICAL PROPERTIES OF POLYESTER WEFT YARNS } \\
\hline \multirow{2}{*}{ PRODUCTS } & \multicolumn{5}{c|}{ MECHANICAL PROPERTIES } \\
\cline { 2 - 6 } & \multirow{2}{*}{ DENIER } & \multicolumn{2}{c|}{ ELONGATION } & \multicolumn{2}{c|}{ TENACITY } \\
\cline { 3 - 6 } & & $\%$ & CV\% & cN/dtex & cV\% \\
\hline Conventional Textured Polyester (CTP) & 300 & 23.79 & 5.88 & 3.71 & 2.26 \\
\hline Conventional Textured Polyester-FR (CTPFR) & 300 & 26.06 & 5.94 & 2.97 & 2.01 \\
\hline Air Textured Polyester (ATP) & 300 & 24.11 & 11.34 & 2.67 & 5.09 \\
\hline Air Textured Polyester-FR (ATPFR) & 300 & 29.26 & 6.05 & 2.3 & 2.63 \\
\hline
\end{tabular}

possible to see the effects of FR process to the individual fibers.

\section{Tensile test results of yarns}

Table 1 reveals the mechanical properties of polyester weft yarns used in the study.

\section{Tenacity results of the fabrics}

The average weft wise and warp wise breaking tenacity results of the fabrics were demonstrated in figure 6 and figure 7 . The $p$-values associated with Ftests for a two-way completely randomized ANOVA and SNK test values for the tenacity test results in weft and warp directions were presented in table 2, table 3 , table 4 and table 5 respectively.

\section{Tenacity resul ts in weft direction}

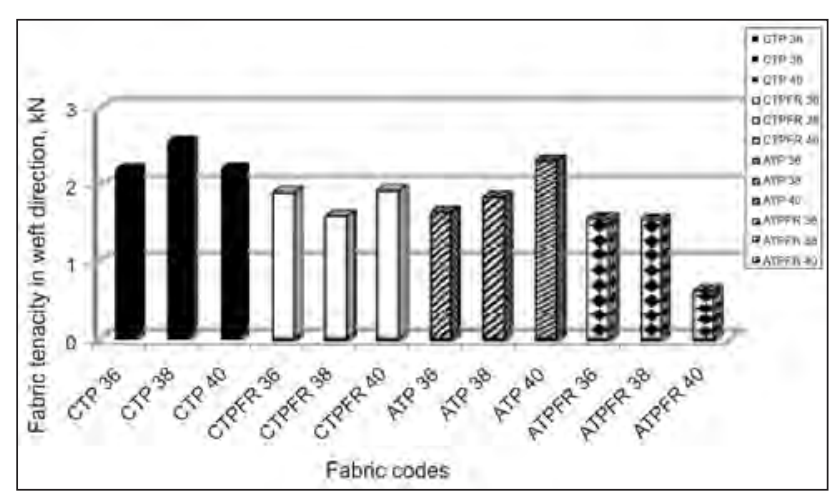

Fig. 6. Tenacity results of the fabrics in weft direction

Tenacity results of the fabrics in weft direction were shown in figure 6 . According to figure 6 , maximum weft tenacity value was obtained in CTP 38 coded yarn types while the minimum was observed in ATPFR 40 yarn type. When we examined the results of the ANOVA test given in table 2; there were statistically significant ( $5 \%$ significance level) differences between the fabric tenacity values in weft direction of the fabrics produced by 4 different yarn types. Another aspect about the fabric tenacity in weft direction results was that there were significant differences between the fabric tenacity in weft direction values of the fabrics with 3 different weft densities. The effect of the interaction between yarn type and weft density on fabric tenacity in weft direction was significant.
Table 2

\begin{tabular}{|c|c|c|c|c|}
\hline \multicolumn{5}{|c|}{$\begin{array}{l}\text { UNIVARIATE ANOVA RESULTS FOR TENACITY } \\
\text { IN WEFT DIRECTION }\end{array}$} \\
\hline \multicolumn{2}{|c|}{ Source } & df & $\mathbf{F}$ & Sig.(p) \\
\hline \multirow{2}{*}{ Main effect } & Yarn Type (T) & 3 & 762.236 & 0.000 \\
\hline & Weft Density (D) & 2 & 17.525 & 0.000 \\
\hline Interaction & $T \times D$ & 6 & 198.173 & 0.000 \\
\hline
\end{tabular}

Table 3

\begin{tabular}{|l|c|c|}
\hline \multicolumn{3}{|c|}{ SNK TEST RESULTS FOR TENACITY IN WEFT } \\
DIRECTION \\
\hline \multicolumn{2}{|c|}{ Parameter } & $\begin{array}{c}\text { Tenacity in weft } \\
\text { direction (kN) }\end{array}$ \\
\hline \multirow{4}{*}{ Yarn type (T) } & ATPFR & $1.24 \mathrm{a}$ \\
\cline { 2 - 3 } & CTPFR & $1.79 \mathrm{~b}$ \\
\cline { 2 - 3 } & ATP & $1.93 \mathrm{c}$ \\
\cline { 2 - 3 } & CTP & $2.33 \mathrm{~d}$ \\
\hline \multirow{3}{*}{ Weft Density (D) } & 40 & $1.77 \mathrm{a}$ \\
\cline { 2 - 3 } & 36 & $1.82 \mathrm{~b}$ \\
\cline { 2 - 3 } & 38 & $1.88 \mathrm{c}$ \\
\hline
\end{tabular}

NOTE: The different letters next to the counts indicate that they are significantly different from each other at a significance level of $5 \%$

SNK test results in table 3 revealed that the fabrics produced with different yarn types possessed statistically different tenacity in weft directions. Tenacity value in weft direction for yarn type: ATPFR was 1.24 while that for the yarn type: CTPFR was 1.79, ATP was 1.93, CTP was 2.33. Fabrics with FR type polyester yarns had lower tenacity values than those with standard type polyester yarns. Also, conventional texturing led to higher tenacity in weft direction than the air texturing. Depending on weft density; the highest fabric tenacity in weft direction was obtained for weft density of 38 , and the lowest fabric tenacity in weft direction was obtained for weft density of 40 . There was not a trend for the change in weft wise tenacity values with the increment of weft density. 


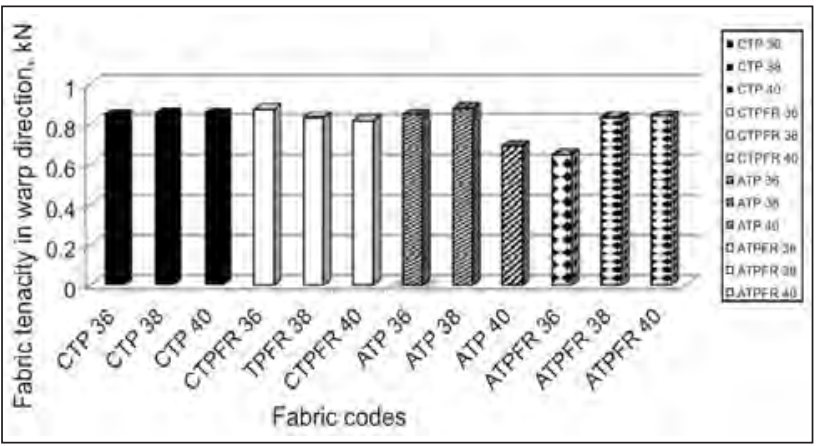

Fig. 7. Tenacity results of the fabrics in warp direction

The diagram of warp wise tenacity of the fabrics was demonstrated in figure 7. According to figure 7, maximum warp tenacity values were obtained from ATP 38 yarn types while the minimum was obtained from ATPFR 36 yarn type.

The results of the of ANOVA test given in table 4 indicated that; there were statistically significant $(5 \%$ significance level) differences between the fabric tenacity values in warp direction of the fabrics produced by 4 different yarn types. Another aspect about the fabric tenacity in warp direction results was that there were significant differences between the fabric tenacity in warp direction values of the fabrics with 3 different weft density. The effect of the interaction between yarn type and weft density on fabric tenacity in warp direction was significant.

SNK test results in table 5 revealed that the fabrics produced with different yarn types possessed statistically different tenacity in warp directions. Tenacity value in warp direction for yarn type: ATPFR was 0.77 while that for the yarn type: CTPFR was 0.84 , ATP was 0.81 and CTP was 0.86 . The tenacity values in warp direction for yarn type of CTPFR and CTP were statistically in the same level. Fabrics with FR type polyester yarns had lower tenacity values than those with standard type polyester yarns. Conventional texturing led to higher tenacity in warp direction than the air texturing. Depending on the weft density the highest fabric tenacity in warp direction was obtained from fabrics with weft density of 38 $(0.85 \mathrm{kN})$, while the fabric tenacities in warp direction with weft densities of 40 and 36 were statistically same with $0.80 \mathrm{kN}$ value. This situation is attributed to the fact that usage of different weft yarn types weakened the effect of weft density on warp wise fabric tenacity.

\section{Abrasion resistance}

The diagram of mass losses of the 12 different sample fabrics was demonstrated in figure 8. According to figure 8 the maximum mass loss value was obtained from ATPFR 36 yarn type while the minimum was obtained from ATP 38 yarn type. In addition to this, mass loss values of the fabrics with yarn type of conventional textured polyester FR (CTPFR) were higher than those of the fabrics with yarn type of
UNIVARIATE ANOVA RESULTS FOR TENACITY IN WARP DIRECTION

\begin{tabular}{|c|c|c|c|c|}
\hline \multicolumn{2}{|c|}{ Source } & df & F & Sig.(p) \\
\hline \multirow{2}{*}{ Main effect } & Yarn Type (T) & 3 & 15.723 & 0.000 \\
\cline { 2 - 5 } & Weft Density (D) & 2 & 10.723 & 0.000 \\
\hline Interaction & T x D & 6 & 24.782 & 0.000 \\
\hline
\end{tabular}

Table 5

\begin{tabular}{|c|c|c|}
\hline \multicolumn{3}{|c|}{$\begin{array}{c}\text { SNK TEST RESULTS FOR TENACITY IN WARP } \\
\text { DIRECTION }\end{array}$} \\
\hline \multicolumn{2}{|c|}{ Parameter } & $\begin{array}{c}\text { Tenacity in warp } \\
\text { direction (kN) }\end{array}$ \\
\hline \multirow{4}{*}{ Yarn type (T) } & ATPFR & $0.77 \mathrm{a}$ \\
\cline { 2 - 3 } & ATP & $0.81 \mathrm{~b}$ \\
\cline { 2 - 3 } & CTPFR & $0.84 \mathrm{c}$ \\
\cline { 2 - 3 } & CTP & $0.86 \mathrm{c}$ \\
\hline \multirow{3}{*}{ Weft Density (D) } & 40 & $0.80 \mathrm{a}$ \\
\cline { 2 - 3 } & 36 & $0.80 \mathrm{a}$ \\
\cline { 2 - 3 } & 38 & $0.85 \mathrm{~b}$ \\
\hline
\end{tabular}

NOTE: The different letters next to the counts indicate that they are significantly different from each other at a significance level of $5 \%$

conventional textured (CTP) at the weft densities of 36 and 38 and mass loss values of the fabrics with yarn type of air textured polyester FR (ATPFR) were higher than those of the fabrics with yarn type of air textured polyester type (ATP) at all weft densities. This situation may be explained as; the addition of flame retardant additive in yarn spinning process had a negative influence on yarn's abrasion behaviour and the fabric groups produced with conventional textured polyester FR (CTPFR) and air textured polyester FR (ATPFR) yarn type had greater mass loss ratios (\%).

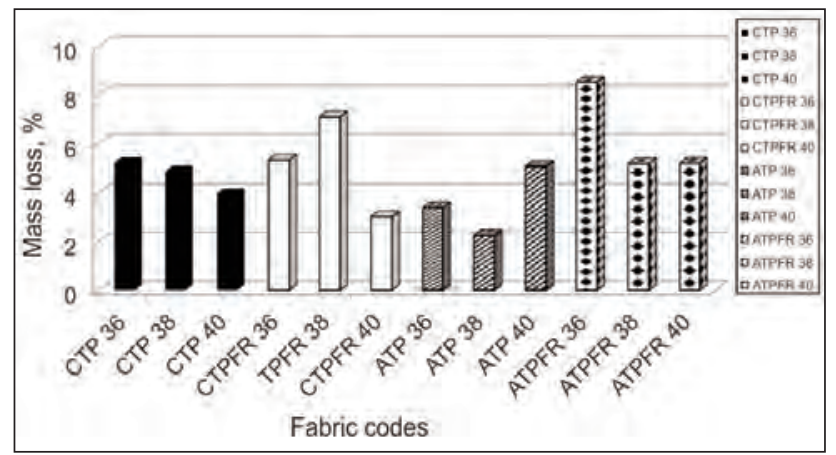

Fig. 8. Mass loss ratios (\%) of the fabrics

The results of the of ANOVA test given in table 6 indicated that; there were statistically significant $(5 \%$ significance level) differences between the mass loss values of the fabrics produced by 4 different yarn 


\begin{tabular}{|c|c|c|c|c|}
\hline \multicolumn{5}{|c|}{ UNIVARIATE ANOVA RESULTS FOR MASS LOSS } \\
\hline \multicolumn{2}{|c|}{ Source } & df & $\mathbf{F}$ & Sig.(p) \\
\hline \multirow{2}{*}{ Main effect } & Yarn Type $(\mathrm{T})$ & 3 & 574.688 & 0.000 \\
\hline & Fabric Density (D) & 2 & 5.176 & 0.000 \\
\hline Interaction & $T \times D$ & 6 & 430.487 & 0.027 \\
\hline
\end{tabular}

Table 7

\begin{tabular}{|c|c|c|}
\hline \multicolumn{3}{|c|}{ SNK TEST RESULTS FOR MASS LOSS } \\
\hline \multicolumn{2}{|c|}{ Parameter } & Mass loss ratio, \% \\
\hline \multirow{4}{*}{ Yarn type (T) } & ATP & $3.58 \mathrm{a}$ \\
\cline { 2 - 3 } & CTP & $4.68 \mathrm{~b}$ \\
\cline { 2 - 3 } & CTPFR & $5.15 \mathrm{c}$ \\
\cline { 2 - 3 } & ATPFR & $6.30 \mathrm{~d}$ \\
\hline \multirow{3}{*}{ Weft Density (D) } & 40 & $4.32 \mathrm{a}$ \\
\cline { 2 - 3 } & 38 & $4.85 \mathrm{~b}$ \\
\cline { 2 - 3 } & 36 & $5.62 \mathrm{c}$ \\
\hline
\end{tabular}

NOTE: The different letters next to the counts indicate that they are significantly different from each other at a significance level of $5 \%$

types. Another aspect about the abrasion test results was that there were significant differences between the mass loss values of the fabrics with 3 different fabric densities. The effect of the interaction between yarn type and fabric density on mass loss was also significant.

SNK test results in table 7 revealed that the fabrics produced with different yarn types possessed statistically different mass loss values. Mass loss value for yarn type: ATP was $3.58 \%$ while that for the yarn type: CTP was $4.68 \%$, CTPFR was $5.15 \%$, ATPFR was $6.30 \%$. Mass loss values of the fabrics increased with the usage of FR type polyester weft yarns. There was not a trend for the ranking of fabric mass loss values with respect to the texturing method. The SNK test results also revealed that the fabrics with different weft density possessed statistically different mass loss values. Mass loss values for the weft density of 36 was $5.62 \%$ while that for the weft density of 38 was $4.85 \%$ and for the weft density of 40 was $4.32 \%$. It was observed as the weft density increased, the average mass loss values decreased. This can be attributed to the high number of contact points leading to lower rates of fabric attrition with the high weft density ratios.

\section{CONCLUSIONS}

The objective of this study was to investigate the influences of polyester weft yarn types (intersection of texturing type and polyester type) and weft densities on abrasion and tensile properties of woven fabrics from these yarns. According to the statistical tests performed on the measurements, the effect of weft yarn type on abrasion resistance was significant. Abrasion values of the fabrics decreased with the usage of FR type polyester weft yarns. Overall it was clearly demonstrated by the statistical tests that both the weft wise and warp wise tenacity values of fabrics depend on the weft yarn type. FR type polyester weft yarns led the decrease in weft wise and warp wise fabric tenacity values. Also, the texturing type has an effect on the tenacity values. Conventional textured polyester and air textured polyester yarns led to statistical differences. Fabrics with air textured polyester yarns had lower tenacity values than the fabrics with conventional textured polyester yarns in the warp and weft wise. There was not a trend for the ranking of fabric abrasion values with respect to the textured type. Another finding was that, as the weft density increased, the average mass loss values after abrasion decreased. There was not a trend for the change in tenacity values both in weft and warp directions with the increment of weft density. Finally, it could be concluded that it will be useful to make further studies on determining the effect of FR additives on other physical properties of fabrics from polyester yarns. The physical properties which should be highlighted are yarn to yarn and yarn to metal friction behavior.

\section{BIBLIOGRAPHY}

[1] Landrock, A.H., 1978, Handbook of plastic flammability and combustion toxicology, In: Noyes Publications Park Ridge New Jersey, United States, 1978.

[2] Pan, N., Sun, G., 2011, Functional Textiles for improved performance protection and health, In: Woodhead publishing Series in textiles in association with The Textile Institute, 2011, Cambridge England.

[3] Levchik, S.V., Weil, E.D. A review on thermal decomposition and combustion of thermoplastic polyesters, In: Polymers for Advanced Technologies, 2004, 15: 691-700 DOI: 10.1002/pat.526.

[4] Horrocks, A.R. Developments in flame retardants for heat and fire resistant textiles-the role of char formation and intumescence, In: Polymer Degradation and Stability, 1996, Vol. 54, Issues 2-3, 143-154 DOI: 10.1016/S01413910(96)00038-9.

[5 Horrocks, R., Anand, S.C. Handbook of technical textiles: Technical fibers for heat and flame protection, Vol. 2 (Technical Textile Applications), In: Woodhead publishing Series in textiles in association with The Textile Institute, Cambridge England, 2016.

[6] Horrocks, A.R. Flame retardant challenges for textiles and fibres: new chemistry versus innovatory solutions, In: Polymer Degradation and Stability, 2011, 96(3), pp. 377-392. 
[7] Chivas, C., Guillaume, E., Sainrat, A., Barbosa, V. Assessment of risks and benefits in the use of flame retardants in upholstered furniture in continental Europe, In: Fire Safety Journal, 2009, 44(5), 801-807.

[8] Yang, S.C., Kim, J.P. Flame retardant polyesters. III. Fibers, In: Journal of Applied Polymer Science, 2008, 108(4), pp. 2297-2300.

[9] Yu, J., Zhou, T., Pang, Z., Wei, Q. Flame retardancy and conductive properties of polyester fabrics coated with polyaniline, In: Textile Research Journal , 2015, vol. 86, no. 11,1171-1179, DOI: 10.1177/0040517515606360.

[10] Ertekin, M., Kırtay, E. Burning behaviour and mechanical properties of fabrics woven with ring spun aramid and flame retardant polyester yarns, In: Journal of Textile \& Apparel/Tekstil ve Konfeksiyon, Jul/Sep2014, 2014, Vol. 24 Issue 3, pp. 259-265.

[11] Carosio, F., Laufer, G., Alongi, J., Camino, G., Grunlan, J.C. Layer-by-layer assembly of silica-based flame retardant thin film on PET fabric, In: Polymer Degradation and Stability, 2011, 96 (5), pp. 745-750.

[12] Chen, L., Wang, Y. A review on flame retardant technology in China. Part I: development of flame retardants, In: Polymer Advanced Technologies, 2009, Vol. 21, Issue 1, 1-26. 10.1002/pat.1550.

[13] Kotresh, T.M., Indushekar, R., Subbulakshmi, M.S., Vijayalakshmi, S.N., Prasad, A.K., Agrawal, A.K. Evaluation of Commercial Flame Retardant Polyester Curtain Fabrics in the Cone Calorimeter, In: Journal of Industrial Textiles, 2006, 36(1), 47-58, doi: 10.1177/1528083706064379.

[14] Lin, C.M., Tsai, I.J., Lin, J.H. Manufacturing and properties of fire-retardant and thermal insulation nonwoven fabrics with FR-polyester hollow fibers, In: Textile Research journal, 2009, 79(11), pp. 993-100.

[15] Çelik, P., Süpüren, G., Özdil, N. Experimental investigation on the static and dynamic strength of false twist textured polyester yarns, In: Industria Textila, 2011, vol. 62, nr. 1, pp. 38-43.

[16] ISO 2062, Breaking Force and Elongation of Yarns, Geneva, Switzerland, 2009.

[17] ISO 12947-3, Determination of the abrasion resistance of fabrics by the Martindale method - Part 3: Determination of mass loss, Geneva, Switzerland, 1998.

[18] ISO 13934-1, Determination of maximum force and elongation at maximum force using the strip method, Geneva, Switzerland, 2013.

Authors:
GÜNAYDIN KARAKAN GIZEM ${ }^{1}$
ÇEVEN ERHAN KENAN ${ }^{2}$
19amukkale University, Buldan Vocational School
20400, Buldan, Denizli, Turkey
e-mail: ggunaydin@pau.edu.tr
2 Uludağ University, Faculty of Eng., Textile Eng. Department
16059, Nilüfer, Bursa, Turkey
e-mail: rceven@uludag.edu.tr
Corresponding author:
GÜNAYDIN KARAKAN GIZEM
e-mail: ggunaydin@pau.edu.tr

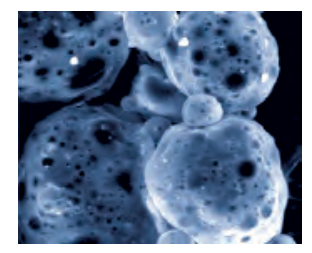




\section{Characterization of the impact and post impact (CAl) properties of 3D-structure composites}

DOI: $10.35530 / I T .068 .06 .1570$

REZUMAT - ABSTRACT

Caracterizarea proprietăților de impact și postimpact (CAI) ale compozitelor cu structură 3D

Răspunsurile la impact sunt o țintă importantă în proiectarea compozitelor avansate deoarece compozitele cu structură $3 D$ integrată sunt adesea folosite în aplicații de rezistență la impact. Această lucrare prezintă un nou tip de compozite $3 D$ realizate din tricot de urzeală. Cinci tipuri diferite de tricoturi din urzeală, cu parametrii structurali diferiți, de exemplu structura stratului exterior, finețea firelor și unghiul de înclinare a firului au fost implicate în producerea compozitelor. Pentru a analiza comportamentele la impact și postimpact (CAl) ale compozitelor și efectul fiecărui parametru structural, s-au efectuat testele de impact și compresiune după impact. Rezultatele indică faptul că parametrii structurali ai materialului pot influența în mod evident performanța la impact a compozitelor, iar după impact, compozitele au capacități de amortizare favorabile care pot satisface cererea de utilizare finală.

Cuvinte-cheie: structura 3D, parametrii structurali, proprietăți de impact, comportamente CAI

\section{Characterization of the impact and post impact (CAI) properties of 3D-structure composites}

Impact responses are important target in designing advanced composites because composites with integrated $3 D$ structure are often used in impact-resistance applications. This paper considers a new type of 3D composites made from warp-knitted spacer fabric. Five different types of warp-knitted spacer fabrics with different structural parameters, e.g. outer layer structure, fineness of spacer yarn and inclination angle of spacer yarn, were involved to produce the composites. To analyze the impact and post impact (CAl) behaviors of composites and the effect of each structure parameter, the impact and compression-after-impact tests were conducted. The findings indicate that the fabric structural parameters can obviously influence the impact performance of composites and the composites after impact retain favorable cushioning capacities which can satisfy the end-use application.

Keywords: $3 D$ structure, structural parameters, impact properties, CAI behaviors

\section{Introduction}

The structural composites are determined that the material system consisting of two or more elements on a macroscopic scale, whose mechanical properties and responses are designed to be superior than those of the constituent materials acting independently [1]. Light-weight construction, high stiffness and high strength, from the economical points of view, is of particular importance in the range of modern industrial systems for cushioning applications [2]. Composites with integrated 3D structure offer the great potential to be used in impact-resistance applications, since they combine low weight with high anti-impact abilities and their delamination resistant abilities are also preferable [3-4]. In these circumstances, the integrated 3D-structurecomposites are widely used for automobiles, vehicles, marine and so on.

Some researches have investigated on the impact and compression after impact (CAI) behaviors of 3D-structurecomposites. Velosa et al. [5] studied some effect factors, that is, cross-thread density, fineness of yarns and structure of face of fabrics, as well as thickness of fabrics, on the mechanical behaviors (compression and low-velocity impact responses) of novel sandwich composite panels made of 3D-knitted spacer fabrics. Thermoplastic composites based on flat warp-knitted 3D multilayer spacer fabrics have been introduced by Abounaim [6]. It can be concluded from their studies that the mechanical responses of these composites are significantly influenced by the arrangement of reinforced yarns and the integration of reinforced yarns with biaxial inlays are found to be the optimum method. The obtained results indicate that the 3D-structure composites are usually made from spacer fabrics as reinforcement materials, consisting of two separate faces connected by spacer yarns.Additionally, the mechanical properties of warp-knitted spacer fabriccomposites can also be tailored to meet the specific applications by simply varying the fabric structural parameters [7]. Compression after impact (CAI) properties performance represents an important design criterion because it can study the impact-damage-tolerance of composites after suffering impact loading. Lots of published papers revealed that composites with 3D structure endow high CAI strength owing to the capacity of reduction of impact energy [8-10]. The 3D-structure composites charactered for impact and CAI responses involved in this study possessa flexiblestructure, which is quite different from the compositesmade with stiff surfaces as shown in literatures. These novel integrated 3D-strucutre composites are made from warp-knitted spacer fabrics, consisting of two separate faces 


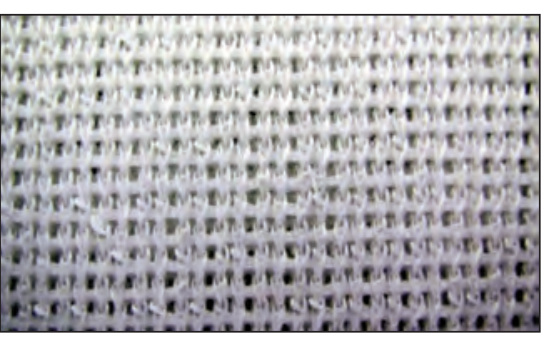

a

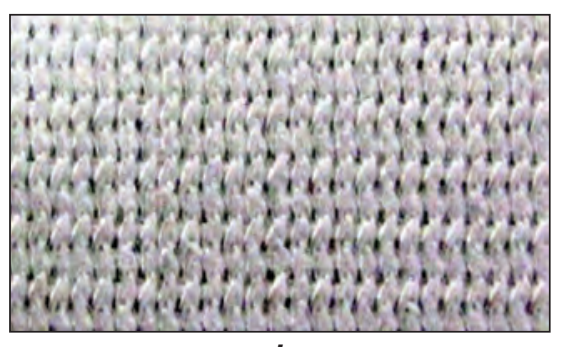

b

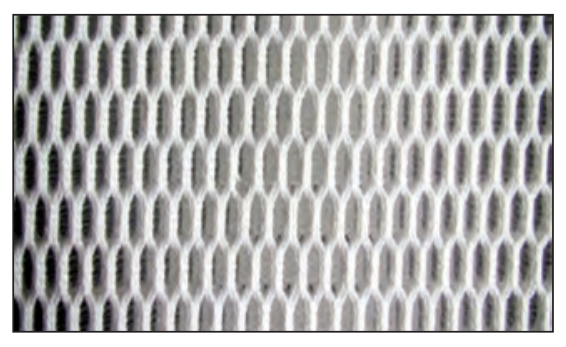

c

Fig. 1. The surface layer structures: $a-C h a i n+I n l a y ; ~ b-$ Locknit; $c-$ Hexagonal Mesh

\begin{tabular}{|c|c|c|c|c|}
\hline Code & $\begin{array}{c}\text { Thickness } \\
(\mathbf{m m})\end{array}$ & $\begin{array}{c}\text { Surface layer } \\
\text { structure }\end{array}$ & $\begin{array}{c}\text { Table } 1 \\
\text { Diameter of } \\
\text { spacer yarn } \\
\mathbf{( m m )}\end{array}$ & $\begin{array}{c}\text { Spacer yarn } \\
\text { inclination angle } \\
\text { (degree) }\end{array}$ \\
\hline WSF1 & 7.46 & Chain+lnlay & 0.2 & 80 \\
\hline WSF2 & 7.44 & Chain+lnlay & 0.16 & 65 \\
\hline WSF3 & 7.42 & Chain+lnlay & 0.2 & 65 \\
\hline WSF4 & 7.42 & Hexagonal Mesh & 0.2 & 80 \\
\hline WSF5 & 7.44 & Locknit & 0.2 & 80 \\
\hline
\end{tabular}

connected by spacer yarns. It is expected that a regular pattern for tailoringthe composites with favorable impact and CAlperformance could be found from this study.

\section{EXPERIMENTAL DETAILS}

\section{Samples}

\section{Warp-knitted spacer fabrics}

Five types of warp-knitted spacer fabrics (hereinafter referred to briefly asWSF) have been produced on a double-needle-bar Raschel warp knitting machine of E18 (Wuyang CO. LTD, Jiangsu, China). The PET monofilament of $0.2 \mathrm{~mm}$ and $0.16 \mathrm{~mm}$ in diameter were used for spacer yarns, while 300D/96F PET multifilament were used as outer layer yarns. Three surface structures, Chain+Inlay, Locknit and Hexagonal Mesh of spacer fabrics were chosen for this investigation, as shown in figure 1. According to their shapes, the outer layer structures can be dived into two categories: the close structure without mesh (Chain+Inlay and Locknit) and open structure with mesh (Hexagonal Mesh). In addition, it can be revealed that Locknit is slightly closer than Chain+ Inaly [7]. Also, two inclination angles of spacer yarn were involved for fabricating the spacer fabrics. The resultant details of spacer fabrics are listed in table 1. The actual thickness of fabrics is slightly different due to the deviation of knitting machine. However, all the fabrics were nearly $7.4 \mathrm{~mm}$, thus, it can be considered that the thickness of these fabrics were close to each other.

\section{Fabrication of composites}

The composites (hereinafter referred to briefly as PWSF, e.g. the composite PWSF1 was manufactured with WSF1, and so on) were produced by impregnating the warp-knitted spacer fabrics with a

\begin{tabular}{|l|c|}
\hline \multicolumn{1}{|c|}{ Property } & Table 2 \\
\hline Density $\left(\mathrm{g} / \mathrm{cm}^{3}\right)$ & Values \\
\hline Tensile modulus $(\mathrm{kpa})$ & 0.15 \\
\hline Elongation at break $(\%)$ & 89.8 \\
\hline Compression strength $(\mathrm{kpa})$ & 147.5 \\
\hline Compression modulus $(\mathrm{kpa})$ & 58.7 \\
\hline
\end{tabular}

Table 3

\begin{tabular}{|l|c|c|c|}
\hline Sample & $\begin{array}{c}\text { Thickness } \\
(\mathbf{m m})\end{array}$ & $\begin{array}{c}\text { Fiber volume } \\
\text { fraction } \\
(\mathbf{\%})\end{array}$ & $\begin{array}{c}\text { Density } \\
\left(\mathbf{K g} / \mathbf{m}^{3}\right)\end{array}$ \\
\hline PWSF1 & 7.72 & 7.33 & 266.3 \\
\hline PWSF2 & 7.76 & 6.32 & 250.3 \\
\hline PWSF3 & 7.66 & 6.57 & 249.7 \\
\hline PWSF4 & 7.86 & 2.25 & 249.2 \\
\hline PWSF5 & 7.82 & 8.25 & 284.1 \\
\hline
\end{tabular}

flexible polyurethane foam, consisting of a mix of $1.21 \mathrm{~g} / \mathrm{cm}^{3}$ isocyanate and $0.78 \mathrm{~g} / \mathrm{cm}^{3}$ polyol, in a 43.7/100 isocyanate-polyol mixing ratio (by weight) (BASF, PuDong Site, Shanghai, China). The important properties of this polyurethane foam are listed in table 2. Production of the composite samples was carried out in a mould of which top and bottom surfaces can be heated by a water bath heating system. The isocyanate-polyol mixing liquid was infused through the core of spacer fabrics in the warp direction. At the same time, the water temperature was maintained at $40^{\circ}$ during the infusion process which was carried out for $8 \mathrm{~min}$, in order to maintain the cured polyurethane foam. After foaming, all the specimens were placed for 24 hours at room temperature, 


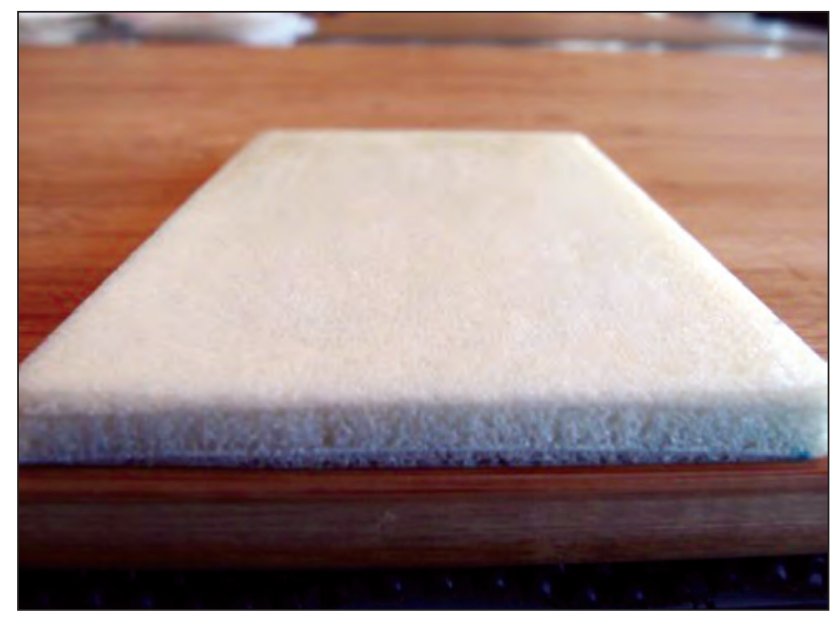

Fig. 2. The real view of PWSF

until the polyurethane foam wasstable. The five types of composites produced are provided in table 3 and the real view and schematic diagram of produced composites are shown in figure 2.

\section{Impact tests}

Impact properties of the composites were evaluated using an Instron Dynatup 9250HV according to GB/T8171-2008 test standard, as shown in figure 3. An impactor having diameter of $25 \mathrm{~mm}$ with a flat tip was used to hit against the face of specimens $(100 \mathrm{~mm} \times 100 \mathrm{~mm})$. The weight of the impactor is $6.017 \mathrm{~kg}$. The impactor should be given a initial velocity which can be calculated in incident impact energy by Kinetic energy formula. The incident impact energy used for work was $10 \mathrm{~J}$ and $15 \mathrm{~J}$, respectively. For each composite, three samples were tested and the ultimate result was the average of the three tests.

\section{Compression tests}

All of the impacted specimens were conducted the compression-after-impact test by using Shanghai HL WDW SERIES material test instrument, and the test was done at $23^{\circ}$ and $65 \%$ relative humidity based on GB/T8168-2008 test standard. The size of compression platen is $\Phi=50 \mathrm{~mm}$, which is slightly larger than the diameter of impactor. The samples were pressed to a deformation with $60 \%$ of the initial thickness at a load speed of $5 \mathrm{~mm} / \mathrm{min}$ and five repeats were carried out for each specimen.

\section{RESULTS AND DISCUSSIONS}

\section{Impact tests}

With the aim of investigating the effect of fabric structural parameters on the impactresponses, the forcedisplacement curves conducted at impact energy $10 \mathrm{~J}$ and $15 \mathrm{~J}$ for all the five samples are shown in figure 4 . Referring to figure 4 , it can be found that the curves are bound to change with the changes of incident energy values. The maximum displacement (at peak force) increases whilethe contact duration time

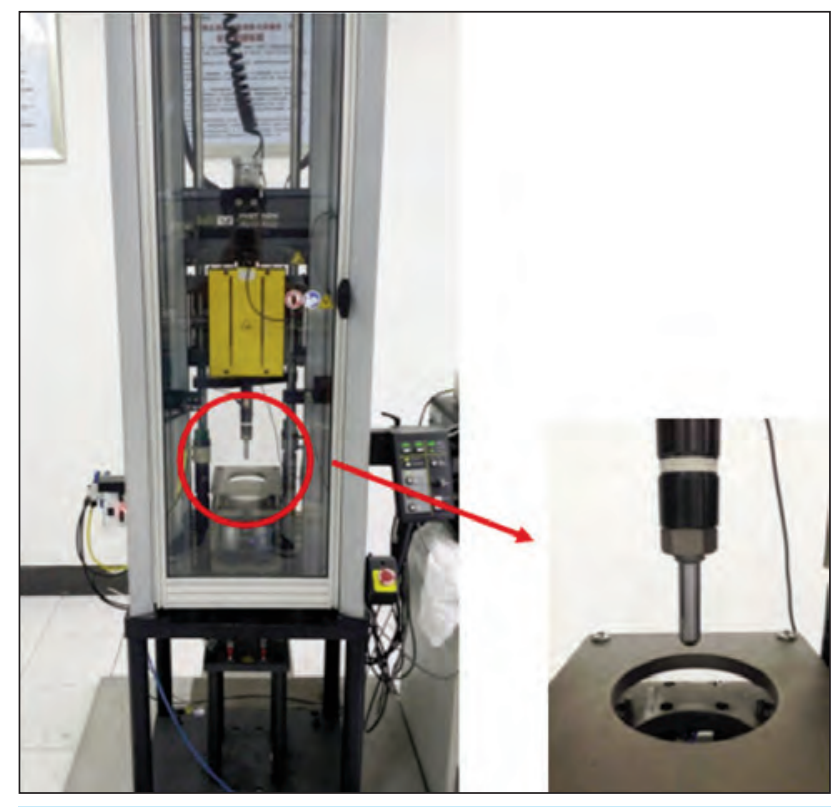

Fig. 3. The Impact instrument

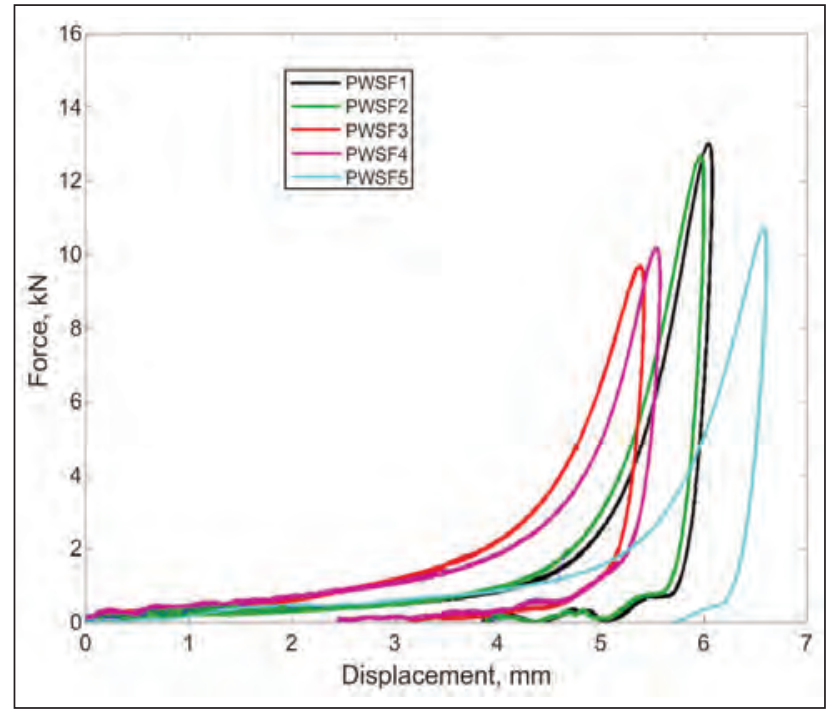

a

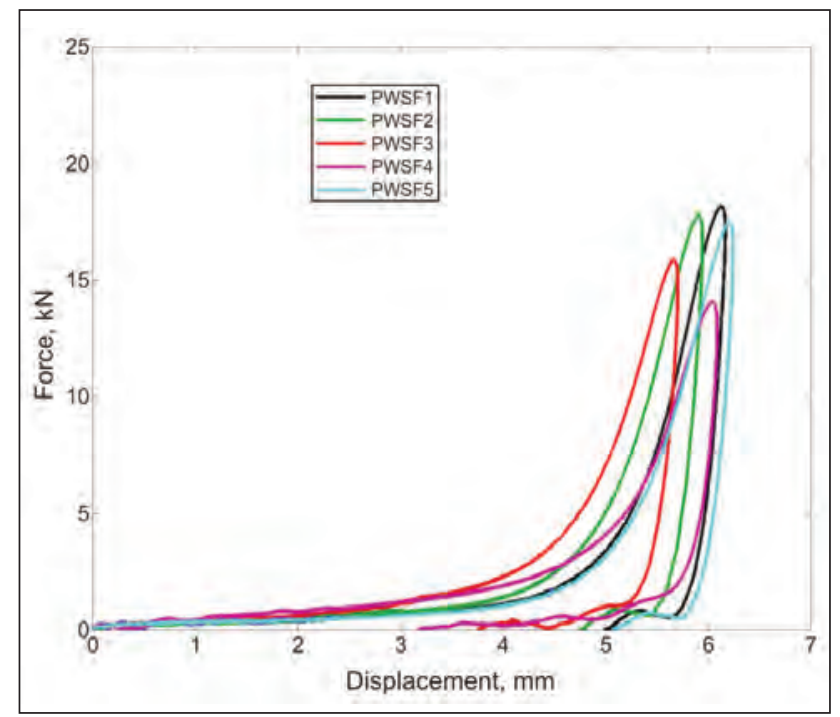

b

Fig. 4. The force-displacement curves of PWSF under impact energy $10 \mathrm{~J}(a)$ and $15 \mathrm{~J}(b)$ 
decreases with the increase of impact energy. Force drops significantly and displacement declines to some position in the unloading stage. This demonstrates that the loading stage (the displacement before peak force) is an important factor for energy-absorbing behaviors, since the force values are nearly constant while the displacement increases in this stage. The absorbed energy can be illustrated by the area under the impact force-displacement curves [7]. For different composites conducted to the same impact energy, an ideal energy-absorber is considered to absorb as much energy as possible, indicating that the loading stage should be as long as possible [11].

The composites PWSF1, PWSF4 and PWSF5have the same fineness and inclination angle of spacer yarn. It can be seen that the peak force of PWSF1 and PWSF5 arenearly the same and significantly higher than that of PWSF4, indicating that composites with close outer layer structures obtain superior anti-impact properties as compared to the composite with open outer layer structure. The better impact properties of composites PWSF1 and PWSF5 are due to much closer outer layer structures which can absorb more impact energy. PWSF2 and PWSF3 show the composites with the same inclination angle of spacer yarnbut different spacer yarns'diameters ( $0.16 \mathrm{~mm}$ and $0.2 \mathrm{~mm}$, respectively). It is found that composite made from finer spacer yarn endow the superior impact resistance abilities and can absorb more impact energy than that of coarser spacer yarn. The preferable impact performance of composite with finer spacer yarn is due to the high volume fraction of polyurethane foam matrix which absorbs more energy during impact loading. PWSF1 and PWSF3 represent the composites with different inclination angle of spacer yarn. Referring to figure 4, it is evident that the composite with larger inclination angle of spacer yarn exhibits higher peak force, resulting in better antiimpact behaviors for composite made from larger inclination spacer yarn angle. Additionally, the loading stage for composite made from smaller angle of

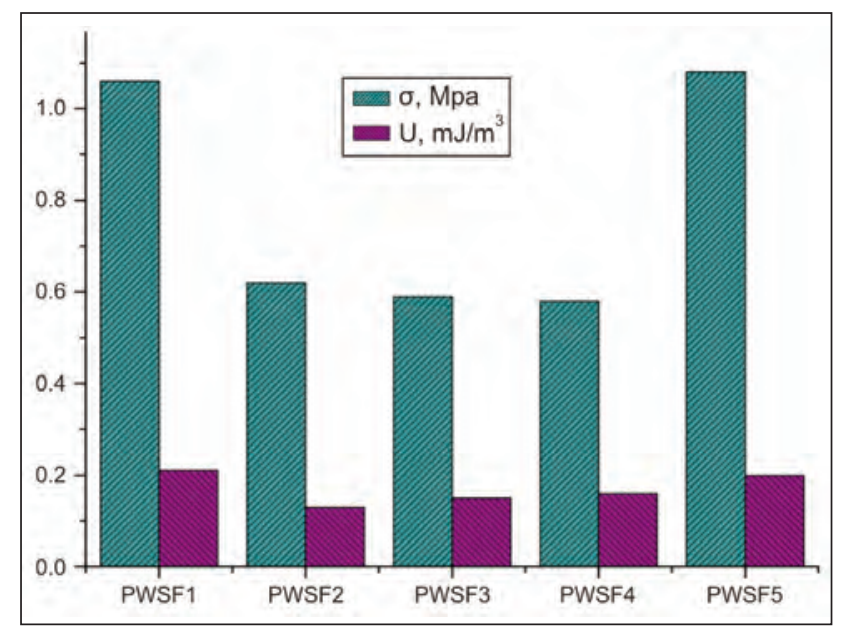

Fig. 5. The compression modulus and energy absorption spacer yarn is shorter than that of composite made with larger angle of spacer yarn, which leads to adecrease of energy absorbed for composite with smaller spacer yarn angle.

\section{Post impact (CAI) tests}

All the samples were conducted for compression behaviors before impact tests. Figure 5 presents the compression modulus $(\sigma)$ and energy absorption $(U)$ of five composites during the compression process. From the figure, it is revealed that PWSF1 and PWSF5 obtain the highest compression modulus as compare to the other three composites and PWSF5 has a slightly higher modulus than that of PWSF1, indicating that composites with closer surface structure and larger inclination angle of spacer yarn could obtain superior compression resistance abilities. Although the inclination angle of PWSF4 is same as PWSF1, its out layer structure is opener, resulting in a poorer anti-compression performance. It can also be seen that the compression modulus of PWSF2 and PWSF3 are similar, demonstrating that the effect of diameter of spacer yarn on the compression properties is not obvious. Referring to figure 5 , the energy absorption condition has the same tendency with thediscipline of compression modulus.

The impacted composites were characterized for the CAI properties. The compression curves (before impact and after impact) of PWSF3 is taken as a representative of five samples, as shown in figure 6 . It is obvious that the compression resistance abilities of composites are lower when suffering impact loading. Furthermore, with the increasing of impact energy, the anti-compression performance decreases.

Figure 7 shows the compression modulus of five composites before impact and after suffering two different impact energies. It is observed that the compression modulus decreases as the impact energy increases. The larger impact energy, the more compression modulus loss. In order to better investigate

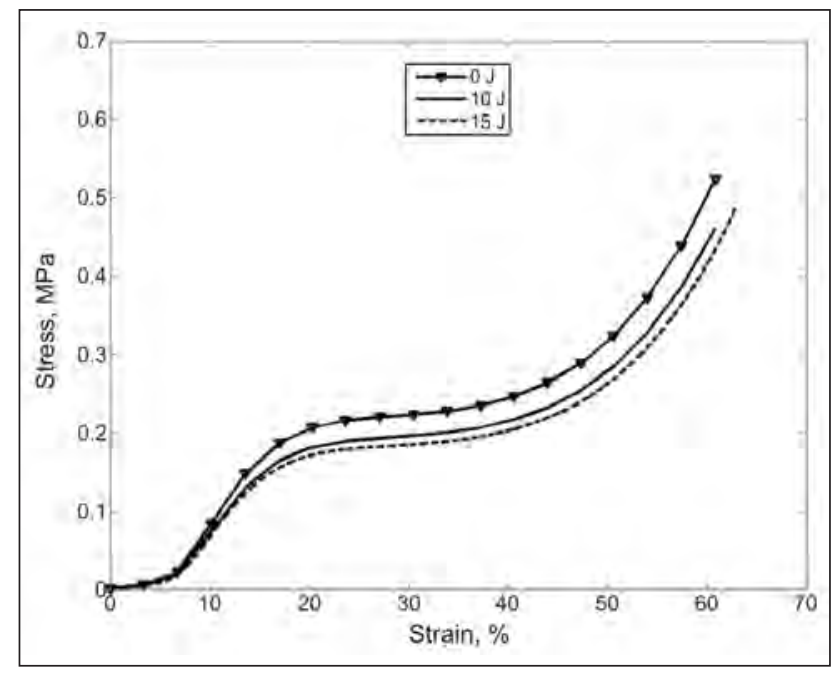

Fig. 6. The compression curves before impact and after impact 


\begin{tabular}{|c|c|c|c|c|c|}
\hline \multirow{2}{*}{ Code } & \multirow{2}{*}{$\begin{array}{c}\text { Compression modulus } \\
(\mathbf{M P a})\end{array}$} & \multicolumn{2}{|c|}{$\begin{array}{c}\text { Compression modulus after impact } \\
(\mathbf{M P a})\end{array}$} & \multicolumn{2}{|c|}{$\begin{array}{c}\text { Compression modulus loss rate } \\
(\%)\end{array}$} \\
\cline { 3 - 6 } & & $\mathbf{1 0 ~} \mathbf{~}$ & $\mathbf{1 5} \mathbf{~ J}$ & $\mathbf{1 0 ~ J}$ & $15 \mathbf{J}$ \\
\hline PWSFC1 & 1.02 & 0.82 & 0.79 & 19.61 & 22.55 \\
\hline PWSFC2 & 0.61 & 0.54 & 0.49 & 11.48 & 19.67 \\
\hline PWSFC3 & 0.59 & 0.51 & 0.47 & 13.56 & 20.34 \\
\hline PWSFC4 & 0.58 & 0.53 & 0.48 & 8.62 & 17.24 \\
\hline PWSFC5 & 1.04 & 0.86 & 0.83 & 17.31 & 20.19 \\
\hline
\end{tabular}

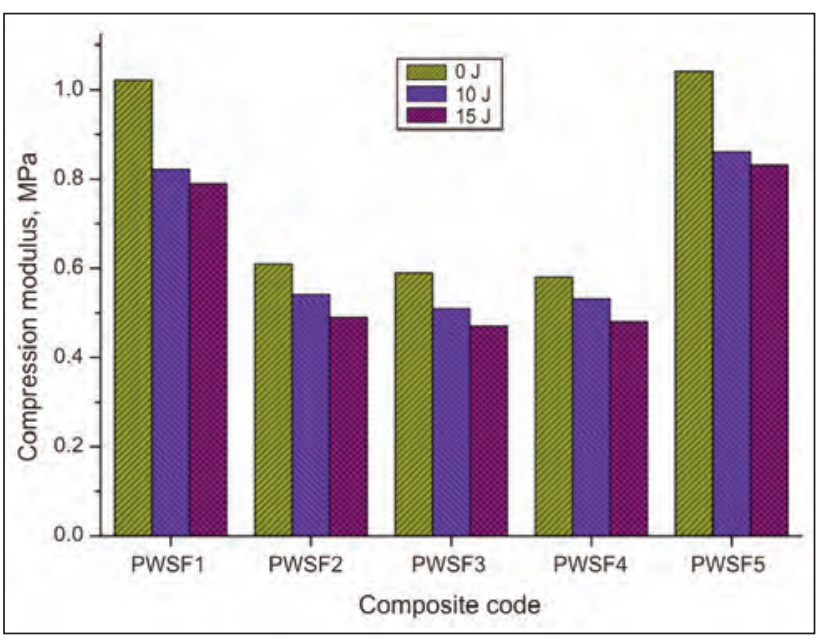

Fig. 7. The compression modulus before impact and after impact

the compression modulus lost condition, the compression modulus loss rate $(\lambda)$ was involved. The compression modulus loss rate can be calculated by the following equation:

$$
\lambda=\frac{\sigma_{\mathrm{C}}-\sigma_{\mathrm{P}-\mathrm{C}}}{\sigma_{\mathrm{C}}}
$$

where:

$\lambda$ is compression modulus loss rate;

$\sigma_{\mathrm{C}}$ - the compression modulus;

$\sigma_{\mathrm{P}-\mathrm{C}}-$ the compression modulus after impact.

According to equation (1), the compression modulus loss rate for all the composites after impact is listed in table 4. It is seen that the composites having higher compression modulus (PWSF1 \& PWSF5) can retain more modulus when suffering impacting loading. However, PWSF4 has the lowest compression modulus loss rate due to its open outer layer structure which can change more impact energy into structural damage. The compression modulus loss rates of all the composites are around $20 \%$ under impact energy of $15 \mathrm{~J}$ which indicates that the cushioning capacity of composites can be maintained after suffering impact loading.

\section{CONCLUSIONS}

In this paper, a new type 3D composites reinforced by warp-knitted spacer fabrics was successfully manufactured. The impact and post impact (CAI) properties were evaluated. The impact tests were carried out in $10 \mathrm{~J}$ and $15 \mathrm{~J}$, respectively. The concluding remarks were summarized as follows:

- The composites with close outer layer structures obtain superior anti-impact properties as compared to the composites with open outer layer structure. While the composites made fromfiner spacer yarn endow higher peak forceand longer loading stage as compared to the composites with coarser spacer yarn. It is demonstrated that composites made from finer spacer yarn endow the superior impact resistance abilities. The composites with larger inclination angle of spacer yarn exhibits favorable anti-impact behaviors.

- The CAI properties of composites were also investigated. It is found that the compression modulus decrease when suffering impact loading. Furthermore, the larger impact energy, the more decrease of compression modulus. However, the composites after impact could retain ideal cushioning abilities which can meet the requirement of end-use application.

\section{ACKNOWLEDGEMENT}

This work was supported by The Foundation of Inner Mongolia University of Technology ZD201620 and The Foundation of Inner Mongolia University of Technology X201232.

\section{BIBLIOGRAPHY}

[1] Morel, A., Bedek, G., Dupont, F. S. D. Impact and post impact (CAl) behavior of stitched woven-knit hybrid composites. In: Composite Structures, 2014, vol. 116, no. 9, p. 243.

[2] Hahn, M., Otto, A. Hoch temperature-umforming von zellularemaluminium. Metallschaume, H. P. Degischer (Ed), Wiley-VCH, 2000, pp. 432-35.

[3] Chen, S., Long, H.R. Investigation on compression properties of polyurethane-based warp-knitted spacer fabric composites for cushioning applications Part II: theoretical model and experimental verification. In: Industria Textila, 2014 , vol. 65 , no. 6 , p. 340. 
[4] Coterlici, R.F. Study regarding the use of a cotton fiber reinforced composite for obtaining protection helmets. In: Industria Textila, 2016, vol. 67, no. 2, p.135.

[5] Velosa, J.C., Rana, S., Fangueiro, R., et al. Mechanical behavior of novel sandwich composite panels based on 3D-knitted spacer fabrics. In: Journal of Reinforced Plastics and Composites, 2011, vol. 31, no. 2, p. 95.

[6] Abounaim, M., Hoffmann, G., Diestel, O. et al. High performance thermoplastic composite from flatknitted multi-layer textile perform using hybrid yarn. In: Composite Science and Technology, 2011, vol. 71, p. 511.

[7] Chen, S., Long, H., Liu, Y., et al. Mechanical properties of 3D-structure composites based on warp-knitted spacer fabrics. In: Autex Research Journal, 2015, vol. 15, no. 2, p. 127.

[8] Wang, B., Wu, L. Z., Ma, L., et al. Low-velocity impact characteristics and residual tensile strength of carbon fiber composite lattice core sandwich structures. In: Composites Part B Engineering, 2011, vol. 42, no. 4, p. 891.

[9] Hisaya, Katoh, Toshiyuki, Shimokawa, Akira, Ueda, et al. Impact damage and CAl strength of MR50K/PETI5 carbon/tough-polyimide composite at room and high temperatures. In: Advanced Composite Materials, 2005, vol. 14, no. 2, p. 211.

[10] Perillo, G., Jørgensen, J.K. Numerical/experimental study of the impact and compression after impact on GFRP composite for wind/marine applications. In: Procedia Engineering, 2016, pp. 129-137.

[11] Mehment, K., Hakan, Gul, Jan, Ivens et al. Low velocity impact characteristics of integrated $3 D$ core sandwich composite. In: Textile Research Journal, 2012, vol. 82, no. 9, p. 945.

\author{
Authors: \\ SI CHEN \\ XIAO-QING WANG \\ College of Light Industry and Textile \\ Inner Mongolia University of Technology \\ Hohhot, Inner Mongolia 010080, China \\ Corresponding author: \\ XIAO-QING WANG \\ e-mail: ansn9119@126.com
}




\title{
The effects of open porosity and constructional parameters on cotton woven fabric's ultraviolet protection factor
}

\section{REZUMAT - ABSTRACT}

\section{Efectele porozității deschise și ale parametrilor de construcție asupra factorului de protecție} la ultraviolete al țesăturilor

\begin{abstract}
Lucrarea prezintă rezultatele cercetărilor cu privire la efectul structurii țesăturilor de bumbac de culoare deschisă asupra factorului de protecție la ultraviolete (UPF). Tipul de legătură, densitatea absolută a țesăturii și densitatea relativă a țesăturii au fost luate în considerare pentru a defini efectul structurii țesăturilor asupra UPF. Pentru a stabili o relație cantitativă între structura țesăturii și UPF, porozitatea deschisă a fost utilizată ca un parametru care definește combinațiile dintre parametrii de construcție al țesăturii. În acest studiu s-au utilizat țesături în stare brută (țesături de culoare ecru, maro deschis), și țesături albite și calandrate (țesături albe) realizate din fire scurte de bumbac $100 \%$. Țesăturile de culoare ecru au fost construite cu diferite tipuri de legături (pânză, $2 \times 2$ diagonal, $1 \times 4$ atlas), la trei niveluri diferite de densitate relativă a țesăturii (aproximativ 60\%,70\% și 80\%), în timp ce țesăturile albite au fost create cu legătură pânză, $2 \times 2$ diagonal și $2 \times 2$ legătură tip rogojină, cu aceeași densitate a urzelii și densitate diferită a bătăturii (15, 19, 23 și 29 fire de bătătură/cm). Rezultatele au demonstrat că porozitatea deschisă mai mică duce la o protecție mai bună la ultraviolete. Efectul legăturii este evident numai atunci când probele sunt comparabile la densitatea relativă a țesăturii. O densitate absolută mai mare a țesăturii înseamnă și protecție superioară la UV. Mai mult decât atât, rezultatele indică, de asemenea, valori ale porozității deschise și ale densităților țesăturilor prin care țesătura atinge o bună protecție UV (UPF = 15) - și astfel acestea pot fi utilizate ca recomandări pentru inginerii textiliști la dezvoltarea unui nou tip de structură a țesăturii care să includă protecție adecvată la UV.
\end{abstract}

Cuvinte-cheie: radiații ultraviolete, protecție UV, construcția țesăturii, porozitate deschisă

\section{The effects of open porosity and constructional parameters on cotton woven fabric's ultraviolet protection factor}

The paper presents the results of research dealing with the effect of fabric construction on the ultraviolet protection factor (UPF) of light coloured cotton woven fabrics. The type of weave, absolute fabric density, and relative fabric density were taken into account to define the effect of fabric construction on UPF. To establish quantitative relationship between the fabric construction and UPF, the open porosity was used as a parameter which defines the woven fabric constructional parameter's combinations. Fabrics in a raw state (loomstate, light brown fabrics), along with bleached and calendared fabrics (white fabrics) made from $100 \%$ cotton staple-fibre yarns were used in this research. Loomstate fabrics were constructed with different types of weaves (plain, $2 \times 2$ twill, $1 \times 4$ satin), at threedifferent levels of relative fabric density (around $60 \%, 70 \%$ and $80 \%$ ), while bleached fabrics were constructed in plain, $2 \times 2$ twill, and $2 \times 2$ mattweave, with the same warp density and different weft density at four different levels $(15,19,23$, and 29 picks $/ \mathrm{cm})$. The results clearly indicate that lower open porosity leads to better ultraviolet protection. The effect of weave is evident only when samples are comparable in fabric relative density. Higher absolute fabric density also means superior UV protection. Moreover, the results also indicate the values of open porosity and fabric densities by which the fabric achievesgood UV protection (UPF=15) - and in this way, they can serve as guidelines for fabric engineers when developing a new type of fabric construction that encompasses sufficient UV protection ability.

Keywords: ultraviolet radiation, UV protection, woven fabric construction, open porosity

\section{INTRODUCTION}

Sunburns (erythema), tanning (pigment darkening), premature aging of the skin, suppression of the immune system, damage to the eyes, and skin cancer, are today's well known negative effects that excessive exposure to ultraviolet radiation (UV-A, UV-B, and UV-C) has on human health [1, 2]. Personal protection, provided by clothing, is one of the simplest and best means of sun protection, albeit for personal protection, the use of sunscreen, sunglasses, umbrellas, hats, etc.,can also be very helpful [3-6]. The fact is that not all clothing offers sufficient ultraviolet (UV) protection. The UV protection benefits of clothing items mainly depends on its fundamental material, e.g. the type and construction of fabrics used in the making process.Parameters, which influence the levels of UV protection of woven fabrics, can be grouped as follows [7, 8]: 
- yarn constructional parameters (the type of used fibres/filaments, yarn geometry, yarn twist, yarn packing factor);

- fabric constructional parameters: a) primary parameters of fabric geometry (type of weave, yarn fineness, warp/weft density, relative fabric density or fabric tightness), and b) secondary parameters of fabric geometry (cover factor, open porosity/ macroporosity, fabric volume mass, fabric thickness, volume porosity);

- finishing treatments/additives (dye, pigment, delusterant, optical brighteners, UV absorbers);

- maintenance and end-usage relating to the laundering and wearing conditions (stretch, wetness).

In order to achieve the optimal value of fabric UV protection, as well as other end-usage properties of developed fabric constructions, there is a need to understand the effects of aforementioned parameters on UPF (first and foremost), and to understand the effects of constructional parameter's combinations. The ability of fabric to protect humans against UV radiation is expressed by the ultraviolet protection factor (UPF), which in general describes the amount of UV radiation that passes through the fabric. UPF is measuredusing the in vitro or in vivo method. The in vitro method is less time consuming, simple and costeffective, and is based on spectrophotometric measurements of UV transmissions through the fabric. UPF calculation is done by using two weighting factors, namely solar spectral irradiance and erythemal effectiveness. The in vivo method is based on living subjects, and the UPF calculation is done based on the minimal erythemal dose with and without fabric [9]. There are several standards of categorization of fabrics in regards to their UPF value. AS/NZS standard [10] specifies the requirements for determining UPF of sun protective (un-stretched and dry) textiles, garments and other items of personal apparel (hats), which are worn in close proximity to the skin, and appropriate detailed labelling. According to AS/NZS standard, a fabric should transmit no more than $2.5 \%$ of incident UV rays in order to be categorized as a fabric of excellent UV protection.

Woven fabric consists of fibrous material (yarns) and void spaces between the yarns (so called macropores or inter-yarn pores). These pores are exposed to external surface and separated by warp and weft yarns [11]. They allow the transmission of energy and have a direct effect on ultraviolet radiation transmission through the fabric. The amount, size and form of these macro-pores depends on the set of woven fabric constructional parameters, namely the type of weave, type of used threads, yarn fineness and warp/weft density.

The objective of presented research was to understand the role of fabric construction on UPF in the case of light coloured cotton woven fabrics, which are normally used in hot weather conditions due to less absorption of IR radiation. The purpose of this research was also to establish a quantitative relationship between macroporosity structure of woven fabrics, e.g. open porosity, and UPF, in order to give fabric engineers some guidelines whendeveloping fabric constructionsof sufficient UV protection.

\section{MACROPOROSITY STRUCTURE OF WOVEN FABRIC}

Macroporosity structure of woven fabrics can be definedusing an ideal geometrical model (figure 1). The fundamental building element is a macropore, e.g. the empty space between the warp and weft yarns, with a cylindrical shape and a permanent cross-section over all its length (fabric thickness). Macropores have a similar cross-section and uniform distribution over the woven fabric area. In figure 1, the elliptical shape of the macropore cross-section is used to represent the situation in the case of fabrics made from staple-fibre yarns, where: a) the warp density is usually greater than the weft density, and b) the phenomenon of latticed pores occurs due to yarn hairiness, which reduces the macropore crosssection area. Theoretically, the macropores have a rectangular shape of a pore cross-section. Woven fabrics made from staple-fibre yarns have a small percentage of pure pores, some partly latticed pores as well as fully latticed pores. The plain weave includes the maximum percentage of weave passages $(67 \%)$. Therefore, the warp and weft threads are more or less equi-distant and the phenomenon of fully latticed pores is reduced to a minimum. On the other hand, twill and satin weaves include only $33 \%$ and $27 \%$ of weave passages respectively, so the presence of partly and fully latticed pores increases. On the basis of the presented ideal model of macroporosity structure in the form of a tube-like system and the woven fabric constructional parameters (yarn fineness/diameter, warp/weft density), the following macroporosity parameters can be calculated in advance during the development process of new fabrics:

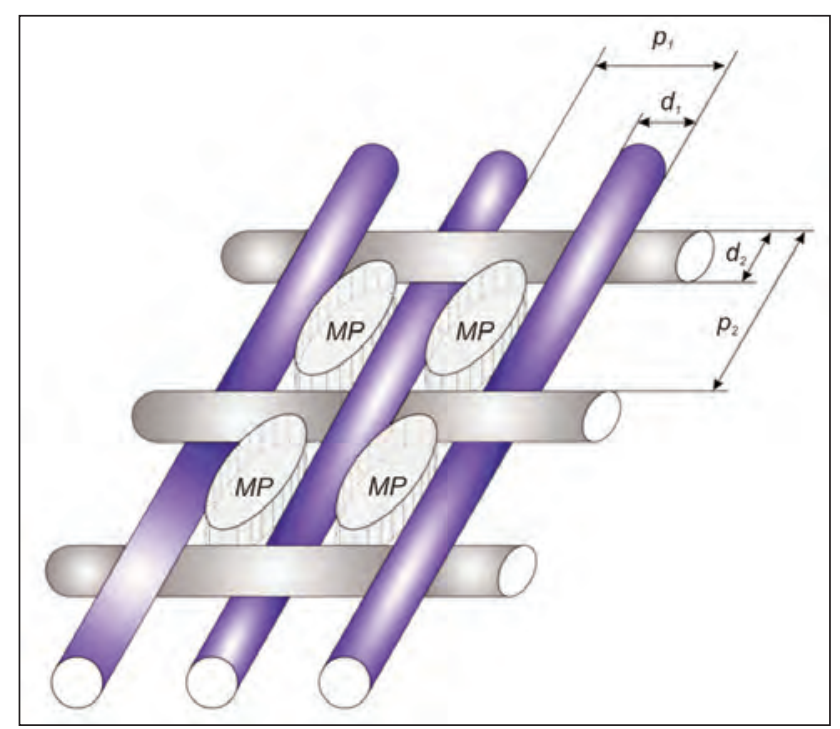

Fig. 1. The ideal geometrical model of woven fabric macroporosity structure:

$d$-yarn thickness, $p$ - yarn spacing, MP - macropore; 1 and 2 indicates warp and weft yarns, respectively 
- macroporosity, which describes the portion of macropore volume in the volume unit of woven fabric. It is defined using equation 1 . The rectangular or elliptical macro-pore cross-section area can be calculated using equations 2 and 3, respectively [11].

$$
\begin{aligned}
& \varepsilon_{\text {macro }}=\frac{V_{p}}{V_{p}+V_{y}}=\frac{A_{p} \cdot D}{p_{1} \cdot p_{2} \cdot D}=\frac{A_{p}}{p_{1} \cdot p_{2}} \\
& A_{p / \text { rect }}=\left(p_{1}-d_{1}\right) \cdot\left(p_{2}-d_{2}\right) \\
& A_{\text {p/ell }}=\frac{\pi \cdot\left(p_{1}-d_{1}\right) \cdot\left(p_{2}-d_{2}\right)}{4}
\end{aligned}
$$

where, $\varepsilon_{\text {macro }}$ stands for macroporosity, $V_{p}$ stands for macropore volume in $\mathrm{cm}^{3}, V_{y}$ is the volume of warp and weft yarns (which refer to a single macropore in $\mathrm{cm}^{3}$ ), $p$ means yarn spacing in $\mathrm{mm}, d$ is the yarn diameter in $\mathrm{mm}, D$ is for woven fabric thickness in $\mathrm{mm}, A_{p}$ is the macropore area in $\mathrm{mm}^{2}$ and subscripts 1 and 2 indicate warp and weft yarns, respectively;

- open porosity (area of macro pore cross-section) describes the fraction of macro-pore cross-section area in the area unit of woven fabrics. If we assume the rectangular or elliptical macro-pore cross-section area, the open porosity is calculated using equations 4 and 5, respectively [11]. In this case the open porosity is equal to macroporosity:

$$
\begin{aligned}
\varepsilon_{\text {open/rect }} & =\frac{A_{p}}{A_{p}+A_{y}}=\frac{\left(p_{1}-d_{1}\right) \cdot\left(p_{2}-d_{2}\right)}{p_{1} \cdot p_{2}} \\
\varepsilon_{\text {open/ell }} & =\frac{A_{p}}{A_{p}+A_{y}}=\frac{\pi\left(p_{1}-d_{1}\right) \cdot\left(p_{2}-d_{2}\right)}{4 p_{1} \cdot p_{2}}
\end{aligned}
$$

Here, $\varepsilon_{\text {open }}$ stands for open porosity, $A_{y}$ for the projection area of warp and weft yarns $\left(\mathrm{mm}^{2}\right), A_{p}$ for the cross-section area of macro-pore $\left(\mathrm{mm}^{2}\right), p$ for yarn spacing $(\mathrm{mm})$, and $d$ for yarn diameter $(\mathrm{mm})$. Subscripts 1 and 2 indicate warp and weft yarns, respectively.

\section{EXPERIMENTAL PART}

\section{Materials and methods}

Two groups of woven fabricsamples, designed for hot weather conditions in light colours, were involved in this research. In the first group nine light beige woven fabrics made from staple-fibre yarns with the fineness of 14 tex in both directions were used. They were produced from $100 \%$ cotton yarns, which were made by a carding procedure on a ring spinning machine. In order to define the effects of constructional parameters only, and to eliminate the influence of finishing processes, the fabrics were in a raw state (loomstate fabrics). The samples were comparable in relative fabric density (fabric tightness). The reason why we selected woven fabrics for relative fabric density is because such fabric constructions are universally used.It is for example impossible to produce plain weave fabric with the warp density of 56 ends/cm, as is the case with satin fabric, because the limit value of plain fabric density is only 43 threads $/ \mathrm{cm}$. Similarly; it is unrealistic to produce satin fabric with the warp density of $38 \mathrm{end} / \mathrm{cm}$, as such fabric construction is simply too loose and not adequate for end-usage. Plain $2 \times 2$ twill and $1 \times 4$ satin fabrics were used in this research at three levels of fabric relative density $(55 \%-65 \%, 65 \%-75 \%, 75 \%-85 \%)$. The Kienbaum's setting theory [12] was used to determine the fabric relative density and weave factor for plain (0.904), twill (1.188), and satin (1.379) fabrics. The constructional parameters of loomstatewoven fabric samples are collected in table 1 (No. 1-9).

In the second group of woven fabrics twelve woven fabrics made from staple-fibre yarns with 14.8 tex fineness (or yarn diameter of $0.125 \mathrm{~mm}$ ) in both directions were used. They were also produced from $100 \%$ cotton yarns, how ever loomstate fabrics were then finally desized, bleached and calendered. These samples were comparable in regards to theabsolute value offabric density. Plain, $2 \times 2$ twill and $2 \times 2$ matt fabrics were prepared using four levels of weft density $(15,19,23$ and 27 picks/cm). Warp density was identical for all samples $(40 \mathrm{end} / \mathrm{cm})$. The constructional parameters of bleached woven fabric samples are collected in table 1 (No. 10-21).

Open porosityof tested samples was calculated theoretically on the basis of equation 4 and equation 5 , where rectangular and elliptical shape of macropore cross-section was taken into account, respectively. For yarn diameter calculation, the value of $1.5 \mathrm{~g} / \mathrm{cm}^{3}$ for fibre bulk density and 0.8 for yarn packing factor was taken into account. The calculated yarn diameter was $0.122 \mathrm{~mm}$ and $0.125 \mathrm{~mm}$ for yarn of 14 and 14.8 tex, respectively. All fabric samples were tested for their warp/weft density value using pick counting glass. The flattened diameter of bleached and calendered fabrics was measured under the Projectina microscope with $100 \times$ magnification after the yarns were unravelled from the fabric.

The UPF of tested samples was determined by:

- in vitro method for samples No. 1-9, according to the AS/NZ standard 4399:1966 using UV-VIS Spectrophotometer Varian Cary 50. The estimated UPF value was the mean UPF value for four testing samples, reduced for the standard error in the mean UPF, and calculated for the $99 \%$ confidence level. The UPF was not rounded down to the nearest multiple of five in order to find out the effect of the constructional parameters on UPF. According to AS/NZ standard, a good UV protection is achieved at the value of UPF 15;

- in vitromethod for samples No. 11-21, in accordancewith the American Association of Textile Chemist and Colorists (AATCC) standard 183-1998, using the SDL measurement system, after conditioning the samples in standard atmosphere. The test was performed by exposing the fabric to UV radiation ( $280 \mathrm{~nm}$ to $400 \mathrm{~nm}$ ) and measuring the transmission through the fabric. According to 
CONSTRUCTIONAL PARAMETERS AND UPF RESULTS OF TESTED WOVEN FABRICS

\begin{tabular}{|c|c|c|c|c|c|c|c|c|c|}
\hline 우 z & 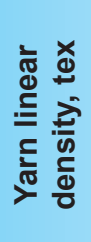 & 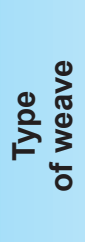 & $\begin{array}{l}\frac{E}{0} \\
\frac{n}{0} \\
\frac{\mathrm{C}}{\mathrm{H}}\end{array}$ & $\begin{array}{l}\frac{E}{0} \\
\frac{0}{0} \\
\frac{v}{\alpha}\end{array}$ & 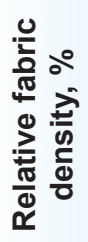 & 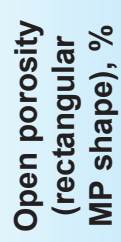 & 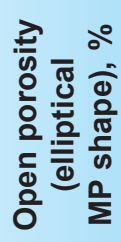 & 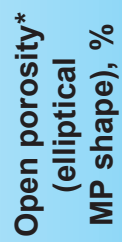 & $\frac{u}{\frac{1}{5}}$ \\
\hline 1 & 14 & plain & 38.7 & 18.2 & 62 & 41 & 32 & - & 4 \\
\hline 2 & 14 & plain & 39.4 & 23.0 & 70 & 37 & 29 & - & 6 \\
\hline 3 & 14 & plain & 39.5 & 32.5 & 84 & 31 & 25 & - & 7 \\
\hline 4 & 14 & twill & 51.1 & 24.0 & 62 & 27 & 21 & - & 9 \\
\hline 5 & 14 & twill & 50.2 & 30.8 & 70 & 24 & 19 & - & 14 \\
\hline 6 & 14 & twill & 51.6 & 39.6 & 80 & 19 & 16 & - & 26 \\
\hline 7 & 14 & satin & 56.9 & 26.5 & 59 & 21 & 15 & - & 16 \\
\hline 8 & 14 & satin & 56.9 & 35.7 & 69 & 17 & 14 & - & 29 \\
\hline 9 & 14 & satin & 57.1 & 46.6 & 79 & 13 & 10 & - & 51 \\
\hline 10 & 14.8 & plain & 40.0 & 15 & 59 & 41 & 32 & 13 & 10 \\
\hline 11 & 14.8 & plain & 40.0 & 19 & 66 & 38 & 30 & 12 & 13 \\
\hline 12 & 14.8 & plain & 40.0 & 23 & 73 & 36 & 28 & 10 & 15 \\
\hline 13 & 14.8 & plain & 40.0 & 27 & 79 & 33 & 26 & 9 & 18 \\
\hline 14 & 14.8 & twill & 40.0 & 15 & 45 & 41 & 32 & 13 & 9 \\
\hline 15 & 14.8 & twill & 40.0 & 19 & 50 & 38 & 30 & 12 & 12 \\
\hline 16 & 14.8 & twill & 40.0 & 23 & 55 & 36 & 28 & 10 & 15 \\
\hline 17 & 14.8 & twill & 40.0 & 27 & 60 & 33 & 26 & 9 & 18 \\
\hline 18 & 14.8 & matt & 40.0 & 15 & 45 & 41 & 32 & 13 & 10 \\
\hline 19 & 14.8 & matt & 40.0 & 19 & 50 & 38 & 30 & 12 & 10 \\
\hline 20 & 14.8 & matt & 40.0 & 23 & 55 & 36 & 28 & 10 & 14 \\
\hline 21 & 14.8 & matt & 40.0 & 27 & 60 & 33 & 26 & 9 & 15 \\
\hline
\end{tabular}

* Calculation with flattened yarns

AATCC standard, the rated UPF is the lowest value of measured UPF rounded to the nearest multiple of 5 . Even so, unrounded values of UPF are still listed in table 1 so that the effect of various parameters can be understood properly.

\section{RESULTS AND DISCUSSION}

The results of calculated open porosity are listed in table 1. Open porosity, calculated upon the equation 5 , where the elliptical shape of macropore cross-section is taken into account, is on average lower by $21 \%$ in regards to the rectangular shape of pore cross-section. The effect of theoretically calculated open porosity on UPF is shown in figure 2. It is evident that lower open porosity leads tohigher UPF values or better UV protection of tested fabrics. This is valid for both groups of tested fabrics, e.g. fabrics in a raw state (loomstate fabrics), as well as bleached fabrics. The correlation between the calculated open porosity and UPF is very high (R-squared 0.95 and 0.88 for loomstate and bleached fabrics, respectively). According to AS/NZ standard, the theoretical (calculated) open porosity of loomstate fabrics should be lower than $19 \%$ in order to achieve good UV protection, regardless of the type of weave. This is

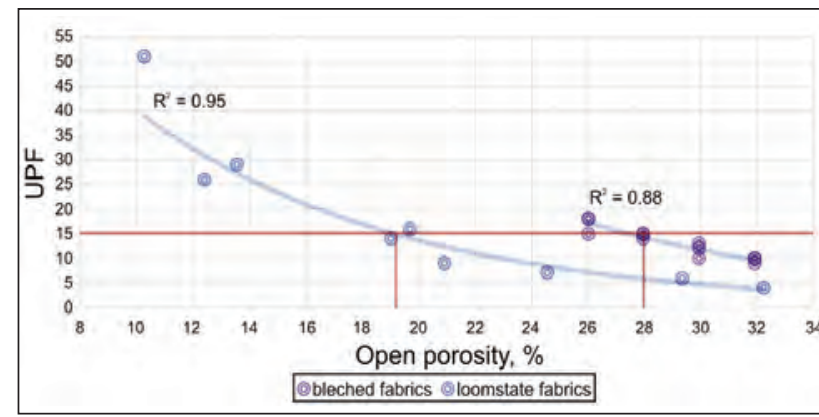

Fig. 2. The influence of open porosity on UPF for tested cotton woven samples

possible exclusivelywith higher fabric densities and definitely not plain fabrics (figure 3 ). In our experiment, plain loomstate fabrics with the lowest porosity (or the highest relative fabric density $-84 \%$, and the highest warp/weft density - 39.5/32.5 threads/cm) did not reach a solid level of UV protection, e.g. the UPF value of 15 . We should also have in mind that real fabrics made from staple-fibre yarn usually have lower open porosity than the theoretical one, because of the phenomenon of latticed pores and thread spacing irregularity. 


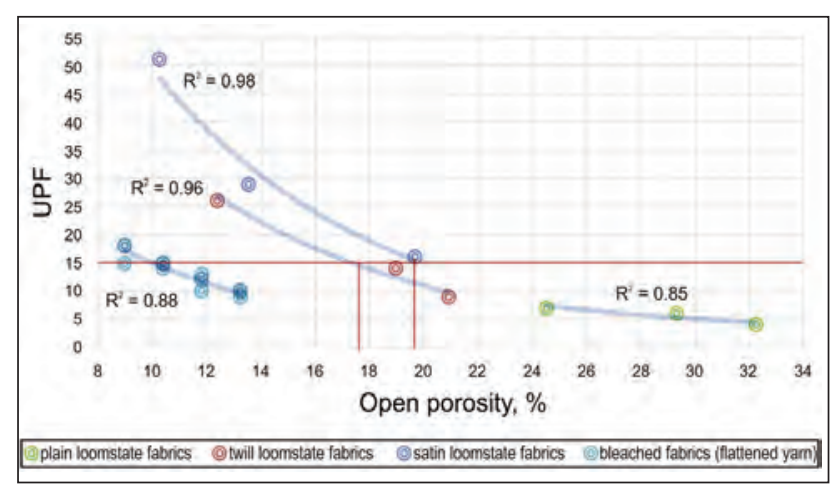

Fig. 3. The influence of calculated open porosity on UPF for tested cotton woven samples regarding the type of weave

Reaching the UPF of more than 15 is possible only for satin fabrics (which are woven at higher densities) and twill fabrics of the highest relative density. The results clearly indicate that the influence of open porosity on UPF should be observed in regards to the type of weave. Twill and satin loomstate fabrics should have open porosity lower than $18 \%$, and $20 \%$ (respectively) to achieve good UV protection. In real woven fabrics, especially in woven fabrics with staple-fibre yarns, different types of pores as a result of the type of weave and other involved factors, are present, which reduce the exposed fabric area in comparison with theoretically calculated values of open porosity. It is worth mentioning that samples were compared according to fabric relative density (fabric tightness). This means that samples with the same fabric tightness had different warp/weft density. For example, in fabric tightness of around $70 \%$, the warp density was 29.4, 50.2, and 56.9 threads/cm for plain, twill, and satin weave, respectively. Higher thread density leads to a smaller pore cross-section area (lower open porosity) - consequently less UV radiation passes through the fabric, which improves the fabric'sability to protect against UV radiation.

Results for bleached fabrics show that most of the tested fabrics did not reach the value of UPF 15 , which indicates a solidlevel of UV protection (figure 2). Only fabrics produced with higher weft density (upper than 23 pick/cm) or open porosity lower than $28 \%$ reached the UPF of at least 15 . The type of weave did not influence the UPF. All three fabrics woven in plain, twill and matt weave had the same levelofopen porosity at particular value of warp and weft densities, and consequently the same effect on UPF, e.g. they hadapproximately the same value of UPF. Also, the ANOVA statistical analysis had shown that the type of weave in this case had no significant effect on UPF. As we concluded before on the basis of tested loomstate woven fabrics, the effect of weave is evident only when samples with the same relative fabric density are compared.

From the figure 2 it can be seen that bleached (white) fabrics have a higher UPF in comparison with loomstate (beige) fabrics at the same level of open porosity (open porosity levels ranging from $26 \%$ to $32 \%$ ).
This, however, is not in accordance to theory. The reason for such results is in the fact that for the calculation of open porosity, the non-deformed shape of yarn cross-section was taken into account (yarn with diameter of $0.122 \mathrm{~mm}$ ), despite the fact that these fabrics were calendered. If we take into account the value of real yarn diameter $(0.191 \mathrm{~mm})$, e.g. the flattened yarn diameter, then the bleached fabrics possess lower UPF in comparison with loomstate fabrics that have the same value of open porosity (figure 3 ). Open porosity was in this case reduced to the range between $9 \%$ to $13 \%$, andin this case, only fabrics produced with open porosity lower than $10 \%$ have reached the UPF at least 15.

Figures 4 and 5 show the effects of relative fabric density and absolute fabric density on UPF, respectively. In figure 5, the results are shown for both type of fabrics (loomstate, bleached) in one diagram, despite the fact that they are not comparable, as they are constructed with different yarn fineness and warp/weft density. The idea is just to show the relationship between absolute density and UPF. Higher relative/absolute fabric density leads to better ultraviolet protection of tested fabrics regardless of the phase of fabric production (loomstate, bleached fabrics). With higher absolute/relative density, the area of macropore cross-section is reduced, consequently less UV rays passes through the fabrics. The ability of fabrics to protect against UV radiation is therefore better.
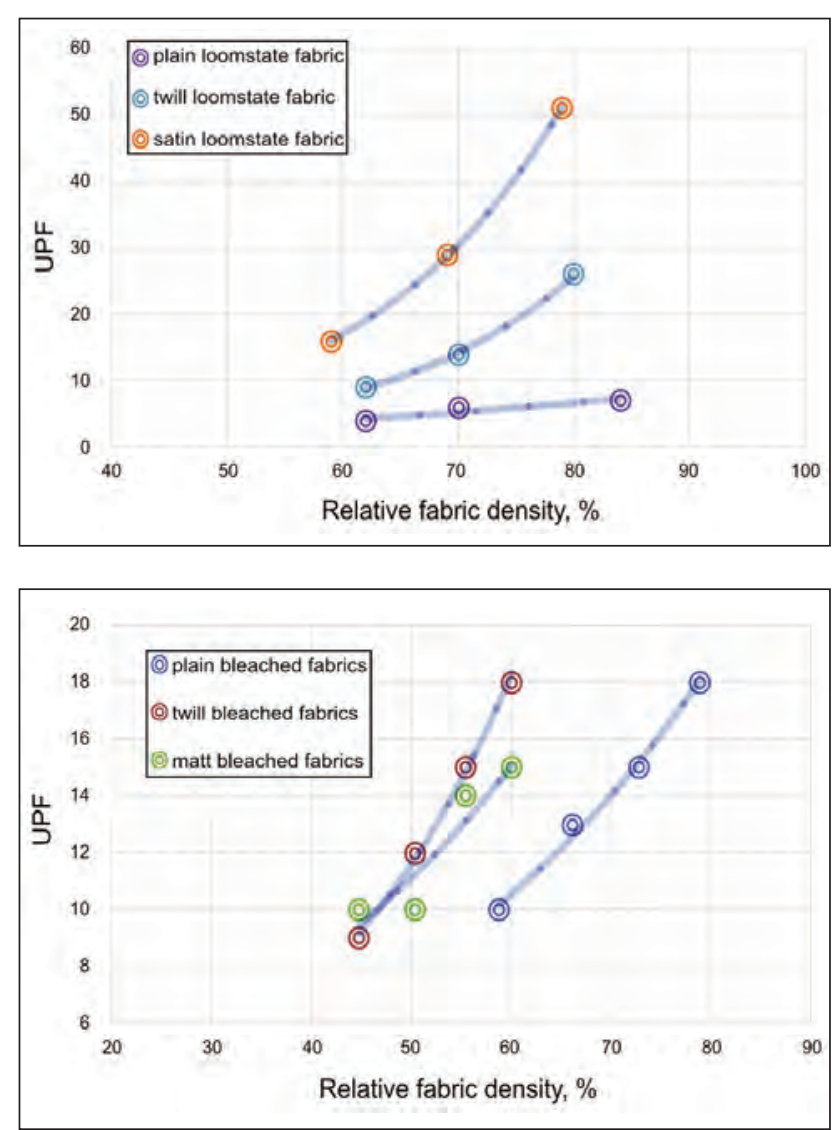

Fig. 4. The effect of relative fabric density on UPF 


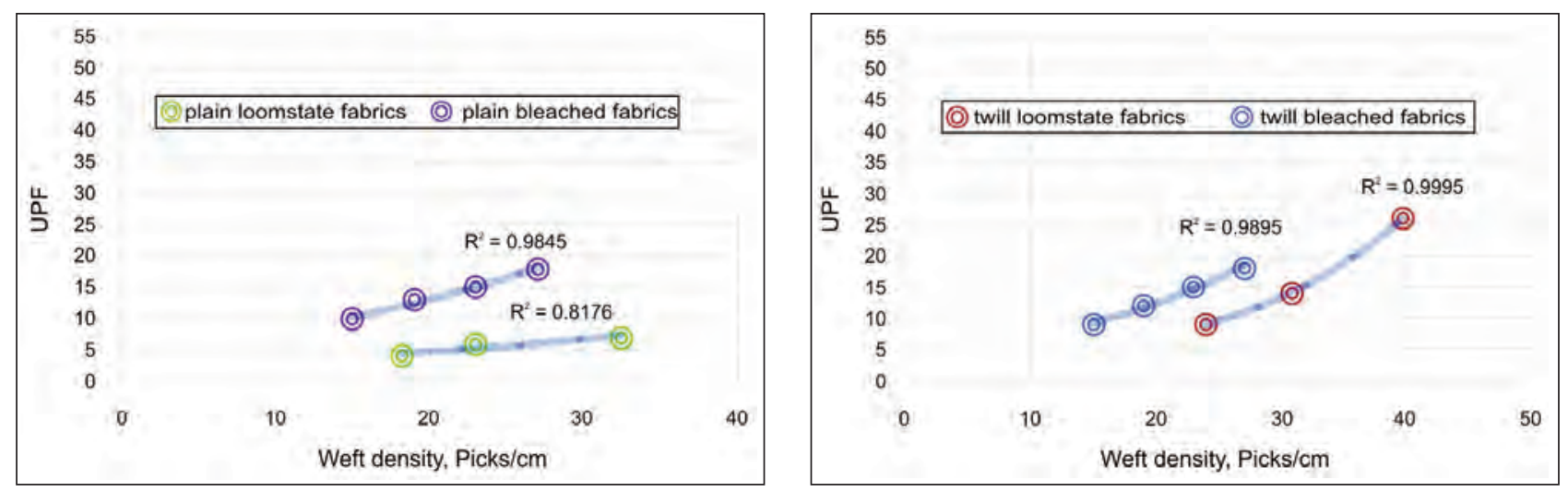

Fig. 5. The effect of absolute fabric density (weft density) on UPF for twill and satin fabrics

\section{CONCLUSIONS}

Woven fabrics as clothing itemsare one of the main products designed for the human body that have the capacity or the ability to resistUV radiation. The ability of fabrics to protect our bodies against UV radiation is determined by the Ultraviolet Protection Factor (UPF). There are several factors influencing the UPF of fabrics. In this study, we focused on the effect of fabric construction on UPF of light colored woven fabrics which are used in hot weather conditions, e.g. type of weave, fabric density (absolute, relative) and open porosity. Two groups of fabrics were used in this research which were comparable in regards torelative fabric density and absolute fabric density. The type of weave has an effect on UPF when samples have a comparable relative fabric density, otherwise the effect is not evident. Higher absolute/relative density and lower open porosity leads to better UPF. The presented diagrams can serve as guidelines for fabric engineers when developing new woven fabric constructionsof sufficient UV protection ability.

\section{BIBLIOGRAPHY}

[1] Cesarini, J.P. Impact of ultraviolet radiation on humans, In: Indoor and Built Environment, 2001, pp. 310-316.

[2] Binkowska, B., Marszalek, R., Sapieja, A., Hernik, T. Protective properties against UV radiation of natural silk textiles, In: Industria Textila, 2015. pp. 19-22.

[3] Roy, C.R., Gies, H.P. The solar UV radiation environment: Measurement techniques and results, In: Journal of Photochemistry and Photobiology B: Biology, 1995, pp. 21-27.

[4] Kullavanijaya, P., Lim, H. W. Photoprotection, In: Journal of the American Academy of Dermatology, 2005, pp. 937-958.

[5] Wang, S.Q., Balagula, Y., Osterwalder, U. Photo-protection: A review of the current and future technologies, In: Dermatologic Therapy, 2010, pp. 31-47.

[6] Gies, P.H., Roy, C. R., Toomey, S., McLennan, A. Protection against solar ultraviolet radiation, In: Mutation Research, 1998, pp. 15-22.

[7] Algaba, I., Riva, A., Pepio, M. Modelization of the influence of the wearing conditions of the garments on the ultraviolet protection factor, In: Textile Research Journal, 2007, pp. 826-835.

[8] Abidi, N., Cabrales, L., Hequet, E. Functionalization of a cotton fabric surface with titania nanosols: Applications for self-cleaning and UV-protection properties, 2009, pp. 2141-2146.

[9] Stanford, D.G., Georgouras, K.E., Paithorpe, M.T. Rating Clothing for sun protection: current status in Australia, In: Journal of the European Academy of Dermatology and Venereology, 1997, pp. 12-17.

[10] AS/NZS 4399, Sun protective clothing - Evaluation and classification, 1966.

[11] Dubrovski, P.D. The Influence of Woven Fabric Geometry on Porosity of Biaxial Fabrics, Doctoral Thesis, Maribor: University of Maribor, Faculty of Mechanical Engineering, 1999.

[12] Kienbaum, M., Gewebegeometrie und Produktenwicklung, In: Melliand Textilberichte, 1990, pp. 737-742.

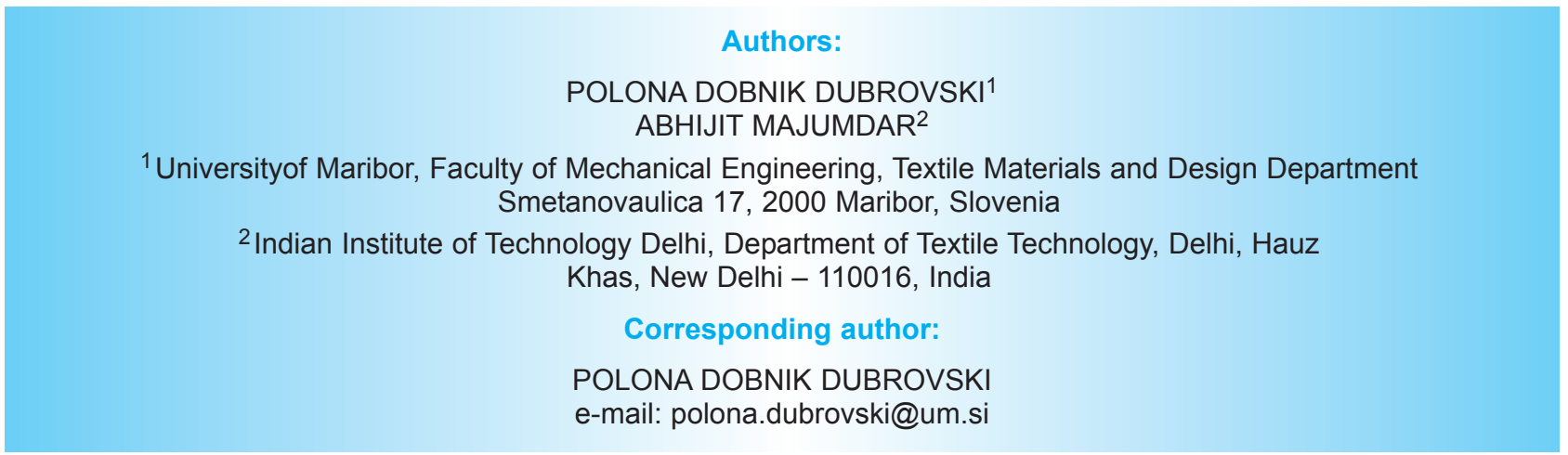




\title{
Polyamide 6/chitosan nanofiber coated HEPA filter for bioaerosol control
}

\author{
DOI: $10.35530 / \mathrm{IT} .068 .06 .1515$
}

\section{REZUMAT - ABSTRACT}

\section{Filtru HEPA acoperit cu nanofibră de poliamidă 6/chitosan pentru controlul bioaerosolului}

Scopul acestui studiu a fost electrofilarea nanofibrelor uniforme cu proprietăți antibacteriene, pentru a le combina cu un material de filtrare a aerului cu particule de înaltă eficiență (HEPA) și pentru a determina performanța acestui filtru compozit. Pentru a atinge aceste obiective, s-au produs nanofibre în amestec poliamidă 6 (PA 6)/chitosan (CS) și a fost analizată activitatea lor antibacteriană. Nanofibrele PA 6/CS au fost acoperite cu un material filtrant comercial HEPA și a fost testată performanța acestui filtru compozit. Analiza activității antibacteriene a arătat că nanofibrele PA 6/CS au avut o activitate antibacteriană foarte bună atât împotriva Staphylococcus aureus, cât și împotriva Escherichia coli. Acoperirea nanofibrei a îmbunătățit eficiența filtrului HEPA. Cu toate acestea, a dus la creșterea căderii de presiune. Eficacitatea filtrului a crescut odată cu scăderea dimensiunii nanofibrei în filtrul HEPA acoperit cu nanofibre. Căderea de presiune nu a urmat aceeași tendință. În primul rând, a scăzut odată cu scăderea diametrului fibrei, dar o scădere suplimentară a diametrului fibrei a determinat o creștere a căderii de presiune. În concluzie, dimensiunea nanofibrelor are un efect important asupra căderii de presiune și pentru a obține o eficiență ridicată a filtrului fără o creștere substanțială a căderii de presiune, este esențial să se realizeze o selecție atentă a dimensiunii nanofibrelor.

Cuvinte-cheie: poliamidă 6, chitosan, electrofilare, nanofibre, filtrarea aerului, activitate antibacteriană

\section{Polyamide 6/chitosan nanofiber coated HEPA filter for bioaerosol control}

The aim of this study was to electrospun uniform nanofibers with antibacterial properties, to combine them with a highefficiency particulate air (HEPA) filter material and to determine the filter performance of this composite filter. To achieve these objectives, polyamide 6 (PA 6)/chitosan (CS) blend nanofibers were produced and their antibacterial activity was analyzed. Then PA 6/CS nanofibers were coated on a commercial HEPA filter material and the filter performance of this composite filter was tested. Antibacterial activity analysis indicated that PA 6/CS nanofibers had very good antibacterial activity against both Staphylococcus aureus and Escherichia coli. Nanofiber coating improved the filter efficiency of the HEPA filter. However, it also increased pressure drop. The filter efficiency increased with decreasing nanofiber size in nanofiber coated HEPA filter. Pressure drop did not follow the same trend. First, it decreased with decreasing fiber diameter, but a further decrease in fiber diameter caused an increase in pressure drop. In conclusion, nanofiber size has a great effect on pressure drop and to get high filter efficiency without a substantial increase in pressure drop a careful selection of nanofiber size is essential.

Keywords: Polyamide 6, chitosan, electrospinning, nanofibers, air filtration, antibacterial activity

\section{INTRODUCTION}

The modern life has changed the lifestyle of the society. Now, people spend more time indoors. As a result, indoor air quality became a vital topic for many researchers [1, 2]. One of the main threats in indoors is bioaerosols. Bioaerosols are particles of biological origin such as bacteria, viruses, fungi, microbial toxins, pollens, and fibers suspended in the air. They can cause several diseases and infections, allergies, and toxic reactions [3]. Bioaerosal are a big threat especially in large and crowded buildings such as nurseries, schools, hospitals, movie theatres and public transportation vehicles, particularly airplanes. Filtration technology is one of the most widely used techniques of controlling bioaerosols. However, microorganisms captured by filters can stay alive [4] and can grow and spread easily if they find suitable living environment $[5,6]$. Antibacterial-treated air filters were developed to prevent this problem [7]. Many researchers worked on how to improve the antibacteriality of air filter materials. Yoon et al. studied the antibacterial activity of the silver coated activated carbon fiber (ACF) filters [8]. Park et al. showed that the multi-walled carbon nanotube (MWCNT) deposited glass fiber air filter had high antibacterial ability against E.coli [9]. MiaśkiewiczPeska and Łebkowska coated the filter fabric with silver nitrate and reported that these filters inhibited both the gram-negative and the gram-positive bacteria [10].

In recent years, application of electrospun nanofibers in industrial air filters has gained significant interest. Several studies revealed that filtration efficiency increases with the decreasing fiber diameter, and the ability of nanofibers to capture submicron particles is better than that of larger fibers [11]. Other advantages of electrospun nanofibers in filtration applications are good interconnectivity of the pores and the possibility to add functionality into fibers. For example with the addition of silver nanoparticles into spinning 
solution nanofibers gain antibacterial properties [12]. Antibacteriality could be also obtained through a polymer with antibacterial activity such as chitosan during electrospinning. Chitosan (CS) is a biocompatible, biodegradable, and nontoxic biopolymer with well known antibacterial properties [13]. However, it is not easy to electrospun pure chitosan and mechanical properties of chitosan nanofibers are rather weak. To overcome this obstacle chitosan has been mixed with synthetic polymers such as polyethylene oxide(PEO) [14, 15, 16, 17], polyvinyl alcohol (PVA) [18, 19], polyethylene terephthalate (PET) [20, 21], poly(ethylene glycol) [22], polycaprolactone (PCL) [23], polylactic acid (PLA) [24], and polyamide 6 (PA 6) [25]. Polyamide 6 has very good mechanical and physical properties, and it can be easily electrospun [26]. Nanofibers produced from polyamide 6 and chitosan blends combine the good mechanical properties of polyamide 6 with the antibacterial property of chitosan. Because of that polyamide 6/chitosan blend nanofibers have been produced for tissue engineering [27], wastewater treatment [28, 29] and protein purification [30] applications in previous studies. It seems they are also good candidate for bioaerosol control. However, their potential for air filter applications has not been addressed yet.

In this study, in order to improve the functionality of the high-efficiency particulate air (HEPA) filters nanofibers with antibacterial properties produced from polyamide 6/chitosan blends. These nanofibers were coated on a typical HEPA filter material and the filter performance of this composite filter material was determined.

\section{EXPERIMENTAL WORK}

\section{Materials}

PA 6 (Ultramid® B24 N 03) was purchased from BASF. Low molecular weight chitosan (viscosity $=5$ cps $(5 \mathrm{~g} / \mathrm{l})$, degree of deacetylation $=80.0 \%$ ) was obtained from Wako Pure Chemical Industries, Ltd. Acetic acid (100\%) and formic acid (85\%) used to dissolve PA6 and chitosan polymers were purchased from Sigma Aldrich. All chemicals were of analytical grade and used without further purification. Commercial HEPA filter material (100\% glass microfiber) was purchased from Mikropor Filter Inc.

\section{Methods}

\section{Preparation of polymer solutions}

PA6/chitosan blend solutions were prepared by dissolving polymers in acetic acid/formic acid solvent mixture in the ratio of 2:1 (v/v) respectively. Two different polymer concentrations (10\% and $13 \%(\mathrm{w} / \mathrm{w})$ for PA 6 and $4 \%$ and $6 \%$ for CS) and four different blend ratios $(1: 1,2: 1,7: 3,8: 2$; PA 6 : CS) were used. All spinning solutions were prepared under constant stirring by a magnetic stirrer for 24 hours at room temperature.

industroia tertila

\section{Electrospinning process}

To decide the optimum polymer concentrations and blend ratios preliminary trials were run using a needleless electrospinning device (a bar electrode type electrospinning device) (figure 1) at Technical University of Liberec. A $10 \mathrm{~mm}$ diameter bar electrode was used during electrospinning. The distance between electrode and collector was $10 \mathrm{~cm}$ and applied voltage was $25 \mathrm{kV}$.

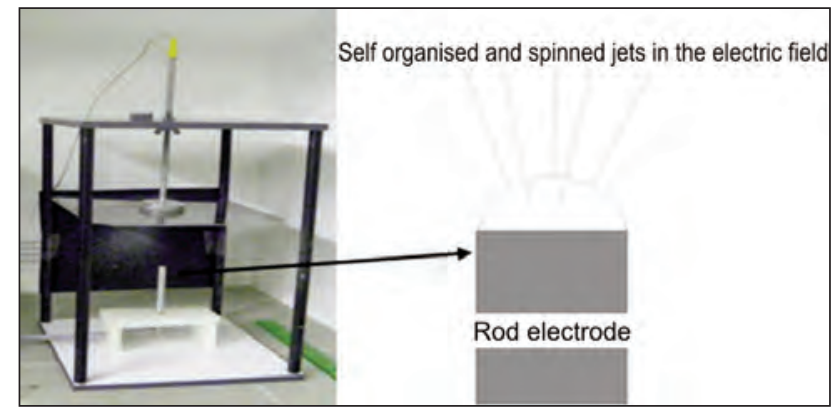

Fig. 1. Needleless electrospinning device

After deciding the optimum polymer concentration and blend ratios further spinning was carried out on a single needle electrospinning device. This device consists of a syringe pump (New Era Syringe Pump System, USA, NE300 model), a high voltage power supply (IsegSpezialelektronik $\mathrm{GmbH}$, Germany) and a metallic collector with dimensions of $20 \mathrm{~cm} \times 20 \mathrm{~cm}$ (figure 2). Polymer solution was fed from a $20 \mathrm{ml}$ glass syringe with a metal needle of $0,8 \mathrm{~mm}$ in diameter (21 Gauge). Solution and spinning parameters used in electrospinning process are given in table 1.

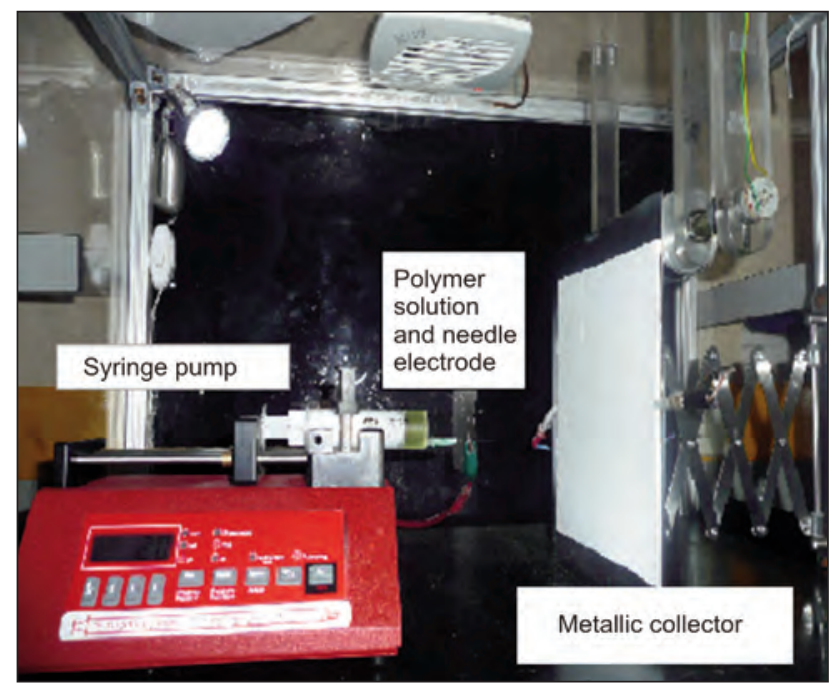

Fig. 2. Single needle electrospinning device

\section{Characterization of morphology}

The morphology of polyamide-6/chitosan nanofibers obtained through needleless electrospinning device was observed by scanning electron microscope SEM TS5130-Tescan and those obtained through a single needle electrospinning device was observed by SEM 
SOLUTION AND SPINNING PARAMETERS USED IN ELECTROSPINNING PROCESS

\begin{tabular}{|c|c|c|c|c|c|c|c|}
\hline \multirow[b]{2}{*}{ Samples } & \multicolumn{3}{|c|}{ Solution parameters } & \multicolumn{4}{|c|}{ Electrospinning parameters } \\
\hline & Concentrations & $\begin{array}{l}\text { Blend Ratios } \\
\text { (w/w) PA6:CS }\end{array}$ & $\begin{array}{c}\text { Conductivity } \\
(\mu \mathrm{s} / \mathrm{cm})\end{array}$ & $\begin{array}{l}\text { Flow rate } \\
(\mu \mathrm{ll} / \mathrm{min})\end{array}$ & \begin{tabular}{|c|} 
Distance \\
between needle \\
tip to collector \\
$(\mathrm{cm})$
\end{tabular} & $\begin{array}{c}\text { Applied } \\
\text { Voltage (kV) }\end{array}$ & $\begin{array}{l}\text { Temperature } \\
\left({ }^{\circ} \mathrm{C}\right) / \text { Relative } \\
\text { Humidity }(\%)\end{array}$ \\
\hline P1 & $13 \%$ PA6/6\%CS & $8: 2$ & 518 & 3 & 7 & 17 & $22 / 50$ \\
\hline P2 & $13 \% \mathrm{PA} 6 / 6 \% \mathrm{CS}$ & $8: 2$ & 518 & 3 & 10 & 17 & $22 / 50$ \\
\hline P3 & $13 \%$ PA6/6\%CS & $8: 2$ & 518 & 3 & 10 & 22 & $22 / 50$ \\
\hline
\end{tabular}

Philips XL-30S FG. Fiber diameters are measured from images via Image J Programme.

\section{Measurement of filter performance}

Filter performance was measured on $\mathrm{NaCl}$ aerosol test equipment (Bench Mounting Rig tipi 1100P) at Technical University of Liberec (figure 3 ). This equipment measures filter efficiency and pressure drop according to the British Standard BS 4400. It is also suitable for testing high efficiency particulate filters (HEPA filters). To test the filter performance HEPA filter samples were cut to a size $15 \times 15 \mathrm{~cm}$ and they were coated with $\mathrm{P} 1, \mathrm{P} 2$ and $\mathrm{P} 3$ nanofibers for 15 minutes. A HEPA filter sample without nanofiber coat was used as negative control. During testing test particles were Sodium Chloride $(\mathrm{NaCl})$, the particle size ranged from $0,002-2 \mu \mathrm{m}$ with the mean particle size of 0,6 $\mu \mathrm{m}$, applied air flow rate was $50 \mathrm{l} / \mathrm{min}$ and air velocity was $5 \mathrm{~m} / \mathrm{min}$.

\section{Analysis of antibacterial activity}

A slightly modified version of AATCC test method 100-2004 was used to determine the antibacterial activity of the PA 6/chitosan nanofibers against methicillin resistant Staphylococcus aureus (ATCC 33592) and Escherichia coli 0157:H7 (RSSK 234, streptomycin-, sulfisoxazole-, and tetracycline-resistant strain). Test bacteria were grown overnight in Mueller Hinton broth (Oxoid). Initial inoculations were prepared by washing cells two times in $0.85 \%$ sterile saline solution. $2 \mathrm{~cm}^{2}$ swatches of each nanofiber were prepared in aseptic conditions and delivered in sterile plastic falcon tubes. Each nanofiber was then saturated with $100 \mu \mathrm{l}$ of suspension of test microorganisms. PA6 nanofibers were used as untreated negative control and PA 6/chitosan nanofibers were used as treated samples. One series of samples were immediately diluted and plated at " 0 " contact time (plated as soon as possible after inoculation) and another series of the samples were incubated at $37^{\circ} \mathrm{C}$ for 3 hours in humid conditions and then plated on appropriate media. $100 \mu \mathrm{l}$ neutralizing solution (Polysorbate $80,30 \mathrm{~g} / \mathrm{l}+$ sodium dodecyl sulphate, $4 \mathrm{~g} / \mathrm{l}+$ lecithin, $3 \mathrm{~g} / \mathrm{l})$ was used in both series to stop the antibacterial activity after the desired contact time

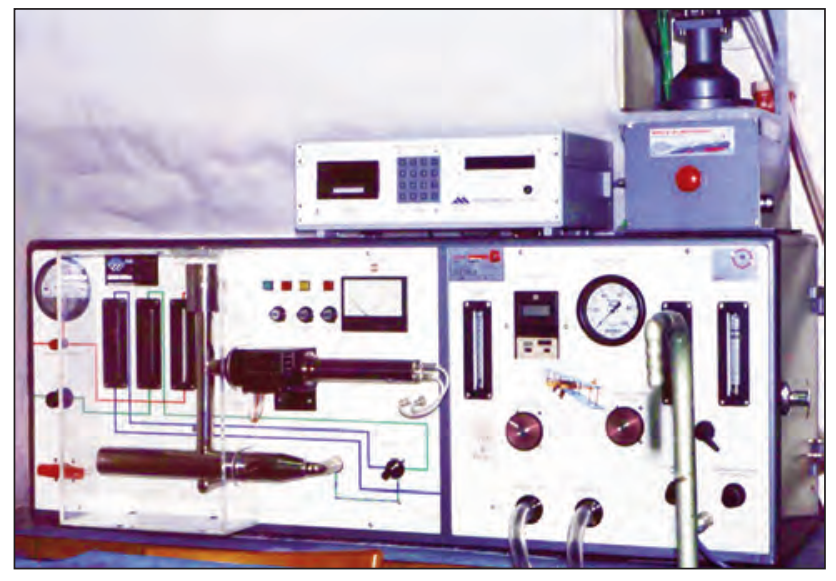

Fig. 3. $\mathrm{NaCl}$ aerosol test equipment (Technical University of Liberec - Filtration Laboratory)

period. After the incubation at $37^{\circ} \mathrm{C}$ for $48 \mathrm{~h}$ colony counts were detected. Results were evaluated as specified in the AATCC 100-2004. All experiments were done in duplicates and mean values were used in evaluation.

The reduction rate in the number of test microorganisms was calculated by using the fallowing formula: $R(\%)=(B-A) B \times 100$. Where $R$ is the percent reduction rate, $A$ is the number of microorganisms recovered from the inoculated nanofibers over the $1 \mathrm{~h}$, and $B$ is the number of microorganisms recovered from the inoculated nanofibers at zero contact time.

\section{RESULTS AND DISCUSSION}

Polymer concentrations and blend ratios are two main factors affecting the spinnability. In the first part of the study in order to decide the optimum concentration of polyamide 6 and chitosan, and the optimum blend ratio of these polymers in the spinning solution electrospinning was carried out on needleless electrospinning device equipped with a bar electrode. Figure 4 shows the SEM image of nanofibers produced from the blend of $10 \%(\mathrm{w} / \mathrm{w})$ PA 6 and $4 \%$ (w/w) chitosan at different weight ratios. As the chitosan ratio increased in the blend the number of beads also increased. When it reached to $50 \%$ almost no fiber were obtained and when it was over 


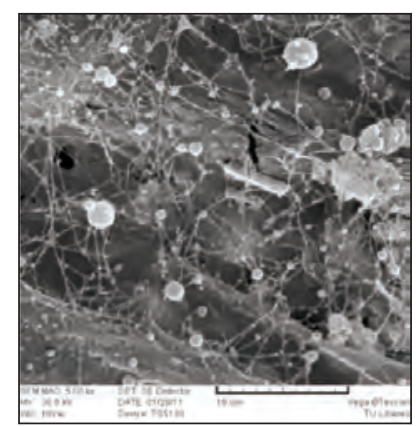

a

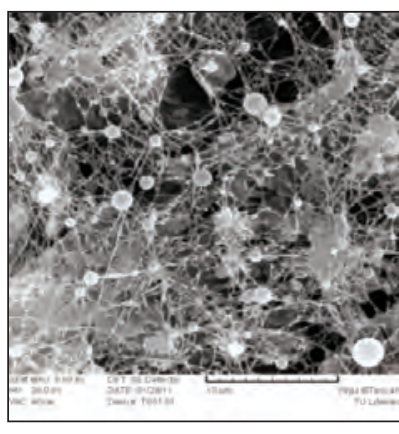

b

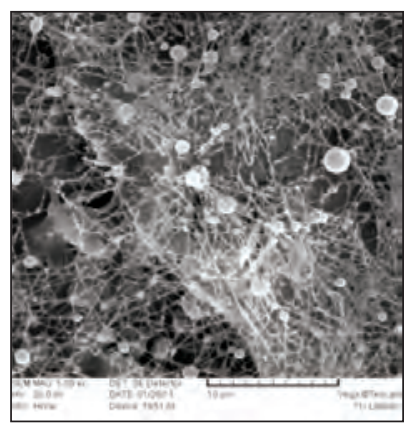

$\boldsymbol{C}$

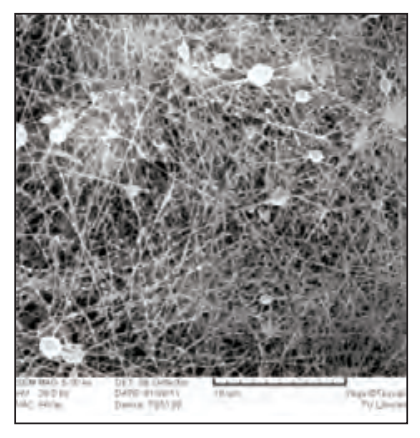

d

Fig. 4. SEM images of nanofibers produced from the blend of $10 \%(w / w)$ PA 6 and $4 \%(w / w)$ chitosan at different weight ratios: $a-1: 1 ; b-2: 1 ; c-7: 3 ; d-8: 2$

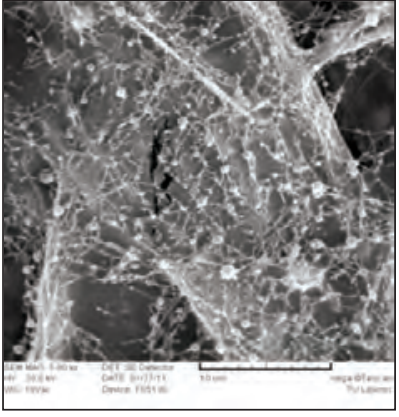

a

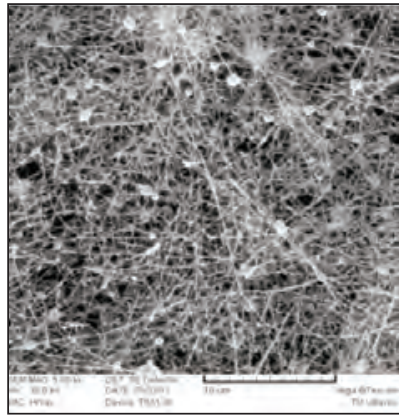

b

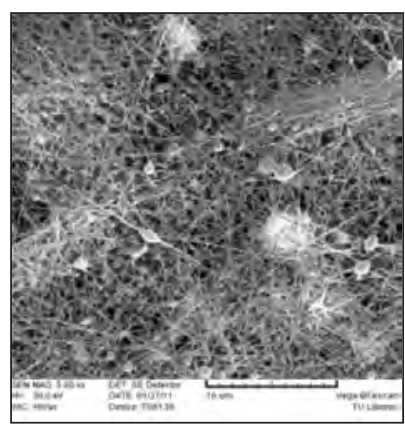

$c$

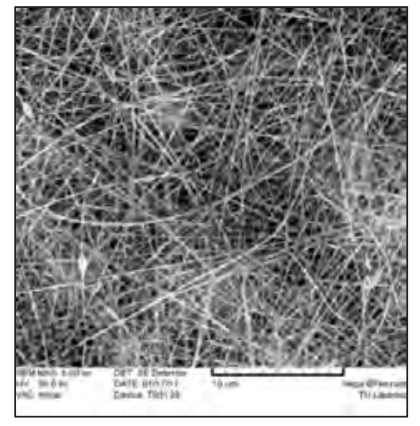

d

Fig. 5. SEM images of nanofibers produced from the blend of $13 \%(w / w)$ PA 6 and $6 \%(w / w)$ chitosan at different weight ratios: $a-1: 1 ; b-2: 1 ; c-7: 3 ; d-8: 2$

$50 \%$ spinning jet was not formed due to high viscosity. Ghani et al. [28] also stated the same problem. In their study increasing of chitosan ratio above $40 \%$ made electrospinning impossible due to high viscosity. A high viscosity makes the ejection of jets from solution difficult and interrupts electrospinning.

Figure 5 shows the SEM image of nanofibers produced from the blend of $13 \%(\mathrm{w} / \mathrm{w})$ PA 6 and $6 \%$ $(w / w)$ chitosan at different weight ratios. The number of beads decreased as the concentrations of PA and chitosan increased. The beadless and homogenous nanofibers were produced from $13 \%$ (w/w) PA 6 and $6 \%(\mathrm{w} / \mathrm{w})$ chitosan at the blend ratio of $8: 2$ (PA6:CS). These spinning solution parameters were accepted as optimum for this study and used in further experiments.

After deciding the optimum polymer concentration and blend ratios to obtain different fiber diameters nanofibers were produced on a single needle electrospinning device at two different needle tip to collector distances and applied voltages given in table 1. We know that fiber size affects pore size and, in turn, filter performance in great extend. Figure $6, a, b, c$ show the SEM images of resultant nanofibers and Figure 6, $d$ shows the HEPA filter material. As seen from the images the average diameters of polyamide 6/chitosan nanofibers were smaller than the average diameter of glass fibers of HEPA filter. When the distance between needle tip to collector and the applied voltage increased, the average fiber diameter decreased. Electrospinning starts when the electrostatic force in the spinning solution overcomes the surface tension of the solution under high voltage. As the applied voltage increases a strong electrical charge causes greater stretch of the spinning solution and leads to finer jets and eventually finer fibers. The distance between needle tip to collector affects jet flight time. An increase in this distance increases flight time causing further stretch of jets, which results in finer fibers [31, 32, 33].

\section{Antibacterial activity nanofibers}

Antibacterial activity of PA and PA6/chitosan nanofibers against $S$. aureus and $E$. coli is given in table 2 . As expected, the PA nanofibers did not possess significant antibacterial activity against either microorganism within the testing period up to $3 \mathrm{~h}$. It seems microorganism species can readily contaminate PA nanofibers, causing serious microorganism buildups. The PA 6/chitosan nanofiber web, on the other hand, demonstrated very good antibacterial activity. It showed 3-log reduction for both microorganisms after 3 hours contact time. Clearly, this is as a result of chitosan content in the blend nanofibers. The antibacterial mechanism of chitosan can be explained as follows. The positively charged chitosan deposits on the negatively charged microbial cell membrane. This alters its permeability and results in leakage of 


\begin{tabular}{|c|c|c|c|c|c|c|c|c|}
\hline \multicolumn{1}{|c|}{ ANTIBACTERIAL ACTIVITY OF PA 6 AND CHITOSAN/PA 6 NANOFIBERS } \\
\hline & $\begin{array}{c}\text { Initial } \\
\text { bacterial } \\
\text { count } \\
\text { (log) }\end{array}$ & $\begin{array}{c}\text { Bacterial } \\
\text { count at "0" } \\
\text { contact time } \\
\text { (log) (B) }\end{array}$ & $\begin{array}{c}\text { Bacterial } \\
\text { count after } \\
\text { 3 h contact } \\
\text { time (log)(A) }\end{array}$ & $\mathbf{R}(\%)$ & $\begin{array}{c}\text { Initial } \\
\text { bacterial } \\
\text { count } \\
\text { (log) }\end{array}$ & $\begin{array}{c}\text { Bacterial } \\
\text { count at “0” } \\
\text { contact time } \\
\text { (log)(B) }\end{array}$ & $\begin{array}{c}\text { Bacterial } \\
\text { count after } \\
\text { 3 h contact } \\
\text { time (log)(A) }\end{array}$ & R (\%) \\
\hline E.coli & $\begin{array}{c}4.310^{6} \\
(6.63)\end{array}$ & $4,1.10^{6}(6,61)$ & $3.8 .10^{6}(6.57)$ & 7.3 & $\begin{array}{c}4.3 .10^{6} \\
(6.63)\end{array}$ & $4.1 .10^{6}(6.61)$ & $3.9 .10^{3}(3.59)$ & 99.9 \\
\hline $\begin{array}{c}\text { S. } \\
\text { aureus }\end{array}$ & $\begin{array}{c}5.1 .10^{6} \\
(6.70)\end{array}$ & $5.0 .10^{6}(6,69)$ & $4.9 .10^{6}(6.69)$ & 2 & $\begin{array}{c}3.8 .10^{6} \\
(6.57)\end{array}$ & $3.4 .10^{6}(6.53)$ & $2.9 .10^{3}(3.46)$ & 99.91 \\
\hline
\end{tabular}

* "R" shows the reduction rate of the bacterial counts. Results are mean values of three different experiments.

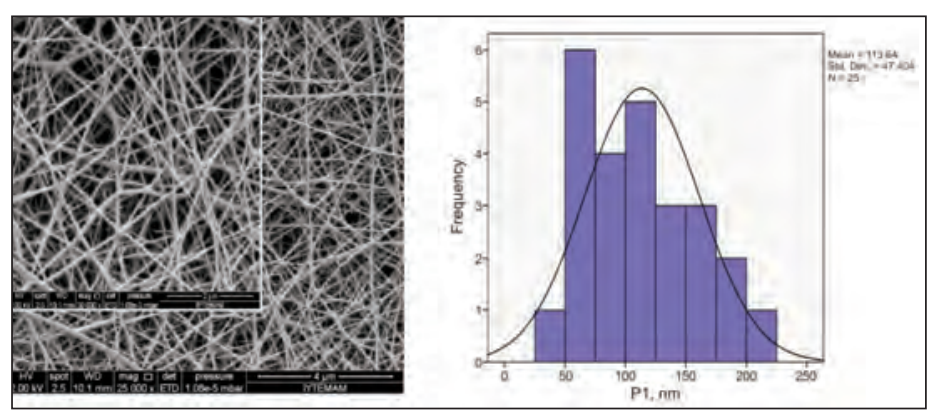

a

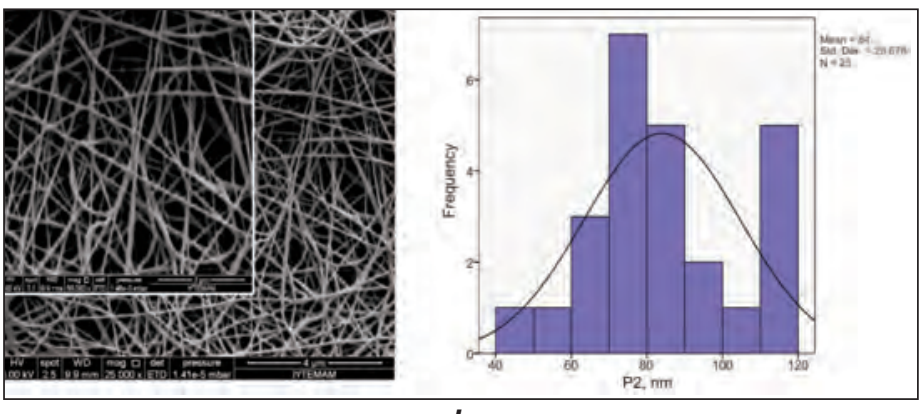

$\boldsymbol{b}$
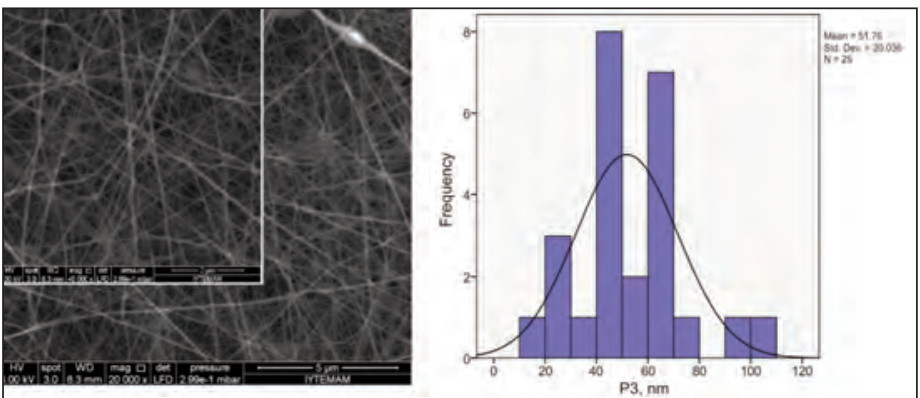

C

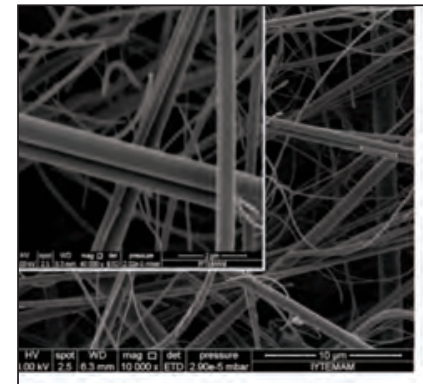

.

Fig. 6. SEM Images and the fiber diameter distribution histograms of $\mathrm{P} 1$ nanofibers $(a), \mathrm{P} 2$ nanofibers $(b), \mathrm{P} 3$ nanofibers $(c)$, and HEPA filter sample $(d)$

industroia textilă intracellular constituents leading death of cell $[13,34,35]$. Even though HEPA filters are $99.97 \%$ efficient at the $0.3 \mu \mathrm{m}$ particle size and be able to capture microscopic particles, such as bacteria and viruses, there is still a need to kill the bacteria and viruses that become trapped in the filter [36]. Because of that HEPA filters are usually combined with high-energy ultraviolet lights in healthcare facilities and nursing homes. Thus, a nanofiber layer with antibacterial activity could be an effective alternative way of destroying these trapped microorganisms.

\section{Filter performance}

Filter efficiency of nanofiber coated HEPA filters were tested on $\mathrm{NaCl}$ Aerosol Test Equipment and compared with uncoated HEPA filter (table 3). Filter efficiencies of nanofiber coated filters were higher than that of HEPA filter. As nanofiber diameter decreased filter efficiency increased as expected. However, for the best filtration results high filter efficiency should accompany with low pressure drop [37]. Pressure drop values of nanofiber coated filters were relatively high compared to uncoated HEPA filter.

It's well known that aerosol particles can be deposited on a fiber in a filter by five basic mechanisms, which are interception, inertial impaction, diffusion, gravitational settling, and electrostatic attraction. One of the advantages of nanofibers for filtration is small pore size and the other one is the slip-flow, which refers to the air flow passing the nanofiber without colliding it. This affects filtration in two ways. First, the pressure drop through the nanofiber medium will be less compare to microfiber medium due to less air drag on the fiber. Second, direct interception of small particles in the air flow will be better since more of them pass close enough to collide with the nanofiber. Unlike conventional filters the slip 


\begin{tabular}{|c|c|c|}
\hline \multicolumn{3}{|c|}{ FILTER PROPERTIES } \\
\hline Filters & $\begin{array}{c}\text { Filter Efficiency } \\
\text { (\%) }\end{array}$ & $\begin{array}{c}\text { Pressure Drop } \\
\text { (Pa) }\end{array}$ \\
\hline $\begin{array}{c}\text { F1: HEPA coated } \\
\text { with P1 }\end{array}$ & 99,999946 & 3800 \\
\hline $\begin{array}{c}\text { F2: HEPA coated } \\
\text { with P2 }\end{array}$ & 99,999970 & 1446 \\
\hline $\begin{array}{c}\text { F3: HEPA coated } \\
\text { with P3 }\end{array}$ & 99,999973 & 2040 \\
\hline $\begin{array}{c}\text { UF: Uncoated } \\
\text { HEPA filter }\end{array}$ & 99,999890 & 482 \\
\hline
\end{tabular}

The smooth and bead-free polyamide 6/chitosan nanofibers were obtained from $13 \%(\mathrm{w} / \mathrm{w})$ PA 6 and $6 \%(\mathrm{w} / \mathrm{w})$ chitosan at the blend ratio of 8:2 (PA 6/CS $(w / w))$. Subsequently, polyamide $6 /$ chitosan nanofibers were produced by a single syringe electrospinning device using two different needle tip to collector distances and applied voltages to attain various fiber diameters. The average fiber diameters of resulting nanofibers were 113,84 and $51 \mathrm{~nm}$. Increasing tip to collector distance and applied voltage decreased fiber diameter.

The antibacterial activity of polyamide 6/chitosan nanofibers was analyzed according to AATCC test method 100-2004. Polyamide 6/chitosan nanofibers showed very high antibacterial activity against Staphylococcus aureus and Escherichia coli. This suggests that with the incorporation of polyamide 6/chitosan nanofibers a regular filter material would gain antibacterial properties.

To determine the effect of Polyamide 6/chitosan nanofibers on filter performance ofa HEPA filter they were spun on a commercial HEPA filter material. Filter performance of this composite filter material was tested by $\mathrm{NaCl}$ aerosol test equipment. HEPA filters already have very high filter efficiency, but nanofiber coating further improved the filter efficiency. As the nanofiber diameter decreased the filter efficiency increased. However, nanofiber coating also increased pressure drop. The amount of increase depended on fiber size. Pressure drop first decreased with decreasing fiber diameter, then it increased with further decrease in diameter in the nanofiber coated HEPA filter. As a result, it is concluded that the effect of nanofiber diameter on pressure drop is as important as pore size in filter materials. In order to get high filter efficiency without a substantial increase in pressure drop a careful selection of nanofiber size is essential.

\section{ACKNOWLEDGEMENT}

The authors would like to thank Prof. Dr. David Lukáš, Assoc. Prof. Lenka Martinová and their research group and Ing. Ph.D. Jakub Hrůza for their assistance throughout this work. In addition, we wish to thank Dr. FigenOzyildiz for her help in antibacterial activity tests.

\section{BIBLIOGRAPHY}

[1] Jones, A.P. Indoor air quality and health, In: Atmos Environ, 1999, vol. 33, issue 28, pp. 4535-4564.

[2] Daisey, J.M., Angell, W.J. Apte MG. Indoor air quality, ventilation and health symptoms in schools: an analysis of existing information, In: Indoor Air, 2003, vol. 13, issue 1, pp. 53-64.

[3] Burge, H. Bioaerosols: prevalence and health effects in the indoor environment, In: J Allergy Clinlmmunol, 1990, vol. 86 , issue 5 , pp. 687-701.

[4] Wang, Z., Reponen, T., Willeke, K. and Grinshpun, S.A. Survival of Bacteria on respirator filters, In: Aerosol Sci. Technol., 1999, vol. 30, issue 3, pp. 300-308.

[5] Kemp, P.C., Neumeister-Kemp, H.G., Lysek, G. and Murray, F. Survival and growth of micro-organisms on air filtration media during initial loading, In: Atmos. Environ., 2001, vol. 35, issue 28, pp. 4739-4749. 
[6] Maus, R., Goppelsroder, A. and Umhauer, H. Survival of bacterial and mold spores in air filter media, In: Atmos. Environ. 2001, vol. 35, issue 1, pp. 105-113.

[7] Foarde, K.K. and Hanley, J.T. Determine the efficacy of antimicrobial treatments of fibrous air filters, In: ASHRAE Trans., 1999, 4429(RP-909).

[8] Yoon, K.Y., Byeon, J.H., Park, C.W. and Hwang, J. Antimicrobial effect of silver particles on bacterial contamination of activated carbon fibers, In: Environ. Sci. Technol., 2008, vol. 42, issue 4, pp. 1251-1255.

[9] Park, J.H., Yoon, K.Y., Na, H., Kim, Y.S., Hwang, J., Kim, J. and Yoon, Y.H. Fabrication of a multiwalled carbon nanotube-deposited glass fiber air filter for the enhancement of nano and submicron aerosol particle filtration and additional antibacterial efficacy, In: Sci. Total Environ., 2011, vol. 409, issue 19, pp. 4132-4138.

[10] Miaśkiewicz-Peska, E. and Łebkowska, M., Effect of antimicrobial air filter treatment on bacterial survival, In: Fibres Text. East. Eur., 2011, vol. 19, issue1, pp. 73-77.

[11] Qin, X.H., Wang S.Y. Filtration properties of electrospinning nanofibres, In: J. Appl. Polym. Sci., 2006, vol. 102, issue 2, pp. 1285-1290.

[12] Lala, N.L., Ramaseshan, R., Bojun, L., Sundarrajan, S., Barhate, R.S., Ying-jun, L., Ramakrishna, S. Fabrication of nanofibers with antimicrobial functionality used as filters - protection against bacterial contaminants, In: Biotechnology and Bioengineering, 2007, vol. 97, issue 6, pp. 1357-1365.

[13] Kong, M., Chen, X.G., Xing, K., Park, H.J. Antimicrobial properties of chitosan and mode of action: a state of the art review, In: International Journal of Food Microbiology, 2010, vol. 144, issue 1, pp. 51-63.

[14] Kriegel, C., Kit, K.M., McClements, D.J., Weiss, J. Electrospinning of chitosan-poly(ethylene oxide) blend nanofibers in the presence of micellar surfactant solutions, In: Polymer, 2009, vol. 50, issue 1, pp. 189-200.

[15] Kriegel, C., Kit, K.M., McClements, D.J., Weiss, J. Influence of surfactant type and concentration on electrospinning of chitosan-poly(ethylene oxide) blend nanofibers, In: Food Biophysics, 2009, vol. 4, issue 3, pp. 213-228.

[16] Zhang, J.F., Yang, D.Z., Xu, F., Yin, R.X., Nie, J. Electrospuncore!shell structure nanofibers from homogeneous solution of poly(ethylene oxide)/chitosan, In: Macromolecules, 2009, vol. 42, issue 14, pp. 5278-5284.

[17] Dogan, G., Ozyildiz, F., Basal, G., Uzel, A. Fabrication of electrospun chitosan and chitosan/poly(ethylene oxide) nanofiber webs and assessment of their antimicrobial activity, In: International Polymer Processing, 2013, vol. 28, issue 2, pp. 143-150.

[18] Zheng, H., Du, Y., Yu, J., Huang, R., Zhang, L. Preparation and characterization of chitosan/poly(vinyl alcohol) blend fibers, In: Journal of Applied Polymer Science, 2001, vol. 80, issue 13, pp. 2558-2565.

[19] Zhang, Y., Huang, X., Duan, B., Wu, B., Li, S., Juan, X. Preparation of electrospun chitosan/poly(vinyl alcohol) membranes, In: Colloid and Polymer Science, 2007, vol. 285, issue 8, pp. 855-863.

[20] Jung, K.H., Huh, M.W., Meng, W., Yuan, J., Hyun, S.H., Bae, J.S., Hudson, S.M., Kang, I.K. Preparation and antibacterial activity of PET/chitosan nanofibrous mats using an electrospinning technique, In: Journal of Applied Polymer Science, 2007, vol. 105, issue 5, pp. 2816-2823.

[21] Lopes-da-Silva, J.A., Veleirinho, B., Delgadillo, I. Preparation and characterization of electrospun mats made of PET/chitosan hybrid nanofibers, In: Journal of Nanoscience and Nanotechnology, 2009, vol. 9, issue 6, pp. 3798-3804.

[22] Kolhe, P., Kannan, R.M. Improvement in ductility of chitosan through blending and copolymerization with PEG: FTIR Investigation of Molecular Interactions, In: Biomacromolecules, 2003, vol. 4 , issue 1, pp. 173-180.

[23] Shalumon, K.T., Anulekha, K.H., Girish, C.M., Prasantha, R., Naira, S.V., Jayakumar, R. Single step electrospinning of chitosan/poly(caprolactone) nanofibers using formic acid/acetone solvent mixture, In: Carbohydrate Polymers, 2010, vol. 80, issue 2, pp. 413-419.

[24] Xu, J., Zhang, J. H., Gao, W. Q., Liang, H., Wang, H., Li J. Preparation of chitosan/PLA blend micro/nano-fibers by electrospinning, In: Materials Letters, 2009, vol. 63, issue 8, pp. 658-660.

[25] Zhang, H. T., Li, S. B., Christopher, J., Ning, X., Nie, H., Zhu, L. Studies on electrospun nylon-6/chitosan complex nanofiber interactions, In: ElectrochimicaActa, 2009, vol. 54, issue 24, pp. 5739-5745.

[26] Stephens, J.S., Chase, D.B. and Rabolt, J.F. Effect of the electrospinning process on polymer crystallization chain conformation in nylon-6 and nylon-12, In: Macromolecules, 2004, vol. 37, issue 3, pp. 877-881.

[27] Nirmala, R., Navamathavan, R., Kang, H.S., El-Newehy, M. H. and Kim, H. Y. Preparation of polyamide-6/chitosan composite nanofibers by a single solvent system via electrospinning for biomedical applications, In: Colloids and Surfaces B, 2011, vol. 83, issue 1, pp. 173-178.

[28] Ghani, M., Gharehaghaji, A.A., Arami, M., Takhtkuse, N., andRezaei, B. Fabrication of electrospun polyamide6/chitosan nanofibrous membrane toward anionic dyes removal, In: Journal of Nanotechnology, 2014, vol. 2014, Article ID 278418, 12 pages.

[29] Maryšková, M., Ardao, I, García-González, C.A., Martinová, L., Rotková, J., Ševců, A. Polyamide 6/chitosan nanofibers as support for the immobilization of Trametes versicolor laccase for the elimination of endocrine disrupting chemicals, In: Enzyme Microb Technol., 2016 , vol. 89, pp. 31-38.

[30] Zhang, H., Wu, C., Zhang Y., White C., J.B. , Xue, Y, Nie H, Zhu, L. Elaboration, characterization and study of a novel affinity membrane made from electrospun hybrid chitosan/nylon-6 nanofibers for papain purification, In: Journal of Materials Science, 2010, vol. 45, issue 9, pp. 2296-2304.

[31] Homayonia , H., Ravandi, S. A. H., Valizadeh, M. Electrospinning of chitosan nanofibers: Processing optimization, In: Carbohydrate Polymers, 2009, vol. 77, issue 3, pp. 656-661. 
[32] Frenot, A., Chronakis, I. Polymer nanofibers assembled by electrospinning, In: Current Opinion in Colloid and Interface Science, 2003, vol. 8, issue 1, pp. 64-75.

[33] Ramakrishna, S., Fujihara, K., Teo, W.E., Lim, T.C., Ma, Z. Introduction to electrospinning and nanofibers, In: Word Scientific Publishing, Singapore, 2005, pp. 90-152.

[34] Papineau, A.M., Hoover, D.G., Dnorr, D., Farkas, D.F. Antimicrobial effect of water-soluble chitosans with high hydrostatic pressure, In: Food Biotechnology, 1991, vol. 5, issue 1, pp. 45-57.

[35] Helander, I.M., Nurmiaho-Lassila, E.L., Ahvenainen, R., Rhoades, J., Roller, S. Chitosan disrupts the barrier properties of the outer membrane of gram-negative bacteria, In: International Journal of Food Microbiology, 2001, vol. 71, issue 2-3, pp. 235-244.

[36] Himanshu Mittal, S.R.P., Pottage, T., Walker, J.T., \& Bennett, A.M. Survival of microorganisms on HEPA filters, In: Applied Biosafety, 2011, vol. 16, pp. 163-166.

[37] Matteson, M.J., Orr, C. Filtration: Principles and practices, In: Marcel Dekker, New York, 1987, pp. 1-8.

[38] Graham, K., Ouyang, M., Raether, T., Grafe, T., McDonald, B., Knauf, P. Polymeric nanofibers in air filtration applications, In: The Fifteenth Annual Technical Conference \& Expo of the American Filtration \& Separations Society, Galveston, Texas, April 9-12, 2002.

[39] Sundarrajana, S., Tana, K.L., Lima, S. H., Ramakrishnab, S. Electrospun nanofibers for air filtration applications, In: Procedia Engineering, 2014, vol. 75, pp. 159-163.

\section{Authors:}

MSc. Eng. Deniz Ozden ${ }^{1}$

Assoc. Prof. Dr. Guldemet Basal ${ }^{2}$

${ }^{1}$ Ege University, Faculty of Engineering, Department of Textile Engineering 35100, Bornova-Izmir, Turkey

${ }^{2}$ Ege University, Faculty of Engineering, Department of Textile Engineering 35100, Bornova-Izmir, Turkey

Corresponding author:

Assoc. Prof. Dr. Guldemet Basal

e-mail: guldemet.basal@ege.edu.tr

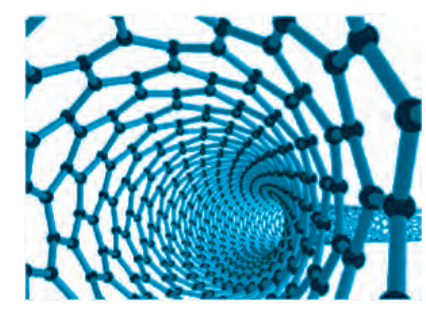




\section{Effect of roving linear density on the quality parameters of $16 \mathrm{Nec}$ $100 \%$ cotton yarn}

ABDUL WAQAR RAJPUT

DOI: $10.35530 / \mathrm{IT} .068 .06 .1576$

RANA AMJAD

USMAN ALI

SIDRA SALEEMI

AMIR ABBAS

\section{REZUMAT - ABSTRACT}

Efectul densității lineare a semitortului asupra parametrilor de calitate ai firelor de bumbac 16 Nec

În acest studiu a fost prezentat efectul densității lineare a semitortului asupra firului de bumbac 16 Nec. Semitortul sub formă de sculuri joacă un rol important în procesul de filare cu inele. Semitorturile mai grele duc la o producție mai mare, însă un semitort mai greu presupune o laminare mai mare pe mașina de filat cu inele, care ar putea avea ca rezultat deteriorarea calității firelor. Pe de altă parte, un semitort mai ușor reduce producția și, prin urmare, duce la creșterea costului de producție. În acest studiu au fost prelucrate semitorturi cu diferite densități liniare în fire de $16 \mathrm{Nec}$. Au fost testate și analizate indicele de uniformitate, indicele IPI și proprietățile de rezistență la întindere. S-au obținut cinci semitorturi cu densitate liniară de 0,82 Nec, 0,87 Nec, 0,92 Nec, 0,97 Nec și 1,02 Nec prin menținerea tuturor parametrilor la aceleași valori. Fire $16 \mathrm{Nec}$ au fost produse prin utilizarea acestor semitorturi, iar parametrii de calitate au fost testați și analizați. Studiul a arătat că reducerea densității semitortului influențează pozitiv U\% și IPI, însă, cu toate acestea nu au existat efecte semnificative de scădere a densității semitortului asupra proprietăților de rezistență la tracțiune a firelor.

Cuvinte-cheie: semitort sub formă de sculuri, fire $16 \mathrm{Nec}$, calitatea firului, IPI, laminare

\section{Effect of roving linear density on the quality parameters of $16 \mathrm{Nec} 100 \%$ cotton yarn}

In this study the effect of roving linear density on the $16 \mathrm{Nec}$ cotton yarn was studied. Hank roving plays an important role in ring spinning process. Heavier roving results in higher production however heavier roving mean higher draft on the subsequent ring spinning frame which could cause deterioration in the yarn quality. On the other hand lighter roving reduces the production hence increases the process cost. In this study roving with different linear densities were processed into the $16 \mathrm{Nec}$ yarn. The uniformity index, IPI index and tensile properties were tested and analysed. Five rovings with linear density of $0.82 \mathrm{Nec}, 0.87 \mathrm{Nec}, 0.92 \mathrm{Nec}, 0.97 \mathrm{Nec}$ and $1.02 \mathrm{Nec}$ were produced by keeping all the parameters same. $16 \mathrm{Nec}$ yarns were produced by utilising these rovings the quality parameters were tested and analysed. The study showed that the reduction in the roving density positively influences the $U \%$ and IPI however there were no significant effects of decrease in roving density on yarn tensile properties.

Keywords: hank roving, $16 \mathrm{Nec}$, yarn quality, IPI, draft

\section{INTRODUCTION}

Yarn manufacturing is becoming very competitive day by day. The raw material cost about $50 \%$ to $70 \%$ of the manufacturing cost, since the cotton price is out of the control of the manufacturer tries to reduce the manufacturing cost $[1,2]$. The emphasis is being on the quality at cheaper manufacturing cost. Cotton yarn manufacturing is multistage process. One of such stage is roving. Manufacturer try to use the heavier roving which results in higher production. However the heavier roving compel the manufacturer to apply higher draft on the ring frame, which could result in the deterioration in the yarn quality [3]. There are no clear guidelines which indicate the right linear density of roving for certain yarn count. In this study it was intended to investigate the effect of roving liner density on the quality parameters of yarns. The general guideline provided by Kumar et al. indicates the major factors that influence the irregularity of fibrous material during drafting on roving frame including; irregularity in the feed material, unsatisfactory condition of the drafting elements, faults in design and uneven fibre distribution of different lengths in cross section [4, 5]. The irregular movement of fibres increases with the draft also due to the difference in the fibre length in the product cross section, this irregular movement occurs at any draft although their magnitude increases with the increase in draft [6]. However; at roving frame the irregularity added is relatively low and almost independent of draft [5]. Balasubramanian determined the effect of roving density on the relative variance of different yarn count [5]. The investigation was not focused on finding the optimised values for producing a certain count. Three different drafts for 1 hank roving and 2 drafts for 1.5 hank rovings for one type of cotton were investigated while using different varieties of cotton to produce yarn from 2, 4 and 6 Hank rovings [5]. It was concluded that $2 \mathrm{Nec}$ hank roving is superior for producing superior quality yarn in terms of relative variations, however; the effect of roving density on IPI 
were not discussed along with other quality parameters. Since there were many factors involved, an optimised roving for any given yarn count has not been determined. In this study, an effort has been made to determine the optimum values of hank roving for the production of $16 \mathrm{Nec}$ cotton count. Hank rovings of different linear densities were prepared using the same processing parameters. 16 Nec 100\% cotton yarn was prepared using the roving of different linear densities.

\section{EXPERIMENTAL WORK}

\section{Materials and method}

In this study $100 \%$ cotton fibers, table 1, was used as raw material. Rieter blow room consisting of mixing bale opener, Uniclean B11, Mixing opener MO, Uniflex B60 were used for opening and cleaning of cotton fibres. Fibres were then processed on Card C51 to produce sliver of 56 grains/yard. The carded slivers were doubled twice on draw frame to achieve homogeneous sliver. The drawing was carried out on Rieter RSB D35, 6 sliver were doubled to form a single sliver of 63 grains/yard. Slivers were again passed through the draw frame to achieve better homogeneity 6 slivers of 63 grains/yard were doubled to form 63 grains/yard sliver. The drawn slivers were then processed on Simplex FA 415A to from the rovings of $0.82 \mathrm{Nec}, 0.87 \mathrm{Nec}, 0.92 \mathrm{Nec}, 0.97 \mathrm{Nec}$ and $1.02 \mathrm{Nec}$. The twist factor (TM) of all the rovings was kept same i.e. 1.25. $16 \mathrm{Nec}$. Yarn samples were produced from $0.82 \mathrm{Nec}, 0.87 \mathrm{Nec}, 0.92 \mathrm{Nec}, 0.97$ $\mathrm{Nec}$ and $1.02 \mathrm{Nec}$ rovings on ring frame EJM 168, the adjustments of the machine are shown in table 2. Yarn samples were conditioned at $20 \pm 2^{\circ} \mathrm{C}$ and $65 \pm$ $5 \%$ relative humidity for 24 hours before testing according to ISO standard. The samples were then tested on Uster Evenness Tester 4 equipped with capacitive sensor and optical sensors to determine the mass variation, evenness and imperfection at the speed of $400 \mathrm{~m} / \mathrm{min}$ as per ISO 16549:2004 test metho, each result shows an average of 10 results taken from 10 different packages. Uster Tensorepid4 was used to measure single yarn strength and elongation, 20 measurements were taken from each bobbin (total 10 bobbins).
Table 1

\begin{tabular}{|l|c|}
\hline $50 \%$ span length (inch) & 0.5432 \\
\hline $2.5 \%$ span length (inch) & 1.0956 \\
\hline Floating fibre \%age & 17.05 \\
\hline Fibre Fineness & 5.10 \\
\hline Fibre strength (Pressley value) & 85 \\
\hline
\end{tabular}

Table 2

\begin{tabular}{|l|c|c|c|c|c|}
\hline $\begin{array}{l}\text { Hank } \\
\text { roving }\end{array}$ & $0.82 \mathrm{Nec}$ & $0.87 \mathrm{Nec}$ & $0.92 \mathrm{Nec}$ & $0.97 \mathrm{Nec}$ & $1.02 \mathrm{Nec}$ \\
\hline $\begin{array}{l}\text { Break } \\
\text { Draft }\end{array}$ & 1.38 & 1.38 & 1.38 & 1.38 & 1.38 \\
\hline $\begin{array}{l}\text { Total } \\
\text { Draft }\end{array}$ & 20.5 & 19.34 & 18.49 & 17.46 & 16.8 \\
\hline TM & 4.2 & 4.2 & 4.2 & 4.2 & 4.2 \\
\hline TPI & 16.8 & 16.8 & 16.8 & 16.8 & 16.8 \\
\hline
\end{tabular}

\section{RESULTS AND DISCUSSION}

The results of $16 \mathrm{Nec}$ yarns $U \%$, thick places, thin places, neps, tenacity and B-work spun with 0.82 , $0.87,0.92,0.97$ and 1.02 rovings are given in table 3 .

\section{Comparison of yarn evenness}

Yarn evenness is very important yarn quality parameter. It represents the variation in weight per unit length of yarn. Uster tester 4 uses the capacitive sensors to measure unevenness in the yarn passed between two conductors separated by an air gap the yarn acts as dielectric hence any difference in the mass variation reflects on the conductive plates [7]. The irregularity in the yarn mass is represented by percent variation from the mean value of the sample tested. The irregularity (U\%) (figure 1) of the tested samples showed direct relation with the decrease in the roving density. Samples produced from 0.97 hank roving showed $20 \%$ improvement compared to samples produced from $0.82 \mathrm{HR}$. However further decrease in the roving density increased the irregularity. This increase in the irregularity could be the result of lower draft present, the presence of lesser number of fibres in the feed leads to the lesser interfibre

Table 3

\begin{tabular}{|l|c|c|c|c|c|}
\hline \multicolumn{7}{|c|}{ YARN QUALITY PARAMETERS AGAINST ROVING LINEAR DENSITY } \\
\hline & $\mathbf{0 . 8 2} \mathbf{~ N e c}$ & $\mathbf{0 . 8 7} \mathbf{~ N e c}$ & $\mathbf{0 . 9 2} \mathbf{~ N e c}$ & $\mathbf{0 . 9 7}$ Nec & $\mathbf{1 . 0 2}$ Nec \\
\hline U\% & 13.19 & 12.5 & 11.45 & 10.46 & 12.04 \\
\hline Thin $\mathbf{5 0 \%}$ & 9 & 9 & 7 & 5 & 6 \\
\hline Thick +50\% & 129 & 125 & 123.3 & 111 & 90 \\
\hline Nep +200\% & 6.8 & 6.8 & 4.5 & 4.3 & 6.5 \\
\hline IPI & 144.8 & 140.8 & 134.8 & 120.3 & 112.5 \\
\hline B-Force & 654.8 & 685.7 & 668.2 & 666.4 & 652.3 \\
\hline Tenacity CN/Tex & 17.74 & 18.58 & 18.1 & 18.06 & 17.67 \\
\hline B-Work & 862.0 & 904.3 & 863.2 & 887.2 & 857.7 \\
\hline
\end{tabular}




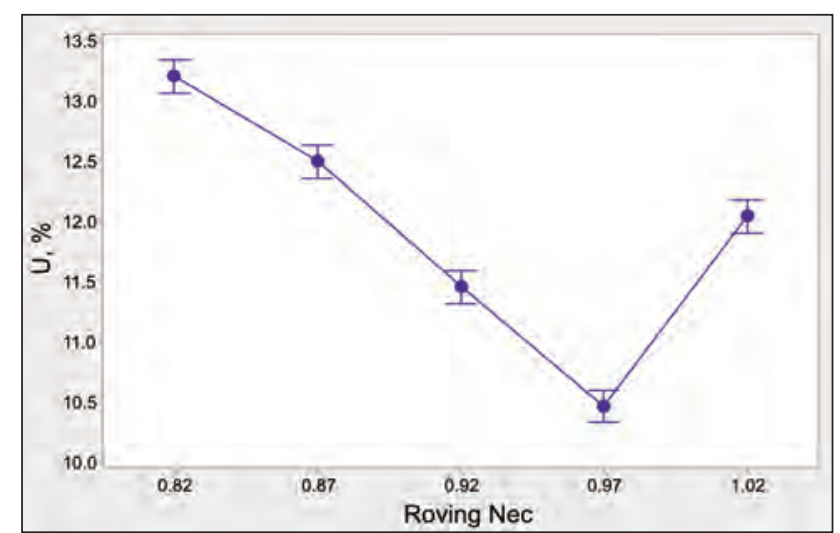

Fig. 1. Comparison of $U \%$

friction which results in lack of straightening and aligning of fibres entering the drafting zone [8-11].

\section{Comparison of IPI}

IPI is the imperfection index it represents the tick places, thin places and neps. Occurrences of yarn mass $50 \%$ more than the yarn mean value per kilometre represents thick places, similarly occurrences of $50 \%$ thinner places in yarn are called thin places. Small knot like entangled fibres having mass $200 \%$ to the yarn mean mass per kilometre is called nep [10]. Thin places $(-50 \%)$ decreased with the decreased in the roving linear density however at $1.02 \mathrm{Nec}$ the number of thick places slightly increased. Similarly thick places $(+50 \%)$ improved in direct relation with reduction in roving linear density. Occurrence of thin places improved by $30 \%$ indicating significant direct relation between thin places and reduction in roving linear density. Nep $(+200 \%)$ also improved with the decrease in the linear density till $0.97 \mathrm{Nec}$ further reduction in the linear density increased nep count [12]. However the overall IPI improved with the decrease in the roving linear density. Samples corresponding with $1.02 \mathrm{Nec}$ roving improved IPI by $21.7 \%$ indicating significant effect of roving linear density on the sample IPI (figure 2).

\section{Comparision of tensile properties}

Breaking force (B-force) is the measure of the tensile force required to break a sample and is given by

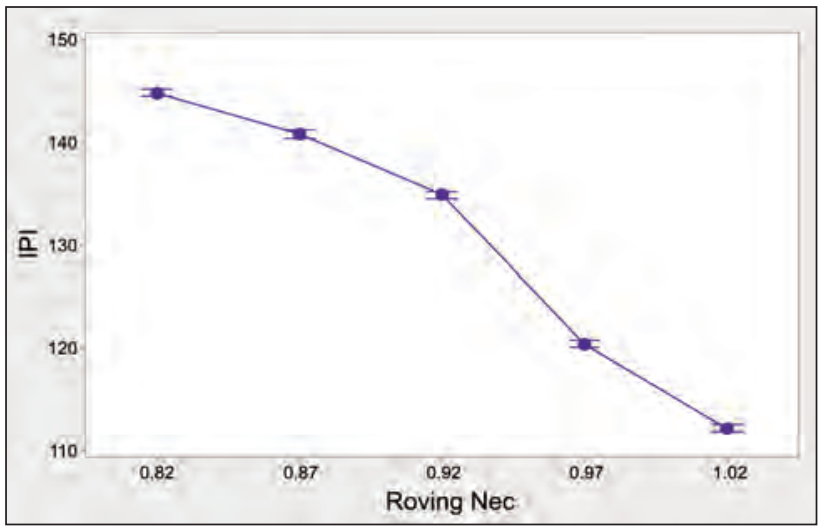

Fig. 2. Comparison of IPI maximum force developed during a tensile test [13-15]. 5\% improvement in the B-force was shown by the sample produced from $0.87 \mathrm{Nec}$ roving comapred to the $1.02 \mathrm{Nec}$ roving (figure 3). Tenacity is explained as the force per unit linear density. it is also explained in term of rupture per kilometer (RKM). RKM is defined as the length of specimen at which it will break the yarn under its own weight $[13,16]$. The tenaicty of the $0.87 \mathrm{Nec}$ also has $5 \%$ higher values than $1.02 \mathrm{Nec}$ specimen figure 4. B-Work is work of break also called work of rupture it represent the toughnes of the yarn it is the modulus of the yarn which is measured by the area under the curve of the stress strain graph [17]. $0.87 \mathrm{Nec}$ samples showed

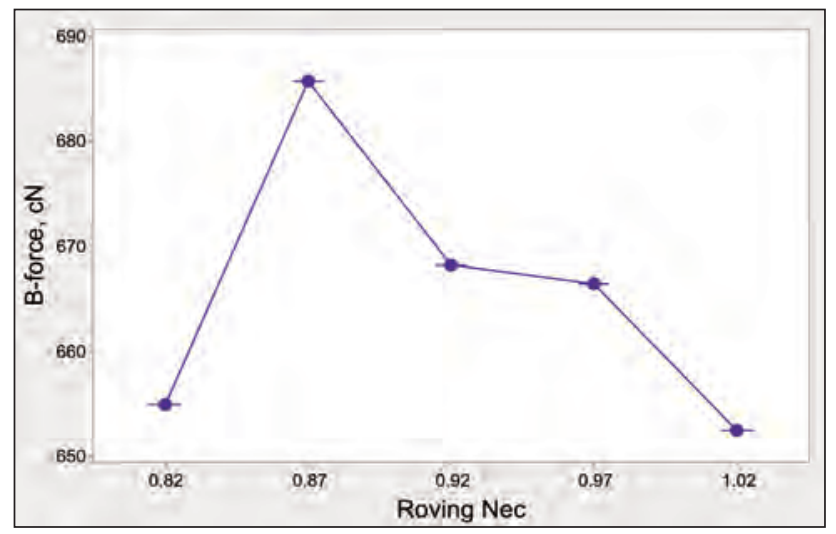

Fig. 3. Comparison of B-force

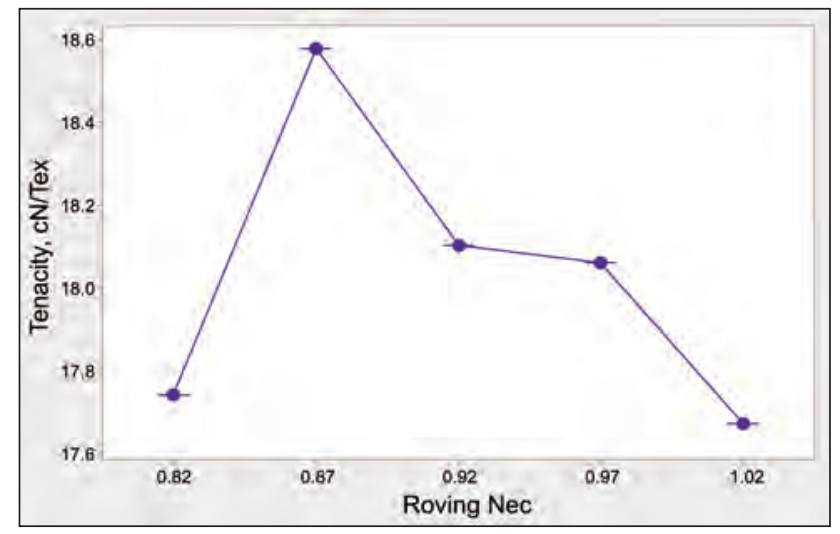

Fig. 4. Comparison of tenacity

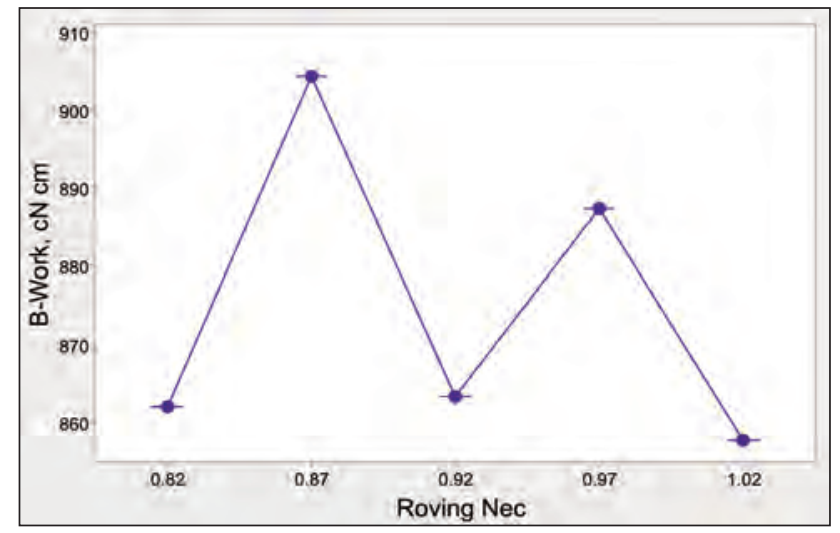

Fig. 5. Comparison of B-work 
$5.4 \%$ greater B-Work values compared to $1.02 \mathrm{Nec}$ sample. Samples produced from $0.87 \mathrm{Nec}$ roving showed over all better tensile properties then all other samples (figure 5).

\section{CONCLUSION}

The properties of yarn produced from five different linear density rovings $(0.82,0.87,0.92,0.97$ and 1.02 $\mathrm{Nec})$ were investigated. It is concluded that:

- $16 \mathrm{Nec}$ yarn produced from $0.97 \mathrm{Nec}$ roving improved the irregularity compared to other sam- ples, it also gave the least number of thin places and Neps.

- IPI of yarn decreases with the decrease in the linear density of roving. $1.02 \mathrm{Nec}$ roving gave better results compared to other samples.

- $0.87 \mathrm{Nec}$ yarn samples were found to be most effective in terms of tensile properties.

It is also concluded that $0.87 \mathrm{Nec}$ roving are most effective for achieving better tensile properties of $16 \mathrm{Nec}$ yarn. However $16 \mathrm{Nec}$ yarn produced from $1.02 \mathrm{Nec}$ roving was most effective in terms of IPI and $0.97 \mathrm{Nec}$ is most effective in terms of $\mathrm{U} \%$.

\section{BIBLIOGRAPHY}

[1] Klein, W. The technology of short staple spinning. 1987, In: The Textile Institute, p. 2.

[2] Hasani, H., Tabatabaei, S. and Semnani, D. Determining the optimum spinning conditions to produce the rotor yarn from cotton wastes. In: Industria Textila, 2010. 61(6): pp. 259-264.

[3] Klein, W. A practical guide to combing, drawing and the roving frame 2000. In: The Textile Intitute, p. 43.

[4] Kumar, A., et al. Impact of different stages of spinning process on fibre orientation and properties of ring, rotor and air-jet yarns: Part 1- Measurements of fibre orientation parameters and effect of preparatory processes on fibre orientation and properties. In: Indian Journal of Fibre \& Textile Research 2008. 33(4): pp. 451-467.

[5] Balasubramanian, N. A atudy of the irregularities added in apron drafting. In: Textile Research Journal, 1969. 39(2): pp. 155-165.

[6] Nemzer, G.M. Reducing irregularity in sliver, roving and yarn. In: Tech Text Ind USSR, 1961, 2: pp. 66-73.

[7] Furter, R. Measurement of slub yarns with the USTER TESTER 4, 2003.

[8] Nutter, W. Removal of fiber hooks by roller drafting. In: Textile Research Journal, 1962. 32(5): pp. 430-431.

[9] Ghosh, G.C. and Bhaduri, S.N. Dependence of hook removal at drawing on some drafting parameters. In: Textile Research Journal, 1962. 32(10): pp. 864-866.

[10] Lawrence, C.A. Fundamentals of spun yarn technology. In: CRC Press, 2003.

[11] Merchant, V.B. Theoretical aspects of hook removal at drafting operations. In: Textile Research Journal, 1961. 31(11): pp. 925-931.

[12] Woods, H.J. Properties of textile materials. In: Journal of the Textile Institute Proceedings, 1953. 44(2): pp. P39-P47.

[13] Morton, W.E. and Hearle, W.S. Physical properties of textile fibres. In: 4th ed. 2008: Woodhead Publishing Limited Cambridge, England.

[14] Saville, B.P. Physical testing of textiles. In: 1999: Woodhead Publishing Limitted Cambridge, England.

[15] Booth, J.E. Principles of textile testing. In:1969: Chemical Publishing New York.

[16] Pan, N. Analysis of woven fabric strengths: Prediction of fabric strength under uniaxial and biaxial extensions. In: Composites Science and Technology, 1996, 56(3): pp. 311-327.

[17] Majumdar, A., Majumdar, P.K. and Sarkar, B. Application of an adaptive neuro-fuzzy system for the prediction of cotton yarn strength from HVI fibre properties. In: The Journal of The Textile Institute, 2005. 96(1): pp. 55-60.

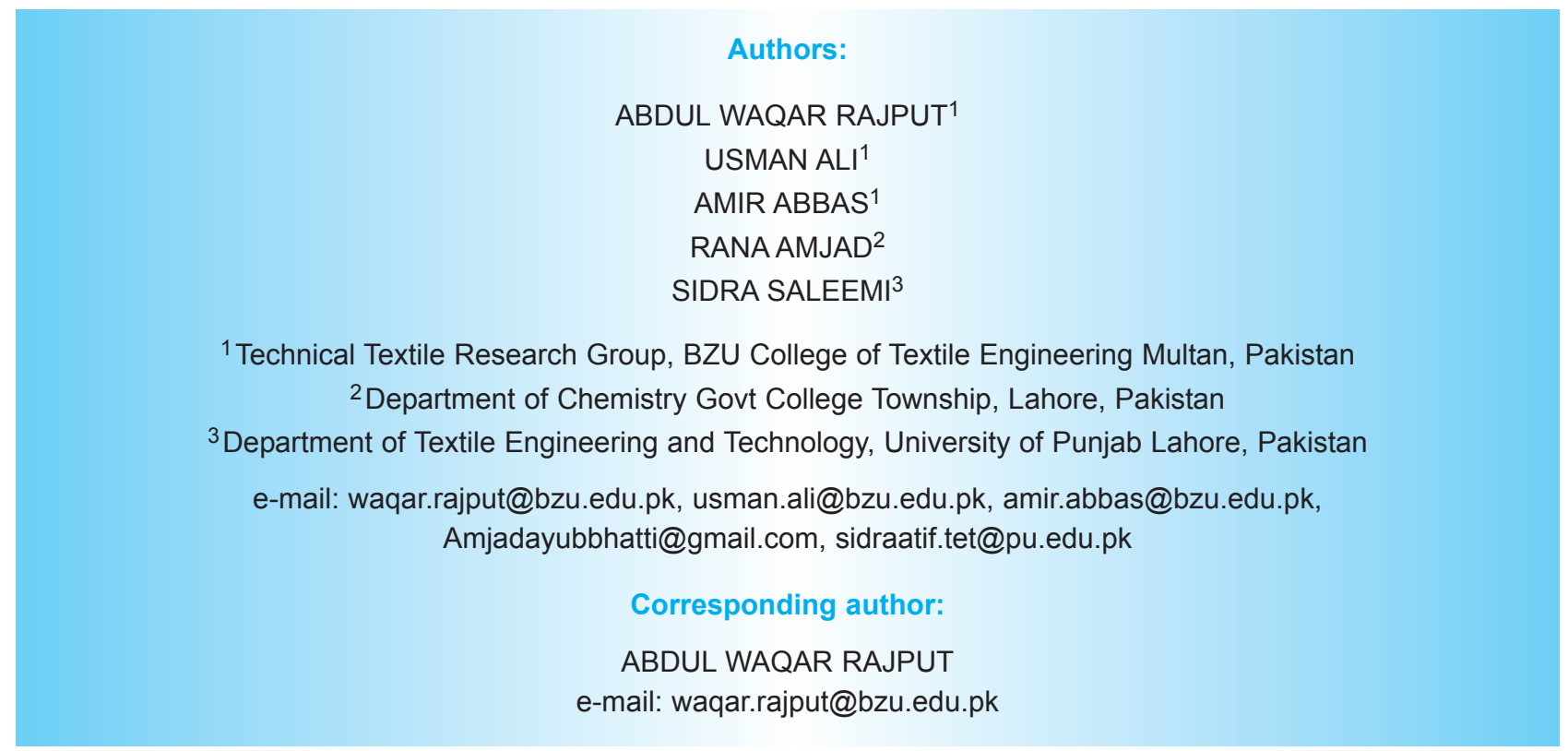




\title{
Analysis on the influence of the use of recovered textiles on the acoustic properties of composite materials
}

\author{
DOI: $10.35530 / I T .068 .06 .1463$
}

IULIANA IAŞNICU (STAMATE)

VIVIANA FILIP

GHEORGHIȚA TOMESCU

SIMONA MIHA

OVIDIU VASILE

\author{
REZUMAT - ABSTRACT
}

\section{Analiza influenței utilizării materialelor textile recuperate asupra proprietăților acustice} ale materialelor compozite

Prezenta lucrare contribuie cu soluții de valorificare a unor deşeuri textile în reducerea zgomotului la locul de muncă. Reducerea nivelului de zgomot din sectiile de productie se poate face şi prin carcasarea sursei de zgomot, în principal a motorului şi a transmisiilor către organele de lucru, cu plăci de materiale în structură simplă sau în structură compozită. Prin testarea mai multor tipuri de plăci stratificate din materiale compozite, conținând un strat din deşeuri textile, s-au stabilit valorile coeficienților de absorbție fonică, s-a determinat nivelul presiunii acustice și a factorului de directivitate pentru zgomotul de fond și eficiența acestor materiale ca izolatoare fonice.

Utilizarea materialelor compozite stratificate studiate, în domeniul reducerii zgomotului industrial, ca factor de risc important, ajută la îndeplinirea cerințelor de protecție a mediului (prin reutilizarea deşeurilor textile) şi a omului (prin reducerea nivelului de zgomot în clădirile industriale).

Cuvinte-cheie: plăci din materiale textile recuperate, proprietăți fonoabsorbante

\section{Analysis on the influence of the use of recovered textiles on the acoustic properties of composite materials}

This paper comes to bring ways of harnessing the noise reduction properties of textile waste in the workplace. Noise reduction from the production sections can be achieved by encapsulating the noise source, mainly the engine and transmission to the components of work using plates of material in simple structure or composite structure.

By testing multiple types of composite laminated plates containing a layer of textile waste, sound absorption coefficient values, determination of sound power and directivity characteristic full sound sources and effectiveness of these materials as soundproofing were established.

Using these studied layered composite materials in the field of industrial noise reduction, as an important risk factor, helps to meet the requirements of environmental protection (by reusing waste textiles) and human protection (by reducing noise in industrial halls).

Keywords: recovered textile fiber plate, sound-absorbing properties

\section{INTRODUCTION}

Noise is a risk factor that has harmful effects on the human body, depending on the level of intensity noise, spectral component, duration and distribution of noise exposure during a working day, the total lifetime exposure [5]. The action may lead to harmful noise: auditory organ disorders; disorders of various organs and body apparatuses; reduce labor productivity; reduce the intelligibility of speech [6]. Daily noise exposure limit at work is $87 \mathrm{~dB}(\mathrm{~A})$.

For a sustainable development of the automotive industry, in this case - textile industry, it is necessary to pursue a solution in support of a better life, by removing textile waste, which returned to a specific manufacturing process becomes plates textiles and aims to obtain laminated composite materials with this textiles plates, used to encapsulate industrial noise sources and so to obtain noise reduction to work [1-4].

Have been studied textile plates made of recovered textile fiber (woolen and synthetic fibers), in terms of absorbing properties [1-3].

\section{PRESENTATION OF THE MEASURING SYSTEM AND THE TYPES OF MATERIALS}

For the experiment there were necessary: Reading impedance tube type 4206 A, Brüel \& Kjaer 2 microphones, type 4187 (figure 1); a signal generator; a power amplifier type 2716-C; PULSE acquisition system with 5 channels and a PC with software control and data acquisition PULSE v12,5. Specialized software license: PULSE, Acoustic testing material in the tube, type 7758 is used to determine the acoustic characteristics of materials. Acoustic measurements are made in the frequency $100 \mathrm{~Hz} \div 3.2 \mathrm{kHz}[23,24]$. Reading impedance tube type 4206 has 2 microphones so that they can measure the sound absorption coefficient, reflectivity acoustic impedance ratio in the ranges given above $(100 \mathrm{~Hz}$ and $3.2 \mathrm{kHz})$. The measurement method is in accordance with standard EN ISO 10534-2 which states the conditions for using acoustic interferometer (Kundt tube) [23].

Out the measurements: atmospheric pressure $1035.00 \mathrm{hPa}$, temperature $-28.00^{\circ} \mathrm{C}$, relative humidity $-46.00 \%$, sound speed $-347.89 \mathrm{~m} / \mathrm{s}$, air density - $1195 \mathrm{~kg} / \mathrm{m}^{3}$, air characteristic impedance: 415.8 $\mathrm{Pa} /(\mathrm{m} / \mathrm{s})$. 


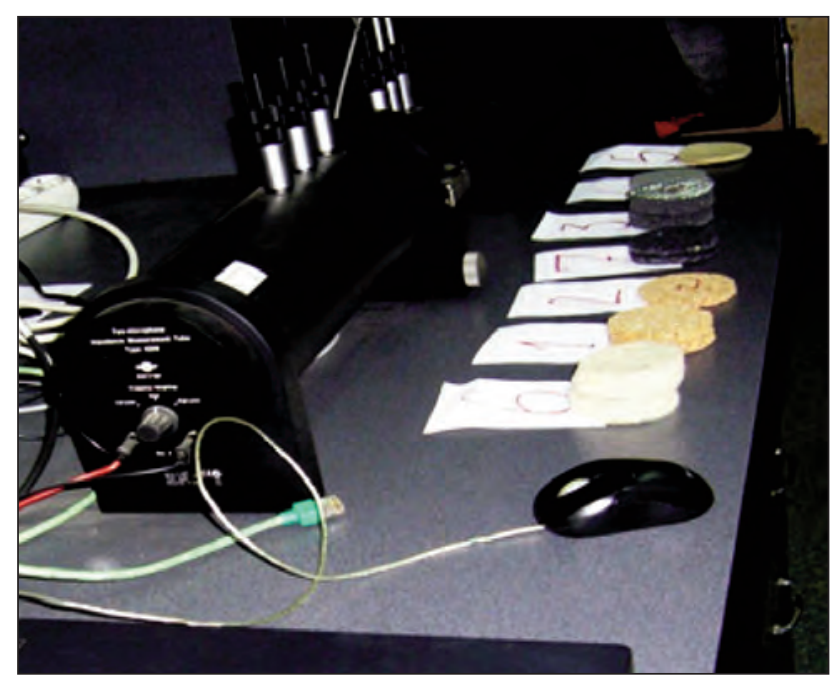

Fig. 1. Tube type 4206 A for impedance reading

Were studied more types of material, of which two types of materials subject of this study:

- Plate fabric made of recovered textile fiber: woolen with the thickness of $3 \mathrm{~mm}-\mathbf{P} \mathbf{5}$; (figure 2, a);

- woolen with the thickness of $10 \mathrm{~mm}-\mathbf{P} \mathbf{6}$; (figure 2, b);

- comprising $85 \%$ short PNA plus $15 \%$ fiber PA or $\mathrm{PE}$, or the first use recovered fiber, material thickness $10 \mathrm{~mm}-\mathbf{P} 7$ (figure 2, $\mathrm{c}$ ).

After that there were studied the results of the acoustic properties of presented materials that best soundinsulating material is synthetic material $P 7$, which joined other studied materials recognized as soundinsulating materials and a composite material was obtained which is studied in terms of the same features. Types of boards (cork, polyethylene, polystyrene).

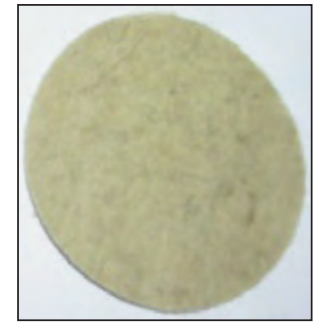

a

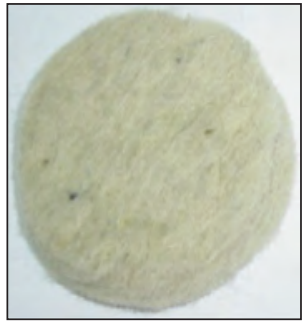

b

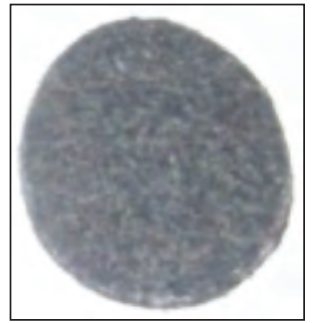

c
Fig. 2. Sample taken from: a) \& b) plate recovered textile - wool and c) plate recovered textile - synthetic

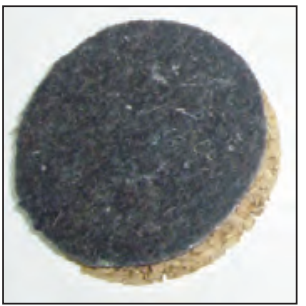

a

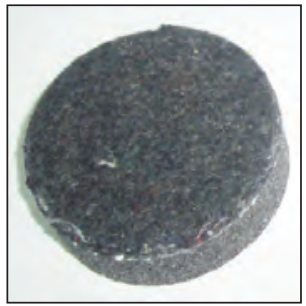

b

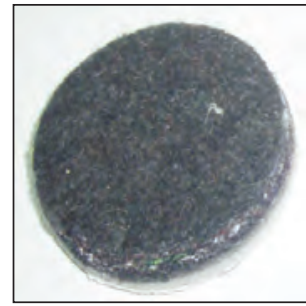

c
Fig. 3. Sample taken from: plate recovered textile a) and cork; b) and polyethylene; c) and polystyrene
SCALE CHARACTERISTIC SOUND ABSORBING MATERIALS

The sound absorption coefficient $\alpha_{i}$ occurs if the area of separation of the two media there is a dissipation of acoustic energy; then the amount of energy that is not reflected is considered absorbed.

$$
\alpha_{i}=1-\frac{\Phi_{r}}{\Phi_{i}}
$$

where: $\Phi_{r}$ is reflected acoustic energy flow; $\Phi_{i}-$ incident energy flow.

In other words sound absorption coefficient is defined as the sound energy absorbed $E_{a}$ by the environment passing wave and incident wave energy $E_{i}, E_{r}$ is the energy of the reflected wave $[25,26]$.

or

$$
\alpha=\frac{E_{a}}{E_{i}}
$$

$$
\alpha=1-\left(\frac{E_{r}}{E_{i}}\right)
$$

Reflections are characterized by the reflectivity or reflection factor acoustics. The reflection coefficient is given by the ratio between the amplitude of the reflected wave and the incident wave amplitude. Sound wave is a pressure wave, acoustic reflectivity can write the relation [24-26]:

$$
r=\frac{P_{r}}{P_{i}}
$$

It is obtained the relationship between sound absorption coefficient and the reflection coefficient of the sound, namely:

$$
\alpha=1-r^{2}
$$

The medium sound absorption coefficient, calculated for an enclosure/housing with $S_{i}$ inner surfaces and sound absorption coefficients can be calculated as:

$$
\alpha_{\text {med }}=\frac{\sum \alpha_{i} \cdot S_{i}}{\Sigma S_{i}}
$$

The constant of absorption $R$ of the room is calculated using the equation:

$$
R=\frac{S \cdot \alpha_{\text {med }}}{1-\alpha_{\text {med }}} \quad\left[\mathrm{m}^{2}\right]
$$

where: $S$ is the total area of the walls of the room (in this case the cubic enclosure with sides $0.7 \mathrm{~m}$ )

\section{EXPERIMENTAL RESULTS}

Using Tube Brüel \& Kjaer type 4206 A, for impedance reading there are obtained experimental data of sound absorption coefficient (table 1). In order to track the influence of material thickness are analyzed separately cork (figure 3 ) and textiles (figure 4), and obtained graphs for a better view. 


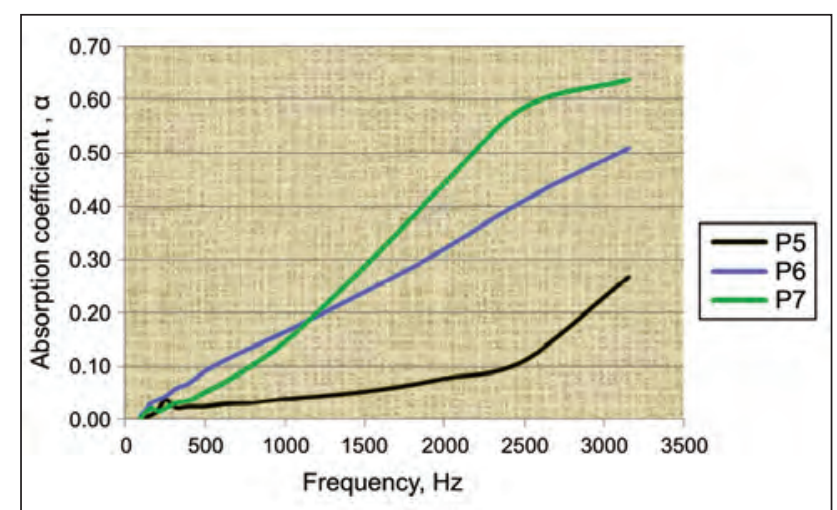

Fig. 4. Absorption coefficient curves for the textiles materials

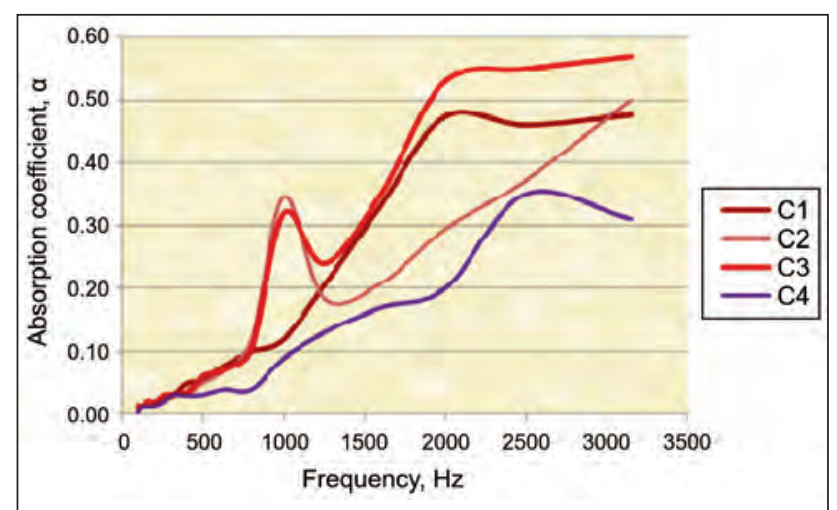

Fig. 5. Variation absorption coefficient for composite materials studied: C1, C2, C3, C4
Table 1

SOUND ABSORPTION CLASS $[18,27]$

\begin{tabular}{|c|c|}
\hline Absorption coefficient $\alpha$ & Sound Absorption Class \\
\hline $0.90-1.00$ & A \\
\hline $0.80-0.85$ & $B$ \\
\hline $0.60-0.75$ & C \\
\hline $0.30-0.55$ & $D$ \\
\hline $0.15-0.25$ & E \\
\hline $0.00-0.10$ & Not classified \\
\hline
\end{tabular}

The thickness of the materials is a crucial factor influencing directly proportionally the absorbing properties: the more the thickness of the material increases, the more its ability to absorb sound waves increases. Analyzing the results of the absorption coefficient (figure 4) it is shown that textile plates have sound absorption characteristics. About these plates textile waste, it is concluded that the thickness of $10 \mathrm{~mm}$ can be used in sound insulation, sound absorption reaching Class $D$ (table 2), with values $\alpha_{m}=0.33$ for plate wool recovered fibers and $\alpha_{m}=0.39$ plate obtained from synthetic recovered fibers. Up to $1000 \mathrm{~Hz}$ sample P 6, which is made of short fibers of wool, having a plate thickness of $10 \mathrm{~mm}$, has the highest values of the coefficient of absorption, so the frequency range between 0 and $1000 \mathrm{~Hz}$ the material behaves best in terms of sound absorption of the materials studied. Essential differences of curves analysis between $1000 \mathrm{~Hz}$ and $3150 \mathrm{~Hz}$, taking even a landmark namely intermediate frequency $2000 \mathrm{~Hz}$ : P $6-\alpha_{i}$ has a value of 0.32 and $P 7-\alpha_{i}$ sample has a value of 0.44 . Better sound-absorbing qualities of the sample $P 7$ is manifested by a more rapid increase of absorption coefficient both in the frequency range 1000 to $2000 \mathrm{~Hz}$, from 0.15 to 0.44 and further the range of $2000-3150 \mathrm{~Hz}$ from 0.44 to 0.64 . Of all the plates obtained from MTR, synthetic fiber plate has the best sound-absorbing behavior.

Analyzing the experimental data obtained for composite materials, plot a graph for all samples of laminated composite materials, figure 5 to seeing the differences and variations of sound absorption coefficient versus frequency (table 2). In all cases studied, the direct interaction of surface acoustic waves consists of textile waste material.

There is a directly proportional increase sound absorption coefficient by increasing frequency for all cases analyzed.

Value weighted average $\alpha_{\mathrm{m}}$ sound absorption is 0.371 for the case composite $\mathrm{C} 1 \alpha_{\mathrm{m}}$ is 0.307 for the case $C 2$ and $\alpha_{m}$ is 0.401 for the case $C 3$ and 0.186 for the composite $\mathrm{C} 4$, thus making it possible inclusion of composite materials laminated C 1-C 3 absorption class $D$ and for composite material $C 4$ falling within absorption class $\mathrm{E}$.

In the range $1250-2000 \mathrm{~Hz}$ there is a continuous increase of sound absorption coefficient for all cases studied: where C 1 and the case C3 growth is accelerated and manifest until around $2000 \mathrm{~Hz}$, where the curve variation of sound absorption will grow much slower; curve showing an image almost stationary on

Table 2

\begin{tabular}{|c|c|c|c|c|c|c|}
\hline \multicolumn{7}{|c|}{ AVERAGE SOUND ABSORPTION COEFFICIENT $\alpha_{m}$} \\
\hline \multirow{2}{*}{ Case } & \multirow{2}{*}{$\begin{array}{l}\text { Material } \\
\text { structure }\end{array}$} & \multicolumn{3}{|c|}{ Sound absorption coefficient $\alpha_{i}$} & \multirow{2}{*}{$\alpha_{m}$} & \multirow{2}{*}{$\boldsymbol{R}$} \\
\hline & & $800 \mathrm{~Hz}$ & $2000 \mathrm{~Hz}$ & $3200 \mathrm{~Hz}$ & & \\
\hline C 1 & Textile material + cork & 0,100 & 0,474 & 0,539 & 0,371 & 1,73 \\
\hline C 2 & Textile material + polyethylene $+\mathrm{Al}$ & 0,119 & 0,295 & 0,508 & 0,307 & 1,30 \\
\hline C 3 & Textile material + expanded polyethylene & 0,103 & 0,528 & 0,572 & 0,401 & 1,97 \\
\hline C 4 & Textile material + extruded polystyrene & 0,041 & 0,207 & 0,311 & 0,186 & 0,67 \\
\hline
\end{tabular}


the frequency $2000-3200 \mathrm{~Hz}$. For the case of $\mathrm{C} 2$ increase is linear, continuous, up to the end of the measurement interval, at $3200 \mathrm{~Hz}$. Case C 4 increase occurs up to the $2500 \mathrm{~Hz}$, which reaches a maximum of 0.353 of which is a decrease by the end of the measuring range, where $\alpha=0.311$.

The maximum values of sound absorption coefficient obtained in the first three cases meet the full extent of the field measured at $3200 \mathrm{~Hz}$ : 0.539 case C 1; 0.508 to case $\mathrm{C} 2$ and 0.572 corresponding on case C 3 .

\section{STUDY RESULTS FOR ENCAPSULATION OF NOISE SOURCES}

Using what was once sought to be obtained composite materials, is to achieve industrial noise encapsulation sources. This study was conducted in Polytechnic University of Bucharest, anechoic room acoustics - Department of Mechanical Laboratories. In the case of free acoustic field, conducted in anechoic chamber, representing $L_{W A}$ weighted sound power level is calculated from $L_{p m}$ - the average sound pressure measurement surface $S$, using the relationship [18, 19, 20]:

$$
L_{W A}=L_{p m}+10 \lg \left(\frac{S}{S_{0}}\right)+K, \quad[\mathrm{~dB}(\mathrm{~A})]
$$
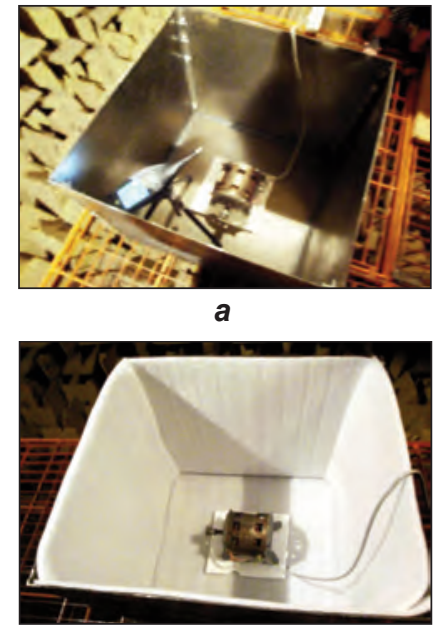

c

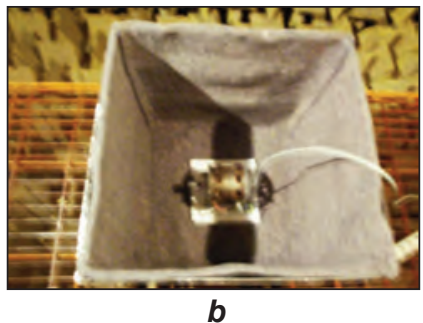

b

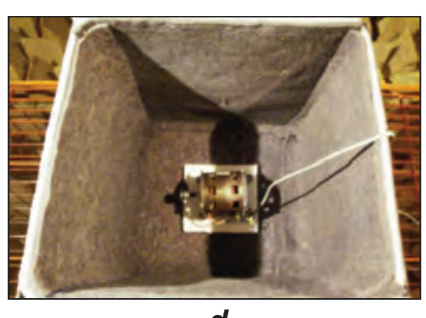

d
Fig. 6. Experiment in anechoic chamber: $a-$ metal cube which encloses the motor housing; $b$ - cube lined with textile waste plate; $c$ - cube lined with polyethylene plate; $d$-cube lined with plate of composite material comprising polyethylene and textile recovered material

$$
L_{p m}=\frac{1}{8} \sum_{i=1}^{8} L_{p i},
$$

Where: $S_{0}=1 \mathrm{~m}^{2}$ is the area of the reference surface;

$S=\pi r^{2}=3,14 \mathrm{~m}^{2}$ if it studied the situation when $r=1 \mathrm{~m}$;

$K$ is the correction coefficient of the ambient pressure and temperature reference conditions of $20^{\circ} \mathrm{C}$ and $1000 \mathrm{~Pa}$; it choose $K=0$.

$$
L_{W A}=L_{p m}+10 \lg 3,14=L_{p m}+4,97
$$

Weighted sound pressure level is calculated using relationship [20]:

$$
L_{p m A}=10 \log \left(\frac{1}{n} \sum_{i=1}^{n} 10^{0,1 \cdot L_{p i A}}\right), \quad[\mathrm{dB}(\mathrm{A})]
$$

where: $L_{\text {piA }}$ they are weighted sound pressure $A$, in $\mathrm{dB}(\mathrm{A})$, for the $n$ measurement points.

Determination of directivity curve: the sound field corresponding to a directional sound sources can be characterized by a directivity factor $D_{\theta i}$ source, or a directivity index $d q$. For omnidirectional source located in the open field there is the following relationship linking the sound pressure level and power level [20]:

$$
L_{p}=L_{W}-20 \cdot \log d-11, \quad[\mathrm{~dB}(\mathrm{~A})]
$$

where: $d$ is source-receiver distance, $[\mathrm{m}] ; d=1 \mathrm{~m}$.

For omnidirectional source located in the open field, each doubling of the distance the sound level decreases by $6 \mathrm{~dB}$. In the case of free acoustic field, conducted in anechoic chamber, sound pressure level measured in the eight-point lead directivity factor calculation with formula [20]:

$$
D_{\theta i}=L_{p i}-L_{W}+20 \cdot \log d+11
$$

where: $D_{\theta i}$ are directivity factor, dimension less unit.

\section{Determination of sound power and directivity} characteristic of full sound sources

The point of minimum pressure and minimum directivity factor are P 2 and the point where they get maximum value in $P 7$. Mean sound pressure level is $45.97 \mathrm{~dB}$ and value-weighted sound power level $L_{W A}=50.94 \mathrm{~dB}$. There is a considerable attenuation of acoustic power of about $9 \mathrm{~dB}$ (tables 3, 4)

For sample P II - engine in cubic metal + recovered textile plate observed are maintained as a

\begin{tabular}{|c|c|c|c|c|c|c|c|c|c|c|}
\hline \multicolumn{10}{|c|}{ EXPERIMENTAL RESULTS FOR WEIGHTED SOUND POWER } \\
\hline Sample & $L_{p 1}$ & $L_{p 2}$ & $L_{p 3}$ & $L_{p 4}$ & $L_{p 5}$ & $L_{p 6}$ & $L_{p 7}$ & $L_{p 8}$ & $L_{p m}$ & $L_{\boldsymbol{~} \boldsymbol{p}}$ \\
\hline P I & 46,13 & 43,84 & 45,85 & 44,80 & 46,62 & 47,07 & 47,44 & 45,99 & 45,97 & 50,94 \\
\hline P II & 34,50 & 32,08 & 35,22 & 34,08 & 36,91 & 34,65 & 38,67 & 34,08 & 35,02 & 39,99 \\
\hline P III & 42,93 & 42,63 & 39,97 & 43,60 & 48,08 & 44,85 & 43,14 & 41,81 & 43,37 & 48,34 \\
\hline P IV & 37,02 & 36,60 & 34,44 & 33,87 & 34,63 & 30,06 & 35,27 & 35,50 & 34,67 & 39,64 \\
\hline
\end{tabular}


CALCULATION OF DIRECTIVITY SAMPLE P I - ENGINE CASING METAL CUBE

\begin{tabular}{|c|c|c|c|c|c|c|c|c|}
\hline Measuring point & P 1 & P 2 & P 3 & P 4 & P 5 & P 6 & P 7 & P 8 \\
\hline$\theta_{i}$ & $0^{\circ}$ & $45^{\circ}$ & $90^{\circ}$ & $135^{\circ}$ & $180^{\circ}$ & $225^{\circ}$ & $270^{\circ}$ & $315^{\circ}$ \\
\hline$L_{p i}$ & 46,13 & 43,84 & 45,85 & 44,80 & 46,62 & 47,07 & 47,44 & 45,99 \\
\hline$D_{\theta i}$ & 6,19 & 3,90 & 5,91 & 4,86 & 6,68 & 7,13 & 7,50 & 6,05 \\
\hline
\end{tabular}

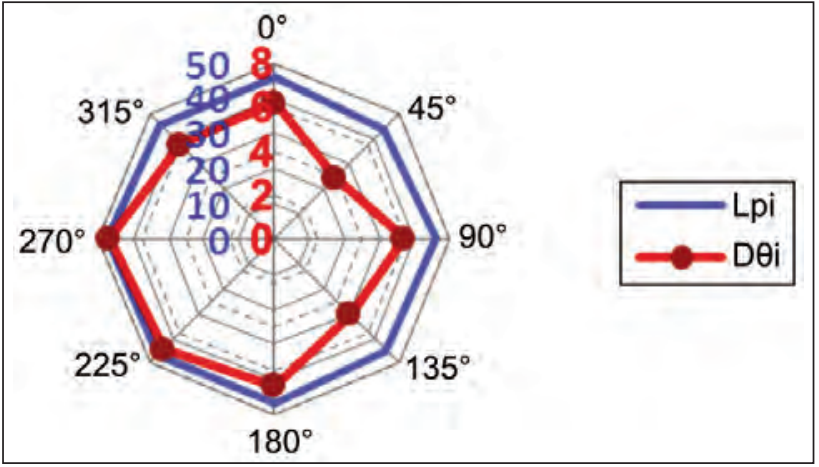

Fig. 7. Directivity factor for the sample P I, depending on $\theta i$ and the function $L p i$

minimum point $P 2$ and the maximum point $P 7$ directivity curve showing approximately the same shape. Mean sound pressure level is $35.02 \mathrm{~dB}$ and weighted sound power level $L_{W A}=39.99 \mathrm{~dB}$. For both sizes is a significant reduction in the values obtained by calculation, with increasing thickness which casing engine (table 5). Also, it is emphasized that the plates of textile materials recovered are indicated for use in this end of casing noise sources. There is a considerable attenuation of acoustic power of about $11 \mathrm{~dB}$. For sample P III - metallic cube engine + EPE plate, change points are reached peaks namely the minimum directivity is observed that point $\mathrm{P} 3$ and maximum on $P 5$. Mean maximum point of sound pressure level is $43.37 \mathrm{~dB}$ and weighted sound power level is $L_{W A}=48.34 \mathrm{~dB}$ (table 6). The waveform is changed this time, and reducing the values for

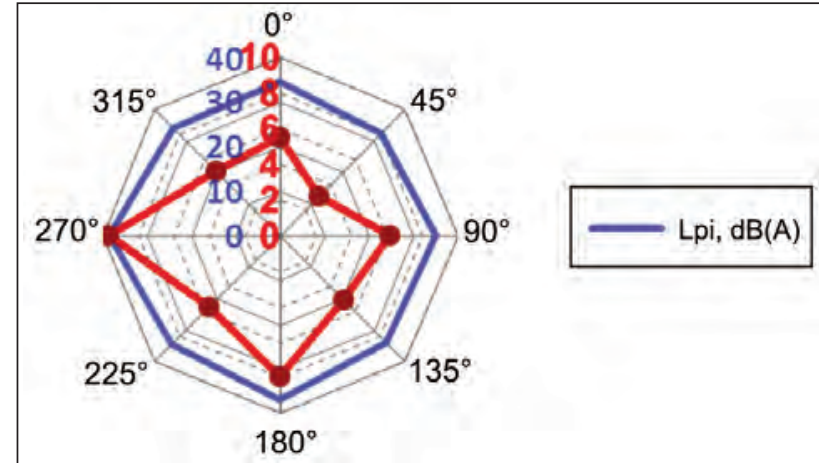

Fig. 8. Directivity factor for the sample P II, according $\theta i$ and the function $L p i$

the calculated versus the engine casing only with a cube of metal, does not show a reduction as high as in the case of using recovered textile sheet material. For sample P IV - metallic cube engine + plate MTR synthetic + EPE board change points are reached peaks namely the minimum directivity is observed that point $P$ 1. Mean maximum point of sound pressure level is $34.67 \mathrm{~dB}$ and weighted sound power level $L_{W A}=39.64 \mathrm{~dB}$ (table 7). The waveform changes this time and reducing the values for the calculated versus encapsulation engine only with a metal cube, is significant. There is a considerable attenuation of acoustic power level of about $11.5 \mathrm{~dB}$.

Between the four options studied in this paper, the sample P IV which uses the combination of extruded polystyrene and textile material recovered for enclosure a sound source, obtain the best sound power level reduction.

Table 5

CALCULATION OF DIRECTIVITY SAMPLE P II - ENGINE CASING CUBE + RECOVERED TEXTILE PLATE

\begin{tabular}{|c|c|c|c|c|c|c|c|c|}
\hline Measuring point & P 1 & P 2 & P 3 & P 4 & P 5 & P 6 & P 7 & P 8 \\
\hline$\theta_{i}$ & $0^{\circ}$ & $45^{\circ}$ & $90^{\circ}$ & $135^{\circ}$ & $180^{\circ}$ & $225^{\circ}$ & $270^{\circ}$ & $315^{\circ}$ \\
\hline$L_{p i}$ & 34,50 & 32,08 & 35,22 & 34,08 & 36,91 & 34,65 & 38,67 & 34,08 \\
\hline$D_{\theta i}$ & 5,51 & 3,09 & 6,23 & 5,09 & 7,92 & 5,66 & 9,68 & 5,09 \\
\hline
\end{tabular}

Table 6

CALCULATION OF DIRECTIVITY SAMPLE P III - ENGINE CASING METAL CUBE + EPE PLATE

\begin{tabular}{|c|c|c|c|c|c|c|c|c|}
\hline Measuring point & P 1 & P 2 & P 3 & P 4 & P 5 & P 6 & P 7 & P 8 \\
\hline$\theta_{i}$ & $0^{\circ}$ & $45^{\circ}$ & $90^{\circ}$ & $135^{\circ}$ & $180^{\circ}$ & $225^{\circ}$ & $270^{\circ}$ & $315^{\circ}$ \\
\hline$L_{p i}$ & 42,93 & 42,63 & 39,97 & 43,60 & 48,08 & 44,85 & 43,14 & 41,81 \\
\hline$D_{\theta i}$ & 5,59 & 5,29 & 2,63 & 6,26 & 10,74 & 7,51 & 5,80 & 4,47 \\
\hline
\end{tabular}


CALCULATION OF DIRECTIVITY SAMPLE P IV - ENGINE CASING METAL CUBE + RECOVERED TEXTILE PLATE + EPE PLATE

\begin{tabular}{|c|c|c|c|c|c|c|c|c|}
\hline Measuring point & P 1 & P 2 & P 3 & P 4 & P 5 & P 6 & P 7 & P 8 \\
\hline$\theta_{i}$ & $0^{\circ}$ & $45^{\circ}$ & $90^{\circ}$ & $135^{\circ}$ & $180^{\circ}$ & $225^{\circ}$ & $270^{\circ}$ & $315^{\circ}$ \\
\hline$L_{p i}$ & 37,02 & 36,60 & 34,44 & 33,87 & 34,63 & 30,06 & 35,27 & 35,50 \\
\hline$D_{\theta i}$ & 8,38 & 7,96 & 5,80 & 5,23 & 5,99 & 1,42 & 6,63 & 6,86 \\
\hline
\end{tabular}

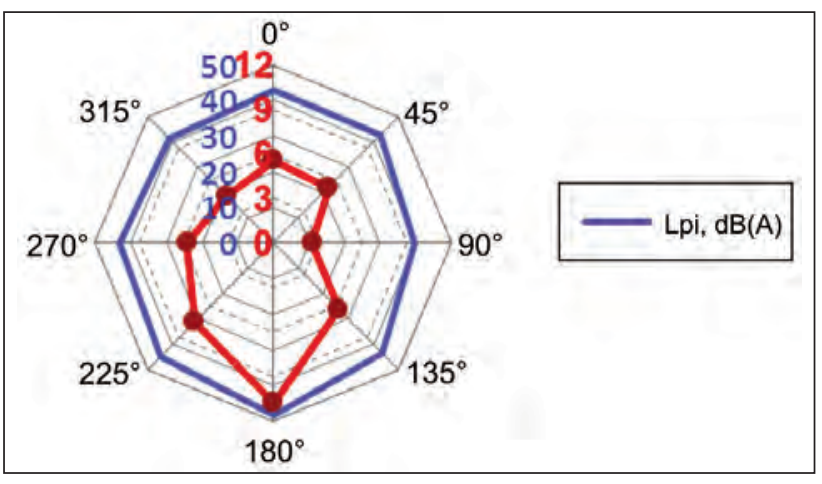

Fig. 9. Directivity factor for the sample P III, depending on $\theta i$ and the function $L p i$

\section{CONCLUSIONS}

Using these types of recyclable materials the fundamental requirement of sustainable resource use worldwide is satisfied. Sound-absorbing materials used in this study are formed on the basis of recyclable textile materials which have a low manufacturing cost, so that the composite materials obtained can be used in an efficient and low-priced. Of composite materials studied it can be concluded that the most appropriate to the aim pursued, the composite layer $\mathrm{C} 3$ consists of plate recoverable synthetic textile + expanded polyethylene plate.

The sound absorption capacity of the materials recovered from textile fibers in combination with polyethylene expanded is considerably high, as can be seen in figure 5 , the composite $\mathrm{C} 3$.

By using the combined structure of the materials which have different absorption coefficients, a solution of efficient acoustic encase with a substantial reduction of the sound power generated by an electric motor is obtained.

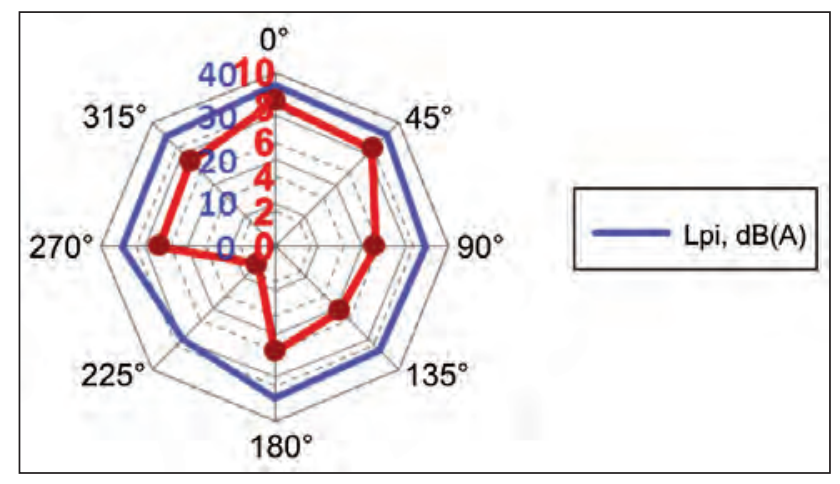

Fig. 10. Directivity factor for the sample P IV, depending on $\theta i$ and the function $L p i$

The optimal encapsulation solution (see figure 10) obtained from the research presented in this paper, can be adapted for other noise sources with different overall dimensions, being able to increase or decrease the casing size used if necessary.

The use of these types of materials in simple structure or innovative composite structure, based on textile fiber waste, turns out to be a very efficient alternative compared to existing materials on the market at this time.

\section{ACKNOWLEDGEMENT}

The authors acknowledge the support of the Polytechnic University of Bucharest, Department of Mechanic, Laboratory of Acoustics and Vibration, where experimental tests have been achieved.

The determinations of mechanical strength and structure on studied material samples were made at the Multidisciplinary Science and Technology Research Institute of Valahia University of Targoviste (Laboratory B05 - Prototyping and ecodesign in renewable energy systems - MTS Bionix Tabletop Test Systems and Laboratory C14 Materials used in energy conversion - Microscope Stemi 2000 C, produced by Zeiss).

\section{BIBLIOGRAPHY}

[1] Zamfir, M. Deşeuri textile - surse reale de materii prime (Textile Waste - real sources of raw materials), In: Publishing Hause Performantica, lasi, 2008.

[2] Cioară, I. Inginerie generală în textile pielărie (General engineering textile leather), Publishing House In: Performantica, lasi, 2007.

[3] *** Manualul Inginerului Textilist (Textile engineer book) vol. II, part A, Publishing House AGIR, Bucharest, 2003.

[4] Kubik, S. Zgomotul la locul de muncă, In: (Noise at Work), vol. II, Bratislava, 1986.

[5] Beranek, L. Problema zgomotului în industria textilă (The noise problem in the textile industry), In: Textile Industries, S.U.A., 134, no. 6, 1970, pp. 113-117, p. 144.

[6] Darabont, A. Mijloace moderne de combatere a zgomotului şi vibraților (Modern means of combating noise and vibration), In: Central Institute of Technical Documentation, Bucharest, 1971. 
[7] Hadăr, A. Structuri din compozite stratificate (Stratified Composite Structures), In: Publishing House AGIR, Bucharest, 2002.

[8] Alămoreanu, E., Constantinescu, D. M. Proiectarea placilor compozite laminate (The design of laminated composite plates), In: Publishing House Academiei Române, Bucuresti, 2005.

[9] Stamate I., Materiale compozite stratificate cu conținut textil (Composite laminated materials containing textile), In: Publishing House Aureo, Oradea, 2015.

[10] Tiuc, A., Vasile, O., Gabor, T. Determination of antivibrational and acoustical properties of some materials made from recycled rubber particles and sawdust, In: Romanian Journal of Acoustics and Vibration, vol. XI, no. 1, 2014, pp. 47-52

[11] Youneung, L., Changwhan, J. Sound absorption properties of recycled polyester fibrous assembly absorbers, In: Autex Research Journal, vol. 3, no. 2, 2003.

[12] Gheorghe, A., Borlea (Tiuc), A.E. Evaluation of absorbing performances for composite plates made from recycled waste, SISOM 2012 and Session of the commission of acoustics, Bucharest, 2012, pp. 307-313.

[13] Hh Zhou, B. Li, G. Huang, J. He A novel composite sound absorber with recycled rubber particles, In: Journal of Sound and Vibration, vol. 304, 2007, pp. 400-406.

[14] Terciu, O.M., Curtu, I., Cerbu, C., Stan, G.I. Research on mechanical properties of composites materials reinforced with lignocellulosic fibers, In: The 8th International Conference "Wood science and engineering in the third millenium", ICWSE, Brasov, Romania, 2011, pp. 345-352.

[15] Ersoy, S., Kucuk, H. Investigation of industrial tea-leaf-fibre waste material for its sound absorption properties, In: Applied Acoustics, vol. 70, 2009, pp. 215-220.

[16] Koizumi, T., Tsujiuchi, N., Adachi, A. The development of sound absorbing materials using natural bamboo fibers, High performance, In: WIT Press, 2002.

[17] Fatima, S., Mohanty, A.R. Acoustical and fire-retardant properties of jute composite materials, In: Applied acoustics, vol. 72, 2011, pp. 108-114.

[18] Curtu, I., Stanciu, M.D., Coşereanu, C, Vasile, O. Assessment of acoustic properties of biodegradable composite materials with textile inserts, In: Materiale plastice, vol. 49, no. I, 2012, pp. 68-72.

[19] Bratu, P. Tracing curves for the sound absorbing characteristics in case of composites consisting of textile materials, In: Romanian Journal Of Acoustics And Vibrations, vol. 4, no. 1, 2007, pp. 23-26.

[20] Nastac, S., Anghelache, D., Stanciu, M., Curtu, I., On acoustic panels with high performances for pollutant individual working place insulation, In: 8th International DAAAM Baltic Conference Industria Engeneering, Tallinn, Estonia, 2012, pp. 69-73.

[21] Anghelache, D. About phonic isolation of the mobile equipment cabin, In: The Annals of "Dunarea de Jos" University of Galati, Fascicle XIV Mechanical Engineering, vol. 1, 2008.

[22] Bratu, P., Dragan, N., Vasile, O. Experimental studies of sound absorption coefficient of composite materials used for acoustic treatments of the cabins, In the 11-th International Congress on Automotive and Transport Engineering CONAT 2010, Proceedings - Volume III “Automotive Vehicles and Environment”, 2010, pp. 177-181.

[23] EN ISO 10534-2:2005 Acoustics. Determination of sound absorption coefficient and acoustic impedance with the interferometer, Part 2. Transfer function method, 2005.

[24] Vasile, O., Gillich, G.R., Influence of absorbtion and insulation properties for phonic treatment of public works equipment, In: Analele Universitatii "Eftimie Murgu" Reşita, vol. XIX, no. 1, 2012, pp. 335-344.

[25] Bratu, P., Acustică interioară pentru constructii şi maşini (Indoor Acoustics for construction and equipment), In: Publishing House Impuls, Bucharest, 2002.

[26] Enescu, N., Magheti, I., Sârbu, M. A., Acustică tehnică (Technical acoustics), In: Publishing House ICPE, Bucharest, 1998.

[27] ISO 11654 Acoustics. Acoustic absorbers for use in buildings. Evaluation of acoustic absorption, 2002.

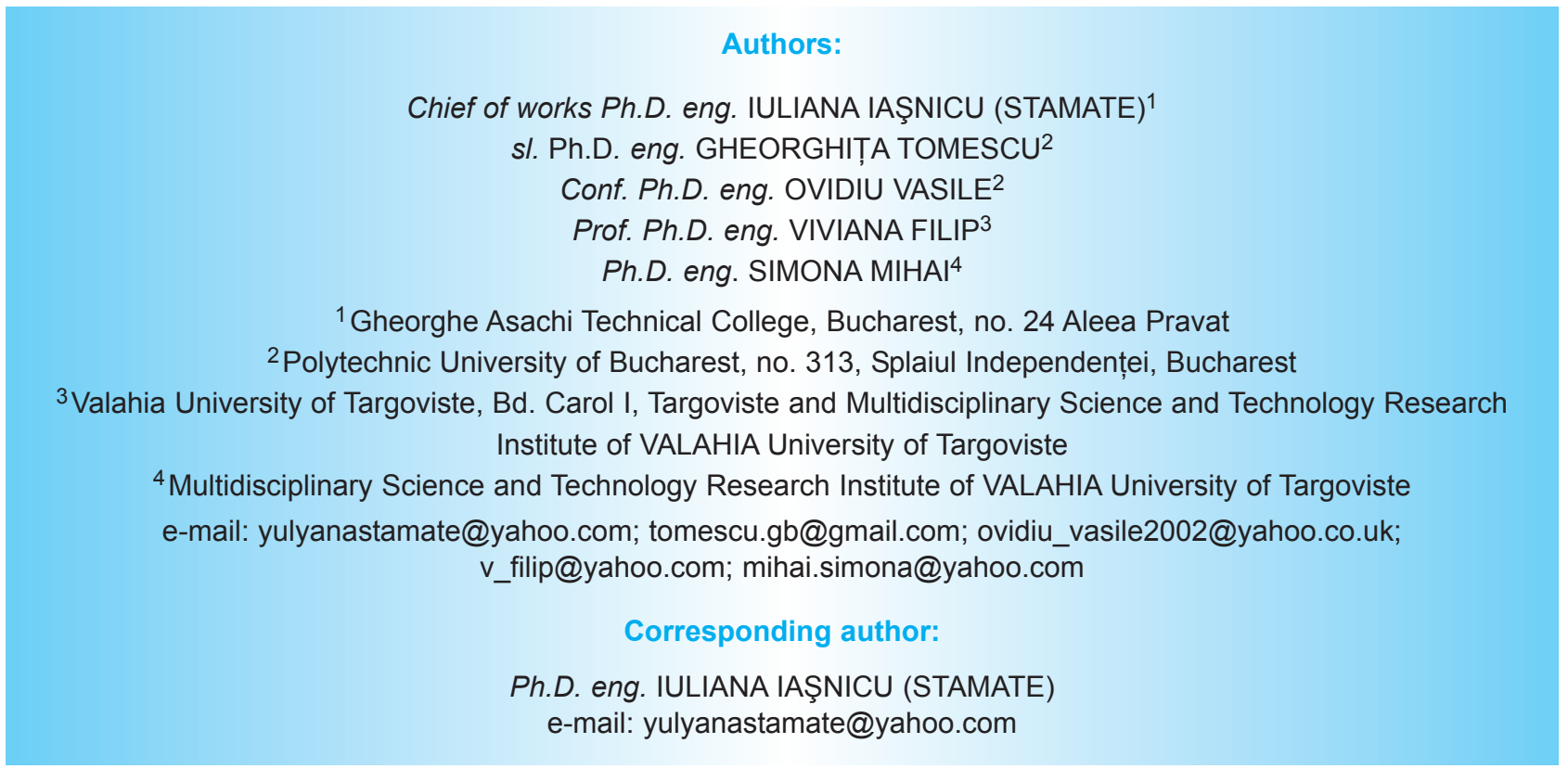




\section{Effect of the evaporation and knitting parameters on wicking behaviours: Experimental and analytical approaches}

\section{REZUMAT - ABSTRACT}

\section{Efectul parametrilor de evaporare şi tricotare asupra comportamentului de permeabilitate:}

abordări experimentale și analitice

În această lucrare, sunt prezentate rezultatele testelor din studiul experimental al comportamentelor de permeabilitate al materialelor tricotate. Se propune un model analitic pentru a preconiza efectul evaporării în testul de permeabilitate verticală, în funcție de parametrii de tricotare. Un dispozitiv experimental care efectuează suspensia verticală a suprafeței tricot-lichid și care permite pătrunderea moleculelor de apă prin aceste probe testate se utilizează în atmosferă saturată și nesaturată. Valorile experimentale ale permeabilității verticale în tricoturile care au fost măsurate gravimetric utilizând o micro balanță electronică au demonstrat că cinetica și înălțimea atinsă sunt influențate de parametrii de tricotare și de condițiile atmosferice (mediul saturat și nesaturat).

Cuvinte-cheie: comportament de permeabilitate, țesături tricotate, model analitic, evaporare

\section{Effect of the evaporation and knitting parameters on wicking behaviours: Experimental and analytical approaches}

In this paper, we reports the results of investigation related to the experimental study of wicking behaviours in knit fabrics. Then, analytical model is proposed to predict the effect of the evaporation in vertical wicking test depending upon knitting parameters. An experimental device performing the vertical suspension of fabric-liquid surface and permitting the penetration of water molecules through these tested samples is used in saturated and unsaturated atmosphere. Experimental values of vertical wicking in knit which were gravimetrically measured using an electronic microbalance demonstrated that the kinetic and the reached height are influenced by knitted fabric parameters and atmosphere conditions (saturated or unsaturated medium).

Keywords: wicking behaviours, knit fabrics, analytic model, evaporation

\section{INTRODUCTION}

Liquid flows in fabrics by capillary forces represent an important field of research as many applications in textiles processing industry which required several dozen of gallons of water, especially the preparation, dyeing and finishing processes. A large amount of literature is devoted to capillary transport but there is still a need for theoretical and fundamental research (mathematical models, numerical simulations, etc.) to fully understand the processes [1-8].

To obtain a better understanding of the liquid-textile contact and to model this problem of capillary rise, optimization of various processes involving liquidfibre contact, penetration of liquids into capillaries and textiles, and kinetic sorption of water onto textile fabric have been studied for many years [1-11]. Among the extensive research in the field of liquid transport and capillary rise initiated by Lucas and Washburn [12, 13], the fluid flow through porous media is modelled by the following well-known equation which allow determining the diffusion coefficient.

$$
h(t)=\sqrt{D t}
$$

Where, $h$ is the height of liquid rise into the tube; $D$ - the capillary rate coefficient. This coefficient is related at the same time to the capillary radius, the surface properties and viscosity of the liquid according to following equation:

$$
D=\frac{r \gamma \cos \theta}{2 \eta}
$$

Where, $\eta$ is the viscosity of the liquid, $\gamma$ - the surface tension of the liquid; and $\theta$ - the contact angle between the liquid and the inside surface of the capillary.

The main deficiency of this law is the fact that it can be applied as long as gravity forces are negligible, which means that, it is applicable only for short experimental time when the height attained by the liquid is very smaller than the height at equilibrium. That's why this law must be corrected. These discrepancies were partly overcome by many researchers $[1,2,14]$. In previous works we have studied the capillary flow in cotton and polyester fabrics using a generalized Lucas-Washburn equation, which was applicable for short and long experimental time, as shown below [1, 2].

$$
h \dot{h}=\frac{D}{2}\left(1-\frac{h}{h_{e}}\right)
$$

Where, $h_{e}$ is the height of liquid rise into the fabric at equilibrium. 
Equally, it was shown that this generalized model is valid when we neglect the influence of evaporation which is not usually the right case, in particular when we use water.

In this paper, attempts have been made to develop and validate mathematical models based on the Washburn law for predicting the evaporation phenomenon in vertical wicking test. Then, we study effect of knitting parameters and evaporation phenomenon on wicking and kinetic of water on textile structure.

\section{MATERIALS AND METHOD}

The fabric samples used in this study were knitted using the same machine. The samples were knitted by changing fabric structural parameters, such as the kind of yarn, the composition and the knit structure. Table 1 gives the knitting parameters and physical properties of each sample used in this study.

The dimension of the dry sample used in experiments was $20 \mathrm{~cm} \times 30 \mathrm{~cm}$. We used the distilled water which is used frequently in textile industry.

To remove the natural wax and paraffin oil that has been applied to yarns prior to knitting, a chemical treatment was used. The fabric was treated for 20 minutes at $65^{\circ} \mathrm{C}$ with a solution containing $2 \mathrm{~mL} / \mathrm{L}$ of caustic soda and $2.5 \mathrm{~mL} / \mathrm{L}$ of wetting agent (Lavotan TBU).

The figure 1 shows a sketch of the experimental system. It is composed of a device permitting the vertical suspension of the fabric-surface on the liquid and a lighting system. In order to measure the mass of the water, the fabric is attached to two sensitive electronic balances with the accuracy of $0,001 \mathrm{~g}$ :

1. The first balance " $\mathrm{B}_{1}$ " has the capability of recording the weight of the total raised water $(g)$ versus time (s);

2. The second balance " $\mathrm{B}_{2}$ " measures the weight of the absorbed water by the sample $(\mathrm{g})$ versus time (s).

All the experiments were done in a conditioning testchamber which allows us to control the temperature and the humidity of the samples atmosphere. Then, the tests are performed in:

1. A saturated environment (absence of evaporation): atmosphere of $(25 \pm 2)^{\circ} \mathrm{C}$ and $99 \%$ of humidity.

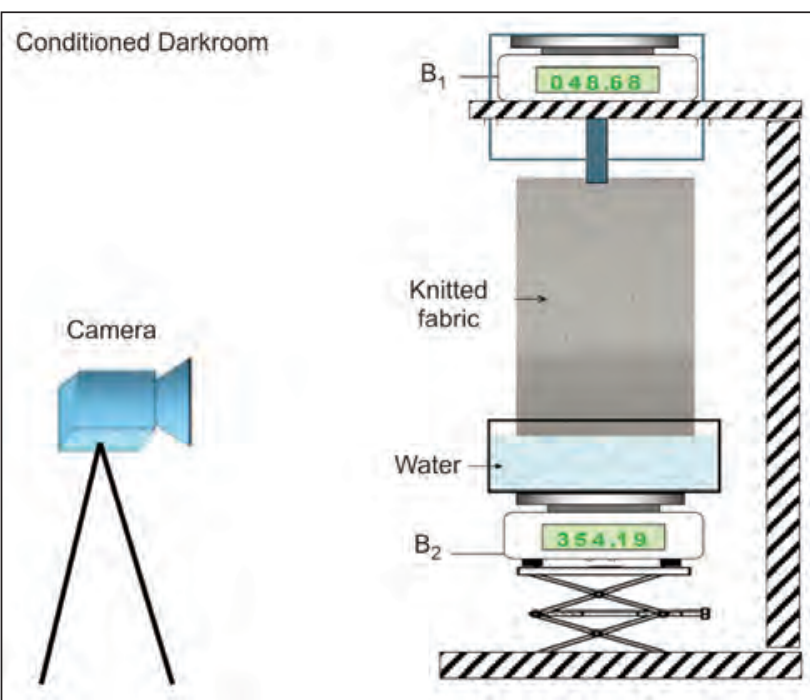

Fig. 1. Experimental device

2. An unsaturated environment: atmosphere of $(25 \pm 2)^{\circ} \mathrm{C}$ and $(65 \pm 4) \%$ humidity.

\section{RESULTS AND DISCUSSION}

\section{Experimental data}

The recording of the wicking front is done with the camera, data acquisition is controlled and processed using Matlab. Figure 2 shows a sketch of the arrangement.

The chronologies of impregnation height measurement of sample 5, in saturated and unsaturated atmospheres, are shown in figure 3.

A comparative study between the two curves allows us to confirm that wicking kinetic of water into knitted fabrics is affected by evaporation. At the first, this impact is negligible and then, for long time, it will be clearly visible.

In fact, initially, the fully dry knit is put in contact with the distilled water inducing the wetting process.

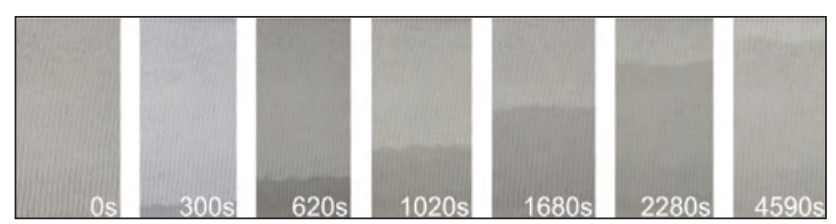

Fig. 2. Wicking of distilled water into jersey knitted fabric in saturated environment (sample 5)

\begin{tabular}{|c|c|c|c|c|c|c|c|}
\hline \multicolumn{7}{|c|}{ CHARACTERISTICS OF USED KNITTED FABRICS } \\
\hline Sample & Composition & $\begin{array}{c}\text { Knit } \\
\text { structure }\end{array}$ & $\begin{array}{c}\text { Yarn } \\
\text { spinning }\end{array}$ & $\begin{array}{c}\text { Couliering } \\
\text { depth }\end{array}$ & $\begin{array}{c}\text { Thikness } \\
(\mathbf{1 0} \mathbf{m})\end{array}$ & $\begin{array}{c}\text { Weight } \\
\left(\mathbf{g} / \mathbf{m}^{2}\right)\end{array}$ & Porosity \\
\hline 1 & $100 \%$ Cotton & Jersey & Carded & 14 & 1.99 & 359.5 & 0.883 \\
\hline 2 & $80 \%$ Cotton-20\% PES & Jersey & Carded & 14 & 2.13 & 378.1 & 0.879 \\
\hline 3 & $100 \%$ Cotton & Rib $1 \& 1$ & Carded & 14 & 2.85 & 419.2 & 0.869 \\
\hline 4 & $100 \%$ Cotton & Jersey & Open-end & 14 & 2.03 & 461.1 & 0.895 \\
\hline 5 & $100 \%$ Cotton & Jersey & Carded & 12 & 2.33 & 349.0 & 0.888 \\
\hline
\end{tabular}




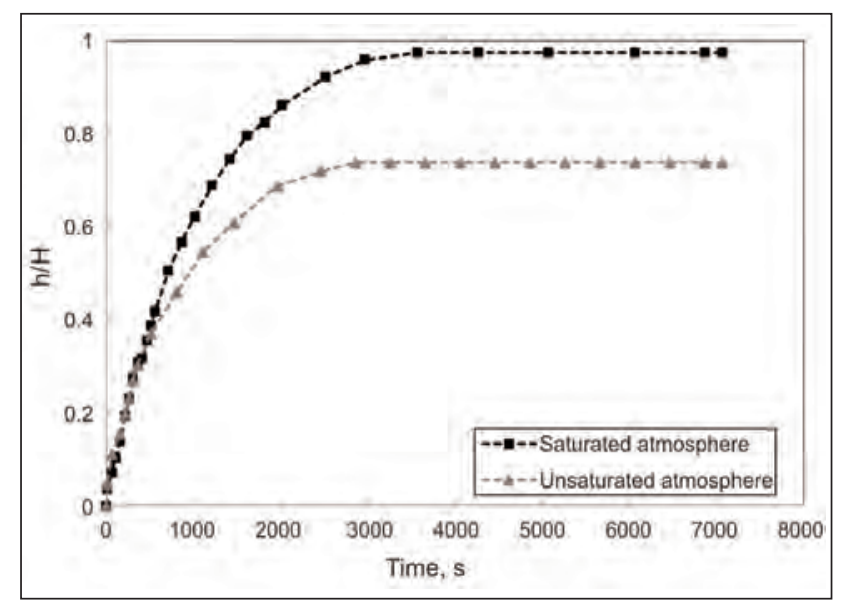

Fig. 3. Experimental data of water wicking inside sample 5 in saturated and unsaturated atmospheres

Then, the water is volatile and when the surrounding gas (air typically) is not saturated, the mass transfer evaporation can take place during the wicking process and will also possibly affect the final height reached by the liquid.

\section{Mathematical model}

In this study, in order to interpret the impact of evaporation on the equilibrium reachable height, sorption kinetic of water molecules in knitted fabrics was modelled. Then, experimental and theoretical results were compared.

\section{Differential equation of capillary progression}

When a wetting liquid encounters a porous solid medium, initially dry, which has a porosity $\varepsilon$ and a permeability $K$, in presence of evaporation, the differential equation of capillary progression was given by Fries et al. [15] as:

$$
\frac{2 \gamma \cos \theta}{R_{c}}=\rho g h+\frac{\varepsilon}{K} \mu h \frac{\mathrm{d} h}{\mathrm{~d} t}+\frac{\mu j_{e}(W+T)}{\rho K W T} h^{2}
$$

Where $\mu$ is the dynamic viscosity of the liquid, $\rho$ - the liquid density, $g$ - the gravity, $\gamma$ - the surface tension of the wetting liquid and $\theta$ - the static contact angle formed between solid and liquid, $W$ - the fabric width, $T$ - the thickness, $H$ - the height which is much greater than the width $(H>>L)$ and $j_{e}$ - the evaporation rate. $h$ is the position of the capillary rise front in the porous fabric.

This equation can be transformed as:

$$
\frac{\mathrm{d} h}{\mathrm{~d} t}=\frac{a}{h}-b-c h
$$

where: $a=\frac{2 \gamma \cos \theta}{\varepsilon \mu} \frac{K}{R_{c}}$

$$
b=\frac{\rho g}{\mu} \frac{K}{\varepsilon}
$$

and $\quad \mathrm{c}=\frac{j_{e}(W+T)}{\rho \varepsilon W T}$

\section{Maximum reachable height}

As pointed out in many researches [15, 16], different cases are distinguished from this previous equation as regards the final height of the liquid within the wick.

Solving

$$
\frac{\mathrm{d} h}{\mathrm{~d} t}=0
$$

We have many cases:

1. No evaporation occurs $(c=0)$ : in this case, the competition between gravity and capillary forces governs the maximum reachable height given by Jurin's Law [17, 18]:

$$
h_{\max 1}=\frac{a}{b}=\frac{2 \gamma \cos \theta}{\rho g R_{c}}
$$

2. Negligible gravity effects $(b=0)$ : in this case, the competition between capillary effects and evaporation sets the maximum reachable height which is given by $[15,16]$ :

$$
h_{\max 2}=\sqrt{\frac{a}{c}}
$$

3. Both gravity and evaporation must be considered which leads to $[15,16]$ :

$$
h_{\max 3}=-\frac{b}{2 c}+\sqrt{\frac{b^{2}}{4 c^{2}}+\frac{a}{c}}
$$

4. Finally, no gravity and no evaporation are affecting the capillary rise, only the viscosity restrict the maximum reachable height as is also predicted by the Lucas-Washburn equation $[1,2,7,8]$.

\section{Evaporation impact on wicking as function the} knitted fabrics structural parameters

\section{Effect of capillary radius $R_{c}$ on evaporation impact}

Using theoretical model, described previously, and FORTRAN software, we can investigate the influence of evaporation phenomenon on wicking behavior of water in knitted fabrics, especially, on the maximum reachable height. We can predict the deviations from unaffected capillary rise confirming the experimental results.

Moreover, simple and efficient way to study the impact of fabric properties on evaporation impact on wicking is to vary the capillary radius $R_{c}$ because it has direct effect on both permeability $K[19]$ and capillary pressure $P_{c}$ [20].

For sample 5 , the evolution of final maximum water impregnation heights $h_{\max 1} / H$ and $h_{\max 2} / H$ as a function of capillary radius (varying in the range $\left[10^{-4}-10^{-2}\right] \mathrm{m}$ ) are presented in figure 4 .

It can be seen that the knit would be fully saturated for capillary radius lower than about $1,49 \cdot 10^{-4} \mathrm{~m}$ for $\left(h_{\max 1} / H\right.$ ) and about $1,07 \cdot 10^{-4} \mathrm{~m}$ (for $h_{\max 2} / H$ ). Indeed, for a greater pore size, gravity intervene and limits the rise of water. As a consequence, there is always a maximum in the impregnation height when both limiting effects, i.e. evaporation and gravity are present. Therefore, saturation will never reached. 


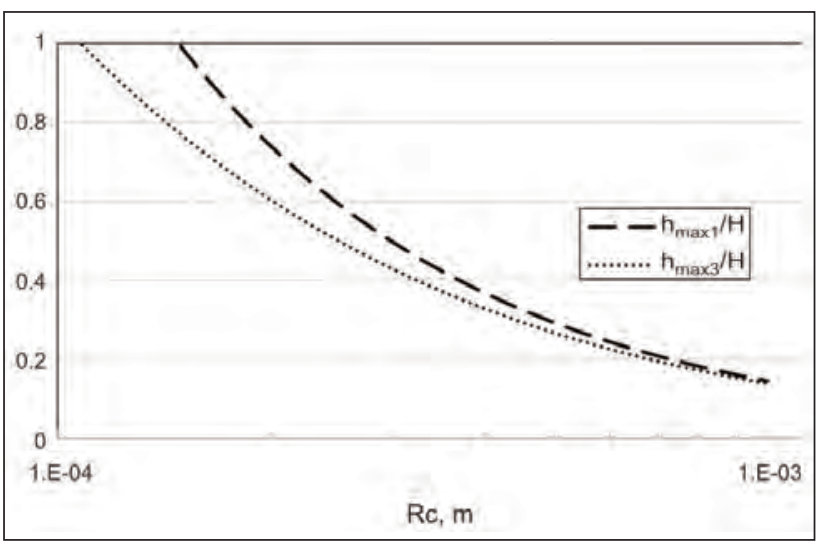

Fig. 4. Evolution of final maximum water impregnation height as a function of capillary radius of sample 5

Looking at figure 4, it can be seen also that the evaporation has an influence on the reached height by the liquid onto knitted tested fabric. In fact, for the same pore size, $h_{\max 1} / H$ values are greater than $h_{\max 2} / H$ values, which confirm the experimental results (figure 3). However, we observe that this evaporation effect is decreasing with the capillary radius. In fact, for greater capillary radius $\left(R_{c} \geq 10^{-2} \mathrm{~m}\right)$ evaporation impact on the maximum reached height becomes negligible. Nevertheless, for lower pores size, evaporation is dominant in limiting water rise.

This is explained by the fact that, for brief first moments of capillary rise, when macropore intervene, the wetted surface is limited and evaporation effect is negligible. Whereas, gradually as time passes, micropores intervene, wetted surface becomes greater and water evaporates with larger quantities.

\section{Effect of thickness on evaporation impact}

Let look at the effect of knitted fabric thickness on the evaporated height of water: Based on the theoretical model defined previously and using an algorithm developed on the FORTRAN software, we determined the evolution of maximum water impregnation height in presence of evaporation relatively to the maximum water impregnation height in absence of evaporation $\left(h_{\max 2} / h_{\max 1}\right)$ as a function of thickness. The results of this study for sample 5 are shown in figure 5 :

A curve analysis leads us to conclude that when thickness increases, $h_{\max 2}$ tends to $h_{\max 1}$, it means that the influence of evaporation becomes negligible for a sufficiently thick of fabric: In fact, the term $c$ (eq. 5), representing the evaporation effect on capillary rise and containing the evaporation flux, varies as $T^{-1}$. That's why, knitted fabric having nearly $2 \cdot 10^{-2}$ $m$ of thickness or more would be fully saturated, even in an unsaturated atmosphere.

Then, in order to compare the experimental data with the theoretical results, we will look to the evaporation rates $j_{e}\left(10^{-6} \mathrm{Kgs}^{-1} \mathrm{~m}^{-2}\right)$ determined experimentally from kinetics of evaporated mass of water molecules for each sample [21].

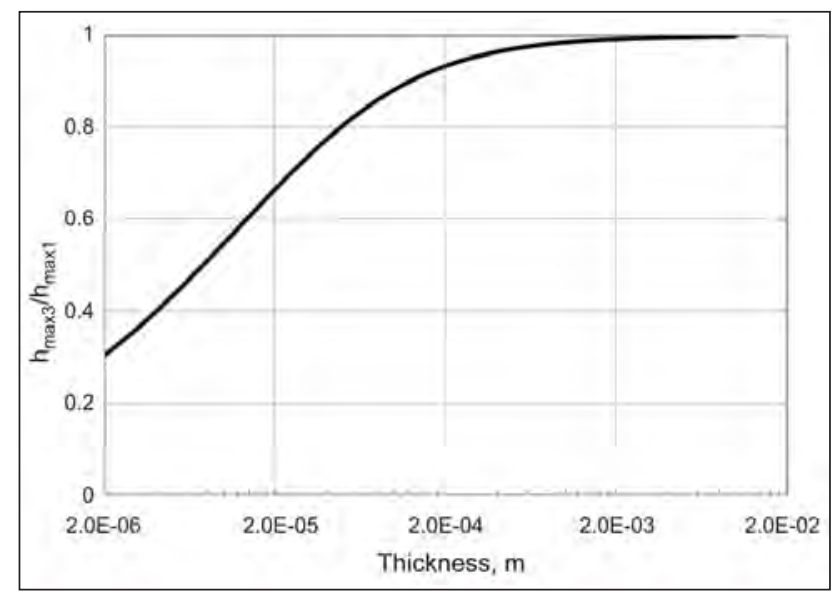

Fig. 5. Evolution of maximum water impregnation height as a function of thickness of sample 5

Table 2

\begin{tabular}{|c|c|c|c|c|c|}
\hline \multicolumn{2}{|c|}{ EFFECT OF THICKNESS ON EVAPORATION RATE } \\
\hline Sample & $\mathbf{1}$ & $\mathbf{2}$ & $\mathbf{3}$ & $\mathbf{4}$ & $\mathbf{5}$ \\
\hline Thickness $\left(\mathbf{1 0}^{-\mathbf{3}} \mathbf{m}\right)$ & 1,99 & 2,13 & 2,85 & 2,03 & 2,33 \\
$\begin{array}{c}\text { Evaporation rate } \\
j_{e}\left(10^{-6} \mathrm{Kg} / \mathrm{sm}^{2}\right)\end{array}$ & 5,665 & 7,333 & 9,333 & 15,665 & 4,666 \\
\hline
\end{tabular}

Looking at table 2, it can be seen that, for thickness values round about $2 \cdot 10^{-2} \mathrm{~m}$, evaporation rates $\left(j_{e}\right)$ values for all knitted samples are in the order of $10^{-6} \mathrm{Kg} / \mathrm{sm}^{2}$. However, for other less thick porous materials (not exceeding 200 micrometers) [16], $j_{e}$ values were found more important, they are in the order of $10^{-4} \mathrm{Kg} / \mathrm{sm}^{2}$. That can confirm the theoretical results (figure 5).

In fact, the term $c$ (eq. 5), representing the evaporation effect on capillary rise, is proportional to the evaporation rate $j_{e}$, it can confirm that the evaporation impact on the water rise kinetics decreases with the thickness of the fabrics knitted.

\section{CONCLUSION}

In this study, the water sorption onto knitted fabrics was investigated at different conditions (saturated and unsaturated atmosphere) in order to study the impact of evaporation on the maximum reachable height of capillary rise.

From the present work, mathematical model which describes the final water impregnation height evolution as a function of material structural parameters, valid for woven fabrics, was established and have been demonstrated to be satisfactory for knitted fabrics. In fact, it was demonstrated that gravity and evaporation phenomena have a significant influence on wicking behavior, especially, the maximum reachable height. Besides, it is noted that evaporation effect on water capillary rise is influenced by capillaries size and thickness which depend on structural parameters of samples. 
This mathematical model allows us to predict optimum geometrical knitted fabric parameters. Indeed, influence of evaporation becomes negligible for a sufficiently thick $\left(T \geq 2 \cdot 10^{-2} \mathrm{~m}\right)$ and greatly porous fabric $\left(R_{c} \geq 10^{-2} \mathrm{~m}\right)$.

\title{
BIBLIOGRAPHY
}

[1] Hamdaoui, M., Fayala, F., Ben Nasrallah, S. Experimental apparatus and mathematical model for determination of parameters of capillary rise in fabrics, In: J of Porous media, 2006, vol. 9, Issue 4, pp. 381-392.

[2] Hamdaoui, M., Fayala, F., Ben Nasrallah, S. Dynamics of capillary rise in yarns: Influence of fiber and liquid characteristics, In: J of Appl. Polym. Sci., 2007, vol. 104, pp. 3050-3056.

[3] Hamdaoui, M., Fayala, F., Perré, P., Ben Nasrallah, S. Experimental study of capillary rise in fabrics using an electrical resistance technique, In: AUTEX Research Journal, 2008, vol. 8, Issue 2, pp. 44-48.

[4] Fayala, F., Hamdaoui, M., Ben Nasrallah, S., Perré, P. Study of liquid distribution during capillary rise in fabrics using an electrical resistivity technique: Influence of structure and composition, In: J of porous Media, 2008, vol. 11, Issue 3, pp. 231-240.

[5] Hamdaoui, M., Achour, N.S., Ben Nasrallah, S. The influence of woven fabric structure on kinetics of water sorption, In: J EngFibers and Fabrics, 2014, vol. 9, Issue 1, pp. 101-106.

[6] Hamdaoui, M., Ben Nasrallah, S. Capillary rise kinetics on woven fabrics - Experimental and theoretical studies, In: Indian J Fibre Text Res, 2015, vol. 40, Issue 2.

[7] Perwuelz, A., Mondon, P., Cazé, C. Experimental study of capillary flow in yarns, In: Textile Res. J., 2000, vol. 70, Issue 4, pp. 333-339.

[8] Perwuelz, A., Casetta, M., Cazé, C. Liquid organisation during capillary rise in yarns - influence of yarn torsion, In: Polymer Testing, 2001, vol. 20, Issue 5, pp. 553-561.

[9] Saîhi, D., El-Achari, A., Ghenaim, A., Caze, C. Wettability of grafted poly (ethylene terephthalate) fibers, In: Polymer Test, 2002, vol. 21, issue 6, pp. 615-618.

[10] Li, Y., Luo, Z. An improved mathematical simulation of the coupled diffusion of moisture and heat in wool fabric, In: Text. Res. J., 1999, vol. 69, issue 10, pp. 760-768.

[11] Wehner, J., Miller, B., Rebenfeld, L. Dynamics of water vapour transmission through fabric barriers, In: Text. Res. J., 1988, vol. 58, issue 10, pp. 581-592.

[12] Lucas, R., In: Colloid and Polymer Science, 1918, vol. 23.

[13] Washburn, E.W., The dynamics of capillary flow, In: Phys Rev, 1921, Vol. 17, p. 273.

[14] Kawase, T., Sekoguchi, S., Fujii, T. \& Mingawa, M., Spreading of liquids in textile assemblies: Part I: Capillary spreading of liquids, In: Text Res J, 1986, vol. 56, p. 409.

[15] Fries, N., Odic, K., Conrath, M., and Dreyer, M. The effect of evaporation on the wicking of liquids into a metallic weave, In: J. Colloid Interface Sci, 2008, vol. 321, issue 1, pp. 118-129.

[16] Tissoires, S.V., Geoffroy, S., Marcoux, M., and Prat, M. Wicking in porous materials: Traditional and modern modeling Approaches, In: Chapter 8: Evaporation and wicking, pp. 202-234.

[17] Adamson. A.W. Physical Chemistry of surfaces, 1990, $5^{\text {th }}$ Wiley Intersciences, New York.

[18] Raphael, E., Capillary rise of a wetting fluid in a semi-circular groove, In: J. Phys., 1989, vol. 50, p. 485.

[19] Beyhaghi, S., Geoffroy, S., Prat, M., and Pillai, K.M. Wicking and evaporation of liquids in porous Wicks: A simple Analytical Approach to Optimization of Wick Design, In: AICHE J. 2014, vol. 60, issue 5, pp. 1930-1940

[20] De Gennes, P.G., Brochard-Wyart, F., and Quéré, D. Gouttes, bulles, perles et ondes. Ed Belin. 2002, p. 100.

[21] Achour, N.S., Hamdaoui, M., Ben Nasrallah, S. Investigation of knitted fabric properties effect on evaporation rate, In: $15^{\text {th }}$ AUTEX World Textile Conference, 2015, Bucharest, ROMANIA.

\section{Authors:}

\section{NESMA SAWSSEN ACHOUR 1,2 \\ MOHAMED HAMDAOUI ${ }^{1,3}$ \\ SASSI BEN NASRALLAH ${ }^{1}$}

Monastir University

${ }^{1}$ National School of Engineers, Department of Textile Engineering

${ }^{2}$ Laboratoire d'Etudes des Systèmes Thermiques et Energétiques (LESTE Laboratory)

${ }^{3}$ Unité de recherche en Matériaux et Procédés Textiles (M.P.Tex. Unit)

\author{
Avenue Ibn Eljazzar - 5019 \\ Monastir, Tunisia
}

Corresponding author:

NESMA SAWSSEN ACHOUR

e-mail: achour.nesmasawsen@hotmail.fr 


\title{
Influence of heater temperature and texturing speed on the physical-mechanical properties of polyamide textured yarns in false-twist texturing process
}

\author{
DOI: 10.35530/IT.068.06.1482
}

MARIJA SAVIC

PETAR STOJANOVIC
DUSAN TRAJKOVIC

MIRJANA KOSTIC
JOVAN STEPANOVIC

DIVNA MAJSTOROVIC

\section{REZUMAT - ABSTRACT}

Influența temperaturii şi vitezei de texturare asupra caracteristicilor fizico-mecanice ale firelor de poliamidă texturate prin procedeul de falsă torsiune

În prezentul articol a fost studiat efectul parametrilor tehnici și tehnologici în texturarea prin falsă torsiune asupra proprietăților fizico-mecanice ale firelor de poliamidă. Multifilamentul orientat parțial (POY) cu finețe de $22 f 07 \times 1$ dtex a fost texturat pe o mașină de texturat cu fricțiune ICBT, modelul FT 15 E3. Utilizând tuneluri lungi cu temperatură scăzută, a fost investigată influența temperaturii și a vitezei de texturare asupra caracteristicilor de ondulare, contracție și rupere a firelor. Astfel, valorile pentru raportul dintre viteza de suprafață a discurilor și viteza liniară a firelor (D/Y) de 1,9 și tensiunea din zona de texturare (întindere) de 1,305 și din zona de înfășurare de 0,954 au fost mentinute constante. Parametrii de texturare investigați afectează modificarea acestor caracteristici la grade diferite. Pentru temperaturile de 200, 210 și $220^{\circ} \mathrm{C}$, s-a constatat o corelație negativă între viteza de texturare, indicatorul de ondulare și viteza de texturare și caracteristicile de rupere, în timp ce a fost stabilită o corelație pozitivă între viteza de texturare și contracție. A fost determinat factorul de corelație între parametrii procesului de texturare și proprietățile analizate ale firelor. Pe baza rezultatelor obținute, se poate concluziona că, odată cu corelația stabilită între viteza de texturare și proprietățile investigate ale firelor, factorul de corelație crește odată cu creșterea temperaturii la $210^{\circ} \mathrm{C}$. Cu toate acestea, la temperatura de $220^{\circ} \mathrm{C}$, în general, în majoritatea cazurilor, această valoare scade. Temperatura optimă a încălzitorului este de $210^{\circ} \mathrm{C}$, luând în considerare selectarea altor valori ale parametrilor raportului dintre $D / Y$ și întindere.

Cuvinte-cheie: proprietăți fizico-mecanice, fire texturate, temperatură

\section{Influence of heater temperature and texturing speed on the physical-mechanical properties of polyamide textured yarns in false-twist texturing process}

In this paper, the effect of technical and technological parameters in false twist texturing on physical-mechanical properties of polyamide yarns was studied. Partially oriented (POY) multifilament with fineness of $22 f 07 x 1$ dtex was textured under factory conditions on a friction texturing ICBT model FT 15 E3 machine. Using low temperature long heaters the influence of heater temperature and texturing speed on crimping, shrinking and breaking characteristics of yarn was investigated. Thereby, the values for the ratio of surface speed of disks to linear yarn speed, (D/Y), of 1.9, and tension in texturing zone (stretching) of 1.305 and in winding zone of 0.954 , were kept constant. The investigated texturing parameters affect the change of these characteristics to varying degrees. For heater temperatures of 200,210 and $220^{\circ} \mathrm{C}$, linear negative correlation was found between the texturing speed, indicator of crimping and texturing speed and breaking characteristics, while the positive correlation was established between the speed of texturing and shrinkage. It was determined the correlation factor between the texturing process parameters and the analysed properties of the yarn. Based on the obtained results it can be concluded that with the established correlation between the speed of texturing and the investigated properties of the yarn, the correlation factor increases with the increase in heater temperature to $210^{\circ} \mathrm{C}$. However, at the temperature of $220^{\circ} \mathrm{C}$, generally in most cases this value decreases. Therefore, in this study, the optimum temperature of the heater is $210^{\circ} \mathrm{C}$, taking into account the selection of other parameter values of the $D / Y$ ratio and stretching.

Keywords: physical-mechanical properties, textured yarns, heater temperature

\section{INTRODUCTION}

Textured yarns of high quality require a good selection and compliance of production process parameters. The effect of temperature of the heater on the properties of textured yarns has been the subject of many studies [1-8]. With the increase in heater temperature, the mechanical characteristics of the yarn before and after the twisting zone slightly decline. To achieve good crimp a high temperature of the heater is required; on the other hand, to achieve the desired strength it is necessary to lower the temperature of heaters [9-13].

The dependence of elasticity modulus on temperature for PA6.6 fibers is presented in (figure 1). Four important regions of thermal transitions are observed with polyamide PA6. 6 fibers: at about $100^{\circ} \mathrm{C}, 200^{\circ} \mathrm{C}$, $260^{\circ} \mathrm{C}$ and $300^{\circ} \mathrm{C}$. Temperature values are approximate, since the transitions are broad and the peak positions depend on the changes rates and other factors [14]. The effects at $200^{\circ} \mathrm{C}$ (a little lower for PA6), are the key factors in the production of textured yarn. 


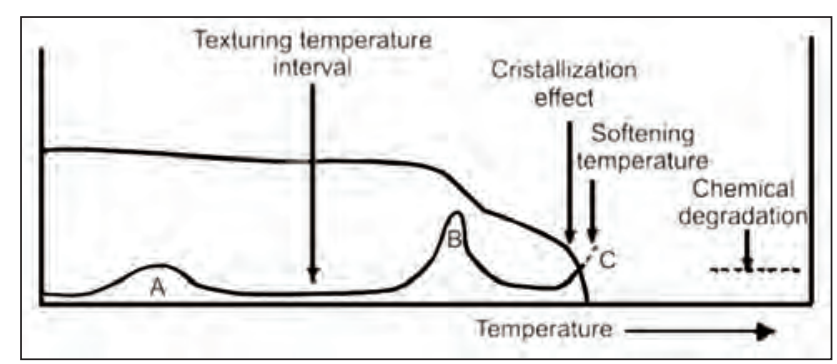

Fig. 1. Dependence of the elasticity modulus on temperature for PA 66 fibers [14]

Melting at $260^{\circ} \mathrm{C}$ (slightly lower in PA6), is an obvious change from solid to liquid state, which is studied in detail by thermal analysis. The highest transition temperature is a chemical degradation.

Depending on the speed of the yarn and the length of the heater, the retention time of the yarn in the heater is from 0.2 to 0.5 seconds, whereby there is a temperature gradient in the cross section of the filament. There are three mechanisms of heat transfer from the heater to the yarn: contact, convective and combined, but at higher texturing speeds contact heaters are applied [15-21]. The increase of the heater temperature should not be higher than $15^{\circ} \mathrm{C}$ to $20^{\circ} \mathrm{C}$ than the allowed temperature, which is from $200^{\circ} \mathrm{C}$ to $220^{\circ} \mathrm{C}$ for PA 6.6 , and from $180^{\circ} \mathrm{C}$ to $195^{\circ} \mathrm{C}$ for PA6.The empirical expression for the temperature of the yarn as a function of contact time of the yarn in the heater for conventional texturing processes (eq. 1.) was derived by Jons and Mason [22]:

$$
\ln \left[\left(T_{H}-T_{L}\right) /\left(T_{H}-T\right)\right]=\left(703 t_{n}\right) /\left(C_{p} D_{n}\right)
$$

where: $T_{H}$ is the heater temperature; $T_{L}-$ the yarn temperature at the entrance to the heater; $T$ - the local yarn temperature at the time of yarn contact with the heater $t_{n} ; C_{p}$ - the specific yarn temperature, and $D_{n}$ - the fineness of the input yarn.

\section{EXPERIMENTAL WORK}

\section{Experimental material}

PA6.6 POY multifilament yarn of fineness $22 \mathrm{f} 07 \mathrm{x} 1$ was used as the experimental material. The samples were made under production conditions on the ICBT model FT 15 E3 texturing machine (with a long heater), with a change in the technical and technological parameters: temperature in the heating zone 200, 210 and $220^{\circ} \mathrm{C}$, the speed of textured yarn removal of $600,700,800$ and $900 \mathrm{~m} / \mathrm{min}$. The values for ratio of discs surface speed and linear speed of the yarn $D / Y$ (1.9), the tension in the texturing (stretching) zone (1.305) and in winding zone (0.954) were kept constant. The disc configuration was 1-4-1 and type of discs ceramic with a diameter of $52 \mathrm{~mm}$, and $9 \mathrm{~mm}$ in thickness.

\section{Test methods}

The following standardized methods were used to test laboratory materials:

- Breaking characteristics of yarns were determined in accordance with EN ISO 2062 standard - Yarn from skeins, determination of breaking force and breaking elongation of individual strands [23];

- For the testing of crimp characteristics DIN 53840 standard procedure was used [24];

- Shrinking of textured polyamide yarn was determined in accordance with DIN 53866 [25].

Mechanical properties of textured yarns were tested on an Uster Tensorapid dynamometer, which still represents the most modern type of dynamometer. It is equipped with a system that directly records the breaking force and breaking elongation. The conditions under which the measurements were performed were as follows: with a pre-tension of $4.4 \mathrm{cN}, 20$ breaks were made. Sample length was $500 \mathrm{~mm}$, and the deformation rate was $500 \mathrm{~mm} \cdot \mathrm{min}^{-1}$.

\section{Objectives and tasks}

In the study were used the texturing process parameters that are in the upper limit of normal values used so far as a result of the intention to define the limit values of the texturing process in addition to modifying the quality of textured polyamide yarn. The study of increasing the limits of parameter $V_{i}$ and $T^{\circ} \mathrm{C}$ without too high drop in quality would be performed. The relationship between texturing process parameters (heater temperature, texturing speed) and textured yarn properties (breaking strength, breaking elongation, work of rapture, elasticity characteristics and yarn shrinking) would be established.

The values obtained should allow defining the limit values of process parameters when instability of texturing process occurs, i.e. defining the optimum settings of $V_{i}$ and $T^{\circ} \mathrm{C}$ parameters to obtain the textured PA6.6 yarn with characteristics required for a particular purpose.

\section{RESULTS AND DISCUSSION}

Experimental results show that the increase in heater temperature has a significant impact on the values of crimp and shrinking parameters, as shown in (figure 2 and 3$)$.

With the increase of the heater temperatureincreased are also the values for the crimp degree $E k(\%)$, crimp characteristics $K k(\%)$, crimp stability $K b(\%)$, and shrinking $S(\%)$. The investigation results for $E k$ (\%) for all samples are within the limits of characteristic values, in the upper part (63-65\%) except for $T 200^{\circ} \mathrm{C}$, and at higher speeds $\left(V_{i}=800\right.$ and 900 $\mathrm{m} / \mathrm{min}$ ), where the values are lower. Similar trends were observed with the crimp parameters $(K k)$ where the values in the upper range amounted to $42-46 \%$ and for lower temperatures and higher speeds about $41-42 \%$. Regarding the crimp stability, the lowest value was obtained at $T 200^{\circ} \mathrm{C}$ and $V_{i}=900 \mathrm{~m} / \mathrm{min}$, amounting to $87.896 \%$. When the texturing speed was increased, the $E k, K k$ and $K b$ values decreased. The shrinking of the textured yarn is an important characteristic of its behavior during the later heat treatment and it represents the measure of the inner structure stability and the relaxation of the inner tension in the thread. The test results showed that the shrinking values $S(\%)$ increased with the increase of 


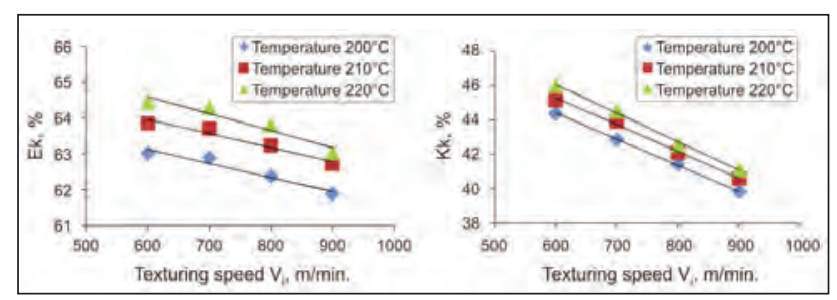

Fig. 2. The influence of heater temperature $T\left({ }^{\circ} \mathrm{C}\right)$ and the texturing speed $V_{i}(\mathrm{~m} / \mathrm{min})$, the ratio of surface speed of disc to linear speed of yarn $D / Y$ remaining constant 1.9 , on Crimp degree Ek (\%) and Crimp characteristics Kk (\%)

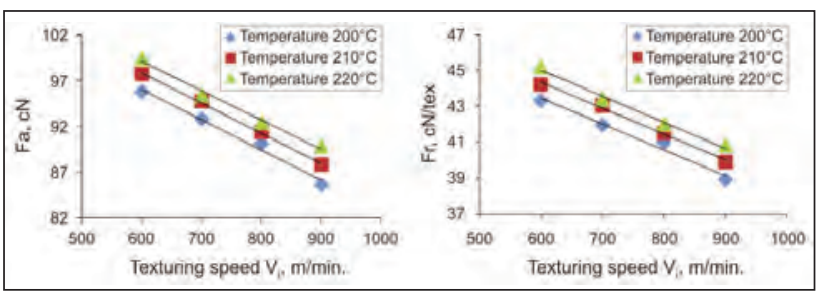

Fig. 4. The influence of the heater temperature, $T\left({ }^{\circ} \mathrm{C}\right)$ and the texturing speed, $V_{i}(\mathrm{~m} / \mathrm{min})$, the ratio of surface speed of disc to linear speed of yarn $D / Y$ remaining constant 1.9, on breaking strength $F a(\mathrm{cN})$ and, Tenacity $\operatorname{Fr}(\mathrm{cN} / \mathrm{tex})$

the texturing process parameters, $T^{\circ} \mathrm{C}$ and $V_{i} \mathrm{~m} / \mathrm{min}$, whereby a greater increase of the value $S(\%)$ was observed at $T 220^{\circ} \mathrm{C}$ for all speeds.

The correlation factor of the dependent variable $E k$ $(\%)$ and the independent variable texturing speed $V_{i}(\mathrm{~m} / \mathrm{min})$ for $T 200^{\circ} \mathrm{C}$ is $R^{2}=0.950$; it increases for $T 210^{\circ} \mathrm{C}$, and decreases for $T 220^{\circ} \mathrm{C}$. As for the remaining two crimp parameters $(K k$ and $K b)$, the correlation factor already decreases at the temperature $T 210^{\circ} \mathrm{C}$. The obtained value of the correlation factor for shrinking $S(\%)$ increases at $T 210^{\circ} \mathrm{C}$ and amounts to $R^{2}=0.972$, and then decreases at $220^{\circ} \mathrm{C}$, as is the case with $E k(\%)$. The correlation factor results for $E k(\%), K k(\%), K b(\%)$ and $S(\%)$,

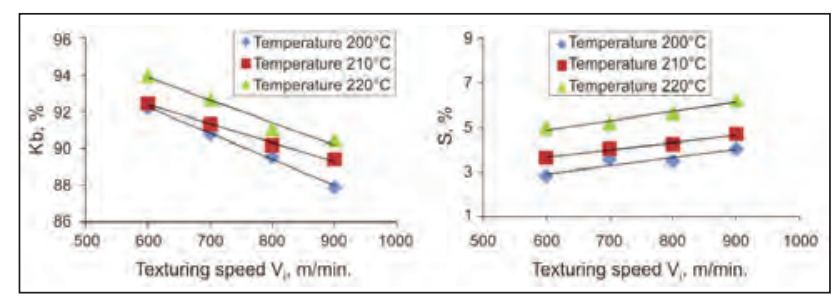

Fig. 3. The influence of heater temperature $T\left({ }^{\circ} \mathrm{C}\right)$ and the texturing speed $V_{i}(\mathrm{~m} / \mathrm{min})$, the ratio of surface speed of disc to linear speed of yarn $D / Y$ remaining constant 1.9 , on Crimp stability $K b(\%)$ and Shrinking (\%)
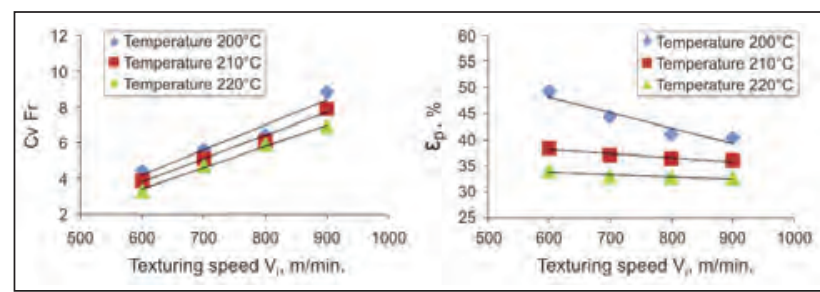

Fig. 5. The influence of the heater temperature, $T\left({ }^{\circ} \mathrm{C}\right)$ and the texturing speed, $V_{i}(\mathrm{~m} / \mathrm{min})$, the ratio of surface speed of disc to linear speed of yarn $D / Y$ remaining constant 1.9 , on Tenacity variation coefficient, $C V$ Fr and Breaking elongation, $\varepsilon_{p}(\%)$

as the dependent variables, and the texturing speed $V_{i}(\mathrm{~m} / \mathrm{min})$, as the independent variable, for the three texturing temperatures of 200,210 and $220^{\circ} \mathrm{C}$, are given in table 1 . Also, given are the linear equations describing more closely the dependence mentioned above.

Studied was the effect of variations in the heater temperature and texturing speed on the breaking strength, $\mathrm{Fa}(\mathrm{cN})$, tenacity, $\mathrm{Fr}(\mathrm{cN} / \mathrm{tex})$, variation coefficient, $C V F r$, breaking elongation, $\varepsilon_{p}(\%), C V \varepsilon_{p}$. The graphic display of the dependence is given in (figure 4, 5 and 6).

Approximate values of $\mathrm{Fa}$ and $\mathrm{Fr}$ are obtained by increasing the temperature from 200 to $220^{\circ} \mathrm{C}$ at the

LINEAR EQUATIONS AND CORRELATION FACTORS OF THE DEPENDENT VARIABLES Ek $(\%), K k(\%), K b(\%)$, $S(\%)$ AND THE INDEPENDENT VARIABLE TEXTURING SPEED $V i(\mathrm{~m} / \mathrm{min})$ FOR VARYING HEATER TEMPERATURES $T\left({ }^{\circ} \mathrm{C}\right)$ AND CONSTANT D/Y ratio, 1.9

\begin{tabular}{|c|c|c|c|}
\hline Dependent variables & Heater temperatures $\boldsymbol{T}\left({ }^{\circ} \mathbf{C}\right)$ & Linear equations & Correlation factors \\
\hline \multirow{3}{*}{ Crimp degree Ek (\%) } & 200 & $y=-0.003 x+65.49$ & $R^{2}=0.950$ \\
\cline { 2 - 4 } & 210 & $y=-0.003 x+66.28$ & $R^{2}=0.953$ \\
\cline { 2 - 4 } & 220 & $y=-0.004 x+67.42$ & $R^{2}=0.923$ \\
\hline \multirow{3}{*}{ Crimp characteristics Kk (\%) } & 200 & $y=-0.015 x+53.51$ & $R^{2}=0.999$ \\
\cline { 2 - 4 } & 210 & $y=-0.015 x+54.50$ & $R^{2}=0.996$ \\
\hline \multirow{3}{*}{ Crimp stability Kb (\%) } & 220 & $y=-0.016 x+55.96$ & $R^{2}=0.996$ \\
\cline { 2 - 4 } & 200 & $y=-0.014 x+100.6$ & $R^{2}=0.996$ \\
\cline { 2 - 4 } & 210 & $y=-0.010 x+98.52$ & $R^{2}=0.991$ \\
\hline \multirow{3}{*}{ Shrinking S (\%) } & 220 & $y=-0.012 x+101.0$ & $R^{2}=0.969$ \\
\cline { 2 - 4 } & 200 & $y=0.003 x+1.666$ & $R^{2}=0.838$ \\
\cline { 2 - 4 } & 210 & $y=0.004 x+2.315$ & $R^{2}=0.972$ \\
\hline
\end{tabular}




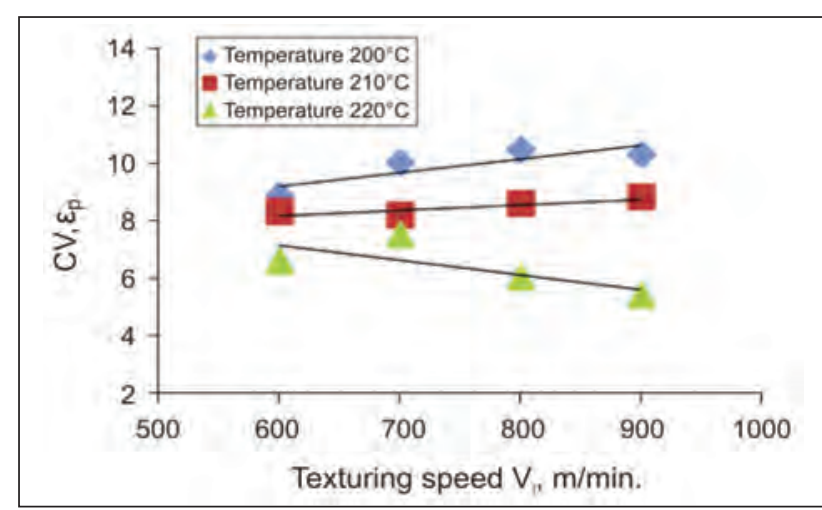

Fig. 6. The influence of the heater temperature, $T\left({ }^{\circ} \mathrm{C}\right)$ and the texturing speed, $V_{i}(\mathrm{~m} / \mathrm{min})$, the ratio of surface speed of disc to linear speed of yarn $D / Y$ remaining constant 1.9, on Breaking elongation variation coefficient, $C V \varepsilon_{p}$

speed of $800 \mathrm{~m} / \mathrm{min}$. However, at the speed $V_{i}=900$ $\mathrm{m} / \mathrm{min}$, an increase in temperature from 200 to $220^{\circ} \mathrm{C}$ leads to a significant decline in breaking strength and tenacity, which is unexpected at a lower temperature of $200^{\circ} \mathrm{C}$. The values are in the lower range (85-89 $\mathrm{cN}$; 38-41 cN/tex). This phenomenon can be explained by reduced mobility of individual molecules and insufficient time to establish new and stronger intermolecular bonds in the yarn. Up to $210^{\circ} \mathrm{C}, \mathrm{Fa}$ and $\mathrm{Fr}$ increase with the increase of heaters temperature, due to structural changes and improved orientation and arrangement of molecules in the crystalline area, while with a further increase in temperature, these changes are insignificant.

At higher speed $V_{i}=900 \mathrm{~m} / \mathrm{min}$, the heater temperature has a greater influence on the coefficient of tenacity variation, CV Fr. The lowest values of $C V F r$ were obtained at speed $V_{i}=600 \mathrm{~m} / \mathrm{min}$, a slight increase in value occurs at 700 and $800 \mathrm{~m} / \mathrm{min}$, while at $900 \mathrm{~m} / \mathrm{min}$ the increase is much higher. By increasing the temperature of the heater, at all texturing speeds, CV Fr values decline, as expected.

Approximate values for breaking elongation are obtained by increasing the heater temperature from 200 to $220^{\circ} \mathrm{C}$. At the speeds of 600 and $700 \mathrm{~m} / \mathrm{min}$, the temperature variation from 200 to $210^{\circ} \mathrm{C}$ leads to a significant decrease of $\varepsilon_{p}(\%)$ value, while at $220^{\circ} \mathrm{C}$, the decrease is slightly less. The breaking elongation, $\varepsilon_{p}(\%)$, is decreased with the increase of heater temperature, and the obtained values are consistent with the values obtained for Fa and Fr at heater temperature variation.

Reducing the temperature significantly increases the value of $C V \varepsilon_{p}$ for speeds $V_{i}$ of 800 and $900 \mathrm{~m} / \mathrm{min}$. Higher variation values were observed at $T 220^{\circ} \mathrm{C}$.

Results of correlation factors for $\mathrm{Fa}(\mathrm{cN}), \mathrm{Fr}$ (cN/tex), $C V F r, \varepsilon_{p}(\%), C V \varepsilon_{p}$, as the dependent variables and the independent variable speed of texturing, $V_{i}$ $(\mathrm{m} / \mathrm{min})$, for three texturing temperatures, 200, 210 and $220^{\circ} \mathrm{C}$, are shown in table 2 . Also, given are linear equations for these dependencies.

Based on the correlation factor, the best correlation between the parameters $V_{i}(\mathrm{~m} / \mathrm{min})$ and $T^{\circ} \mathrm{C}$ is found in:

- The breaking strength, Fa $(\mathrm{CN})$, - heater temperature of $210^{\circ} \mathrm{C}\left(R^{2}=0.998\right)$;

- The tenacity, $\mathrm{Fr}$ (cN/tex), - heater temperature of $210^{\circ} \mathrm{C}\left(R^{2}=0.995\right)$;

- Coefficient of tenacity variation, $\mathrm{Fr} C V$, - heater temperature of $220^{\circ} \mathrm{C}\left(R^{2}=0.994\right)$;

- Breaking elongation, $\varepsilon_{p}(\%)$, - heater temperature of $210^{\circ} \mathrm{C}\left(R^{2}=0.930\right)$;

- Breaking elongation variation coefficient, $C V \varepsilon_{p}-$ heater temperature of $210^{\circ} \mathrm{C}\left(R^{2}=0.793\right)$.

LINEAR EQUATIONS AND CORRELATION FACTORS OF THE DEPENDENT VARIABLES Fa (cN), Fr (cN/tex), $C V F r, \varepsilon_{p}(\%), C V \varepsilon_{p}$ AND THE INDEPENDENT VARIABLE TEXTURING SPEED $V i(\mathrm{~m} / \mathrm{min})$ FOR VARYING HEATER TEMPERATURES $T\left({ }^{\circ} \mathrm{C}\right)$ AND CONSTANT $D / Y$ ratio, 1.9

\begin{tabular}{|c|c|c|c|}
\hline Dependent variables & Heater temperatures $T\left({ }^{\circ} \mathrm{C}\right)$ & Linear equations & Correlation factors \\
\hline \multirow{3}{*}{ Breaking strength, $\mathrm{Fa}(\mathrm{cN})$} & 200 & $y=-0.033 x+115.8$ & $R^{2}=0.984$ \\
\hline & 210 & $y=-0.033 x+117.7$ & $R^{2}=0.998$ \\
\hline & 220 & $y=-0.032 x+118.2$ & $R^{2}=0.989$ \\
\hline \multirow{3}{*}{ Tenacity, Fr (cN/tex) } & 200 & $y=-0.014 x+51.98$ & $R^{2}=0.977$ \\
\hline & 210 & $y=-0.014 x+52.98$ & $R^{2}=0.995$ \\
\hline & 220 & $y=-0.014 x+53.73$ & $R^{2}=0.989$ \\
\hline \multirow{3}{*}{$\begin{array}{l}\text { Tenacityvariation coefficient } \\
\text { CV Fr }\end{array}$} & 200 & $y=0.014 x-4.2$ & $R^{2}=0.945$ \\
\hline & 210 & $y=0.013 x-4$ & $R^{2}=0.983$ \\
\hline & 220 & $y=0.012 x-3.8$ & $R^{2}=0.994$ \\
\hline \multirow{3}{*}{ Breaking elongation $\varepsilon_{p}(\%)$} & 200 & $y=-0.03 x+66.25$ & $R^{2}=0.919$ \\
\hline & 210 & $y=-0.008 x+42.96$ & $R^{2}=0.930$ \\
\hline & 220 & $y=-0.004 x+36.52$ & $R^{2}=0.814$ \\
\hline \multirow{3}{*}{$\begin{array}{l}\text { Breaking elongation variation } \\
\text { coefficient } C V \varepsilon_{p}\end{array}$} & 200 & $y=0.004 x+6.4$ & $R^{2}=0.723$ \\
\hline & 210 & $y=0.001 x+7.05$ & $R^{2}=0.793$ \\
\hline & 220 & $y=-0.005 x+10.2$ & $R^{2}=0.540$ \\
\hline
\end{tabular}




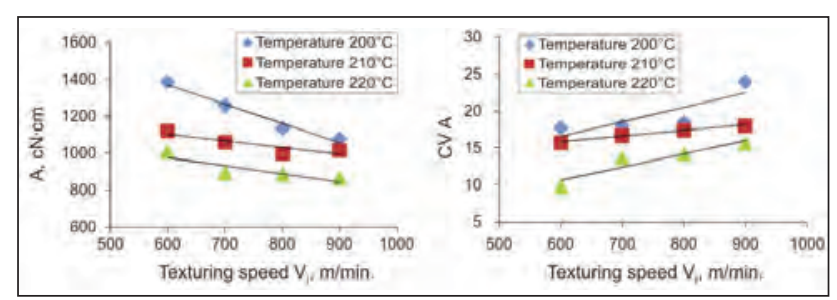

Fig. 7. The influence of the heater temperature, $T\left({ }^{\circ} \mathrm{C}\right)$ and the texturing speed, $V_{i}(\mathrm{~m} / \mathrm{min})$, the ratio of surface speed of disc to linear speed of yarn $D / Y$ remaining constant 1.9, on Work of rapture, $A(\mathrm{cN} \cdot \mathrm{cm})$ and Work of rapture variation coefficient, $C V A$

The work of rapture, which represents the area covered by the curve $F-\varepsilon_{p}$, integrates the effects of individual texturing process parameters on the breaking force and the breaking elongation. For lower speeds the obtained values of the work of rapture were higher, while they became lower with the increase of the speed, as shown in (figure 7). For $V_{i}$ of $600 \mathrm{~m} / \mathrm{min}$ it was $1007-1387 \mathrm{cN} \cdot \mathrm{cm}$, while with higher speeds, $V_{i}$ of $800 \mathrm{~m} / \mathrm{min}$ it was $881.30-1135 \mathrm{cN} \cdot \mathrm{cm}$, and for $V_{i}$ $900 \mathrm{~m} / \mathrm{min}$ it was $862.30-1078 \mathrm{cN} \cdot \mathrm{cm}$.

Increasing the heater temperature from $200^{\circ} \mathrm{C}$ to $210^{\circ} \mathrm{C}$ has less impact at the speed of $900 \mathrm{~m} / \mathrm{min}$, and it is manifested by slight reduction of the work of rapture, while the increase to $220^{\circ} \mathrm{C}$ leads to a significant reduction. As for other texturing speeds, the temperature increase to $210^{\circ} \mathrm{C}$ has a greater influence on the decrease of work of rapture.

The increase of the heater temperature from $200^{\circ} \mathrm{C}$ to $210^{\circ} \mathrm{C}$ has the greatest influence on the work of rapture variation coefficient, $C V A$, at the speed of $900 \mathrm{~m} / \mathrm{min}$, while at other speeds these variations are insignificant (figure 7). Higher texturing speeds gave significantly higher values of $C V A$, as expected and in accordance with the obtained values for $C V F_{r}$ and $C V \varepsilon_{p}$.

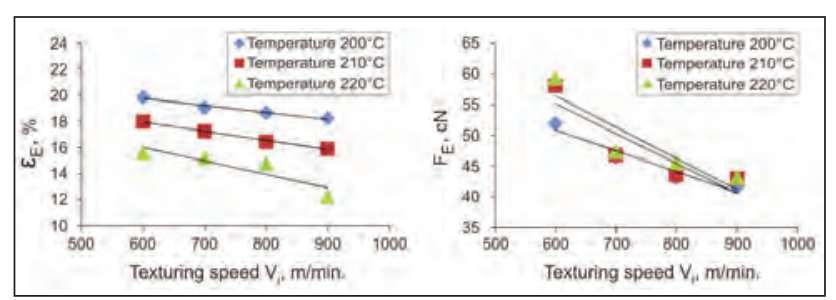

Fig. 8. The influence of the heater temperature, $T\left({ }^{\circ} \mathrm{C}\right)$ and the texturing speed, $V_{i}(\mathrm{~m} / \mathrm{min})$, the ratio of surface speed of disc to linear speed of yarn $D / Y$ remaining constant 1.9 , on Relative elongation at elasticity limit,

$\varepsilon_{E}(\%)$ and Tensile force at the elasticity limit $F_{E}(\mathrm{cN})$

The values obtained for forces and elongations at elasticity limit (figure 8) show that by increasing the texturing speed the values $F_{E}$ and $\varepsilon_{E}$ get decreased. The increase of the heater temperature has the opposite effect and to varying degrees on $F_{E}$ and $\varepsilon_{E}$, leading to a small increase in $F_{E}$, and a higher decline in $\varepsilon_{E}$. This suggests the following changes in the fibers structure: a higher degree of molecules orientation, stronger valence bonds and lower content of amorphous regions, which leads to less elongation. Based on the correlation factor, the best correlation between the parameters $V_{i}(\mathrm{~m} / \mathrm{min})$ and $T^{\circ} \mathrm{C}$ is found in:

- Work of rapture, $A(\mathrm{cN} \cdot \mathrm{cm})$ - heater temperature $T$ of $200^{\circ} \mathrm{C}\left(R^{2}=0.973\right)$;

- Work of rapture variation coefficient, CVA - heater temperature $T 210^{\circ} \mathrm{C}\left(R^{2}=0.985\right)$;

- Relative elongation at the elasticity limit $\varepsilon_{E}(\%)-$ heater temperature $T 210^{\circ} \mathrm{C}\left(R^{2}=0.992\right)$;

- Tensile force at the elasticity limit $F_{E}(\mathrm{cN})$ - heater temperature $T 200^{\circ} \mathrm{C}\left(R^{2}=0.939\right)$.

The correlation factor results for $A(\mathrm{cN} \cdot \mathrm{cm}), C V A$, $\varepsilon_{E}(\%)$, and $F_{E}(\mathrm{cN})$ as dependent variables and the speed of texturing $V_{i}(\mathrm{~m} / \mathrm{min})$ as an independent variable, at three texturing temperatures: 200, 210 and $220^{\circ} \mathrm{C}$, are presented in table 3 . Also, given are the linear equations for these dependencies.

Table 3

\begin{tabular}{|c|c|c|c|}
\hline \multicolumn{4}{|c|}{$\begin{array}{c}\text { LINEAR EQUATIONS AND CORRELATION FACTORS OF THE DEPENDENT VARIABLES } A(\mathrm{cN} \cdot \mathrm{cm}), C V A, \varepsilon_{E}(\%), \\
\text { AND } F_{E}(\mathrm{cN}) \text { AND THE INDEPENDENT VARIABLE TEXTURING SPEED } V i(\mathrm{~m} / \mathrm{min}) \text { FOR VARYING HEATER } \\
\text { TEMPERATURES } T\left({ }^{\circ} \mathrm{C}\right) \text { AND CONSTANT } D / Y \text { ratio, } 1.9\end{array}$} \\
\hline Dependent variables & Heater temperatures $T\left({ }^{\circ} \mathrm{C}\right)$ & Linear equations & Correlation factors \\
\hline \multirow{3}{*}{ Work of rapture, $A(\mathrm{cN} \cdot \mathrm{cm})$} & 200 & $y=-1.05 x+2002$ & $R^{2}=0.973$ \\
\hline & 210 & $y=-0.369 x+1325.0$ & $R^{2}=0.781$ \\
\hline & 220 & $y=-0.445 x+1245.0$ & $R^{2}=0.775$ \\
\hline \multirow{3}{*}{$\begin{array}{l}\text { Work of rapturevariation } \\
\text { coefficient, } C V A\end{array}$} & 200 & $y=0.019 x+5.05$ & $R^{2}=0.691$ \\
\hline & 210 & $y=0.007 x+11.25$ & $R^{2}=0.985$ \\
\hline & 220 & $y=0.018 x-0.3$ & $R^{2}=0.860$ \\
\hline \multirow{3}{*}{$\begin{array}{l}\text { Relative elongation at } \\
\text { the elasticity limit } \varepsilon_{E}(\%)\end{array}$} & 200 & $y=-0.005 x+23$ & $R^{2}=0.964$ \\
\hline & 210 & $y=-0.007 x+22.13$ & $R^{2}=0.992$ \\
\hline & 220 & $y=-0.010 x+22.09$ & $R^{2}=0.804$ \\
\hline \multirow{3}{*}{$\begin{array}{l}\text { Tensile force at the elasticity } \\
\text { limit } F_{E}(\mathrm{cN})\end{array}$} & 200 & $y=-0.034 x+71.26$ & $R^{2}=0.939$ \\
\hline & 210 & $y=-0.048 x+84.37$ & $R^{2}=0.798$ \\
\hline & 220 & $y=-0.050 x+86.72$ & $R^{2}=0.819$ \\
\hline
\end{tabular}




\section{CONCLUSIONS}

Analysis of the impact of heater temperature and texturing speed points to the following conclusions:

- Variations in the heater temperature show a greater impact on the crimp indices, $E k$ and $K b$ than the variations of texturing speed, while the impact on crimp characteristic, $K k$, is similar, and to a lesser extent, for both studied parameters.

- Increasing heater temperature and speed of texturing increases the shrinking of the yarns. In the range $V_{i}=850-900 \mathrm{~m} / \mathrm{min}$, at a maximum temperature of $220^{\circ} \mathrm{C}$, a greater impact on the shrinking was observed, which indicates the instability of the yarn structure. Thereby, the instability of the yarn structure, at high temperatures is explained by insufficient time for relaxation.

- Increase in the heater temperature leads to an increase in absolute force andtenacity. Above a temperature of $210^{\circ} \mathrm{C}$, this increase is slightly less than for the lower temperatures. The strength increases with increasing temperature, which can be explained by structural changes, improved orientation and arrangement of molecules in the crystalline area. Breaking elongation decreases with increasing heaters temperature.

- It was found that the mechanical characteristics: relative elongation at the elasticity limit, $\varepsilon_{E}(\%)$, tensile force at the elasticity limit, $F_{E}(\mathrm{cN})$ and the work of rapture, $A(\mathrm{cN} \cdot \mathrm{cm})$ decrease with increasing texturing speed, but $F_{E}(\mathrm{cN})$ increases with increasing heater temperature at low speed.

- Correlation factor between the speed of texturing and the investigated yarn properties increases with increasing heater temperature to $210^{\circ} \mathrm{C}$. However, at higher temperatures it decreases.
- The observed differences in the physical and mechanical characteristics of the studied samples are the result of the structural changes caused by variations in temperature and texturing speed.

As the use of textured PA6.6 yarns and requirements of products for which they will be applied determine the required quality, in this way for certain purposes the values of parameters can be adjusted allowing the influence on production economy (production increase). Such approach requires strict control of texturing process parameters and stability.

Based on the analysis of the test results, recommendations for the optimum texturing parameters can be given, which would help to achieve the best physical and mechanical characteristics of the yarn. For texturing of polyamide multifilament fineness $22 \mathrm{f} 07 \times 1$ dtex, the optimum temperature of the heater is up to $210^{\circ} \mathrm{C}$, and the texturing speed of $800 \mathrm{~m} / \mathrm{min}$; thereby the $D / Y$ ratio is 1.9 , the tension in the texturing zone (stretching) is 1.305, and in the winding zone 0.954 .

The texturing ability, as well as the process stability largely depends on the characteristics of friction aggregate, primarily on the number and configuration of disks [26-28]. The material from which the discs are made also affects the properties of the yarn, especially its more common bulk. In our case, ceramic discs allow a good transfer of twist, low wear, they have a long lifetime and are particularly used for texturing of polyamide yarn.

The research in this paper provide a certain scientific contribution in the field of obtaining textured polyamide filament yarns, in relation to the impact and interaction parameters of texturing on the physical and mechanical properties of polyamide yarn. In addition, research can serve as a basis for further improvements and rationalization of production.

\section{BIBLIOGRAPHY}

[1] Foster, P. W., Aggarwal, R.J., Lu, B.I., Gunasekera, U.S.W., Cork, C.R. A new concept in cooler design for false-twist texturing systems, In: Textile Research Journal, July 2002, vol. 72, issue 7, pp. 567-572.

[2] Karakaş, H.C., Dayioğlu, H. Influence of major false-twist texturing parameters on the structural properties of polyamide 6.6 yarn, In: Fibers \& Textiles in Eastern Europe, 2004, vol. 12, issue 2 (46), pp. 23-28.

[3] Vasanthan, N., Huang, X.X. Effect of polymer microstructure on dye diffusion in polyamide 6.6 fibers, In: Journal of Applied Polymer Science, 2003, vol. 89, issue 14, pp. 3803-3807.

[4] Gupta, V.B., Majumdar, A., Seth, K.K. Structural changes in nylon 6 yarn on heat-setting and friction-twisted texturing, In: Textile Research Journal, 1974, vol. 44, pp. 539-544.

[5] Barnes, D.S., Morris, W.J. Rates of setting in false-twist draw-texturing, Part II: The effects of heating time and heater length in the processing of nylon 6.6 yarns, In: Journal of the Textile Institute, 1980, vol. 71, issue 6, pp. 299-300.

[6] Kveder, S.M., Rijavec, T. Dynamic mechanical properties, superstructure and texturability of PA 6.6 partially oriented yarns, In: Textile Research Journal, 1994, vol. 64, issue 9, pp. 495-500.

[7] Tavanai, H., Denton, M.J., Tomka, J.G. The twist-related structure of yarns with few filaments, In: Journal of the Textile Institute, 1997, vol. 88, issue 2, pp. 107-117.

[8] Schuhmacher, H. Texturing on Short Heaters, H.ICl (Evropa) Fibres, 1992.

[9] Schmenk, B., Wulfhorst, B., Gries, T., Schedukat, N. Ensuring process stability and yarn quality in high-speed false-twist texturing, In: Chemical Fibers International, October 2002, vol. 52, pp. 348-351.

[10] Süpüren, G., Çelik, P., Özdil, N. Effect of production parameters on friction properties of textured polyester yarns. AUTEX 2009 - World Textile Conference, 26-28 May, Izmir, Turkey. 
[11] Rengasamy, R.S., Kothari, V.K., Patnaik, A. Effect of process variables and feeder yarn properties on the properties of core-and-effect and normal air-jet textured yarns, In: Textile Research Journal, 2004, vol. 74, issue 3, pp. 259-264.

[12] Kothari, V.K., Isthiaque, S.M., Ogale, V.G. Tensile properties of polyester/cotton blended yarns, In: Indian Journal of Fibre \& Textile Research, 2002, vol. 27, issue 1, p. 48.

[13] Schmenk, B., Wulfhorst, B., Gries, T., Schedukat, N. New developments for online quality control in high-speed false-twist texturing, In: Chemical Fibers International, October 2002, vol. 52, pp. 352-353.

[14] Hearle, J.W.S., Hollick, L., Wilson, D.K. Yarn Texturing Technology, Woodhead Pub: Cambridge, 2001.

[15] Wulfhorst, B., Meier, K. Investigations on a short high temperature heater, In: Chemiefasern - Textilindustrie, January/February 1993, vol. 43/95, p.40.

[16] Demir, A., Behery, H.M. Synthetic Filament Yarn Texturing Technology, Prentice Hall: New Jersey, 1997.

[17] Karakaş, H.C., Dayioğlu, H., Veit, D. Performance of polyester POY on false-twist texturing machines with high-temperature heater, In: Chemical Fibers International, 1998, vol. 48, p. 527.

[18] Yildirim, K., Altun, S., Ulcay, Y. Relationship between yarn properties and process parameters in false-twist textured yarn, In: Journal of Engineered Fibers and Fabrics, 2009, vol. 4, issue 2, pp. 26-32.

[19] Wang, Q., Jiankun Wang, J., Cheng, L. Analysis of factors to influence yarn dynamical mechanical property, In: Modern applied science, 2009, vol. 3, issue 1, p. 117.

[20] Çelik, P., Özdil, N., Süpüre, G. Experimental investigation on the static and dynamic strength of false twist textured polyester yarns, In: Industria Textilã, 2011, vol. 62, issue 1, p. 38-43.

[21] Eskin, N. Analysis of a high temperature heater in a false twist texturing process, In: Energy Conversion and Management, September 2003, vol. 44, issue 16, pp. 2531-2547.

[22] Jones, C.R., Mason, T. 9-Heat transfer in a false-twist-bulking process, In: Journal of the Textile Institute, March 1971,vol. 62, issue 3, pp. 147-165

[23] SRPS EN ISO 2062 - Pređa u namotajima, određivanje prekidne sile i prekidnog izduženja pojedinačnih niti, 2012, pp. $1-19$

[24] DIN 53840 - Determination of parameters for the crimp of textured filament yarns, november 1983, (in two parts).

[25] DIN 53866 - Testing of textiles; shrinkage of single and plied yarns, determination of shrinkage in water, 1979.

[26] Endo, T., Shintaku, S., Kinari, T. Mechanics of disk-type false twisting, Part I: Yarn path and friction force on a single disk, In: Textile Research Journal, February 2003; vol. 73, pp. 139-146.

[27] Endo, T., Shintaku, S., Kinari, T. Mechanics of disk-type false twisting, Part II: Yarn path and yarn inclination angle in a multiple-disk spindle unit, In: Textile Research Journal, 2003, vol. 73, pp. 192-199

[28] Weinsdörfer, H. Measures for increasing output in texturing, In: Chemical Fibers International, October 2001, vol. 51, pp. 370-372.

\section{Authors:}

\section{MARIJA SAVIC ${ }^{1}$}

PhD Full Professor DUSAN TRAJKOVIC ${ }^{1}$

PhD Full Professor JOVAN STEPANOVIC ${ }^{1}$

PETAR STOJANOVIC ${ }^{2}$

PhD Full Professor MIRJANA KOSTIC ${ }^{3}$

PhD Research Associate DIVNA MAJSTOROVIC 4

1 University of Niš - Faculty of Technology

Bulevar oslobođenja 124, 16000 Leskovac, Serbia

${ }^{2}$ Dunav a.d., Grocka, Serbia

Bulevar revolucije 15, 11306 Grocka, Serbia

${ }^{3}$ University of Belgrade - Faculty of Technology and Metallurgy

Department of Textile Engineering

Karnegijeva 4, 11000 Belgrade, Serbia

${ }^{4}$ Institute of General and Physical Chemistry

Studentski trg 12, 11158 Belgrade, Serbia

\section{Corresponding author:}

MARIJA SAVIC

e-mail: marisavi82@yahoo.com 


\section{Investigating the thermal comfort properties of men's jacket as single and multiple layered material}

\section{REZUMAT - ABSTRACT}

Investigarea proprietăților de confort termic ale jachetelor bărbătești din materiale mono- și multistrat

Jacheta pentru bărbați este o îmbrăcăminte realizată prin combinarea țesăturilor, a materialelor de umplere și a căptușelii. Aceste materiale au propriile lor caracteristici de confort termic. În această lucrare, sunt investigate proprietățile de confort termic ale materialelor, monostrat și multistrat din componența jachetei. Materialele monostrat au fost testste în prima configurație. Apoi materialele de umplere au fost fixate pe țesături și au fost efectuate teste cu dublu strat. În cele din urmă, țesăturile, materialul de umplutură și căptușeala au fost testate ca triplu strat. Conform rezultatelor testelor, creșterea numărului de straturi determină scăderea permeabilității la aer și la vaporii de apă și determină o creștere a rezistenței termice a materialului.

Cuvinte-cheie: jachetă bărbătească, material de umplere, căptușeală, confort termic

Investigating the thermal comfort properties of men's jacket as single and multiple layered material

Men's jacket is a garment made by combining fabrics, interlining and lining materials. These materials have their own thermal comfort features. In this work, the thermal comfort properties of the materials forming the jacket are investigated as mono layer and multilayer. The materials were tested as a single layer in first configuration. Then interlinings were fixed to fabrics and tests have been carried out as two layers. Finally, fabrics, interlinings and linings were tested as triple layer. According to the test results, the increase in the number of layers causes the decrease in air and water vapour permeability, and causes increase in the thermal resistance of the material.

Keywords: men's jacket, fabric, interlining, lining, thermal comfort

\section{INTRODUCTION}

Men's jacket is constructed of many parts, items. It is a multi-layered garment made of main fabric, linings, interlinings, shoulder pad and body canvas interlining. The first layer is the main fabric, the second layer is the interlining and the third layer is the lining.

Adhesive interlining is generally used in parts such as the front, side, upper shoulder and hemline of jackets to increase textile rigidity [1]. The interlining is produced in various types according to the fabric properties and usage place. Interlining consists of woven surface and dot type adhesive material placed on surface and used to increase fabric rigidity [1]. Number of adhesive dots in per square centimeter is located over the interlining is a factor in classifying the interlining.

The lining of a garment can commonly be used and best described as a supportive fabric [2]. The lining of the suit jacket can be categorized into two general groups: natural andsynthetic [2-3].

Consumers require from clothing not only looks but also feeling good. Comfort is getting more and more important key parameter in clothing [4]. Consumers require from clothing; lightweight, optimal thermal and humidity transport capability, air permeable fabric layers, a pattern that allows you move comfortably, no skin irritation (interaction between fabric surface structure and the skin of user, often expressed as feelings of softness, smoothness, prickliness etc.) [5]. There are many studies about the thermal comfort of properties of interlining, lining and jacket fabrics performance and comfort properties in the literature [1-3, 6-10]. But in many studies lining, interlining and fabrics are evaluated with their own performance parameters. In addition to these studies all these fabrics and materials also should be evaluated together as multilayer conditions to measure their thermophysiological comfort properties and to understand the real condition comfort of jacket.

The aim of this study was to evaluate thermal comfort properties of men's jacket fabrics and supportive materials (lining, interlining) as mono and multilayer. We have investigated and compared the air permeability, thermal resistance, thermal conductivity and relative water vapour permeability properties of jacket fabrics with different adhesive interlinings and linings.

\section{EXPERIMENTAL}

\section{Materials and methods}

In this study six types of fabrics, four types of interlinings and two types of linings commonly used in men's jacket production were tested. Tested fabrics, interlinings and linings properties were given in table 1-3. 


\begin{tabular}{|c|c|c|c|c|c|c|c|c|}
\hline \multirow{2}{*}{$\begin{array}{l}\text { Fabric } \\
\text { code }\end{array}$} & \multirow[t]{2}{*}{ Composition } & \multirow{2}{*}{$\begin{array}{c}\text { Square mass } \\
\left(\mathrm{g} / \mathrm{m}^{2}\right)\end{array}$} & \multirow{2}{*}{$\begin{array}{c}\text { Thickness } \\
(\mathrm{mm})\end{array}$} & \multirow[t]{2}{*}{ Structure } & \multicolumn{2}{|c|}{$\begin{array}{c}\text { Density } \\
\text { (thread/cm) }\end{array}$} & \multicolumn{2}{|c|}{$\begin{array}{c}\text { Yarn counts } \\
(\mathrm{Nm})\end{array}$} \\
\hline & & & & & Weft & Weft & Weft & Weft \\
\hline F1 & $100 \%$ Wool & 167.3 & 0.28 & Twill & 22 & 46 & 25 & 22 \\
\hline F2 & $100 \%$ Wool & 134.4 & 0.27 & Twill-Plain & 22 & 26 & 31 & 28 \\
\hline F3 & $100 \%$ Wool & 160.3 & 0.28 & Twill & 36 & 48 & 20 & 23 \\
\hline F4 & $70 \%$ Wool $30 \%$ PES & 162.7 & 0.26 & Twill & 34 & 40 & 19 & 22 \\
\hline F5 & $54 \%$ PES $44 \%$ Wool $2 \%$ Lycra & 160.1 & 0.27 & Twill & 30 & 34 & 31 & 28 \\
\hline F6 & $70 \%$ Wool $30 \%$ PES & 177.1 & 0.26 & Twill & 34 & 42 & 16 & 42 \\
\hline
\end{tabular}

Table 2

\begin{tabular}{|c|c|c|c|c|c|}
\hline Interlining code & Composition & Structure & Dot material & $\begin{array}{c}\text { Dot number } \\
\left(\mathbf{d o t} / \mathbf{c m}^{2} \mathbf{)}\right.\end{array}$ & $\begin{array}{c}\text { Square mass } \\
\left(\mathbf{g} / \mathbf{m}^{\mathbf{2}}\right)\end{array}$ \\
\hline $\mathbf{I 1}$ & $100 \%$ PES & 2/2 Twill & Polyamide & 110 & 34 \\
\hline $\mathbf{I 2}$ & $100 \%$ PES & $2 / 2$ Twill & Polyamide & 66 & 53 \\
\hline I3 & $100 \%$ PES & 2/2 Twill & Polyamide & 52 & 63 \\
\hline I4 & $100 \%$ PES & 2/2 Twill & Polyamide & 52 & 83 \\
\hline
\end{tabular}

Table 3

\begin{tabular}{|c|c|c|c|c|}
\hline $\begin{array}{c}\text { Lining } \\
\text { code }\end{array}$ & Composition & Thickness & Structure & $\begin{array}{c}\text { Square } \\
\text { mass } \\
\left(\mathbf{g} / \mathbf{m}^{2} \mathbf{)}\right.\end{array}$ \\
\hline L1 & $100 \%$ Acetate & 0.14 & Twill & 120 \\
\hline L2 & $100 \%$ Acetate & 0.16 & Sateen & 142 \\
\hline
\end{tabular}

The following tests were performed as mono and multilayer configuration of samples: air permeability, thermal resistance, thermal conductivity and relative water vapour permeability.

Tests were carried out in three different layer configurations as figure 1. First configuration consists of only one layer (fabric). Second configuration consists of two layers (fabric+interlining). Interlinings were fixed to the fabrics in application conditions of 2 bar Pressure, 15 seconds, and temperature of $135^{\circ} \mathrm{C}$ to create two-layer configuration in jacket production. Third configuration occurs by adding the lining fabrics on two-layer configuration (fabric+interlining+lining). The samples were obtained by cutting from different parts of the fabrics.

Air permeability tests of the fabrics were carried out with Prowhite Air Permeability Tester according to

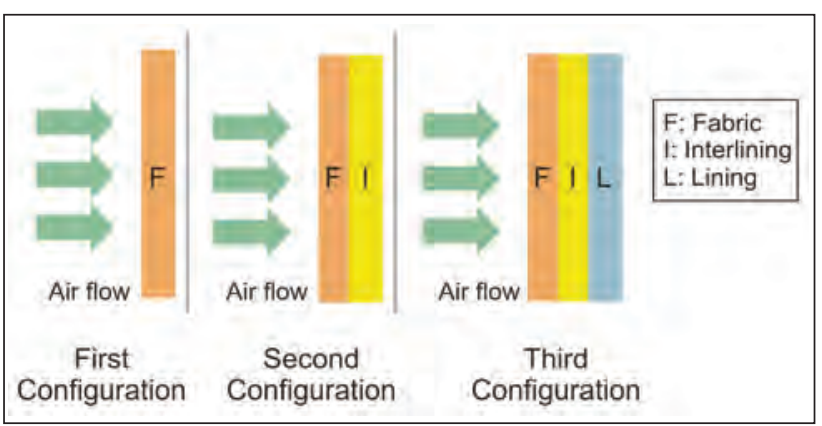

Fig. 1. Three layered composition of the men's jacket
EN ISO 9237 standard, pressure of $100 \mathrm{~Pa}$, sample area of $20 \mathrm{~cm}^{2}$ and described test conditions. Five measurements were performed for each configuration. The results of the measurements reported in table 4 and figure 2 are averages from the values.

The thermal properties were measured with the Alambeta device, which is a computer-controlled instrument for measuring the basic static and dynamic thermal characteristics of textiles. By means of the Alambeta device, besides the classical stationary fabrics' thermal properties such as thermal resistance $r$ and thermal conductivity $\lambda$, we can also assess transient thermal characteristics such as thermal diffusion $a$ and thermal absorption $b$ [11], [5]. All measurements were repeated five times.

Permetest instrument were used for relative water vapour permeability measurement. The results illustrated in figure 6 are averages from the values of three readings.

\section{RESULTS AND DISCUSSION}

\section{Air permeability}

Air permeability is one of the most important properties of textile materials that ensure their comfort [12]. Air permeability is a vital quality in such end-use applications as sport garments, underwear products, t-shirts, socks, and others. It also determines and significantly influences the thermal comfort of the human body for the proper body temperature. Air permeability is defined as the volume of air in litres, which is passed in one minute through $100 \mathrm{~cm}^{2}$ $(10 \mathrm{~cm} \times 10 \mathrm{~cm})$ of the fabric at a pressure difference of $10 \mathrm{~mm}$ head of water (TS $391 \mathrm{EN}$ ISO 9237, 1999) [13].

Table 4 and figure 2 show the air permeability results of the samples in mono and multilayer configurations. F2 has the highest air permeability among the single layer fabrics with the value of $195.2 \mathrm{~mm} / \mathrm{s}$. Air 


\begin{tabular}{|c|c|c|c|c|c|c|c|}
\hline & & & & & & & \\
\hline \multirow{6}{*}{1 Layer } & $\mathrm{F} 1$ & $\mathrm{~F} 2$ & F3 & $\mathrm{F} 4$ & F5 & F6 & \\
\hline & 90.0 & 195.2 & 130.7 & 96.8 & 144.5 & 44.5 & \\
\hline & 11 & 12 & 13 & 14 & & & \\
\hline & 1533.0 & 1612.2 & 1293.8 & 1665.0 & & & \\
\hline & L1 & L2 & & & & & \\
\hline & 96.0 & 66.4 & & & & & \\
\hline \multirow{4}{*}{2 Layer } & F-L1 & 60.3 & 134.5 & 112.0 & 71.1 & 82.7 & 38.1 \\
\hline & F1-L2 & 57.9 & 128.5 & 108,50 & 73.5 & 69.2 & 37.1 \\
\hline & F1-L3 & 55.3 & 131.8 & 118.1 & 75.2 & 58.2 & 37.0 \\
\hline & F1-L4 & 59.0 & 129.0 & 114.0 & 80.4 & 66.0 & 36.2 \\
\hline \multirow{8}{*}{3 Layer } & F1-L1-I1 & 38.2 & 65.5 & 59.3 & 44.2 & 48.6 & 29.0 \\
\hline & F1-L2-I1 & 38.0 & 65.8 & 58.9 & 46.3 & 42.3 & 28.8 \\
\hline & F1-L3-I1 & 36.6 & 65.3 & 61.5 & 48.2 & 40.2 & 28.9 \\
\hline & F1-L4-I1 & 39.0 & 63.2 & 59.8 & 48.8 & 41.1 & 27.8 \\
\hline & F1-L1-I2 & 32.3 & 53.4 & 47.1 & 36.0 & 37.9 & 26.1 \\
\hline & F1-L2-I2 & 31.5 & 48.9 & 37.4 & 37.4 & 35.9 & 25.4 \\
\hline & F1-L3-I2 & 33.6 & 49.2 & 47.2 & 37.2 & 33.7 & 25.2 \\
\hline & F1-L4-I2 & 35.4 & 53.7 & 46.5 & 40.3 & 35.0 & 26.1 \\
\hline
\end{tabular}

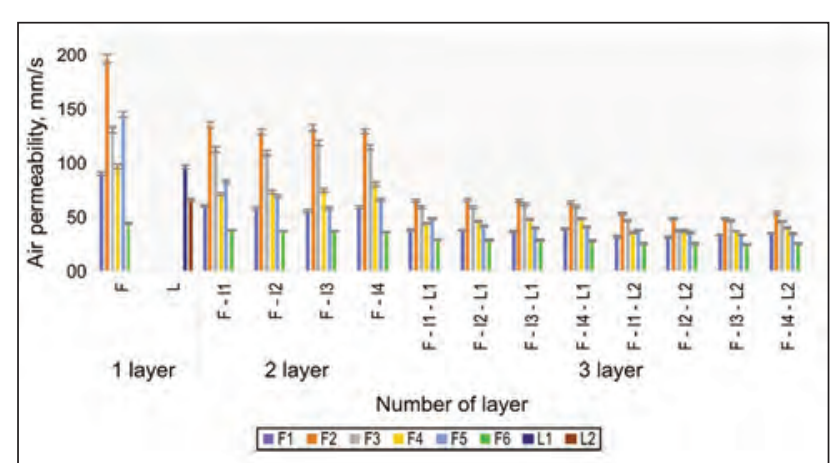

Fig. 2. Air permeability values of fabrics with mono and multilayer conditions

permeability of fabrics change due to the fabric structure, density and yarn counts and similar properties. F2 has the highest air permeability with lowest mass per square meter and density values. These values also indicate that the F2 has higher porosity values than other fabric samples. Interlinings have very high air permeability values than other tested samples. Linings results are similar to the single layer fabric results. After air permeability of single layer fabrics tests were performed, the interlining was fixed on the fabric and samples tested as two layers. The air permeability of fabrics decreases dramatically when the number of layers increases. The maximum reduction in air permeability values was $54.3 \%$ on average for F5-coded fabrics, with a minimum reduction of $17.2 \%$ for F3-coded fabrics.

After the two-layer tests performed with the samples, a triple layer was obtained by adding lining on these two layers and tests were performed as three layers. The maximum reduction in the configuration formed by L1 and L2 linings is on F5 fabric with an average of $72 \%$ and $76 \%$, with a minimum reduction of $37 \%-$
$41 \%$ in F6 fabric. Lining fabrics have two different weaving structures. The decrease in air permeability is due to the increase in the number of layers and the decrease in porosity. The intersection of weft and warp threads in each layer reduces the pores. In addition, interlinings are bonded to the fabric via adhesive dots and the dots on the interlining are closing the pores of the fabrics by melting during adhesion to the fabric. Due to this, air loses its energy due to the air passing through the second layer or the third layer, and the total air permeability drops.

\section{Thermal resistance}

Thermal resistance of fabrics is a primary determinant of body heat loss in cold environments. In hot environments or at high activity levels, evaporation of sweat becomes an important avenue of body heat loss and fabrics must allow water vapor to escape in time to maintain the relative humidity between the skin [14]. Thermal resistance is a measure of the body's ability to prevent heat from flowing through it. Under a certain condition of climate, if the thermal resistance of clothing is small, the heat energy will gradually reduce with a sense of coolness. Thermal resistance $R_{c t}$ depends on fabric thickness $(h)$ and thermal conductivity $(\lambda)$ as illustrated in equation 1 [15].

$$
R_{c t}=h / \lambda \quad\left(\mathrm{m}^{2} \mathrm{KW}\right)
$$

Figure 3 shows the average results of the thermal resistance for the tested mono and multilayer fabrics. The highest thermal resistance was obtained for the fabric sample F4 and F5 (F-I4-L2) in three-layer configuration with the value of $0.0170 \mathrm{~m}^{2} \mathrm{KW}$ in threelayer configuration. There is a high correlation with thermal resistance and thickness as shown in figure 4. 


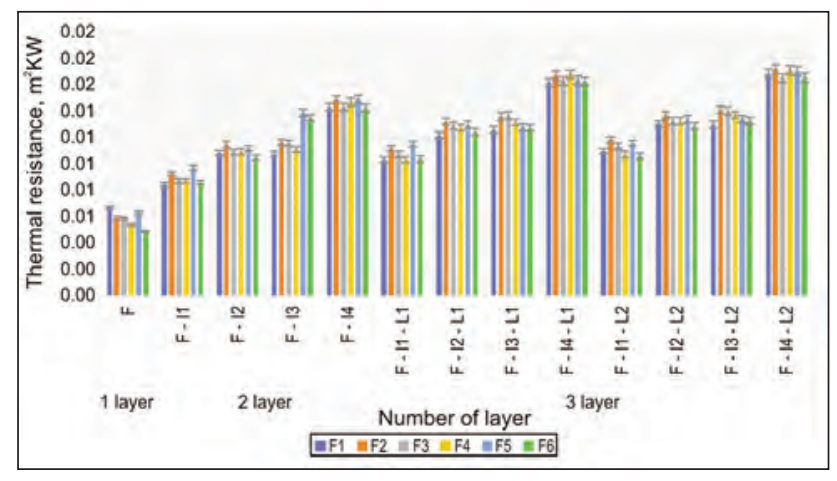

Fig. 3. Thermal resistance of the multilayer fabrics in jacket

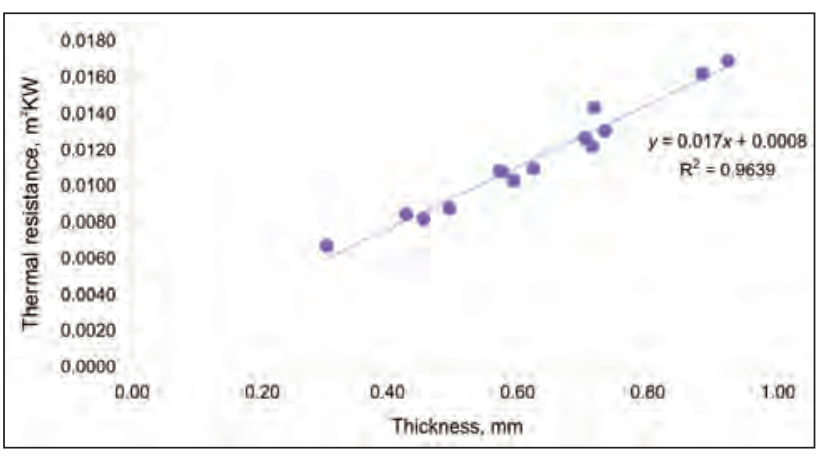

Fig. 4. Correlation between thermal resistance and material thickness

Increasing the number of layers (fabric, interlining, lining) in jacket production increases the thickness of the material, which increases the insulating property of the material. When the differences between the interlining types are examined, it is observed that the thermal resistance increases more as the interlining weight increases. It is observed averagely $54 \%$ increase in 11 interlining type and $152 \%$ increase in 14 interlining type for all fabric samples. There is not a significant difference in lining types thickness due this the effect of lining types on the thermal resistance are similar. It is observed averagely $107 \%$ increase in thermal resistance when lining used in jacket production in third layer.

\section{Thermal conductivity}

Thermal conductivity coefficient $\lambda$ presents the amount of heat, which passes from $1 \mathrm{~m}^{2}$ area of material through the distance $1 \mathrm{~m}$ within $1 \mathrm{~s}$ and create the temperature difference $1 \mathrm{~K}[15,16]$.

The thermal conductivity for the tested multilayer fabrics are presented in figure 5 and mean values of the samples have similar level. Three layered samples thermal conductivity values averagely $\% 18$ higher than one layer fabric samples values. The differences observed result from the differences of the fabric's mass per square meter. Also, the differences occur of the fabric composition and structure.

\section{Relative water vapour permeability}

The water vapour permeability of a fabric plays an important role in clothing performance. The water vapor permeability indicates the quantity of water

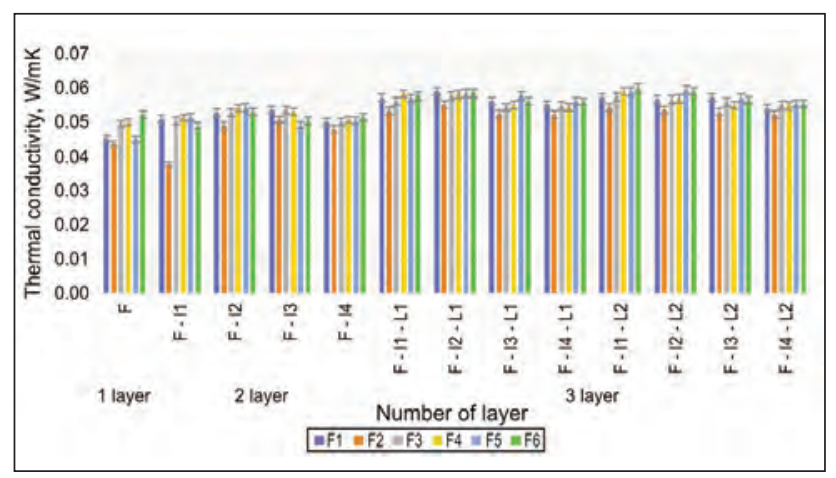

Fig. 5. Thermal conductivity of the multilayer fabrics in jacket

vapor that has been moved through a unit area of the fabric in a certain point in time as a result of the pressure gradient between the two sides of the sample [17]. Water vapor permeability is the ability to transmit vapor from the body. Relative water vapor permeability is given by the relationship:

$$
q[\%]=100 \times \frac{q_{s}}{q_{0}}
$$

where $q_{s}$ is the heat flow value with a sample $\left(\mathrm{W} / \mathrm{m}^{2}\right)$ and $q_{0}$ - the heat flow value without sample $\left(\mathrm{W} / \mathrm{m}^{2}\right)$ [15].

The results of relative water vapour permeability of samples are presented in figure 6. RWVP rates are similar for the samples and RWVP of the samples is decreases by adding layers. When the differences between the types of interlining used as the second layer are examined, the type 14 interlining is the type in which the greatest decrease is experienced. The

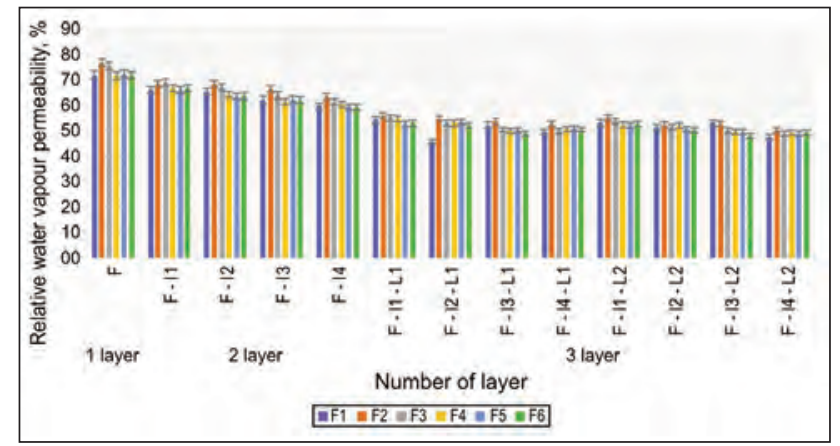

Fig. 6. Relative water vapour permeability of the multilayer fabrics in jacket

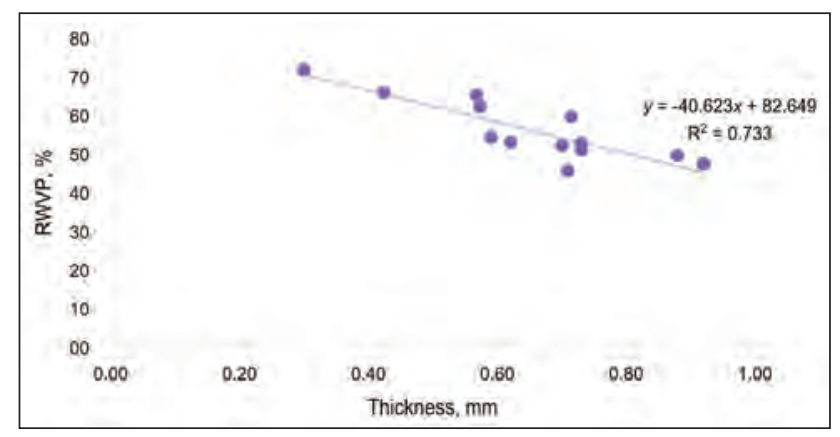

Fig. 7. Correlation between relative water vapour permeability and material thickness 
lining types in the third layer caused a decrease in relative water vapour permeability values close to each other. Figure 7 shows the correlation of thickness and relative water vapour permeability.

\section{CONCLUSIONS}

In this study, thermal comfort properties such as air permeability, thermal resistance, thermal conductivity and relative water vapour permeability have been tested to understand how these layers are going through the cumulative perception of clothing comfort. Based on the results the following conclusions are drawn:

A dramatic decrease in the air permeability values was observed according to the test results. The decrease in air permeability is due to the increase in the number of layers and the decrease in porosity. It has been observed that air permeability values have been reduced by $60 \%$ on average compared to the average of three-layer configuration air permeability results.

As the thickness increased, thermal resistance increased. Increasing the number of layers (fabric, interlining, lining) in men's jacket production increases the thickness of the material, which increases the insulating property of the material. It has been observed that thermal resistance of three-layered configuration has been increased by $49 \%$ on average compared to the average of single layer fabric thermal resistance results. The thermal conductivity for the tested mono and multilayer fabrics has similar mean values of the samples.

Relative Water Vapour Permeability rates are similar for the samples has been decreased by adding layers. Relative water vapour permeability values have been decreased by $29 \%$ on average compared to the average of three-layer configuration RWVP results.

As a result, when we look at the results of the comfort properties of the three-layered fabrics, it has been seen that the results of $100 \%$ woollen fabrics and polyester blended fabrics are close to each other. This indicates that materials with different thermal comfort properties have closer thermal comfort properties as the number of layers increases.

Lowering the number of layers in men's jacket design to regions with hot climatic conditions plays an important role in maintaining the comfort characteristics of the material.

Our next study is to test clothing comfort of a men's jacket produced in a single layer with a conventional jacket (multi-layered) with sensors and subjectively.

\section{ACKNOWLEDGEMENTS}

This research is financially supported by BAP Project (no. 2016-32), funded by Mimar Sinan Fine Arts University, Turkey.

\section{BIBLIOGRAPHY}

[1] Kim, K., Sugiyama, C. and Takatera, M. Relationship between jacket comfort and stiffness of adhesive interlining, In: Int. J. Affect. Eng., vol. 14, no. 3, pp. 137-142, 2015.

[2] Islam, M.T., Rashid, M.R. and Rana, M.R.I. Influence of different chemical treatments on the properties of PC fabric used as lining, In: Int. J. Cloth. Sci. Technol., vol. 28, no. 6, pp. 726-735, Nov. 2016.

[3] Abd El-Hady, R. A. A. A. E.-B. R.A.M. Performance characteristics of warp knitted lining fabrics used for sportswear, In: Life Sci. J., vol. 12, no. 3, pp. 98-104, 2015.

[4] Li, Y. The science of clothing comfort, In: Text. Prog., vol. 31, no. 1-2, pp. 1-135, Mar. 2001.

[5] Matusiak, M. Investigation of the thermal insulation properties of multilayer textiles, In: Fibres Text. East. Eur., vol. 14, no. 5, pp. 98-102, 2006.

[6] Kawabata, H., Obara, K., Komiyama, H. and Narumi, T. The effects of skirt lining properties on comfort and movement, In: J. Consum. Stud. Home Econ., vol. 25, no. 4, pp. 271-278, Dec. 2001.

[7] Necef, O. K. P. O. Y. Z. E. and Ondogan, Z. A study about garment collection preparation steps and quality control methods, In: Ind. Textila, vol. 64, no. 3, pp. 163-167, 2013.

[8] Kalaoglu, F. and Meric, B. Investigation of the performance of linings, In: Int. J. Cloth. Sci. Technol., vol. 17, no. 3/4, pp. 171-178, Jun. 2005.

[9] Phebe, K., Krishnaraj, K. and Chandrasekaran, B. Evaluating performance characteristics of different fusible intertinings, In: Indian J. Fibre Text. Res., vol. 39, no. December, pp. 380-385, 2014.

[10] Kim, K. and Takatera, M. Effects of dot-type adhesive and yarn float on shear stiffness of laminated fabric with interlining, In: Text. Res. J., vol. 86, no. 5, pp. 480-492, 2016.

[11] Hes, L., Boguslawska-Baczek, M. and Geraldes, M.J. Thermal comfort of bedsheets under real conditions of use, In: J. Nat. Fibers, vol. 11, no. 4, pp. 312-321, 2014.

[12] Kulichenko, A.V. Theoretical analysis, calculation, and prediction of the air permeability of textiles, In: Fibre Chem., vol. 37, no. 5, pp. 371-380, 2005.

[13] Mavruz, S. and Ogulata, R.T. Investigation of air permeability of single jersey fabrics with different relaxation states, In: J. Text. Inst., vol. 102, no. 1, pp. 57-64, Jan. 2011.

[14] Huang, J. Review of heat and water vapor transfer through multilayer fabrics, In: Text. Res. J., vol. 86, no. 3, pp. 325-336, 2016. 
[15] Ertekin, G. and Marmaralı, A. Heat, air and water vapor transfer properties of circular knitted spacer fabrics, In: Tekst. ve Konfeksiyon, vol. 21, no. 4, pp. 369-373, 2011.

[16] Hes, L. and Loghin, C. Heat, moisture and air transfer properties of selected woven fabrics in wet state, In: J. Fiber Bioeng. Informatics, vol. 2, no. 3, pp. 141-149, 2009.

[17] Kanakaraj, P., Dasaradan, B.S. and Ramachandran, R. The influence of double layer knit fabric structures on air and water vapor permeability, In: J. Text. Apparel, Technol. Manag., vol. 8, no. 3, pp. 1-9, 2013.

\section{Authors:}

\section{AKCAGUN ENGIN ${ }^{1}$ \\ YILMAZ ABDURRAHIM ${ }^{1}$ \\ ÖZ CEVIZ NURAY² \\ MAZARI ADNAN ${ }^{3}$}

${ }^{1}$ Mimar Sinan Fine Arts University, Vocational School

Cumhuriyet Dist. Silahsor St. No:71, Istanbul, Turkey

${ }^{2}$ Marmara University, Vocational School of Technical Sciences

MU Goztepe Campus, Kadikoy, 34722, Istanbul, Turkey

${ }^{3}$ Technical University of Liberec, Faculty of Textile Engineering

Department of Textile Clothing

Studentska 2, Liberec, 461 17, Czech Republic

Corresponding author:

YILMAZ ABDURRAHIM

abdurrahim.yilmaz@msgsu.edu.tr

MAZARI ADNAN

mazariadnanahmed@gmail.com

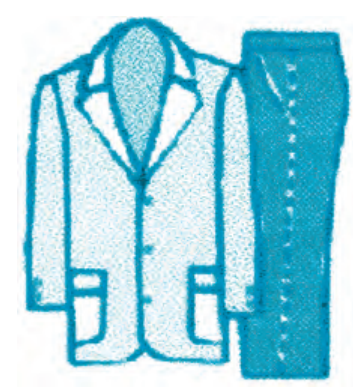




\section{Comparative dimensional statistical analyses by SEM, between unmetallized and gold-metallized $\mathrm{CuO}$-nanotreatments from textile substrates}

DOI: $10.35530 / 1 T .068 .06 .1598$

LAURENTIIU-CHRISTIAN DINCĂ

HORTENSIA-CLARA RĂDULESCU

EMILIA VISILEANU

DIONEZIE BOJIN

ALINA POPESCU

CARMEN-PYERINA GHITTULEASA

\section{REZUMAT - ABSTRACT}

Analize statistice dimensionale comparative, prin SEM, între nanotratamentele de CuO nemetalizate şi metalizate cu aur, de pe substraturi textile

În această lucrare, nanotratamentul de oxid de cupru, depus sonochimic pe substratul textil, a fost caracterizat prin microscopie electronică cu scanare (SEM). Analizele au fost efectuate în condiții de vid înalt, folosind un detector pentru electronii retrodifuzați (GAD - detector analitic de gaz). Analiza dimensională statistică a fost aplicată pe nanoparticulele tratamentului investigat. Pentru compararea rezultatelor, această caracterizare a fost utilizată în două cazuri: proba nemetalizată și proba metalizată cu aur pulverizat.

Cuvinte-cheie: SEM, metalizare cu aur, analiză statistică dimensională, nanotratament, oxid de cupru, material textil

\section{Comparative dimensional statistical analyses by SEM, between unmetallized and gold-metallized} CuO-nanotreatments from textile substrates

In this work, the copper-oxide nanotreatment, sonochemically deposited onto textile substrate, was characterized by scanning electron microscopy (SEM). The analyses were performed in high-vacuum conditions, using a detector for backscattered electrons (GAD - gaseous analytical detector). The statistical dimensional analysis was applied on the nanoparticles of the investigated treatment. Towards comparing of the results, this characterization was used in two cases: unmetallized sample and sputtering gold-metallized sample.

Keywords: SEM, gold-metallization, statistical dimensional analysis, nanotreatment, copper-oxide, textile

\section{INTRODUCTION}

The global trend is the production and the increasing using range of functional textiles. One of the ways to make them functionally is surface treatment with nanostructured deposition, which generates the textile materials with antibacterial and antifungal properties.

Like other nanoscale deposition analysis techniques, SEM contributes to providing the feedback needed to develop the surface treatment methods used to obtain these materials. Therefore, the SEM analysis methods need to provide the most accurate and complete information about the treatment of the investigated material.

Lately, a new technique for depositing metal-oxide nanoparticles has begun to show interest in applied research, including in the direction of applications in the textile industry [1]. It is a sonochemical technique based on the use of ultrasonic irradiation of the surface of the substrate to be treated, the substrate being submerged (simultaneously with irradiation) in a bath containing a liquid solution/suspension which is even the propagation medium of ultrasounds [2]. This technique of deposition is mentioned in scientific literature as more efficient and ecological than other techniques [3].

\section{GENERAL INFORMATION}

In this work a woven functionalized with $\mathrm{CuO}$ nanotreatment was analysed. This type of treatment confers the antimicrobial and the antifungal characteristics to textile material treated. The treatment technique of the investigated material was sonochemical deposition. The analysis method was scanning electron microscopy in high-vacuum medium with nitrogen-purging, using backscattered electron detector (GAD - gaseous analytical detector) and previously magnetron-sputtering gold-metallization of sample surface, followed by statistical dimensional analysis of $\mathrm{CuO}$ nanoparticles. Toward comparing the statistical results, this analysis method was applied on both unmetallized and gold-metallized samples.

The metallization with gold by magnetron-sputtering is very useful for unconductive samples (than $\mathrm{CuO}$ deposited textile), toward obtain a good resolution SEM images at tens of thousands times magnification [4].

In this paper, we compared the statistical parameters obtained by measuring of dimension (length) of 10 $\mathrm{CuO}$ nanoparticles from 10 different areas of unmetallized sample and of gold-metallized sample. The high number of dimension reads was necessary towards 
a better statistics of dimensional analysis results. This comparison between unmetallized sample and gold-metallized sample aims at the influence of thin gold-coating to the size of CuO-nanoparticles covered by this gold-layer.

The gold layer onto sample was obtained by magnetron-sputter deposition in argon atmosphere, at DC discharge current of $20 \mathrm{~mA}$, for 50 seconds.

The SEM images was acquired by FEI Quanta 200 scanning electron microscope connected to nitrogen source (200 bar bottle by 10 litres with pressure regulator).

The dimension measuring and statistical parameters calculation was performed by specialized software Scandium 5.0, after the acquiring of the SEM images. The histograms of measurement values were obtained by using MS Office Excel facilities.

\section{EXPERIMENTAL RESULTS}

\section{SEM images}

The 10 SEM images of each unmetallized and metallized sample were acquired by fixing them onto internal microscope stub using a double conductive carbon adhesive-tape.

The following table (table 1) shows 10 images captured from different areas of unmetallized sample, with the 10 dimension reads (in $\mu \mathrm{m}$ ) tagged in each image. The magnification of all images is $30000 \mathrm{X}$. The operating conditions are mentioned in bottombar of each image.

The following table (table 2) shows the 10 images captured from different areas of gold-metallized sample, with the 10 dimension reads (in $\mu \mathrm{m}$ ) tagged in each image. The magnification of all images is $30000 \mathrm{X}$. The operating conditions are mentioned in bottom-bar of each image.

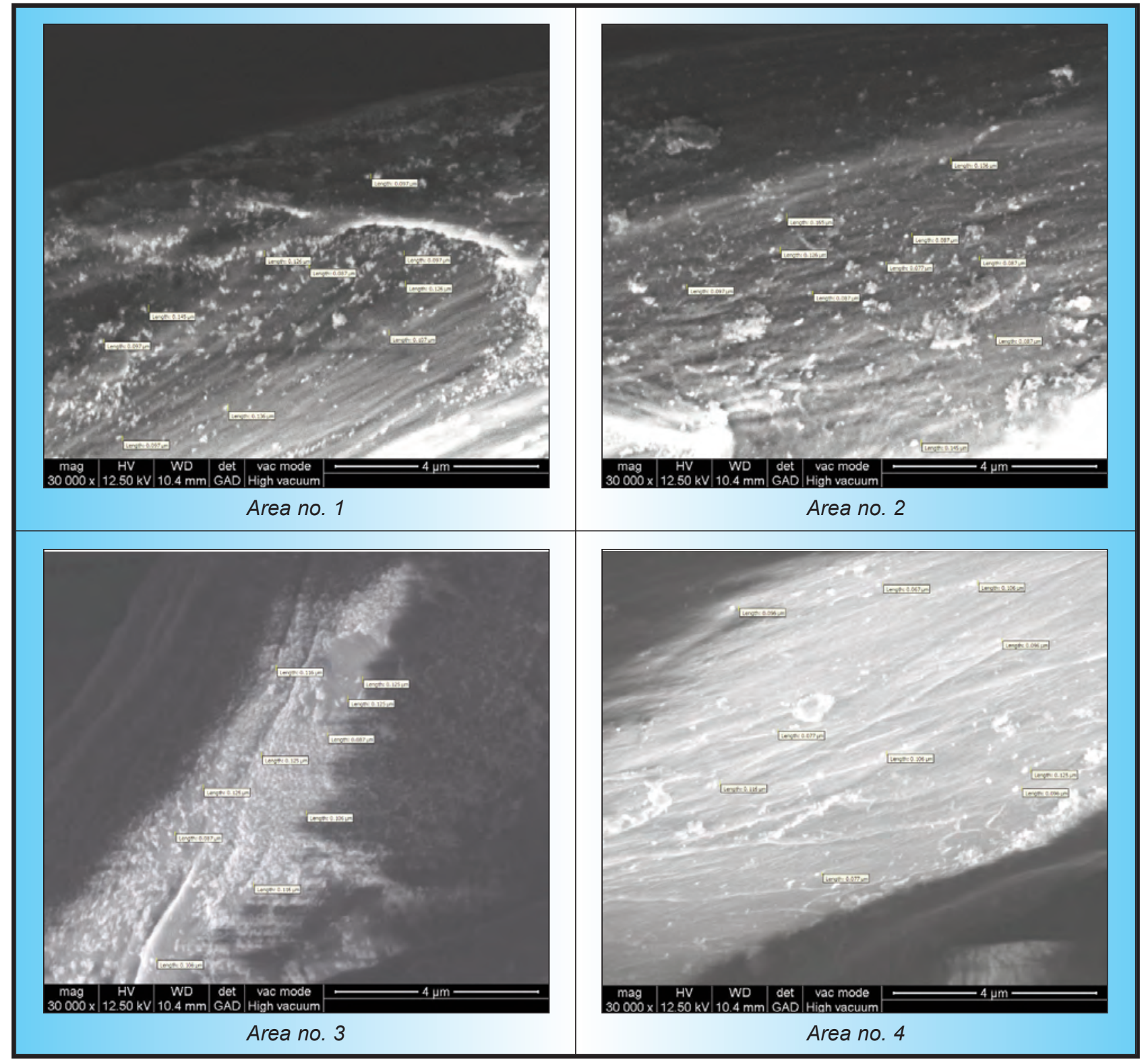




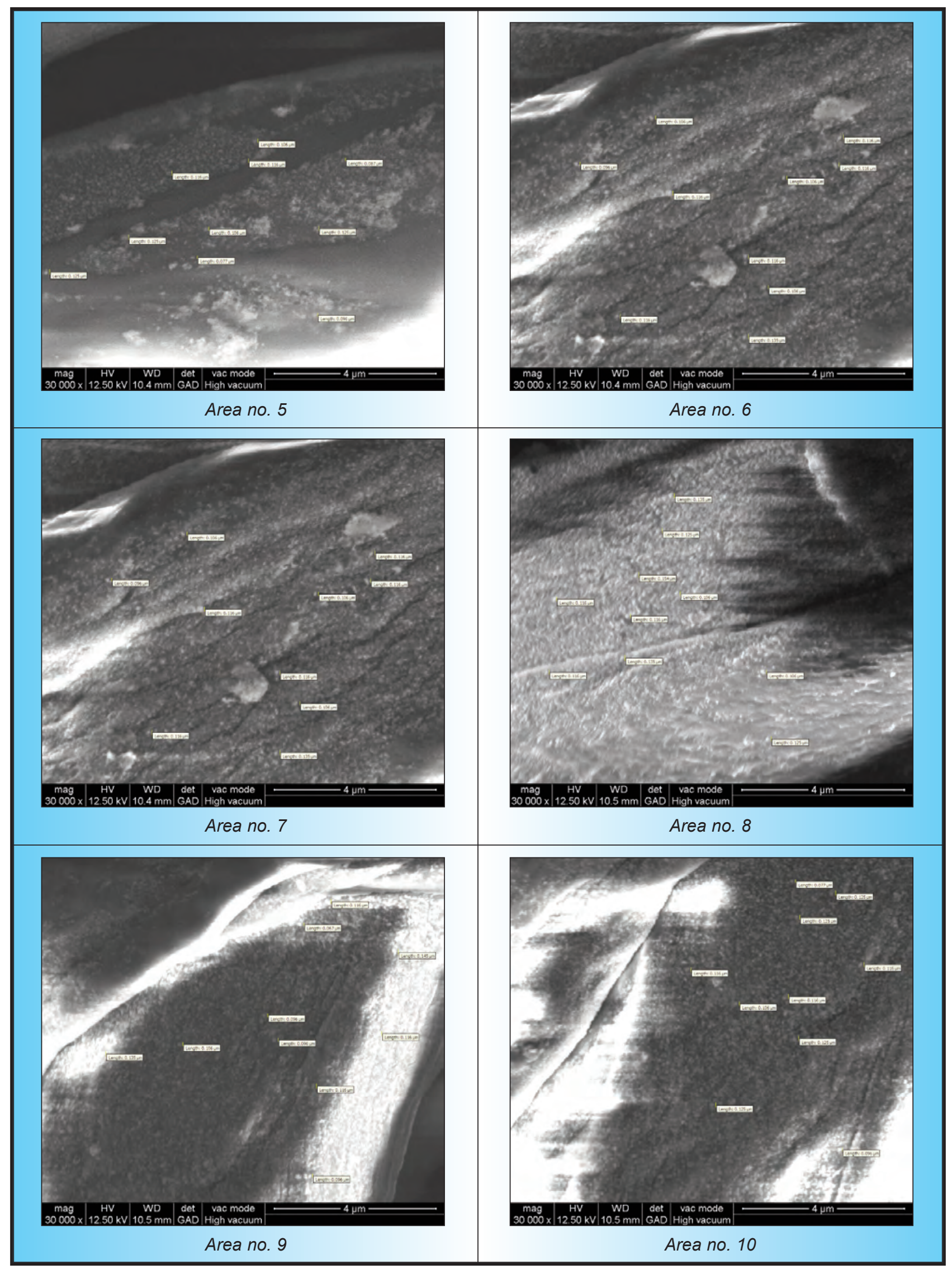

\section{Statistical histograms}

The figure 1 shows the histogram for measured sizes of $\mathrm{CuO}$-nanoparticles from the treatment of unmetallized sample.

The histogram from figure 2 represents the distribution of dimensional measurements performed on
CuO-nanoparticles from the treatment coated (metallized) with gold thin-layer.

From these two histograms, it results that the distribution of CuO-nanoparticle sizes is similar in both cases (unmetallized and metallized), namely the sizes are dominant in the $100 \div 120 \mathrm{~nm}$ interval. 
Statistical parameters

The statistical parameters (average, standard deviation, minimum value, maximum value), of the sets of measurements, were generated by the specialized soft Scandium 5.0.
The definitions of essentialy statistical parameters for a statistical collective (set) of $N$ values of measurements, noted with $\boldsymbol{d}_{\boldsymbol{i}}$ (where $i=1, \ldots, N$ ), are further presented [5]:

Table 2

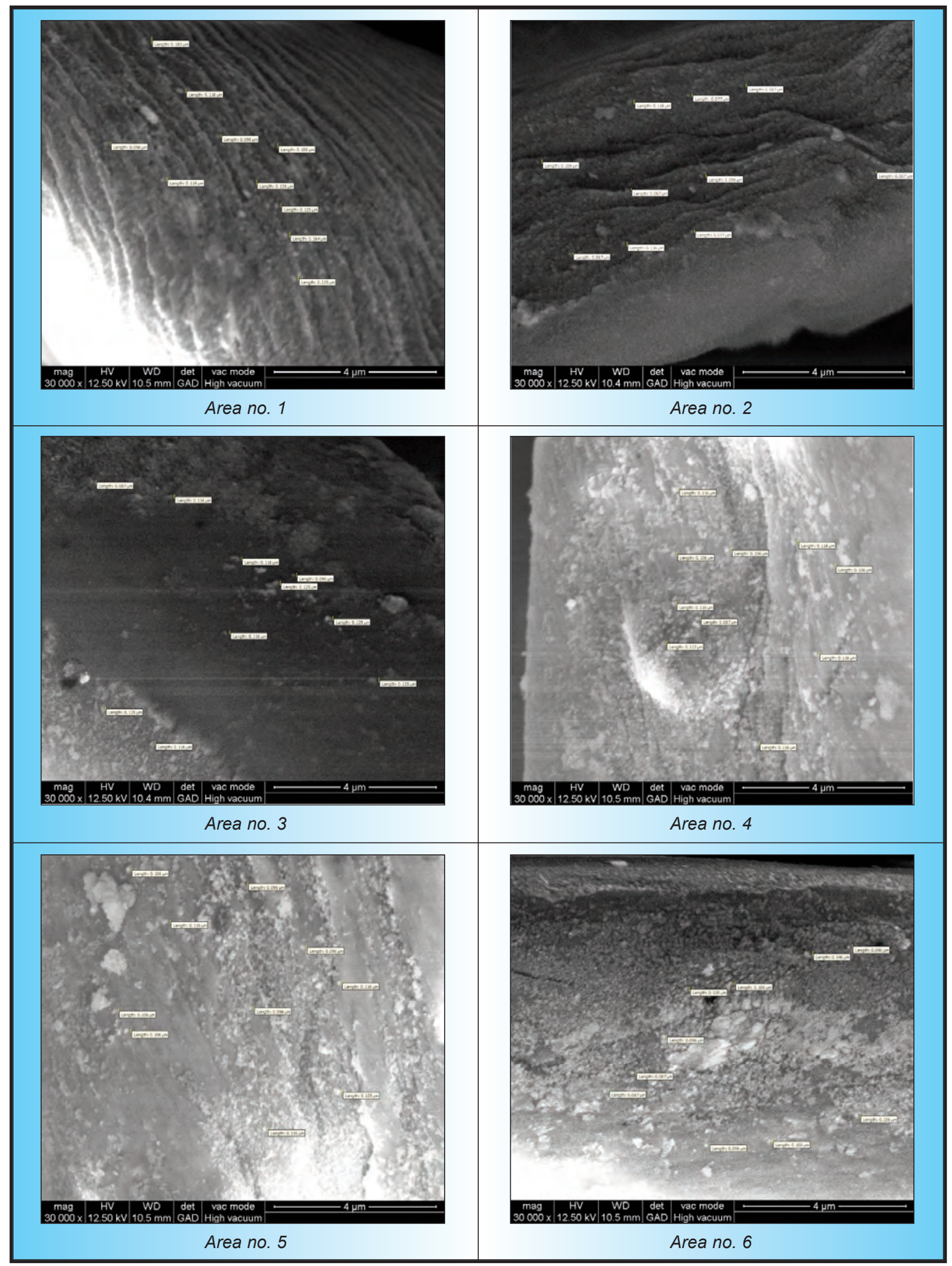




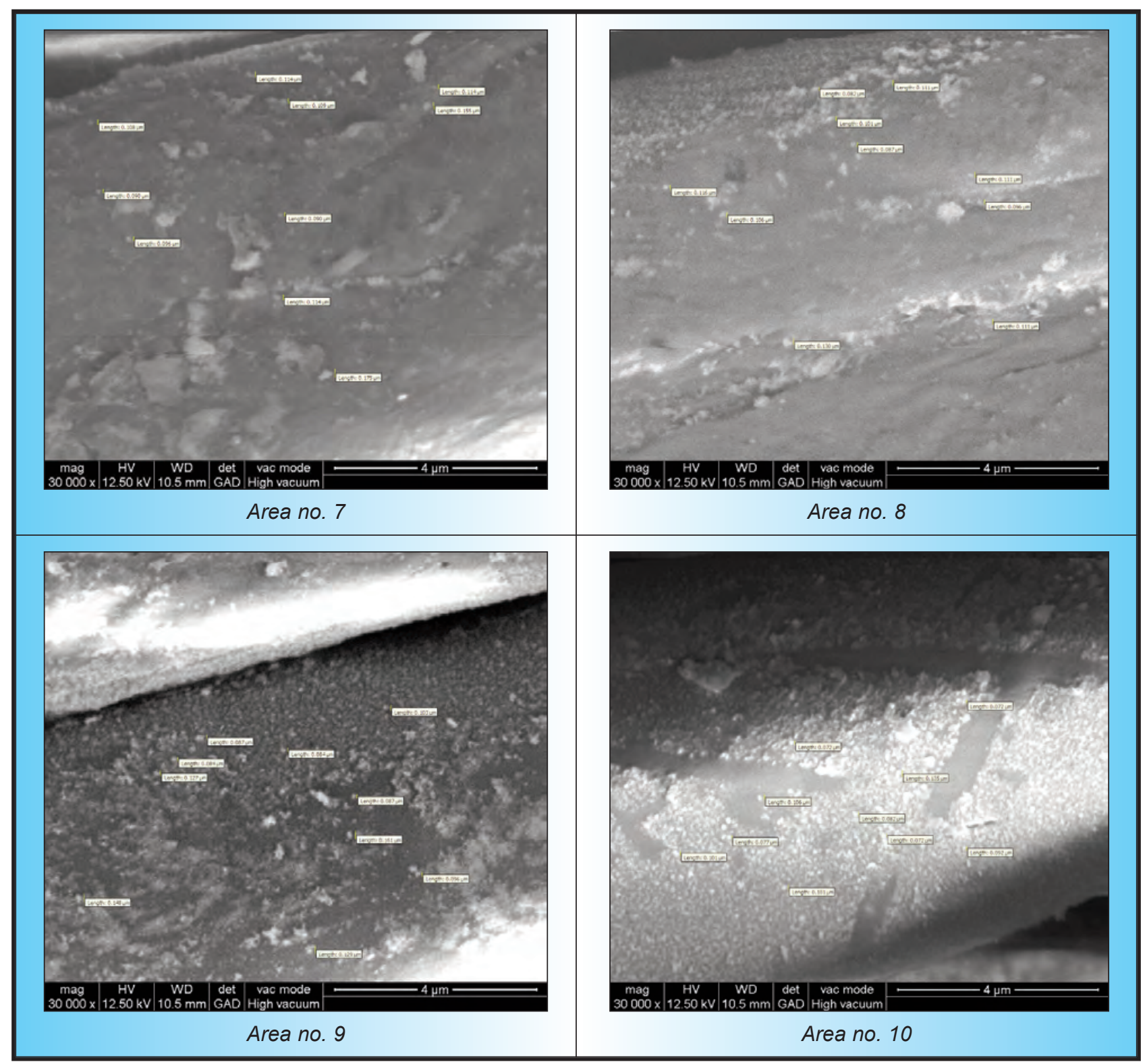

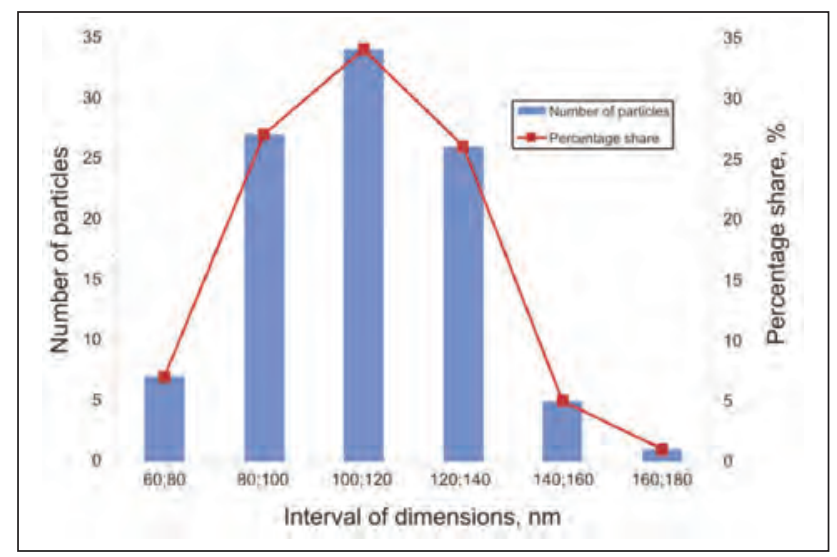

Fig. 1. Histogram of dimensional measurements for unmetallized sample

arithmetical average: $\quad \bar{d}=\frac{\sum_{i=1}^{N} d_{i}}{N}$

standard deviation: $\quad S_{d}=\frac{\sum_{i=1}^{N}\left(d_{i}-d\right)^{2}}{N-2}$

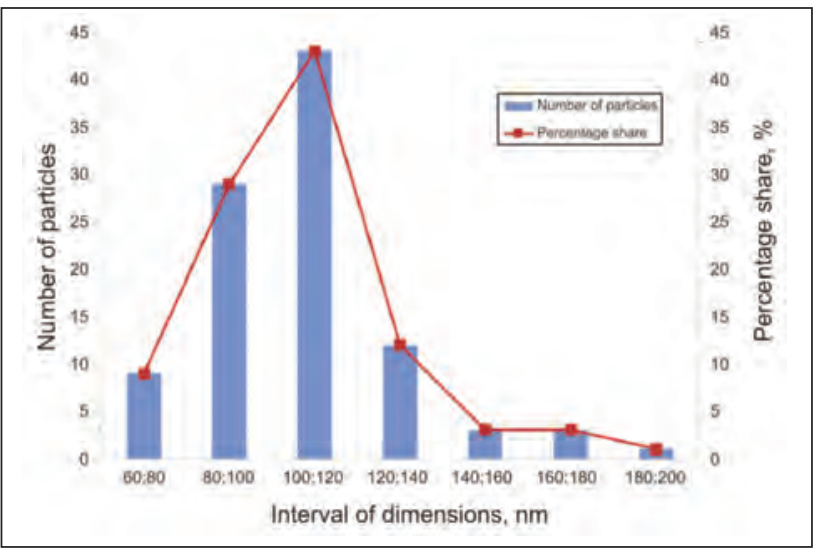

Fig. 2. Histogram of dimensional measurements for gold-metallized sample

minimum value: $\quad d_{\min }=\min \left\{d_{1}, \ldots, d_{N}\right\}$

maximum value: $\quad d_{\max }=\max \left\{d_{1}, \ldots, d_{N}\right\}$

Table 3 shows the statistical parameters calculated for the set of dimension reads in the case of unmetallized sample. 


\begin{tabular}{|c|c|}
\hline \multicolumn{2}{|c|}{$\begin{array}{c}\text { STATISTICAL PARAMETERS FOR } \\
\text { UNMETALLIZED SAMPLE }\end{array}$} \\
\hline Statistical parameters & Value \\
\hline $\begin{array}{c}\text { Number of reads } \\
\text { (measurements) }\end{array}$ & $\begin{array}{c}10 \text { images } \times 10 \text { reads }= \\
100 \text { reads }\end{array}$ \\
\hline Average & $110.6 \mathrm{~nm}$ \\
\hline Standard deviation & $19.3 \mathrm{~nm}$ \\
\hline Minimum value & $67 \mathrm{~nm}$ \\
\hline Maximum value & $165 \mathrm{~nm}$ \\
\hline
\end{tabular}

\begin{tabular}{|c|c|}
\hline \multicolumn{2}{|c|}{$\begin{array}{c}\text { STATISTICAL PARAMETERS FOR } \\
\text { METALLIZED SAMPLE }\end{array}$} \\
\hline Statistical parameters & Value \\
\hline $\begin{array}{c}\text { Number of reads } \\
\text { (measurements) }\end{array}$ & $\begin{array}{c}10 \text { images } \times 10 \text { reads }= \\
100 \text { reads }\end{array}$ \\
\hline Average & $107.7 \mathrm{~nm}$ \\
\hline Standard deviation & $22.6 \mathrm{~nm}$ \\
\hline Minimum value & $67 \mathrm{~nm}$ \\
\hline Maximum value & $193 \mathrm{~nm}$ \\
\hline
\end{tabular}

Table 4 shows the statistical parameters calculated for the set of dimension reads in the case of metallized sample.

\section{CONCLUSIONS}

The ratio between standard deviation and average (noted with $\boldsymbol{r}$ ), is proportionally with non-uniformity level of nanoparticles sizes [6].

For the sample unmetallized:

$$
r=19.3 \mathrm{~nm} / 110.6 \mathrm{~nm}=0.174=17.4 \% \text {. }
$$

For the sample gold-metallized:

$$
r=22.6 \mathrm{~nm} / 107.7 \mathrm{~nm}=0.209=20.9 \% \text {. }
$$

Based on the $r$ values, it can be said that the dimensions of the CuO-nanoparticles present a slight

non-uniformity, both for unmetallized and metallized sample.

Regarding the average, minimum and maximum values, it is confirmed that the CuO-nanoparticles from the treatment analyzed are nanometric dimensions. It is observed that the metallization of sample with thin gold layer does not influence the statistics of particles dimensions. This fact is proven by obtaining the statistic parameters very close, for both unmetallized and gold-metallized samples.

\section{ACKNOWLEDGEMENTS}

This work was performed through The Nucleus Program, with the support of National Authority of Scientific Research and Innovation (ANCSI) from Romania, within the project no. PN 16340402 .

\section{BIBLIOGRAPHY}

[1] Rădulescu, H.C., Dumitrescu, I., Visileanu, E., Dorogan, A., Vameșu, M., Mocioiu, A.M., Dincă, L., Gedanken, A., Perelshtein, I. Influences of the ultrasonic deposition of metal oxides on the physical-mechanical parameters of textile products for medical use, In: 4th TEXTEH Proceedings, Jun. $23^{\text {rd }}-24^{\text {th }} 2011$, Bucharest (Romania), pp. 198-211, ISSN 20689101.

[2] Rădulescu, H.C., Vînătoru, M., Beddow, J., Lazăr, V., Dincă, L., Joyce, E., Ghițuleasa, C., Mason, T. Conferring antimicrobial properties to fabrics by sonochemical embedding of nanoparticles, In: Industria textilă, 2014, vol. 65, no. 5, pp. 247-253, ISSN 1222-5347.

[3] Perelshtein, I., Lipovsky, A., Perkas, N., Tzanov, T., Gedanken, A. Sonochemical co-deposition of antibacterial nanoparticles and dyes on textiles, In: Beilstein J. Nanotechnol., 2016, 7, 1-8. doi:10.3762/bjnano.7.1.

[4] Scholz, J., Nocke, G., Hollstein, F., Weissbach, A. Investigations on fabrics coated with precious metals using the magnetron sputter technique with regard to their anti-microbial properties, In: Surface and Coatings Technology, 2005, vol. 192, issues 2-3, pp. 252-256.

[5] Fisker, R., Carstensen, J.M., Hansen, M.F., Bødker, F., Mørup, S. Estimation of nanoparticle size distributions by image analysis, In: Journal of Nanoparticle Research, 2000, vol. 2, issue 3, pp. 267-277.

[6] Lane, D.M., et al., Introduction to statistics, developed by Rice University, University of Houston Clear Lake, and Tufts University, online public course, http://onlinestatbook.com/

\section{Authors:}

LAURENȚIU-CHRISTIAN DINCĂ¹, HORTENSIA-CLARA RĂDULESCU1, DIONEZIE BOJIN², EMILIA VISILEANU ${ }^{1}$, ALINA POPESCU ${ }^{1}$, CARMEN-PYERINA GHIȚULEASA ${ }^{1}$

${ }^{1}$ Research-Development National Institute for Textile and Leather, 16 Lucrețiu Pătrășcanu str., Bucharest, Romania, e-mail: certex@ns.certex.ro

2'Politehnica' University of Bucharest, Center for Surface Science and Nanotechnology 313 Splaiul Independenței str., sector 6, Bucharest, Romania, e-mail: d.bojin@gmail.com

\section{Corresponding author:}




\section{Ram-air parachute design optimizations}

\section{REZUMAT - ABSTRACT}

\section{Optimizări ale proiectării parașutei de tip ram-air}

Lucrarea descrie etapele optimizate ale concepției și proiectării parașutelor de tip Ram-Air. Scopul este de a oferi un instrument pentru inginerii care lucrează în acest domeniu, care să le permită un control mai bun asupra parametrilor de proiectare și performanței parașutelor. Principalul obiectiv este îmbunătățirea timpului de dezvoltare a unui produs de la concept la prototipul real prin utilizarea de metode numerice și, acolo unde este cazul, prelucrarea asistată de calculator. Pentru a realiza acest lucru, modele numerice predeterminate sunt definite într-un cod suplimentar din cadrul software-ului CAD, care permite reglarea unor parametri principali de proiectare. Codul va purta restul procesului de proiectare până la generarea modelului și va fi adecvat lățimii rolei țesăturii. Articolul prezintă unul dintre modelele optimizate predefinite care sunt încorporate în cod.

Cuvinte-cheie: parașută de tip Ram-Air, textile tehnice, metodă numerică, modelare 3D, prototipare rapidă

\section{Ram-air parachute design optimizations}

The paper describes the optimized stages of concept and design for ram-air parachutes. The aim is to provide a tool for the engineers working in this field that allows for a better control of design parameters and performance of the parachute. The main focus is to improve the developing time for a product from concept to actual prototype by the use of numerical methods and, where applicable, computer assisted machining. To achieve this, predetermined numerical models are defined in a supplemental code within the CAD software that allows for some of the main design parameters to be adjusted. The code will carry on the rest of the design process up to the pattern generation and fit within the fabric roll width. The article details on one of the predetermined optimized models that is embedded in the code.

Keywords: ram-air parachute; technical textiles; numerical method; 3D modelling; rapid prototyping

\section{INTRODUCTION}

This type of parachute that can be controlled in flight is used in airborne activities that also use ascending and descending air currents. The launch is like parachutes, requiring different types of aircraft depending on the mission profile. The cutting-edge technologies used to produce high-performance canopies have virtually transformed a simple deceleration device into a semi-rigid wing capable of moving at $100 \mathrm{~km} / \mathrm{h}$ with high load characteristics and surprising versatility. These "rectangular" canopies have proven their usefulness to such an extent that the round canopies have almost disappeared from the sports parachute arena. The paper presents practical and practical contributions in the process of designing and manufacturing of ram-air parachutes. This exemplifies with the design of a high-versatility ram-air parachute model that can execute high-altitude launches with high-altitude opening $\mathrm{HAHO}$ (High Altitude High Opening), HALO (High Altitude Low Opening), or can be foot-launched from the ground into the wind. The design is done in a CAD system where the $3 \mathrm{D}$ model is generated and the patterns used in the parachute manufacture are done.

\section{MATERIALS AND METHODS}

For the designed ram-air parachute, the textile materials used are with the trade name Gelvenor LCN065 OL-KU for upper panels and the AS-PZ fabric for the lower panels were chosen. The profiled ribs are made of OL-KU material used also in the upper panels (table 1).

\section{RIBS GEOMETRY:}

The main parachute airfoil is a $14 \%$ high profile curvature profile with a high curvature to achieve a maximum lift even at low speeds. This is a NACA 8414 profile [1].

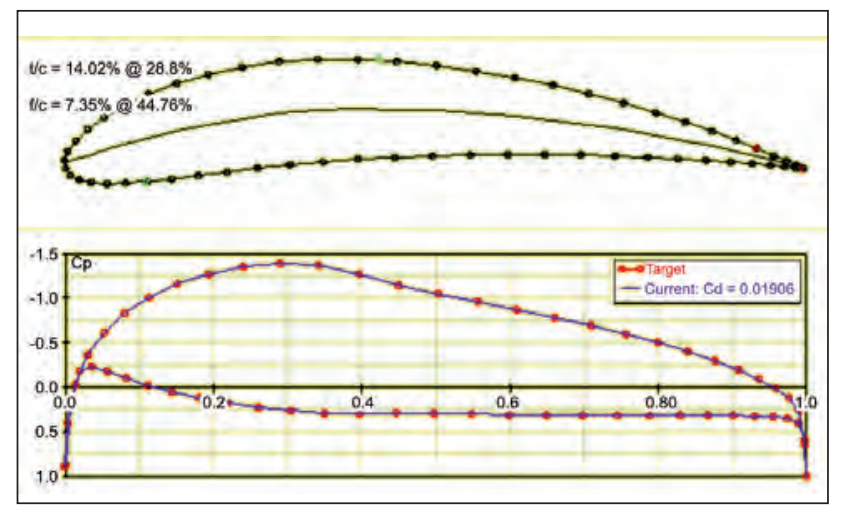

Fig. 1. Pressure coefficient $\mathrm{Cp}$ along the NACA 8414 airfoil 


\begin{tabular}{|c|c|c|c|c|}
\hline No. crt. & Characteristic & & LCN 065 OL-KU & LCN 065 AS-PZ \\
\hline 1 & Chemical composition & & PA 6.6 & PA 6.6 \\
\hline 2 & Mass, $\left(\mathrm{g} / \mathrm{m}^{2}\right)$ & & 38 & 38 \\
\hline 3 & Breaking strength, (daN) & $\begin{array}{l}\text { Warp } \\
\text { Weft }\end{array}$ & $\begin{array}{l}40 \\
40\end{array}$ & $\begin{array}{l}40 \\
40\end{array}$ \\
\hline 4 & Elongation, (\%) & $\begin{array}{l}\text { Warp } \\
\text { Weft }\end{array}$ & $\begin{array}{l}20 \\
20\end{array}$ & $\begin{array}{l}20 \\
20\end{array}$ \\
\hline 5 & Tear strength, (daN) & $\begin{array}{l}\text { Warp } \\
\text { Weft }\end{array}$ & $\begin{array}{l}4 \\
4\end{array}$ & $\begin{array}{l}4 \\
4\end{array}$ \\
\hline 6 & Air permeability, $\left(1 / \mathrm{m}^{2} \mathrm{~s}\right)$ & & 0 & 2 \\
\hline 7 & Yarn density $($ yarns $/ 10 \mathrm{~cm}$ ) & $\begin{array}{l}\text { Warp } \\
\text { Weft }\end{array}$ & $\begin{array}{l}490 \\
490\end{array}$ & $\begin{array}{l}490 \\
490\end{array}$ \\
\hline 8 & Link type & & Rip-stop simple & Rip-stop double \\
\hline 9 & Finishing treatments & & PU one side & Calendering both sides \\
\hline
\end{tabular}

Starting from the geometrical data presented in figure 1 , a, Mathcad program was developed to provide profile coordinates at any point. Two functions have been developed: Extrados $(x)$ and Intrados $(y)$ which give the upper and lower surface coordinates as follows:

- by spline interpolation on most of the profile;

- by closed formula, in the vicinity of the leading edge, where the profile is represented by a circle arc.

The parachute runs in the speed range of $25 \mathrm{~km} / \mathrm{h}$ and $50 \mathrm{~km} / \mathrm{h}$ which corresponds to the Reynolds numbers between $(1,5 \ldots 3,5) \times 10^{6}$ [2].

The following aerodynamic features are presented in the tables below:

- lift coefficient by profile attack angle, $C_{L}=f(\alpha)$;

- drag coefficient by profile attack angle, $C_{D}=f(\alpha)$; for Reynolds numbers $\operatorname{Re}=2 \times 10^{6}, \operatorname{Re}=3 \times 10^{6}$, $\operatorname{Re}=5,7 \times 10^{6}$, with and without rugosity.

Table 2 shows that the incidence angle at which the lift coefficient is zero has the value $\alpha_{C_{L}=0=-2^{\circ}}$. The lift curve slope for this profile has the value

$$
\frac{\mathrm{d} C_{L}}{\mathrm{~d} \alpha}=0,104 \frac{1}{\mathrm{grad}} \text {. }
$$

CANOPY GEOMETRY:

Planform of the wing - The wing is built using two elliptical arches:

- an ellipse on the leading edge with the semi-axes:

$$
a_{1}=1,107 \mathrm{~m} \quad b_{1}=3,305 \mathrm{~m} \text {; }
$$

- an ellipse on the trailing edge with the semi-axes:

$$
a_{2}=0,545 \mathrm{~m} \quad b_{2}=3,305 \mathrm{~m} \text {; }
$$

- chord at extremities:

$$
c_{e}=0,165 \mathrm{~m} \text {. }
$$

Synthesizing, the following geometric values were obtained for the planform of the wing.

$$
\begin{array}{lll}
C_{0}=1,652 \mathrm{~m}, & c_{e}=0,165 \mathrm{~m}, & b=6,610 \mathrm{~m}, \\
\Lambda_{1 / 4}=0^{\circ}, & S=9,670 \mathrm{~m}^{2}, & A R=4,518 .
\end{array}
$$

As a result of the aerodynamic loads, the weight and the geometric constraints imposed by the lines, the wing has an arched shape (figure 2). If it was properly designed, only stretching forces appear in the veil, and the suspensions give the shape chosen by the designer [3]. We opted for a circular arc shape with the radius of $R=4,162 \mathrm{~m}$

Geometric features of the wing:

- the half opening of the wing 'cathedral' $\Theta=45,5^{\circ}$

- projected wing span

- projected wing surface

Table 2

\begin{tabular}{|c|c|c|c|c|c|c|c|c|c|c|}
\hline $\operatorname{Re}$ & \multicolumn{9}{|c|}{$\mathrm{C}_{L}=f(\alpha)$} & \multicolumn{4}{c|}{$\mathrm{C}_{D}=f(\alpha)$} \\
\hline$\alpha\left[^{\circ}\right]$ & $3 \times 10^{6}$ & $5,7 \times 10^{6}$ & $2 \times 10^{6}$ & $3 \times 10^{6}$ & $5,7 \times 10^{6}$ & $2 \times 10^{6}$ & $2 \times 10^{6}$ & $3 \times 10^{6}$ & $5,7 \times 10^{6}$ & $5,7 \times 10^{6}$ \\
\hline-6 & $-0,424$ & $-0,424$ & $-0,440$ & $-0,430$ & $-0,430$ & $-0,413$ & 0,0082 & 0,0090 & 0,0078 & 0,01265 \\
\hline-4 & $-0,216$ & $-0,216$ & $-0,230$ & $-0,220$ & $-0,220$ & $-0,215$ & 0,0074 & 0,0078 & 0,00685 & 0,01090 \\
\hline-2 & $-0,008$ & $-0,008$ & 0 & 0 & 0 & 0 & 0,0070 & 0,0072 & 0,00648 & 0,01000 \\
\hline 0 & 0,200 & 0,200 & 0,1883 & 0,200 & 0,200 & 0,1875 & 0,0064 & 0,0068 & 0,00625 & 0,00975 \\
\hline 2 & 0,408 & 0,408 & 0,4045 & 0,408 & 0,408 & 0,402 & 0,00655 & 0,00675 & 0,0062 & 0,01000 \\
\hline 4 & 0,616 & 0,616 & 0,6107 & 0,607 & 0,610 & 0,600 & 0,00682 & 0,0070 & 0,00672 & 0,01120 \\
\hline 6 & 0,824 & 0,824 & 0,819 & 0,790 & 0,810 & 0,770 & 0,00745 & 0,0077 & 0,0080 & 0,01370 \\
\hline 8 & 1,032 & 1,032 & 1,0287 & 0,940 & 0,980 & 0,920 & 0,0107 & 0,011 & 0,0090 & 0,0170 \\
\hline 10 & 1,240 & 1,246 & 1,220 & 1,080 & 1,130 & 1,050 & 0,01375 & 0,01415 & 0,01160 & 0,02180 \\
\hline
\end{tabular}




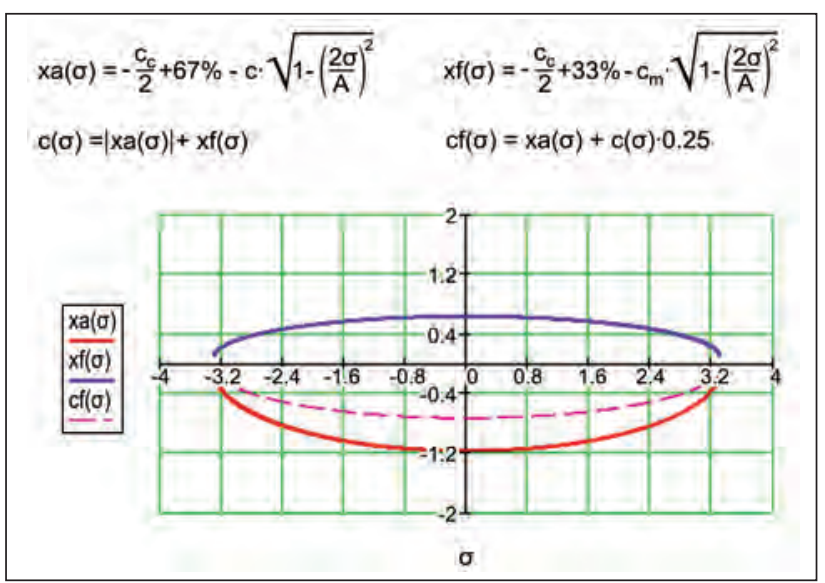

Fig. 2. Planform of the wing

\section{RESULTS AND DISCUSSION}

\section{CANOPY CONSTRUCTION:}

Generation of patterns and 3D model of the parachute Using the data obtained with Mathcad the input for the script made in Visual Basic [4-5], the drawing of three-dimensional model in AutoCAD "Model Space" is done automatically. This model is then discretized in its component parts then flattened to obtaining the construction 2D patterns, figures 3,4 and 5 .

After plotting the patterns and the marking of the significant elements (the points of attachment for the lines, marked with a red circle on the patterns) the cutting of the component elements is made. The sewing order is from the tip of the wing to the middle, the stitches being made on the inside of the cells [6].

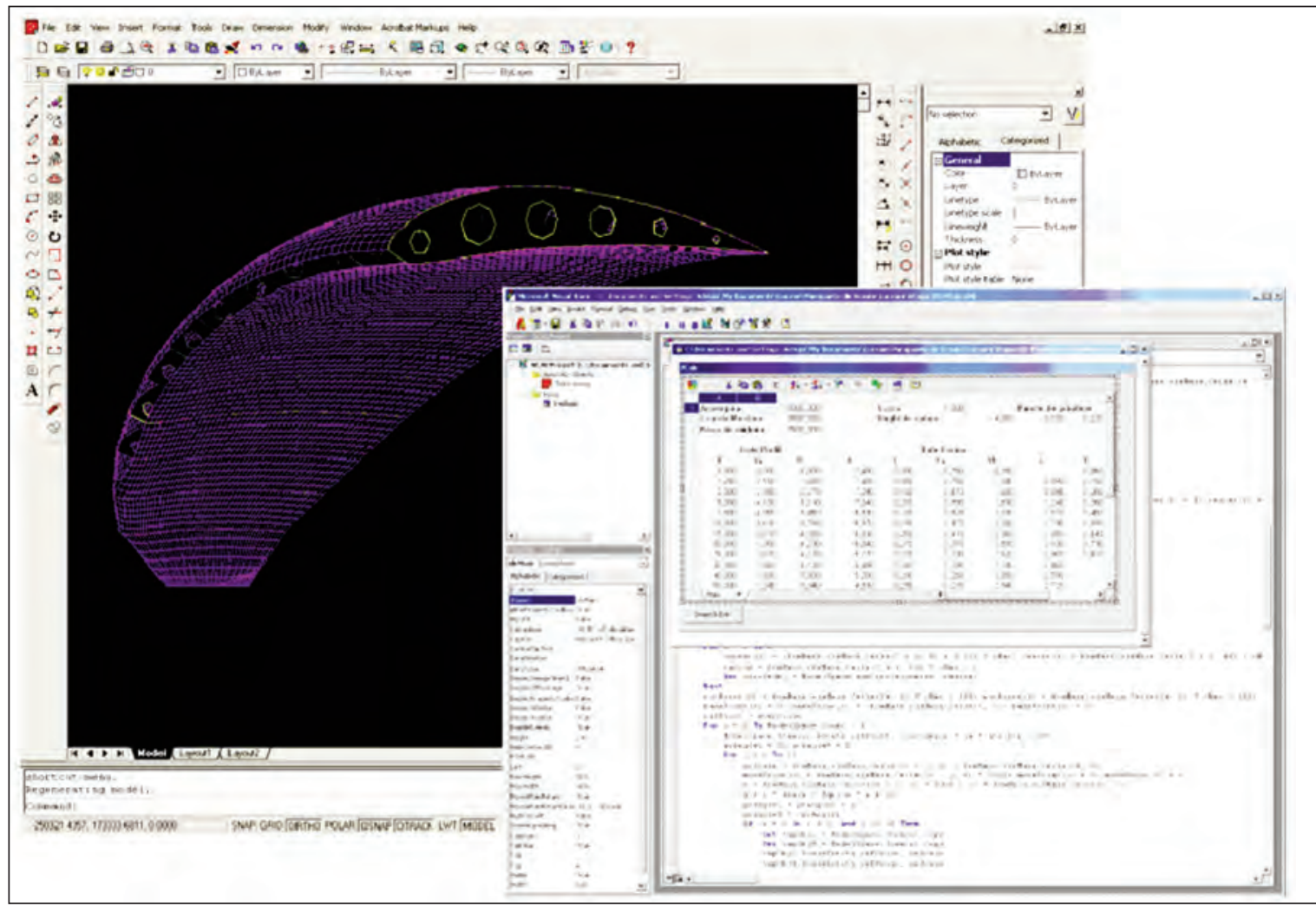

Fig. 3. Import and data alteration interface, source code (VB) pattern extraction and the generated 3D model

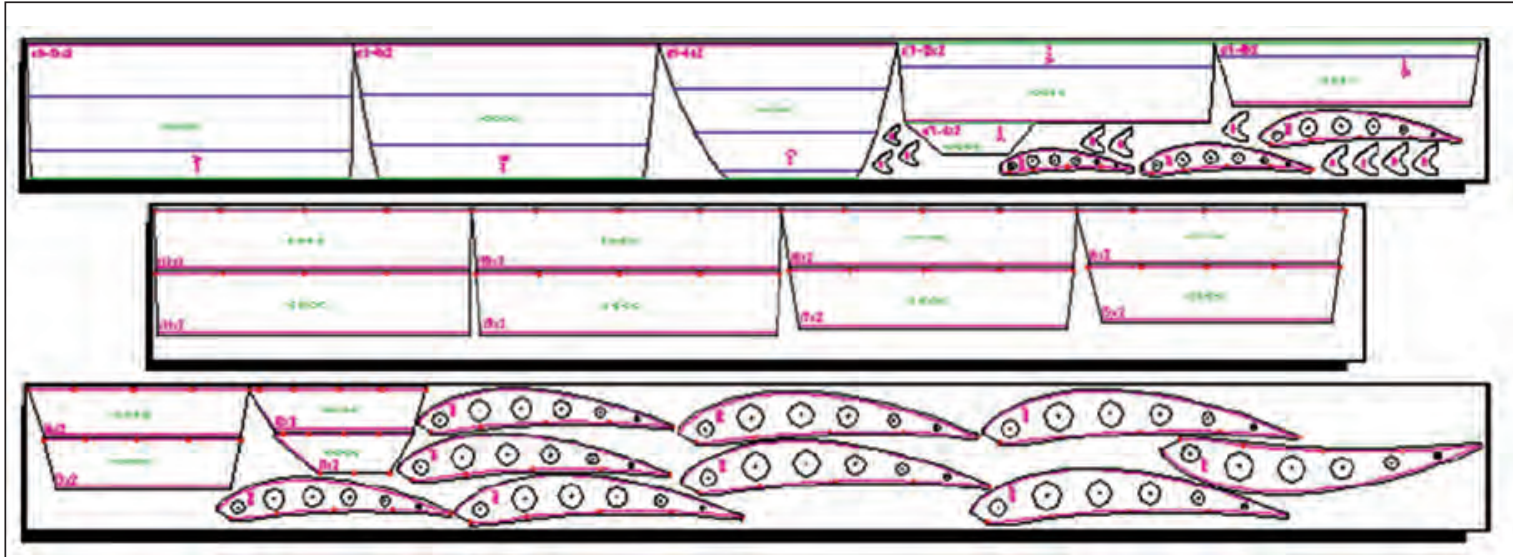

Fig. 4. Patterns extracted from the 3D model to be sent to the CAM cutter 


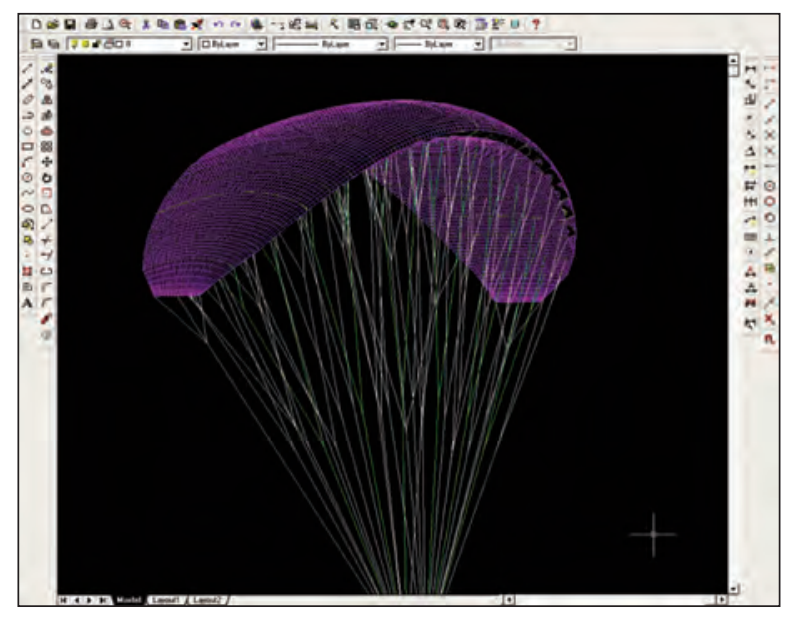

Fig. 5: Canopy assembly

Testing the experimental model is performed on free flight. The parachute was attached with a weight of $25 \mathrm{~kg}$ to simulate the maximum load. There are a series of 15 flights starting at moderate winds (4-6 m/s) (figure 6). Observation of flight behavior is made visually. The model was tested for validation of the final shape; in particular, the optimal curvature of the wing was sought [7]. In this respect tests were performed with different curves of the wing by modifying the length of the suspension lines. Measurement of inflation time was also observed. The inflation time was very good even in poor wind conditions.

\section{CONCLUSIONS}

In this paper a numerical method was used to generate the geometry for a ram-air parachute with optimization of performance and fabrication efficiency. The method calculates the performance parameters

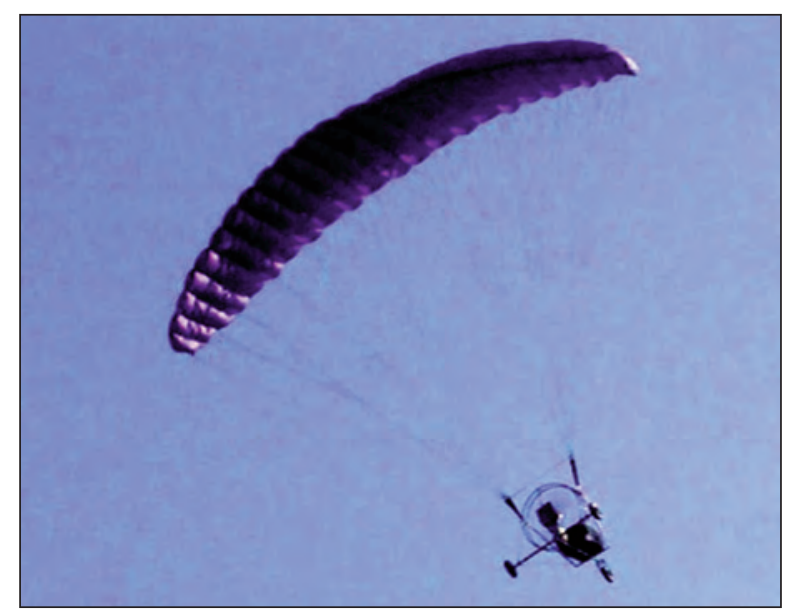

Fig. 6: Parachute in remote controlled flight

of the wing at different speeds and different angles of incidence and sliding to improve the design of ram-air parachutes for a great range of operating scenarios. The paper details in the particular case the design for an original type of scaled down ram-air parachute that has a very high aspect ratio and can be also be used as a glider wing, launched from the ground using a para-motor propeller assembly. Although the code can be used to develop any kind of ram-air parachute the presented case was used to factor in also the scaling capabilities of the code.

The original contribution is the development of the method for extracting the patterns from the 3D model in order to obtain high precision and low material consumption in the fabrication phase of the prototype.

The method in this paper could provide the basis for a larger design and optimization software framework for ram-air parachutes.

\section{BIBLIOGRAPHY}

[1] Riegels, F.W. Airfoils Sections, In: Butter Worts, London, 1961.

[2] Knacke, T.W. Parachute Recovery Systems. Design Manual, In: Para Publishing, Santa Barbara, California, 1992.

[3] Poynter, D. The Parachute Manual. A technical Treatise on Aerodynamic Decelerators, In: vol. I, Para Publishing, Santa Barbara, California, 1991.

[4] Salistean, A., Niculescu, C. Aparat de zbor din textile tehnice, In: Revista Industria textila, vol. 58, 2007, nr. 6, pp. $223-225$.

[5] Farama, D., Balan, S., Irovan, M., Tutunaru, I. Confort si performanta in sport, ISBN 978-973-730-335-6, Ed. Performantica, 2007.

[6] Poynter, D. The Parachute Manual. A technical Treatise on Aerodynamic Decelerators, In: vol. II, Para Publishing, Santa Barbara, California, 1991.

[7] Whittall, N. Paragliding. The complete guide, In: The Lyons Press, New York, 1995.

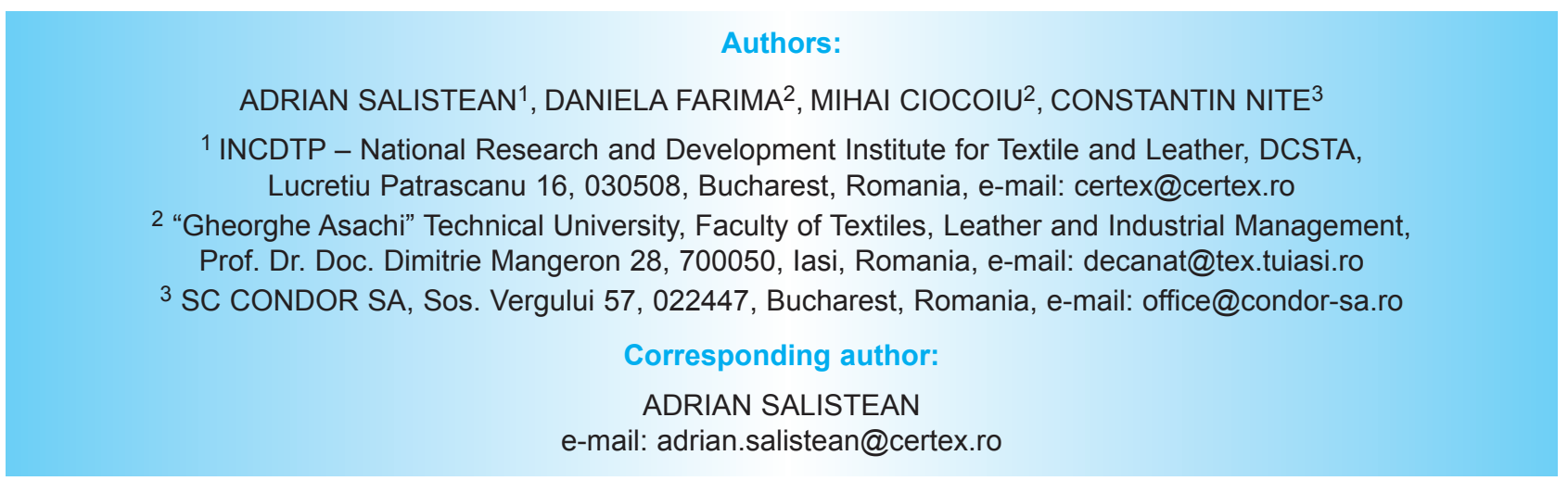




\title{
Effects of agglomeration externalities on total factor productivity: evidence from China's Textile Industry
}

DOI: 10.35530/IT.068.06.1408

\author{
HUA YUAN \\ JUNJIE ZHANG \\ YUN ZHANG
}

\author{
YAN HONG \\ HONGZHONG ZHAO
}

\section{REZUMAT - ABSTRACT}

\section{Efectele externalităților de aglomerare asupra productivității totale: exemple din industria textilă din China}

Lucrarea analizează liniaritatea impactului externalitătilor de aglomerare ale MAR, Jacobs și Porter asupra productivității totale (TFP) și a descompunerilor sale în cadrul industriei textile din China, prin utilizarea datelor despre întreprinderile textile din 29 de provincii, în perioada 2003-2014. Sistemul GMM este utilizat pentru estimare. Rezultatele arată că externalitățile MAR marchează eficiența tehnică prin trasarea eficienței tehnice pure și accelerarea progresului tehnologic. Externalitățile Jacobs măresc eficiența scării și progresul tehnic, dar scad eficiența tehnică pură. Externalitățile Porter scad eficiența pură și eficiența scării, impunând astfel un efect negativ atât asupra eficienței tehnice, cât și asupra progresului tehnic.

Cuvinte-cheie: aglomerare industrială, extrnalități de aglomerare, productivitate totală, indice Malmquist, sistem GMM

\section{Effects of agglomeration externalities on total factor productivity: evidence from China's Textile Industry}

The paper analyzes the linearity in the impact of agglomeration externalities of MAR, Jacobs, and Porter on total factor productivity (TFP) and its decompositions of the textile industry in China by using panel data of textile enterprises in 29 provinces from 2003 to 2014. System-GMM is utilized for estimation. Results show that MAR externalities enhance technical efficiency through pulling up pure technical efficiency and accelerate the progress of technology. Jacobs externalities increase scale efficiency and technical progress but decrease pure technical efficiency. Porter externalities lower pure and scale efficiency, hence imposing a negative effect on both technical efficiency and technical progress.

Keywords: industrial agglomeration; agglomeration externalities; total factor productivity; Malmquist index; System GMM

\section{INTRODUCTION AND LITERATURE REVIEW}

Industrial agglomeration brings about many externalities, including externalities of MAR, Jacobs, and Porter, the influence of which has been a popular research issue in recent years. Total factor productivity (TFP) can be taken as a measure of long-term technological change; its growth is affected by many exogenous factors. Agglomeration externalities enhance TFP through knowledge spillovers and they are important contributors to the growth of TFP. An investigation for the relationship between industrial agglomeration and TFP in Chinese textile industry is still rather weak, and there is little empirical research on the effect of agglomeration externalities on TFP growth and the channels through which the effect reaches TFP of the textile industry in China. Therefore, it is of great practical significance to study the relationship between them and the way by which agglomeration externalities enhance the technical efficiency and technical progress.

MAR externalities emerge when firms benefit from local specialization in their own industry through inter-firm exchanges of knowledge and information. Specialization facilitates this tacit knowledge propagating within the industry, and thus promotes the improvement of TFP. On the contrary, Jacobs externalities argue that industrial diversity in a region is more convenient for spreading of knowledge and ultimately stimulates TFP growth. Unlike the MAR and Jacobs externalities, Porter externalities derive from knowledge spillovers within a correlated industry, and competition in the vertically integrated industry stimulated innovative activities, which accelerates the rate of technical progress and TFP growth. Glaeser et al. [1] are pioneers on researching agglomeration externalities, since then, there are a number of theoretical and empirical researches on the effects of agglomeration externalities and productivity. However, whether this externality promotes TFP growth has been a hotly-debated subject in previous literatures. For the existence of heterogeneity and the method of measurement, the question on which kind of externalities are the most beneficial to TFP growth is rather complicated. Beaudryand Schiffauerova [2] analyzed 89 articles, which discussed the relationship between agglomeration externalities and economic growth through a statistical method. The results showed that about $71 \%$ of the samples supported the view that MAR externalities had a positive effect on TFP, and about $22 \%$ of the samples approved that Jacobs externalities were favorable for TFP growth. Only a small number of literature proved that Porter externalities brings benefits to TFP. Some studies support the argument that MAR externalities are beneficial for enhancement of TFP because of specialization [3, 4]. In contrast to the views mentioned above, some empirical studies drew different conclusions. Batisse[5] found Jacobs and Porter externalities were particularly favorable for efficiency. Partridge and Rickman [6] drew a similar conclusion, 
where it was suggested that Jacobs externalities were more important for productivity than MAR externalities in short-term and long-term. When considering heterogeneity, the findings were inconsistent. Some research results suggested that effect of agglomeration externalities varied with industries and regions [7, 8]. In addition, there are some studies examined the indirect effect of agglomeration externalities on TFP, such as through R\&D activities or FDI to promote TFP growth [9].

The structure of the article is as follows. Section 2 briefly introduces situation of agglomeration and TFP growth in China. Section 3 describes the variables and data and then reports estimates. Section 4 concludes the study with the indication of the limitations and further research direction of this research.

\section{THE AGGLOMERATION AND TFP IN CHINA}

Textile industry plays a critical role in terms of output, export and employment in China's manufacturing sector. China's textile industry has experienced roughly four stages, with the first stage in the 1950s to 1970 s when the textile industry was centralized in Beijing, Shandong, and Shanghai. Due to a weak

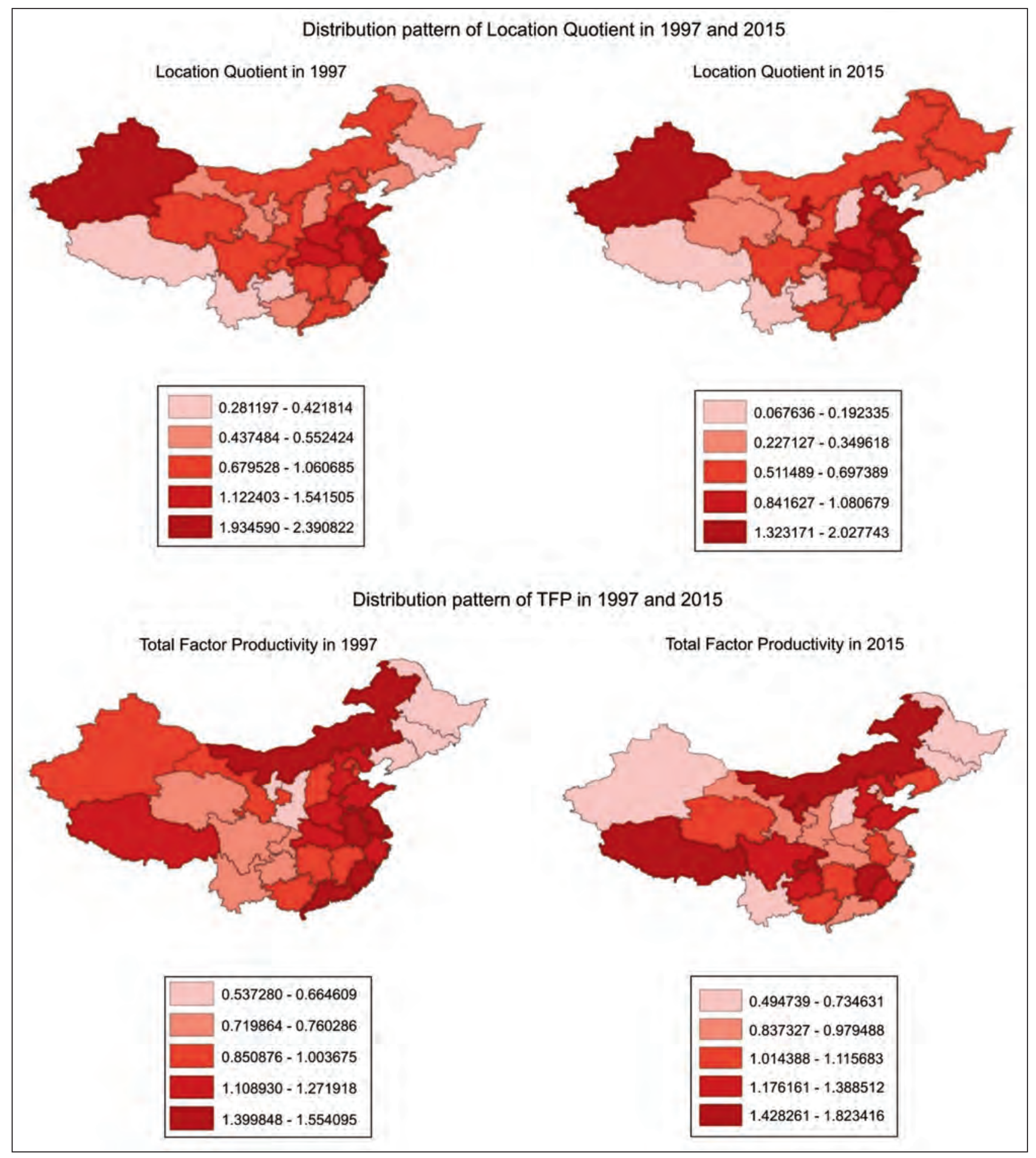

Fig. 1. Distribution pattern of Location Quotient and TFP in 1997 and 2015 Source: analysis of data provided by the China Textile Industry Development Report 
industrial base, coupled with the implementation of policies in a centralized planned economic system, during this period, the government invested heavily in textile enterprises in these areas. The second stage was from the 1970s to 1990s, after the reform and opening up policy, many textile enterprises chose locations close to consumers and labor markets in order to reduce the cost and obtain comparative advantages; therefore, textile enterprises gathered in Guangdong, Fujian and other areas along the Southeast Coast. The 1990s to 2005 was the third stage. In 1998, China's textile industry faced the problems of excess productive capacities, insufficient supply of raw materials and difficulty selling its products. To solve these problems, the capacity reduction policies were implemented. Then there were five large industrial clusters formed in Zhejiang, Jiangsu, Guangdong, Shandong, and Shanghai. Fourth stage was 2006 until now. With the cancellation of textile quota and rising land rents in coastal areas, the textile industry began to diffuse from Zhejiang, Jiangsu, and Guangdong to Jiangxi, Henan, Liaoning, Hubei, Hunan, Anhui, Sichuan, Hebei and other central and western regions. Taking Jiangxi as an example, industrial added value growth of the textile industry increased 1.3 times from 2009 to 2012.

Figure 1 shows the change of Location Quotient (LQ) of the textile industry from 1997 to 2015 . Agglomeration pattern shows that since the1990s, the textile industry has shown a trend of changing from concentration to diffusion. Centralized regions have transferred from southeast coastal regions to central and western regions. In addition, it is worth noting that a region, such as Xinjiang, which is close to international market, also has a high LQ. Mean while, figure 1 demonstrated TFP in central and western regions, such as Inner Mongolia, Ningxia, Jiangxi, and Chongqing, has been increasing year by year.

There are some kinds of connections between TFP and $L Q$, but this relationship is not obvious. After further correlation analysis, the result displays that there is a significant correlation at 0.05 levels (bilateral) between the rates of change of TFP and $L Q$, with a correlation coefficient of 0.407 . In other words, the externalities of industrial agglomeration do have a significant impact on TFP changes.

\section{EMPIRICAL STRATEGY}

\section{Model and hypothesis}

Based on the literature analysis, this paper will consider three dimensions, which are respectively industry, time and geography. In this way, we will study the effect of agglomeration externalities on TFP. Externalities of industry dimension include specialization, diversification, and competition. Time dimension analyzes the externalities from the dynamic point of view, and the geographical dimension is analyzes the aspects of location. Firstly, by reference to Griliches and Jaffe's approach [10, 11], agglomeration externalities are introduced into the production function. Assuming that the production function is in the form of Cobb-Douglas function, there is a technical knowledge input $S$ in addition to the inputs of capital and the labor, whose function expression is:

$$
Y=A K^{\alpha} L^{\beta} S^{\delta}
$$

The expression for the total factor productivity is:

$$
T F P=\frac{Y}{K^{\alpha} L^{\beta}}=A S^{\delta}
$$

Since the technical knowledge is influenced by MAR, Jacobs, and Porter externalities, can be written as a function of three externalities, i.e.:

$$
S^{\delta}=F(\text { mar, jac, por })
$$

This study is based on the hypothesis that there is a linear relationship between agglomeration externalities, time factor tand the regional factor i, then eq. (2) can be written as:

$$
T F P_{i, t}=A_{i, t} \times\left(\operatorname{mar}_{i, t}\right)^{\varphi_{1}} \times\left(\mathrm{jac}_{i, t}\right)^{\varphi_{2}} \times\left(\text { por }_{i, t}\right)^{\varphi_{3}}
$$

And the changing rate of TFP in region $i$ is:

$$
\operatorname{TFPC}_{i, t}=A C_{i, t} \times M A R C_{i, t}^{\rho_{1}} \times J A C C_{i, t}^{\rho_{2}} \times P O R C_{i, t}^{\rho_{3}}
$$

On both sides of the logarithm, eq. (5) can be written as follows:

$$
\begin{aligned}
\ln \text { TFPC }_{i, t} & =\ln A C_{i, t}+\rho_{1} \ln \text { MARC }_{i, t}+ \\
& +\rho_{2} \ln \operatorname{JACC}_{i, t}+\rho_{3} \ln \text { PORC }_{i, t}
\end{aligned}
$$

From "time dimension" aspect, lag of TFP is added into the equation, and the geographical factors are put into the equation as dummy variables, then the eq. (6) can be changed into:

$$
\begin{aligned}
& \operatorname{In} \text { TFPC }_{i, t}=\ln A C_{i, t}+\sigma_{1} \ln \text { TFPC }_{i, t-2}+\sigma_{2} \ln \text { TFPC }_{i, t-1}+ \\
& \quad+\rho_{1} \ln M_{A R C_{i, t}}+\rho_{2} \ln \operatorname{JACC}_{i, t}+\rho_{3} \ln \text { PORC }_{i, t}+ \\
& +\omega_{1} D U M_{E}+\omega_{2} D U M_{M}+\varepsilon_{i, t}
\end{aligned}
$$

Herein: $\operatorname{TFPC}_{i, t}$ is a changing rate of TFP in region $i$ from time $t$ to $t+1$. TFPC $i, t-2, T F P_{i, t-1}$ are lag variables of TFP. $M A R C_{i, t}$ indicates the changes in degree of specialization of region $i . J_{A C C_{i, t}}$ represents the changes in the degree of diversity in region $i, P O R C_{i, t}$ implies the level of competition in region $i, A C_{i, t}$ is a constant term, $D U M_{E}, D U M_{M}$ are the region dummy variables for the eastern and middle regions, $\varepsilon_{i, t}$ is a random error term, and $i$ and $t$ respectively indicate the region and time.

In order to understand the way by which agglomeration externalities affects change rate of TFP, we decompose TFP into two parts: technical efficiency change (EFC) and technological progress change (TEC). Then technical efficiency change is divided into pure technical efficiency change (PEC) and scale efficiency change (SEC), based on the eq. (7). The metrological expression of the agglomeration externalities and TFP decompositions can be constructed as follows: 


$$
\begin{gathered}
\ln C_{i, t}=\operatorname{CON}+\lambda_{1} \ln C_{i, t-2}+\lambda_{2} \ln C_{i, t-1}+ \\
+\gamma_{1} \ln M_{A R C_{i, t}}+\gamma_{2} \ln J_{A C C_{i, t}}+\gamma_{3} \ln P_{\text {ORC }}+ \\
+\psi_{1} D U M_{E}+\psi_{2} D U M_{M}+\varepsilon_{i, t} \\
C \in\{E F C, \text { TEC, PEC, SEC }\}
\end{gathered}
$$

\section{Variables and data descriptions}

\section{Calculation of dependent variables}

According to the method proposed by Cave et al. [12] and Fare et al. [13], Malmquist index is used for calculating the change rate of TFP. In addition, TFP change (TFPC) can be decomposed into technical efficiency change (EFC) and technical progress change (TEC):

$$
\begin{gathered}
M_{O}\left(y^{t+1}, x^{t+1}, y^{t}, x^{t}\right)=\frac{D_{0}^{t+1}\left(x^{t+1}, y^{t+1}\right)}{D_{0}^{t}\left(x^{t}, y^{t}\right)} \times \\
\times\left[\frac{D_{0}^{t}\left(x^{t+1}, y^{t+1}\right)}{D_{0}^{t+1}\left(x^{t+1}, y^{t+1}\right)} \times \frac{D_{0}^{t}\left(x^{t}, y^{t}\right)}{D_{0}^{t+1}\left(x^{t}, y^{t}\right)}\right]^{1 / 2}=E F C \times T E C
\end{gathered}
$$

EFC evaluates the ability in resource utilization efficiency from $t$ to $t+1$; TEC measures the movement of the technical frontier, indicating the progress of technology and innovation between the two periods. By utilizing both CRS and VRS frontiers to estimate the distance functions in eq. (9) technical efficiency change (EFC) can be further divided into pure technical efficiency change (PEC) and scale efficiency change (SEC) as follows:

$$
\begin{aligned}
E F C & =\frac{D_{0, V R S}^{t+1}\left(x^{t+1}, y^{t+1}\right)}{D_{0, V R S}^{t}\left(x^{t}, y^{t}\right)} \times \\
& \times\left[\frac{D_{0, C R S}^{t+1}\left(x^{t+1}, y^{t+1}\right) / D_{0, V R S}^{t+1}\left(x^{t+1}, y^{t+1}\right)}{D_{0, C R S}^{t+1}\left(x^{t}, y^{t}\right) / D_{0, V R S}^{t+1}\left(x^{t}, y^{t}\right)} \times\right. \\
& \left.\times \frac{D_{0, C R S}^{t}\left(x^{t+1}, y^{t+1}\right) / D_{0, V R S}^{t}\left(x^{t+1}, y^{t+1}\right)}{D_{0, C R S}^{t}\left(x^{t}, y^{t}\right) / D_{0, V R S}^{t}\left(x^{t}, y^{t}\right)}\right]^{1 / 2}= \\
& =P E C \times S E C
\end{aligned}
$$

PEC describes the change of technical efficiency under variable scale returns; SEC represents the distance between the actual scale and the optimal scale of production.

\section{Description of independent variables}

In this paper, MAR externalities refer to knowledge spillovers of specialization within the textile industry. The specialization level of the textile industry is measured by the LQ, with specific formula written as:

$$
\operatorname{mar}_{i}=\frac{L_{i, t e x} / L_{i, m}}{\sum_{i}^{j} L_{t e x} / \Sigma_{i}^{j} L_{m}}
$$

Where $L_{i, t e x}$ is the number of workforce of textile industry in province $i, L_{i, m}$ represents the total number of employment in the manufacturing sector of province $i, L_{t e x}$ is the sum of the number of employment in textile industries from the region $i$ to $j, L_{m}$ is total number of employment of manufacturing sector nationwide.

Jacobs externalities are the knowledge spillovers from diversification of all industries in a region. On the basis of measurement methods proposed by Frenken, Koen, et al. [14], Shannon-Weiner index is applied to calculate the level of diversification. The Shannon-Weiner index is defined as:

$$
j a c_{i}=-\sum_{m=1}^{k} p_{m} \log _{2} p_{m}
$$

$p_{m}$ is the proportion of the number of employment in $m$ industry to the total number of employment in region $i ; k$ represents the type of industry. This paper selects 19 industries in each province for calculation. The relative density of enterprises is selected for measurement of the Porter externalities, and the calculation function is:

$$
\text { por }_{i}=\frac{F_{i} / A C R E_{i}}{\sum F_{i} / \sum A C R E_{i}}
$$

$F_{i}$ represents the number of enterprises in region $i$, $A C R E_{i}$ is acreage of region $i$.

The change rate of three externalities respectively is:

$$
\begin{aligned}
M_{A R C} & =\frac{\operatorname{mar}_{i, t+1}}{\operatorname{mar}_{i, t}} \quad J A C C_{i, t}=\frac{j a c_{i, t+1}}{j a c_{i, t}} \\
\text { PORC }_{i, t} & =\frac{\text { por }_{i, t+1}}{\text { por }_{i, t}}
\end{aligned}
$$

In this paper, above designated size enterprises of the textile industry in 29 provinces of China from 2003 to 2014 are used as samples for estimation. Herein, before 2011, "above designated size" textile enterprises refers to the enterprises with main business income over 500 million Yuan. After 2011, enterprises whose main business income over 20 million Yuan are the above designated size enterprises. The main reason for choosing these enterprises lies in that they have a leading status in the market and relatively large scale. Consequently, the collected data maintains its integrity and continuity due to the fact that these enterprises have to submit their annual reports in the same format.

\section{Results analysis}

\section{Analysis of TFP changes}

According to the method mentioned above, TFP and its decompositions are calculated by utilizing Data Envelopment Analysis (DEA) and the results are shown in figure 2.

Figure 2 shows that the growth rate of TFP was high in 2005; this growth was mainly originated from the domestic and foreign market. In terms of the domestic market, the total retail sales of social consumption increased $12.9 \%$, and the output value of textile enterprises simultaneously increased by $26.09 \%$. As for the foreign market, total trade volume of textile was $\$ 136.434$ billion, and trade surplus reached to $\$ 1004.36$ billion, accounting for $98.58 \%$ of China's 


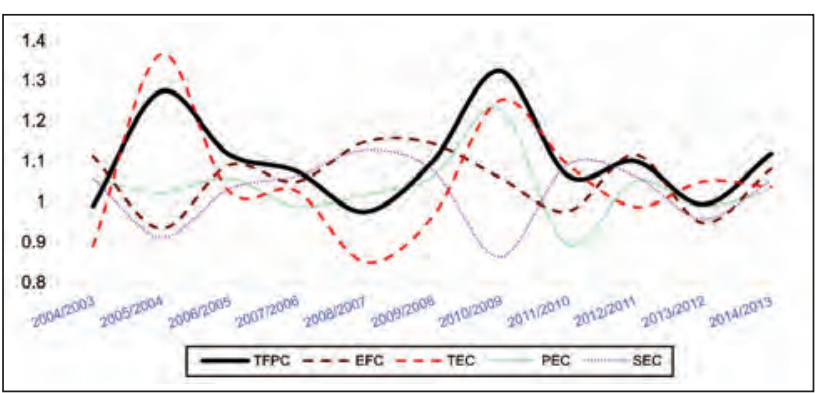

Fig. 2. Total factor productivity changes and its compositions from 2003 to 2014 Source: own research

trade surplus. Driven by these two factors, TFP grew to approximately $30 \%$. TFP growth in 2010 increased by $32.5 \%$, which was mainly originated from governmental policy that expanded domestic demand in 2009 in order to fight against financial crisis. In contrast, TFP decreased by $2.5 \%$ in 2008 , due to a depreciation of $\mathrm{RMB}$, rising costs of production and international financial crisis. In 2013, TFP also reduced by $0.7 \%$, mainly because of insufficient demand of the international market, rapidly increasing financial costs and land rents, coupled with the domestic cotton management policy that caused a rise in cotton prices.

Figure 2 also demonstrates the tendency of decompositions of TFP based on eq. (9) and eq. (10), where EFC is not exactly the same as TEC. TFPC and TEC show the same trend before 2012. That is, TFP growth originated from technical progress before 2012; however, after that year, technical efficiency enhanced TFP growth. TEC was affected by scale efficiency prior to 2011, while the impacts of PEC and SEC on EFC are more complex after 2011.

\section{Analysis of regression results}

Considering heteroskedasticity and autocorrelation of panel data, before the regression, unit root test, heteroskedasticity and autocorrelation tests are carried out. The test results show that the data is stable, but the cross-sectional heteroskedasticity and serial correlation are present. So this paper uses system GMM method proposed by Arellano, Bover, Bond et al. $[15,16]$. The results are shown in table 1.

The regression results illustrated that:

- TFP of the textile industry is negatively correlated with changes in the previous stage, and the firstorder lag of TFPC, compared with the second-order lag, has a greater effect. The two decompositions, EFC and TEC, also showed the same trend. This tendency is also found in analyzing PEC and SEC. The regression results indicate that change rate of TFP of China's textile industry is related to the growth rate in the early stage, and if TFP and its decompositions have a substantial increase in the early period, the current growth rate will decline. These results are consistent with the reality of China.

- Three agglomeration externalities have different effects on the change rate of TFP. MAR externalities promote the change rate of TFP, while Jacobs and
Porter externalities are unfavorable to the growth of TFP. These results are similar to Hendson [17] and Martin [18], but not exactly the same. MAR externalities, statistically significant, enhances efficiency and technical progress, especially in the acceleration of technical progress; Jacobs externalities do not stimulate the growth of efficiency but can encourage the advancement of technical progress; and Porter externalities do not contribute to efficiency and technical progress. Furthermore, MAR externalities are beneficial to pure technical efficiency and reduce scale efficiency of the firm because the knowledge spillovers in the same industry can help companies save the costs of acquiring knowledge; meanwhile, specialization limits the size of the enterprise so that the scale efficiency declines. The hinder effect of Jacobs externalities on pure technical efficiency is statistically significant. In other words, spillovers of knowledge between industries in one region do not lead to the impetus of efficiency, but they are favorable for scale efficiency. However, this positive effect is not obvious; Porter externalities are detrimental to the promotion of pure efficiency and scale efficiency, which may be due to disorderly competition, which otherwise has a strong positive influence on scale efficiency.

- Table 1 also reflects that, after considering regional factors, coefficients of DUM_M are negative, indicating that the performance of these externalities in the middle of China is relatively low compared to eastern and western regions. That means the impact of agglomeration externalities is less effective in the central regions, such as Hunan, Jiangxi, Hubei, and Anhui; however, these are crucial places of origin for cotton and linen, and this phenomenon is worth continuing to study.

\section{CONCLUSION}

This paper analyzes the effect of industrial agglomeration externalities on TFP and its decompositions of China's textile industry by using the panel data of 29 provinces from 2003 to 2014 . The results indicate that the growth rate of TFP in western China is higher than that in eastern coastal areas due to rising cost of production and industrial policy that transfers the textile industry from the eastern coastal region to the western region. The effect of agglomeration externalities on TFP is complex. The way for MAR externalities to facilitate the improvement of TFP is to enhance technical efficiency through pulling up pure technical efficiency and accelerating progress of technology. On the contrary, Porter externalities lower pure and scale efficiency, hence imposing a negative effect on both technical efficiency and technical progress, which ultimately reduces the growth rate of TFP. Jacobs externalities facilitate increase of scale efficiency and technical progress, but impede rising of pure technical efficiency. Therefore, the positive influence on TFP is not obvious. 


\begin{tabular}{|c|c|c|c|c|c|}
\hline \multirow[b]{2}{*}{ VARIABLES } & (1) & (2) & (3) & (4) & (5) \\
\hline & InTFPC & InEFC & InTEC & InPEC & InSEC \\
\hline \multirow{2}{*}{ InMARC } & 0.105 & 0.0340 & $0.168^{\star}$ & 0.109 & $-0.164^{*}$ \\
\hline & $(0.115)$ & $(0.110)$ & $(0.0876)$ & $(0.106)$ & $(0.0894)$ \\
\hline \multirow{2}{*}{ InJACC } & -0.160 & -0.371 & 0.156 & $-0.464^{* *}$ & 0.236 \\
\hline & $(0.258)$ & $(0.249)$ & $(0.154)$ & $(0.189)$ & $(0.248)$ \\
\hline \multirow{2}{*}{ InPORC } & -0.0982 & $-0.230^{\star *}$ & -0.0129 & -0.0838 & -0.124 \\
\hline & $(0.111)$ & $(0.108)$ & $(0.0649)$ & $(0.139)$ & $(0.140)$ \\
\hline \multirow{2}{*}{ DUM_E } & 0.111 & 0.198 & 0.0475 & -0.0826 & 0.338 \\
\hline & $(0.196)$ & $(0.234)$ & $(0.127)$ & $(0.128)$ & $(0.478)$ \\
\hline \multirow[b]{2}{*}{ DUM_M } & -0.391 & -0.361 & -0.120 & $-0.337^{* *}$ & -0.836 \\
\hline & $(0.279)$ & $(0.273)$ & $(0.182)$ & $(0.148)$ & $(0.559)$ \\
\hline L.InTFPC & $\begin{array}{r}-0.478^{* * *} \\
(0.0371)\end{array}$ & \multirow{14}{*}{$\begin{array}{c}-0.413^{* * *} \\
(0.0809) \\
-0.0602 \\
(0.0972)\end{array}$} & \multirow{14}{*}{$\begin{array}{c}-0.149^{*} \\
(0.0816) \\
-0.208^{\star * *} \\
(0.0536)\end{array}$} & \multirow{14}{*}{$\begin{array}{c}-0.559^{* * *} \\
(0.137) \\
-0.149 \\
(0.105)\end{array}$} & \\
\hline & $\begin{array}{l}-0.158^{\star *} \\
(0.0678)\end{array}$ & & & & \\
\hline 1 & & & & & \\
\hline L.InEFC & & & & & \\
\hline L2.InEFC & & & & & \\
\hline & & & & & \\
\hline L.InTEC & & & & & \\
\hline L2.InTEC & & & & & \\
\hline \multirow{2}{*}{ L.InPEC } & & & & & \\
\hline & & & & & \\
\hline \multirow{4}{*}{$\begin{array}{l}\text { L2.InPEC } \\
\text { L.InSEC } \\
\text { L2.InSEC }\end{array}$} & & & & & \\
\hline & & & & & $-0328^{*}$ \\
\hline & & & & & $(0.176)$ \\
\hline & & & & & $-0.184^{* *}$ \\
\hline \multirow[b]{2}{*}{ Constant } & $0.226^{* *}$ & 0.125 & 0.0613 & $0.169^{* * *}$ & $\frac{(0.0811)}{0.157^{*}}$ \\
\hline & $(0.108)$ & $(0.0936)$ & $(0.0531)$ & $(0.0510)$ & $(0.0842)$ \\
\hline Observations & 261 & 261 & 261 & 261 & 261 \\
\hline Number of firm & 29 & 29 & 29 & 29 & 29 \\
\hline $\begin{array}{l}\text { Arellano-Bond test for } \\
\operatorname{AR}(2)(p r>z)\end{array}$ & 0.981 & 0.770 & 0.419 & 0.908 & 0.740 \\
\hline $\begin{array}{l}\text { Hansen test of overid. } \\
\text { (prob>chi2) }\end{array}$ & 0.160 & 0.209 & 0.116 & 0.193 & 0.134 \\
\hline Wald chi2 & 277.16 & 85.01 & 21.39 & 60.82 & 55.97 \\
\hline
\end{tabular}

Standard errors in parentheses: ${ }^{* * *} p<0.01,{ }^{* *} p<0.05,{ }^{*} p<0.1$

The location has little effect on the three externalities except for pure technical efficiency.

Conclusions can be drawn as follows: At present, enhancement of TFP of China's textile industry is more dependent on MAR externalities, namely specialization. Specialization promotes the efficiency and technical progress through the diffusion of tacit and technical knowledge, thus contributing to the growth of TFP. Jacobs externalities have insufficient impact on the textile industry. However, Porter externalities hamper the development of TFP.

There are some limits of this research: (1) we only selected data with designated size of Chinese textile enterprises as samples, (2) this paper only studied the effects of agglomeration externalities on TFP, and (3) the reason for impediment of Porter externalities on TFP were not discussed intensively due to the context limit. Further work will focus on these limits. 


\section{BIBLIOGRAPHY}

[1] Glaeser, E.L., Kallal, H.D., Scheinkman, J.A. et al., Growth in cities, In: Journal of Political Economy, 1992, vol. 100, no. Volume 100, Number 6, pp. 1126-1152.

[2] Beaudry, C., and Schiffauerova, A., Who's right, Marshall or Jacobs? The localization versus urbanization debate, In: Research Policy, 2009, vol. 38, no. 2, pp. 318-337.

[3] Escriba-Perez, F.J., and Murgui-Garcia, M.J., Time varying agglomeration effects on total factor productivity in Spanish regions (1995-2008), In: Regional \& Sectoral Economic Studies, 2014, vol. 14, no. 2, pp. 75-90.

[4] Widodo, W., Salim, R., and Bloch, H. Agglomeration economies and productivity growth in manufacturing industry: Empirical evidence from Indonesia, In: Economic Record, 2014, vol. 90, no. Supplement, pp. 41-58.

[5] Batisse, C. Dynamic externalities and local growth: A panel data analysis applied to Chinese provinces, In: China Economic Review, 2002, vol. 13, no. 2-3, pp. 231-251.

[6] Partridge, C., and Dan, S.R., Static and dynamic externalities, industry composition, and state labor productivity: A panel study of states, In: Southern Economic Journal, 1999, vol. 66, no. 2, pp. 319-335.

[7] Lee, B.S., Sosin, K., and Hong, S.H. Sectoral manufacturing productivity growth in Korean regions, In: Urban Studies, 2005, vol. 42, no. 42, pp. 1201-1219.

[8] Agovino, M., and Rapposelli, A. Agglomeration externalities and technical efficiency in Italian regions, In: Quality \& Quantity, 2015, vol. 49, no. 5, pp. 1-20.

[9] Florescu, M.S., and Ivanov, F. Globalization as a factor of influence on the R\&D activity and the case of the textile industry in Romania, In: Industria Textila, 2016, vol. 67, no. 5, pp. 345-350.

[10] Griliches, Z. Issues in Assessing the contribution of research and development to productivity growth, In: Bell Journal of Economics, 1979, vol. 10, no. 1, pp. 92-116.

[11] Jaffe, A.B. Real effects of academic research, In: American Economic Review, 1989, vol. 79, no. 5, pp. $957-970$.

[12] Caves, D.W., Christensen, L.R., and Diewert, W.E. The economic theory of index numbers and the measurement of input, output, and productivity, In: Econometrica, 1982, vol. 50, no. 6, pp. 1393-1414.

[13] Färe, R., and Grosskopf, S. Malmquist productivity indexes and Fisher ideal indexes, In: Economic Journal, 1992, vol. 102, no. 410, pp. 158-160.

[14] Frenken, K., Van Oort, F.G., Verburg T. et al., Variety and regional economic growth in the Netherlands, In: Ssrn Electronic Journal, 2004, vol. 144, no. 2, pp. 179-80.

[15] Arellano, M., and Bover, O., Another look at instrumental variable estimation of error component models, In: Journal of Econometrics, 1990, vol. 68, no. 1, pp. 29-51.

[16] Blundell, R., and Bond, S. Initial conditions and moment restrictions in dynamic panel data models, In: Journal of Econometrics, 1998, vol. 87, no. 1, pp. 115-143.

[17] Henderson, J.V. Marshall's scale economies, In: Journal of Urban Economics, 2003, vol. 53, no. 1, pp. 1-28.

[18] Martin, P., Mayer, T., and Mayneris, F. Spatial concentration and plant-level productivity in France, In: Journal of Urban Economics, 2011, vol. 69, no. 2, pp. 182-195.

\section{Authors:}

HUA YUAN ${ }^{1}$, JUNJIE ZHANG ${ }^{2}$, YUN ZHANG ${ }^{3}$, YAN HONG ${ }^{4}$, HONGZHONG ZHAO $^{1}$

${ }^{1}$ Wuhan University of Technology, School of economics Hongshan District, Luo Shi Road, No. 122, 430070, Wuhan, China e-mail: kimiyuan@163.com

${ }^{2}$ Wuhan Textile University, Department of Mathematics and Computer 430000, Wuhan, China e-mail: 2007086@wtu.edu.cn

${ }^{3}$ Wuhan Donghu University, School of Economics Jiangxia District, Wenhua Road 301, 430212, Wuhan, China e-mail: 2280727@qq.com

${ }^{4}$ Soochow University, College of Textile and Clothing Engineering 215012, Suzhou, China e-mail: yannichonghk@gmail.com

Corresponding author:

JUNJIE ZHANG

e-mail:2007086@wtu.edu.cn 